
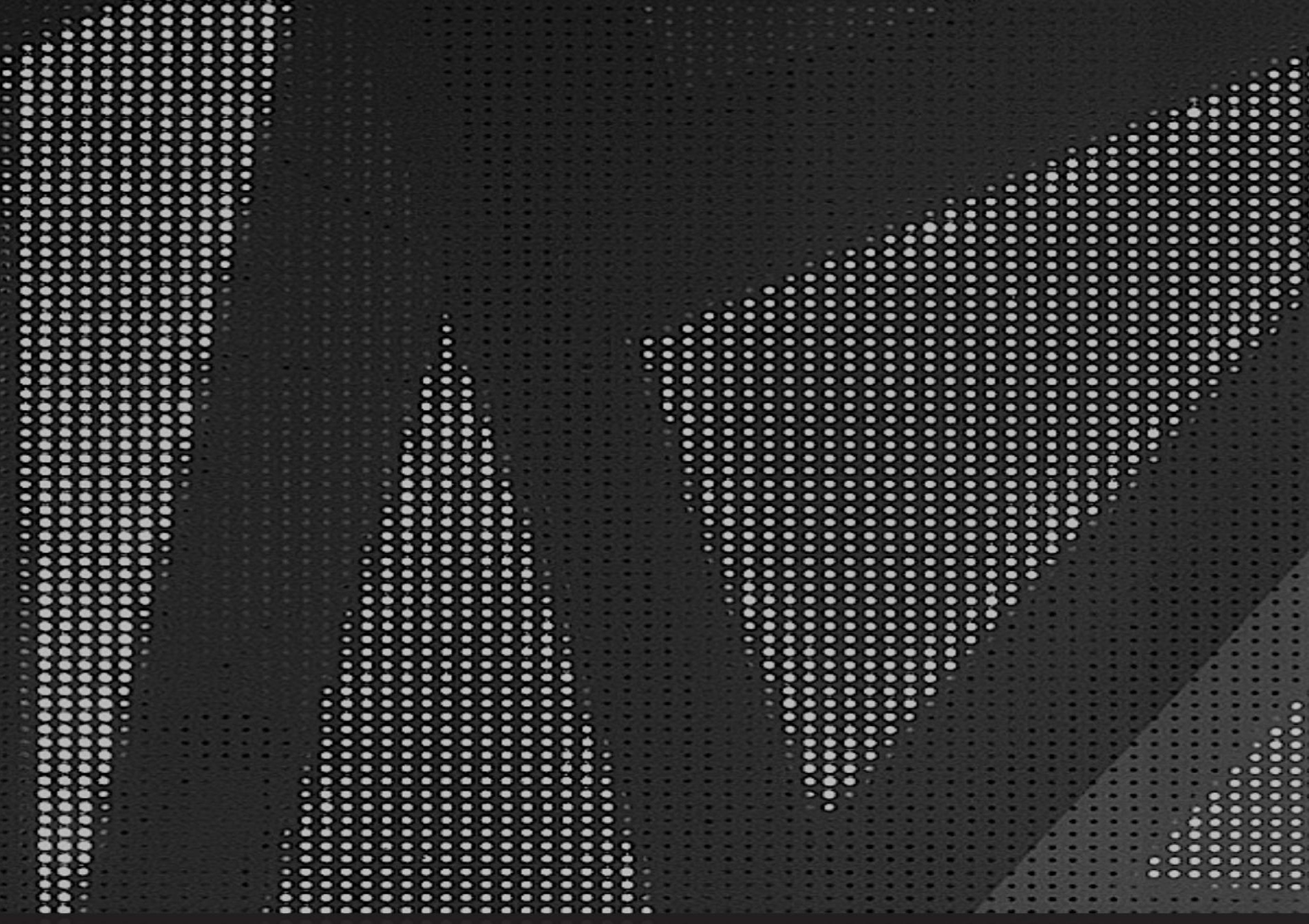

\title{
ARQUITETURA INTERATIVA contextos, fundamentos e design
}

Gabriela Pereira Carneiro

Tese de Doutorado | FAU-USP | São Paulo | 2014

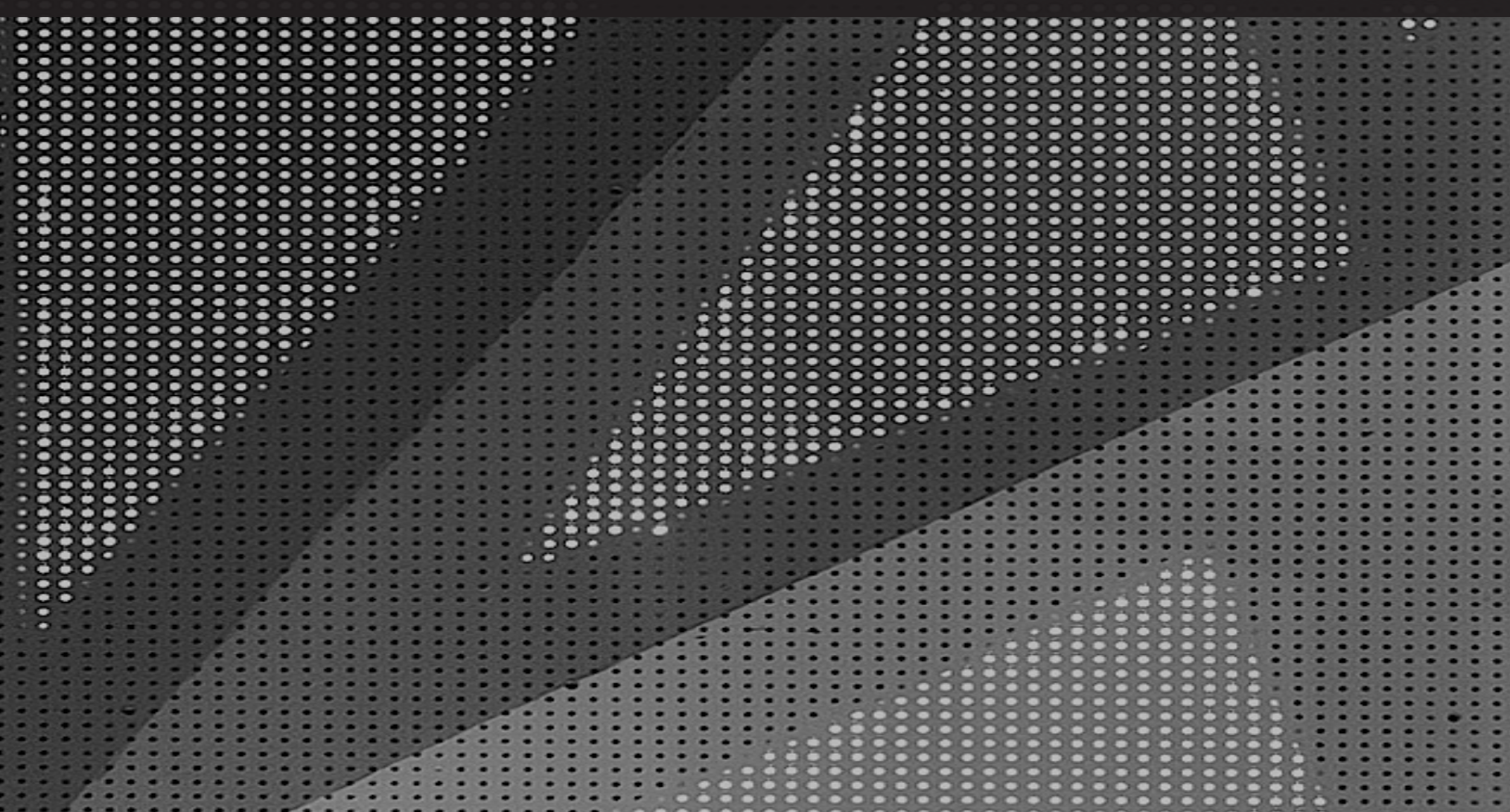




\section{Gabriela Pereira Carneiro}

\section{Arquitetura Interativa: contextos, fundamentos e design}

Tese apresentada a Faculdade de Arquitetura e Urbanismo da Universidade de São Paulo para obtenção do título de Doutor em Arquitetura e Urbanismo.

Área de Concentração: Design e Arquitetura Orientador: Prof. Dr. Carlos Zibel Costa

São Paulo / 2014 
AUTORIZO A REPRODUÇÃO E DIVULGAÇÃO TOTAL OU PARCIAL DESTE TRABALHO, POR QUALQUER MEIO CONVENCIONAL OU ELETRÔNICO, PARA FINS DE ESTUDO E PESQUISA, DESDE QUE CITADA A FONTE.

E-MAIL DA AUTORA: gabicarneiro@gmail.com

Carneiro, Gabriela Pereira

C289a Arquitetura interativa: contextos, fundamentos e design /

Gabriela Pereira Carneiro. --São Paulo, 2014.

235 p. : il.

Tese (Doutorado - Área de Concentração: Design e Arquitetura) FAUUSP.

Orientador: Carlos Zibel Costa

1.Arquitetura experimental 2.Design 3.Projeto de arquitetura 4.Tecnologia digital 5.Eletrônica embarcada 6.Design de interação 7.Computação ubíqua 8.Arquitetura interativa I.Título

CDU 72 


\section{Folha de Aprovação}

Nome: CARNEIRO, Gabriela Pereira

Título: Arquitetura Interativa: contextos, fundamentos e design

Tese apresentada a Faculdade de Arquitetura e Urbanismo da Universidade de São Paulo para obtenção do título de Doutor em Arquitetura e Urbanismo.

Aprovado em:

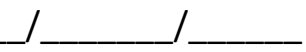

\section{Banca Examinadora}

Prof. Dr. Instituição:

Julgamento: Assinatura:

Prof. Dr. Instituição:

Julgamento: Assinatura:

Prof. Dr. Instituição:

Julgamento: Assinatura:

Prof. Dr. Instituição: 
Para Renato, pelo apoio incondicional 


\section{Agradecimentos:}

Este trabalho não teria sido possível, sem alguma pessoas que cruzaram o meu caminho. Em primeiro lugar, agradeço ao Prof. Zibel, por ter acreditado e confiado no pontencial desta pesquisa, e na minha capacidade de realizá-lo. Também foi essencial o financiamento da FAPESP, sem o qual não seria possível a dedicação integral ao trabalho.

O diálogo com colegas pesquisadores e professores do LabVisual, foram ricos e instigantes. Em especial, agradeço aos amigos - Gil, Cynthia, Gilfranco, Leandro, Lara e Tatiana - por compartilharem momentos importantes de descoberta, devaneios, dúvidas e incertezas. São pessoas que, nas horas mais complicadas, me inspiraram a continuar.

As explorações práticas, viagens e entrevistas, não teriam sido realizadas sem as pessoas que confiaram nesse trabalho. Agradeço ao Diego Spinola e seu pai, por aceitarem, de coração aberto, ser companheiros de aventuras importantes. Ao Estúdio Guto Requena e produtora D3, por me proporcionar a chance de aplicar na prática, os conceitos aqui estudados. A JanChristoph Zoels e equipe do escritório Experientia, bem como aos professores de Potsdam, que me receberam e deram a oportunidade de participar de seu cotidiano. A todos os entrevistados, que mostraram formas múltiplas de abordagens e práticas, ampliando meu horizonte.

Não posso deixar de agradecer o Nomads.usp, pela importância desse grupo na minha história enquanto pesquisadora. Especialmente ao Prof. Tramontano, que durante os sete anos que trabalhamos juntos, me preparou e inspirou para essa jornada.

Agradeço também a minha família, que nunca deixou de estar por perto, mesmo longe. Sobretudo aos meus pais, Marcos e Isa, por me ensinar sobre força, caráter, honestidade e dedicação. 


\section{English Abstract}

This work deals with the relation between architecture and technology, from the observation that, the potential of digital information processing is spreading, not only through the adoption and use of computing devices by people, but also, their addition on objects and places. Within this context, this study provides basis for the understanding and design of interactive architecture, a type of physical space that compels the implementation of interactions, enabled by digital information processors. To achieve this, the work is divided into three parts: context, fundamentals and design. At the first part, reading keys to understand instances with which the interactive architecture dialogues are provided. This type of spaces is understood, not as a consequence of technological development, but as part of a bigger, complex and connected context. Specifically, it addresses the interrelation between the ideological, technological and socio-spatial contexts. The second part, explores the topic of interactive architecture, as a result of technology introduction into the architectural product, and then, analyzes some aspects that give coherence to it as a specific form of intervention and expression. The third part, addresses the main issues that motivated this research, namely the design process of interactive architecture and the contributions that interaction design can provide this type of practice. Finally, nine parameters conceptual elements capable of being manipulated - are outlined to guide the design of interactive architecture. Among other uses, the function of these parameters is to expand the vocabulary and methods of architecture practice as a whole. Overall, the approach adopted is a means to explore and understand more about the technological world we live. The motivation to understand what is required to design the interactive architecture, that is, to include the technology in the final product, presupposes discussions that broaden the architectural field. It includes within it, the possibility and need for architects to act, beyond consumers of this technology, as active protagonists in their conformation.

Keywords: interactive architecture, interaction design, ubiquitous computing, experimental architecture, design, architecture design, digital technology, embedded electronics. 


\section{Resumo em Português}

Este trabalho trata da relação entre arquitetura e tecnologia digital, a partir da constatação de que a capacidade de processamento digital de informações está se espalhando não apenas pela adoção e uso de aparatos computacionais pelas pessoas, mas também por meio de sua inserção em objetos e lugares. Neste contexto, fornece bases para o entendimento e o design da arquitetura interativa, um tipo de espaço físico que pressupõe a implementação de interações viabilizadas por processadores de informação digital. Para tal, o trabalho é dividido em três partes: contexto, fundamentos e design. Na primeira, fornece chaves de leitura para o entendimento de instâncias com as quais a arquitetura interativa dialoga, colocando-a, não como uma consequência do desenvolvimento tecnológico e, sim, parte de um contexto maior, complexo e conectado. Especificamente, aborda a interrelação entre os contextos ideológico, tecnológico e sócioespacial. Na segunda parte, explora a arquitetura interativa enquanto conseqüência da incorporação da tecnologia no produto arquitetônico, para depois analisar aspectos que conferem coerência a ela enquanto uma forma particular de intervenção e de manifestação. A terceira parte aborda as principais questões motivadoras desta pesquisa, a saber: o design da arquitetura interativa e as contribuições que o design de interação pode fornecer a esse tipo de prática. Por fim, são esboçados parâmetros - elementos conceituais passíveis de serem manipulados - para guiar o design da arquitetura interativa. Entre outras utilidades, a função desses parâmetros é ampliar o vocabulário e os modos de trabalho da arquitetura como um todo. No geral, a aproximação realizada foi um meio de explorar e entender um pouco mais o mundo tecnológico que vivemos. Assim, a motivação de entender o que é necessário para projetar a arquitetura interativa, ou seja, para incluir a tecnologia em seu produto, pressupõe discussões que alargam o campo da arquitetura. Inclui nele, a possibilidade e necessidade de que arquitetos atuem, além de consumidores dessa tecnologia, como protagonistas ativos em sua conformação.

Palavras-Chave: arquitetura interativa; design de interação; computação ubíqua; arquitetura experimental; design; projeto de arquitetura; tecnologia digital; eletrônica embarcada. 
1.1 Contexto ideológico 16

1.1.1 A razão como instrumento do progresso 18

1.1.2 Tecnologia digital como símbolo do progresso ........ 22

1.1.3 Os limites da sociedade tecnológica ........ 26

1.1.4 Outras razões ........ 31

1.2 Contexto tecnológico ......... 35

1.2.1 Computadores e comunicação pós II Guerra Mundial

1.2.2 Três décadas de computador pessoal 46

1.2.3 Características básicas da tecnologia digital ........ 53

1.3 Contexto socioespacial .........58

1.3.1 Além do ciberespaço e das cidades inteligentes 60

1.3.2 Conexões contextualizadas 68

1.3.3 Paradoxos da tecnologia digital 74

\section{Fundamentos}

2.1 Arquitetura e tecnologia ....... 83
2.1.1 Processo 97
2.1.2 Produto 15

2.2 Estrutura ........ 112

2.2.1 Componentes 113

2.2.2 Materiais inteligentes 118

2.2.3 Iluminação dinâmica ....... 126

2.2.4 Cinética 136

2.3 Comportamento ........ 142

2.3.1 Lógica interna 144

2.3.2 Coerência externa 152

3.1.2 Arquitetura 163

3.1.2 Design de interação 173

3.2 Arquitetura e interatividade

3.2.2 Ambiente Interativo D3 184

3.2.2 Low2 No e fredericia $\mathrm{C}+$

3.3 Parâmetros conceituais para o design da arquitetura interativa 204

3.3.1 Participantes 207
3.3.2 Tempo 209
3.3.3 Interação ........ 211
3.3.4 Narrativas 213
3.3.5 Feedback 214
3.3.6 Tecnologia 216
3.3.7 Regras 217
3.3.8 Engajamento 218

3.3.9 Imprevisibilidade 220 
A preocupação em explorar a relação entre arquitetura e tecnologia digital parte da constatação de que a capacidade de processamento digital de informações está se espalhando não apenas pela adoção e uso de aparatos computacionais pelas pessoas, mas também por meio de sua introdução em objetos e lugares. Essa tecnologia, inicialmente restrita a laboratórios de empresas e universidades, tem crescentemente influenciado, direta e indiretamente, tanto processos de pensamento e produção quanto uma grande variedade de interações cotidianas.

Inicialmente, o computador pessoal alterou, significativamente, os modos de trabalho e a dinâmica dos escritórios de arquitetura. Aos poucos passou também a influenciar os modos de pensamento e de produção de espaços. Além disso, a miniaturização e o barateamento dos componentes têm viabilizado a inserção de sistemas digitais no espaço construído, dotando-o da capacidade de processar informações. Tal fato tem exigido dos designers e arquitetos a ampliação de sua prática e a elaboração de estratégias de projetos que englobem a especificidade desses sistemas, adaptando e revendo seus processos.

Esta tese busca compreender um dos produtos da relação entre a arquitetura e tecnologia digital. Nesse sentido, a arquitetura interativa é um tipo de espaço que pressupõe a implementação de interações viabilizadas por processadores de informação digital inseridos em sua estrutura. Todas as investigações realizadas, que serviram de base para a construção das discussões, colocadas ao longo da tese, foram feitas em função da adoção desse pressuposto em relação ao objeto estudado.

A partir desse objeto de investigação, o objetivo primeiro dessa pesquisa é explorar questões relacionadas aos processos de design que a produz. Dadas as diversas 
conotações da palavra design, é importante esclarecer que, nessa tese, refere-se ao contexto intelectual, o que a vincula à idéia de plano, desígnio e intenção (CARA, 2010), e é utilizado em alternância com a palavra projeto com o mesmo sentido. Dessa maneira, falar sobre processos de design significa abordar as diversas ações empreendidas para formatar e materializar conceitos intelectuais.

As inquietações, que atuaram como motivadoras deste estudo, compreendem um amplo panorama de questões. Por um lado, partiu-se da preocupação em definir o que é a arquitetura interativa, de onde e por que é relevante falar sobre isso, e em que medida suas características a diferenciam de uma arquitetura "não-interativa" ${ }^{1}$. A dúvida sobre a pertinência dessa questão e a busca de modos para descrever, categorizar e contextualizar esse tipo de espaço direcionou várias das explorações conduzidas.

Por outro lado, falar sobre arquitetura interativa significa, acima de tudo, referir-se a comportamentos implementados, por meio da programação. Nesta afirmação reside uma questão essencial que é a possibilidade de incluir no seu processo de design conceitos, estratégias, lógicas e raciocínios que se diferem daqueles presentes nos processos mais tradicionais da arquitetura. Até que ponto referencias a práticas de outros campos, que lidam com questões semelhantes, podem contribuir para o alargamento da prática da arquitetura, também foi uma questão sempre presente.

Para buscar respostas a essas indagações foi realizado um amplo trabalho de investigação, caracterizado pela convergência e alternância entre teoria e prática e pela aproximação com outros campos do conhecimento. Esse processo buscou, além de elucidar características específicas da arquitetura interativa, esboçar também aspectos da teia de relações na qual ela se inscreve, ampliando e contextualizando seu entendimento. $O$ resultado desse percurso é apresentado no corpo desta tese e, para complementá-la, primeiro são apresentadas particularidades do trabalho de pesquisa realizado.

\section{Contextualização}

As perguntas que permearam esta pesquisa de doutorado são frutos de constantes questionamentos sobre o papel do arquiteto do designer no início do Século XXI. Resultam da busca de compreender e discutir de que forma a prática desses

\footnotetext{
10 termo "não-interativo" é utilizado neste trabalho para designar os espaços que não possuem sistemas digitais incorporados em sua estrutura. Isso é feito apenas para diferenciar o objeto estudado de outros tipos de arquitetura e sem o intuito de assumir que em tais espaços não hajam formas quaisquer de interação.
} 
profissionais vem se alterando dentro do contexto colocado pela tecnologia digital, e quais novos caminhos de atuação esses profissionais podem encontrar nesta conjuntura. Essas questões sempre estiveram presentes e começaram a ser investigadas ainda durante a graduação ${ }^{2}$ junto ao Núcleo de Estudos de Habitares Interativos ${ }^{3}$ - Nomads.usp.

Especificamente, essa tese é continuidade direta da pesquisa desenvolvida no mestrado, junto ao grupo, que culminou na dissertação Objetos Interativos: Design e Tecnologias da Informação e Comunicação (CARNEIRO, 2008). Nessa pesquisa de mestrado, a principal questão era entender quais práticas e conhecimentos o arquiteto precisaria incorporar para ser capaz de criar objetos interativos, ou seja, objetos com a capacidade de processamento digital de informação. Subjacente a isso, estava o desejo de utilizar a tecnologia digital como um meio de expressão, como uma camada adicional do objeto, que pudesse ser manipulada na sua essência.

Além do contato com teorias e obras, o interesse sobre o assunto, culminou em um intercâmbio com o Interface Culture Department, na cidade de Linz, na Áustria, um dos principais polos da arte mídia mundial. Na prática, durante sete meses, foi possível explorar os conceitos estudados ao longo dos anos e, acima de tudo, aprender e praticar programação e desenvolvimento de circuitos eletrônicos. Durante essa experiência, foi desenvolvido o projeto Affective Twins, um protótipo de mobiliário interativo, exposto no Ars Electronica Festival 2007 (Figuras 1-3).

De volta ao Brasil, junto ao Nomads.usp, foi concebida e construída a fachada PIX (Figuras 4-5). O projeto consistiu no desenvolvimento e montagem de um display de baixa resolução, na fachada do edifício 001, sede do grupo Nomads.usp. Compreendeu a introdução de uma matriz com 1200 LED's controlados, individualmente, através dos quais imagens e animações luminosas podem ser visualizadas. A idéia foi trabalhar a integração do espaço físico e do informacional, de forma que, além de funcionar como um painel conectado à internet, o projeto integrasse o display à estrutura, de forma a se tornar indissociável do edifício.

\footnotetext{
${ }^{2}$ Entre 2002 e 2008, foram realizadas três pesquisas individuais financiadas, além da participação em outros projetos de pesquisa. Das três bolsas, duas foram de iniciação científica (Fipai e FAPESP) e uma de mestrado (FAPESP).

${ }^{3}$ O Nomads.usp é um grupo de pesquisa do Instituto de Arquitetura e Urbanismo de São Carlos, Universidade de São Paulo. Os trabalhos desenvolvidos no Núcleo buscam explorar as relações entre tecnologias, comportamento e espaço construído de diversos modos: seja na escala urbana, com a inclusão da comunidade em processos de comunicação mediada, seja na escala do edifício, com pesquisas sobre novos paradigmas de projeto, seja na escala do mobiliário, com o design de peças de mobiliário e objetos com mídias integradas, seja ainda na escala do corpo, com a exploração de relações entre corpo e espaço mediadas por dispositivos informatizados. Web-site do grupo: <http://www.nomads.usp.br>. Acesso em: 1 fev. 2014.
} 


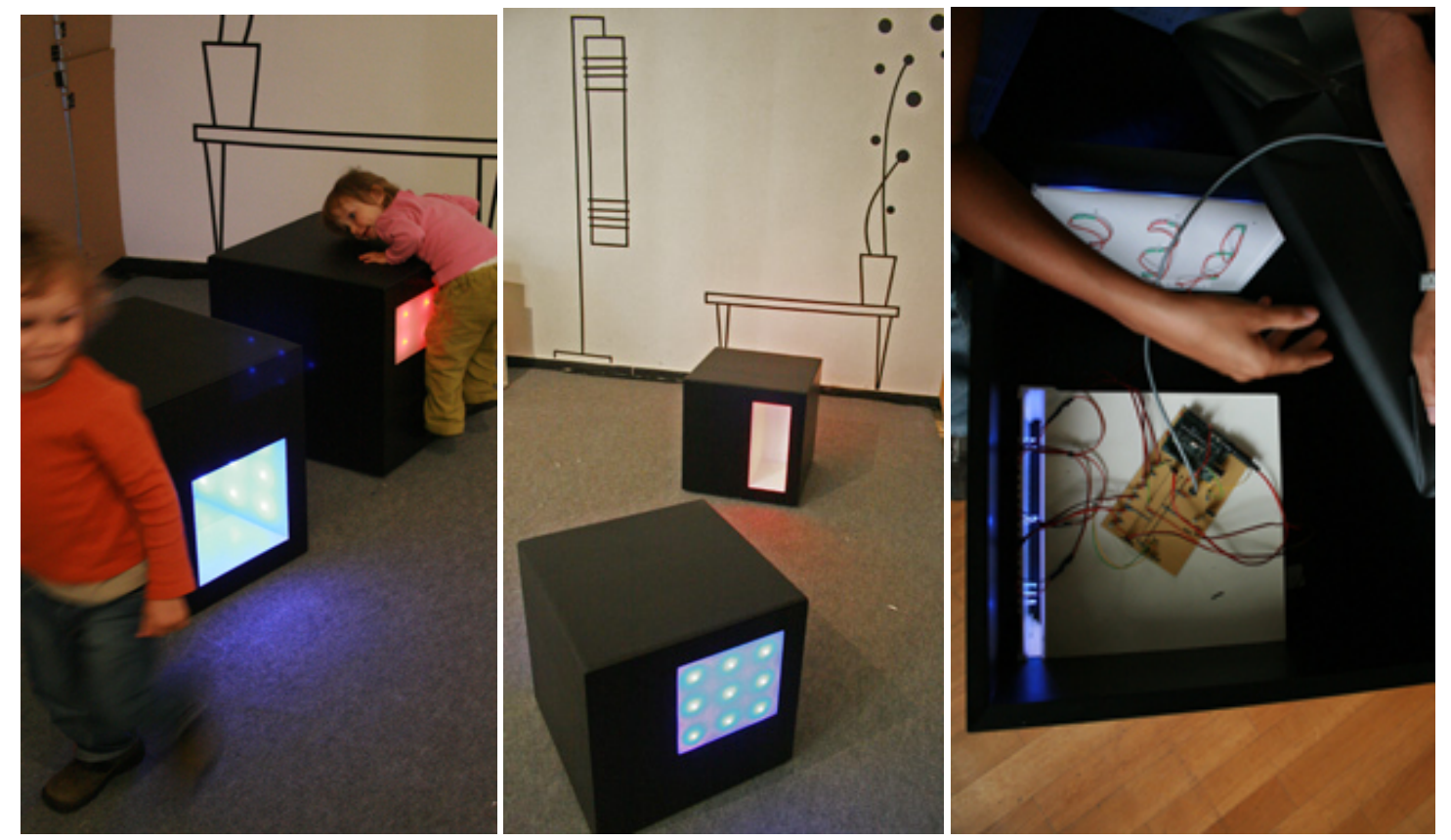

Figuras 1 a 3 - Affective Twins, Gabriela Carneiro, 2008 (Fonte: Gabriela Carneiro, 2007).
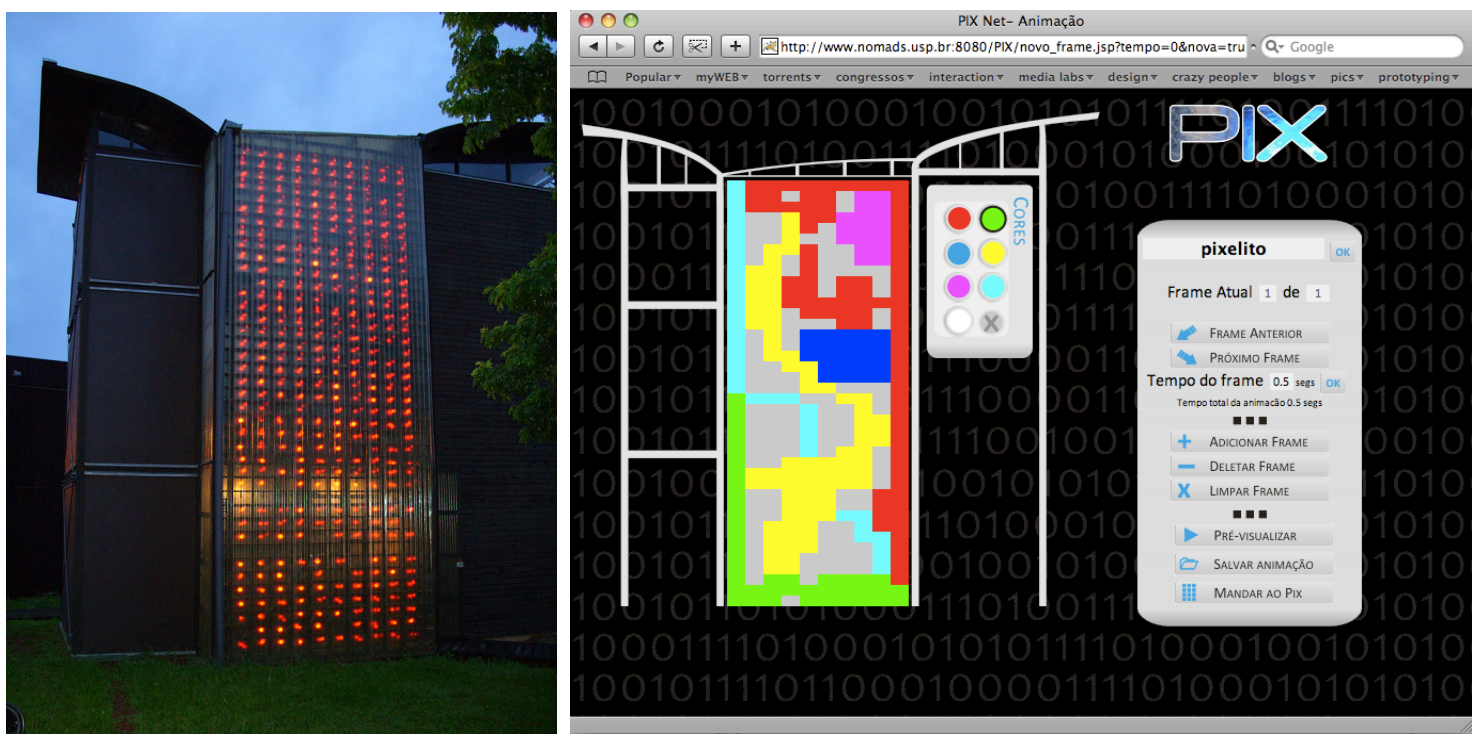

Figura 4 - Projeto PIX: Fachada do edifício 001 com o painel de LED's ligado (Fonte: Nomads.usp, 2008).

Figura 5 - Projeto PIX: Interface gráfica para a preparação de animações (Fonte: Nomads.usp, 2008).

Seu projeto consistiu na integração de três frentes de trabalho: uma responsável pela estrutura, outra pelo circuito e uma terceira pela sua interface web. Neste processo, as fases clássicas de concepção, desenvolvimento e produção foram integradas em um procedimento único, no qual ocorre a interação interdependente entre intencionalidade artística, expectativas comunicacionais e feedback dos inter-atores (nesse caso, os envolvidos no processo).

A escala do objeto, abordada no mestrado, possibilitou a investigação de inúmeras questões práticas e teóricas. A possibilidade de prototipar sistemas e testar objetos, sendo apropriados pelas pessoas, abriu caminho para as discussões do doutorado. A 
prática permitiu a imersão no mundo digital e, com isso, o próximo passo consistiu em voltar o foco para a arquitetura.

Faz-se importante pontuar estes anos de pesquisa, pois eles foram importantes na introdução a esse emergente universo da cultura digital, relacionado à arquitetura e ao design, e, mais especificamente, às questões do design de interação. A alternância entre exploração teórica, pesquisa de aplicações e atividades práticas foram fundamentais e determinaram o levantamento das questões que permeiam o presente trabalho de doutorado.

Esse percurso prévio, caracterizado pelo contato com teóricos, praticantes, e com os processos de design e de desenvolvimento deste tipo de obra, justifica o interesse pelo tema e valida a importância de uma pesquisa acadêmica nesta área. A presente proposta e os questionamentos que a permeiam são frutos desta aproximação e buscam fomentar a constituição de um saber brasileiro nessa subárea emergente. Busca-se, assim, produzir conhecimento voltado para realidades nacionais, ao mesmo tempo em que se vislumbra uma aproximação com diferentes campos disciplinares. Uma vez que o crescente acesso à tecnologia e à informação faz com que os espaços e edifícios interativos tornem-se mais comuns a cada dia, julga-se importante um estudo que auxilie na fundamentação crítica e na indicação de caminhos para este tipo de prática.

\section{Objeto}

O objeto investigado, ao longo desta tese, é a arquitetura interativa, uma das possíveis manifestações da arquitetura. Trata-se de espaços e edifícios cuja interatividade é viabilizada pela implementação de sistemas de processamento digital de informação. Nesse sentido, ela pressupõe a introdução de sistemas digitais no produto arquitetônico. Sua especificidade é contrastada com espaços "não-interativos", aqui entendidos como todos aqueles que não possuem tecnologia digital em sua conformação física. Nesse sentido, todas as investigações realizadas, que serviram de base para a construção das discussões colocadas, ao longo da tese, foram feitas em função de explorar as características desse objeto e de contribuir para os processos de design que precedem sua implementação.

\section{Hipótese}

Desde o início, a investigação da arquitetura interativa, a partir de seus modos de pensamento e produção, foi feita com o intuito de mostrar que seu processo de design 
depende, necessariamente, de perspectivas e métodos advindos do design de interação. Portanto, a hipótese inicial consistiu em investigar e constatar que o design de interação fornece para a arquitetura interativa os elementos que ela necessita para ser pensada e realizada.

Partia-se, assim, do pressuposto que os parâmetros de criação da arquitetura "nãointerativa" não seriam suficientes e que o design de interação forneceria as referências para complementar o quadro de ferramentas e estratégias necessárias para a criação de espaços interativos. Neste caso, a arquitetura interativa era compreendida (e reduzida) como este "espaço-entre" - local de diálogo entre duas áreas do conhecimento: a arquitetura e o design de interação.

Ao final, elucida-se a relevância da hipótese inicial enquanto ferramenta para investigação do objeto de estudo. A pesquisa foi desenvolvida, a partir das particularidades da arquitetura interativa enquanto domínio de conhecimento e ação, e dispôs-se a investigar as possibilidades advindas do design de interação, uma disciplina ainda em construção.

Assim, paralela à busca de um entendimento do que é a arquitetura interativa, seguiuse um esforço em apreender as particularidades do design de interação e sua aplicabilidade no objeto em questão. O desenvolvimento de métodos e projetos (i/o Cards, Ambiente D3 e FredericiaC+), a realização de visitas e entrevistas e um intenso aprofundamento bibliográfico foram as bases criadas para a verificação da hipótese.

O que foi constatado, ao final de quase quatro anos, é que a hipótese é válida, porém, não é suficiente. A relação pragmática entre a arquitetura interativa e o design de interação é válida, ou seja, são vários os recursos que podem ser apropriados entre as disciplinas de forma a enriquecê-las. Assim, verifica-se ser totalmente plausível a determinação de um plano de ação entre estes dois contextos e, neste sentido, tornase imprescindível que a arquitetura interativa incorpore, em seu discurso, questões advindas do design de interação. Porém, o que a investigação também mostrou é que o design de interação não é capaz de fornecer todas as estratégias necessárias para o pensamento e criação da arquitetura interativa.

Diversos são os fatores que estabelecem estes limites, sendo que um deles está ligado à própria natureza do design de interação, um campo ainda em construção, que busca incorporar princípios do design (enquanto campo do conhecimento) à criação de interfaces digitais. Neste sentido, o próprio pensamento que permeia esse campo 
específico do design é amplamente questionado, como fazem, por exemplo, Dourish (2004) e McCullough (2004), ao apontarem o caráter pragmático e determinista que envolve o discurso fundamental da criação de interfaces no mundo contemporâneo. Em suas análises, os autores explicitam os limites do pensamento que rege o design de interação, em especial no que se refere à incorporação de questões relacionadas à interação por meio do corpo e seus diversos atributos de percepção e interpretação do mundo, que extrapolam a cognição. O design de interação, neste sentido, é uma ferramenta preciosa de pensamento, porém, subordinada à ideologia que a originou, e seus limites precisam ser sempre analisados criticamente.

Um outro fator importante que limita a relação entre a arquitetura interativa e o design de interação compreende os condicionamentos específicos da arquitetura, ou seja, da criação dos espaços físicos. Neste aspecto, outras referências também são essenciais para seu pensamento. A escala de intervenção da arquitetura interativa requer outros planos de entendimento e pensamento, que vão além daqueles abordados pelo design de interação.

Questões urbanas e sóciotecnológicas, tal como colocadas por Zizek (2002), Sassen (2002) e Santos (2002), precisam ser consideradas para abrir a possibilidade de outros planos de ação e territórios de exploração. A investigação destes limites contribuiu, em especial, para o entendimento da complexidade que subjaz a criação e a manifestação do objeto de estudo, que esta pesquisa mostrou ir além da incorporação pragmática dos métodos e pensamentos, advindos do design de interação.

\section{Objetivos}

A redação da tese foi feita de forma a aprofundar todo o questionamento já exposto, acerca do objeto estudado e do movimento feito, desde a elaboração da hipótese inicial até as conclusões elaboradas, a partir de sua investigação. Neste sentido, o objetivo principal a ser alcançado, consiste na proposição de parâmetros para o design da arquitetura interativa, que incorpore criticamente estratégias do design de interação e contribua para o entendimento do significado deste tipo de espaço no contexto contemporâneo.

Como parte da busca de elucidar a complexidade das questões que envolvem o objeto investigado e fornecer parâmetros para seu design, a tese abrange os seguintes objetivos específicos: 
- Explicitar a que exatamente o termo arquitetura interativa se refere no contexto deste trabalho (rumo a uma definição do termo e de um campo de investigação/intervenção);

- Analisar o contexto do qual a arquitetura interativa faz parte (que a condiciona e é condicionado por ela), fornecendo chaves de leitura para sua contextualização crítica;

- Esboçar limites do pensamento arquitetônico hegemônico, de forma a identificar oportunidades de incorporação de outros parâmetros de criação;

- Fazer uma breve análise do contexto e dos pressupostos que deram origem ao design de interação, com ênfase tanto nos limites deste pensamento quanto nas questões que podem contribuir significativamente para a arquitetura interativa.

Os objetivos específicos desta tese foram sendo elaborados e redigidos de forma a fornecer a base necessária para se entender os pressupostos que balizam os parâmetros conceituais para o design da arquitetura interativa. De forma que a elaboração destes compreende o objetivo principal a ser alcançado por esta pesquisa de doutorado, e, consequentemente sua contribuição original. Por mais que análises e investigações, acerca da relação entre a arquitetura e a tecnologia digital, sejam temas cada dia mais em voga, esta tese pretende ocupar um espaço específico. Assim, seu diferencial reside em um movimento duplo: de entendimento crítico destes contextos paralelamente à proposição de estratégias de design.

\section{Processo e Produtos}

Nigel Cross (2007) aponta que conceitos e teorias sobre o design podem ser obtidos, a partir de três aproximações. Segundo o autor, por meio das pessoas que praticam o design é possível obter informações sobre as diferentes perspectivas sobre um mesmo assunto. Além disso, a proximidade com a prática possibilita o entendimento de processos de concepção, desenvolvimento e produção. Por fim, a análise de produtos do design gera insumos para o reconhecimento de padrões relacionados à forma e configuração, resultante de determinadas práticas. Neste sentido, acredita-se que a multiplicidade de ações empreendidas, nesta pesquisa, é de grande importância para seu processo, já que fundamenta o fornecimento de um panorama geral das questões envolvidas no design da arquitetura interativa.

Em síntese, quatro movimentos distintos e complementares podem ser descritos, para melhor caracterizar o processo de pesquisa empreendido. São eles: revisão 
bibliográfica, entrevistas com profissionais, experimentações práticas e redação de artigos. Algumas dessas atividades foram previstas no plano inicial e outras foram introduzidas devido a oportunidades e necessidades que surgiram ao longo de seu desenvolvimento.

A revisão bibliográfica foi realizada ao longo de todo o trabalho e pode ser caracterizada por três momentos. O primeiro compreende os textos lidos no início da pesquisa, os quais tinham como tema a arquitetura interativa e o design de interação. O objetivo foi entender o estado da arte destes dois campos para criar a base conceitual da investigação. Em um segundo momento, anterior à qualificação, textos sobre processos de design foram introduzidos no escopo de leituras. Isso se deu em especial, para encontrar pontes para o diálogo entre as duas áreas. Após a qualificação, em detrimento da sugestão da banca e também do parecerista da FAPESP, a pesquisa bibliográfica foi ampliada de forma significativa para entender criticamente o contexto no qual se insere esse tipo de arquitetura. Esses movimentos estão refletidos diretamente no conteúdo e na organização dos capítulos desta tese.

Além da revisão bibliográfica, foram efetuadas nove entrevistas com profissionais que trabalham com questões próximas àquelas tratadas pela pesquisa, escolhidos de acordo com seu tipo de prática e com as oportunidades que apareceram, ao longo da pesquisa. As entrevistas foram essenciais para a pesquisa, pois, ao mesmo tempo em que desmistificaram alguns aspectos chave das práticas que trazem a tecnologia digital para a arquitetura, também abriram novos caminhos de investigação. Foram entrevistas semi-estruturadas com a duração limite de uma hora e compostas de três blocos de perguntas:

- Introdução: Na parte introdutória, o foco foi investigar o histórico e motivações iniciais dos entrevistados. O objetivo foi explorar de onde partiram e o que os levaram a ter contato e introduzir a tecnologia digital em seus trabalhos;

- Processos: Na segunda parte, foram explorados projetos desenvolvidos pelos entrevistados cujo conteúdo contribui para o tópico explorado por esta pesquisa. $\mathrm{O}$ foco das indagações foi o processo criativo destes projetos;

- Conceitos e futuro: Na terceira parte da entrevista, foram explorados tanto os conceitos e idéias resultantes da prática estabelecida pelos entrevistados, quanto a visão que possuem para o futuro da sua prática.

Todas as entrevistas foram gravadas e transcritas e fazem parte do acervo pessoal da pesquisadora. Algumas são citadas ao longo da tese. Porém, é necessário deixar claro 
que todas foram importantes para a elaboração do discurso como um tudo. Abaixo segue a lista de entrevistados:

- Jan-Christoph Zoels: Designer de interação, há 20 anos. Recentemente, tem participado de competições junto a escritórios de arquitetura para o desenvolvimento de estratégias de desenvolvimento urbano. Explora como as ferramentas etnográficas do design de interação pode auxiliar em projetos arquitetônicos;

- Carlos Alarcoon Aalen: Gerente de projeto do escritório de arquitetura Sauerbruch Hutton, responsável pelo projeto Low2No, em parceria com Experientia e Arup. O objetivo da entrevista foi entender, de acordo com o ponto de vista do escritório de arquitetura, as potencialidades e limitações da aplicação de metodologias do design de interação;

- Joachim Sauter: Fundador e diretor do escritório de mídia design ART+COM, que desenvolve projetos de espaços interativos, há 25 anos;

- Tim Edler: Fundador do realites:united. Junto com o irmão Jan Edler vem desenvolvendo inúmeros projetos de mídia fachadas e arquitetura interativa. Contou como aconteceu o primeiro projeto do estúdio, A fachada BIX para o museu de artes Kunsthausgraz, e o que aconteceu depois disso;

- Stephen Gage: Arquiteto e professor da Barttlet. Relatou suas experiências com a tecnologia digital e a influência dos pensadores cibernéticos dos anos 60 e 70, incluindo seu convívio com Gordon Pask. Acompanhou toda a evolução dos computadores;

- Ruairi Glynn: Mídia designer, arquiteto, curador, escritor, artista. Trabalha a relação entre robótica e arquitetura.

- Dominic Harris: Arquiteto, fundador e diretor criativo do estúdio Cinimod. Relata sobre os desafios de se criar e manter uma prática comercialmente viável que introduz tecnologia nos espaços.

- Mathias Gmachl e Rachel Wingfield: Com formações diversas, fundadores do Loop-ph, possuem uma prática cujo produto é o próprio processo de pesquisa. Abordam a relação da arquitetura com a tecnologia e a importância de envolver a comunidade na concepção de espaços mais vivos e cheios de valores.

- Richard Robert: Arquiteto, professor e coordenador de projetos do estúdio Jason Bruges. Com experiência prévia de trabalho em escritórios tradicionais de arquitetura, fala sobre similaridades e diferenças nos processos de design dos quais participou. 
De modo geral, a percepção mais importante foi a multiplicidade das práticas. Os entrevistados foram escolhidos, a partir de um pressuposto inicial, no qual pertenceriam a uma mesma categoria: a de designers e arquitetos que pesquisam, concebem e desenvolvem idéias e projetos nos quais a tecnologia é parte fundamental. Uma vez que as entrevistas foram sendo realizadas percebeu-se a multiplicidade de suas perspectivas, motivações e processos. Um fator fundamental pois esta pesquisa busca justamente organizar e delinear possibilidades para o desenvolvimento deste tipo de projeto.

Por outro lado, pontos semelhantes foram identificados. Entre eles, a questão da interação e como seu uso deve ser calcado em necessidades cuidadosamente levantadas. Há uma unanimidade de que a presença da interação não garante, de forma alguma, um projeto mais interessante ou melhor. Em relação ao papel da tecnologia na prática, todos apontam para seu entendimento enquanto mais uma ferramenta disponível, sendo que muitos afirmam também que a análise de sua influência não pode ser restrita à adição de componentes. É necessário atentar-se para o fato de que projetos refletem as características da tecnologia digital, mesmo sem ela estar presente.

A questão da avaliação do resultado final, ou mesmo a análise da experiência que este tipo de espaço media, é sempre muito relativa. Isso deve ser analisado caso a caso assim como acontece com qualquer outro tipo de espaço. Varia, de acordo com as intenções iniciais de projetos e da motivação por produzir determinado espaço. Segundo Gage (2011), podemos apenas falar em cenários, o que também é um ponto comum, notado nas entrevistas.

No que diz respeito às experimentações, foram realizados quatro projetos. O primeiro são as i/o Cards (CARNEIRO, 2012), um conjunto de cartas concebidas para estimular a conversação e troca de idéias, durante a concepção de objetos interativos. Elas são divididas em dois grupos, um trabalha questões estruturais do sistema interativo e o outro aborda algumas preocupações conceituais necessárias para a criação de experiências interativas. Foram utilizadas em diversas e diferentes dinâmicas colaborativas de projeto, tanto para conceber objetos quanto arquiteturas interativas.

O segundo projeto, Ambiente Interativo D3 (CARNEIRO; SPINOLA et al, 2011), foi realizado em conjunto com um escritório de arquitetura. Tratou-se do projeto de um espaço comercial de, aproximadamente, $70 \mathrm{~m}^{2}$ para uma produtora digital, no qual foi possível inserir questões trabalhadas pela pesquisa desde os primeiros estudos e 
esboços do espaço, até a construção, implementação e posterior avaliação dos resultados. Essa experiência não só permitiu a experimentação prática do processo de design de uma arquitetura interativa, mas também abriu a oportunidade para diversos outros questionamentos e ações.

Ao longo da pesquisa, surgiu também a oportunidade de contribuir para a concepção do projeto Fredericia ${ }^{4}{ }^{4}$ como parte da equipe do escritório de design de interação, em conjunto com escritórios de engenharia e arquitetura. De modo geral, a participação neste projeto permitiu um entendimento maior das estratégias do design de interação. Como parte da equipe de desenvolvimento da proposta, a pesquisadora pode entender na prática como pensar, preparar e aplicar algumas estratégias específicas, bem como metodologias do design de interação. Dentre elas, a criação de personas, dia na vida (day in a life), cenários, metodologias participativas de design, e playful cards.

Por último, foi também desenvolvido o projeto SeedArchSystem, como resultado da participação em uma das edições da AA Visiting School, iniciativas da Architectural Association que compreendem cursos intensivos de curta duração com temáticas diversas. O workshop incluía a experimentação com máquinas de fabricação digital (CNC, impressora a laser, corte de adesivos), e softwares diversos (Rhino e seu plugin Grasshopper, Arduino, Processing e Ecotec), no contexto de produção tradicional do carnaval.

A importância do trabalho desenvolvido, ao longo do workshop, reside na experimentação com tecnologias a cada dia mais presentes na produção arquitetônica, tal como as de programação (Rhino e Grasshopper) e fabricação (CNC e corte a Laser). Sua utilização, junto com a experimentação de um processo de design não linear, forneceram entendimentos práticos de conceitos até então não experimentados pela pesquisadora. Este fato foi essencial para promover novos níveis de entendimento dos textos que fundamentam esta pesquisa.

Por fim, durante a redação dos artigos foi possível a sistematização e análise das atividades práticas. Essas análises também se configuraram como importantes momentos de diálogo com o orientador e com outros pesquisadores. Alguns desses

\footnotetext{
${ }^{4}$ Informações sobre o concurso e as propostas dos quatro times que disputaram a competição paralela para a area estão disponíveis em:

<http://www.fredericiac.dk/Planer+og+byggeri/Parallelkonkurrencen/Holdenes+forslag.aspx>. Acesso em: 5 fev. 2014.
} 
artigos, resultaram das experimentações e aprofundam os processos dos projetos, em especial, do desenvolvimento do Ambiente D3 e das i/o Cards. Outros artigos resultaram também do diálogo com pesquisas relacionadas. Destaca-se, aqui, a coautoria, em artigos, com o pesquisador Barros (CARNEIRO; BARROS; COSTA, 2010, 2011 e 2012; BARROS; CARNEIRO, 2013), cuja pesquisa era especificamente sobre design de interação, sendo que as discussões muito contribuíram para um aprofundamento sobre o trabalho específico desse campo.

\section{Estrutura da tese}

Todo esse caminho gerou insumos importantes para um entendimento teórico dessa prática e para a prática de questões teóricas. Nesse espaço, que esta tese se insere. 0 resultado é apresentado em três capítulos, além da Introdução e das Considerações Finais. A elaboração dos capítulos apresenta as principais questões que foram necessárias para a exploração do tema. Seus temas, ao mesmo tempo, paralelos e complementares, foram assim organizados:

O Capítulo 1 - Contextos Conectados - fornece chaves de leitura para o entendimento de instâncias com as quais a arquitetura interativa dialoga, colocando-a, não como uma consequência do desenvolvimento tecnológico e, sim, parte de um contexto maior, complexo e conectado. No contexto ideológico são inicialmente analisadas as questões que permeiam o atual discurso hegemônico, calcado na razão instrumental e no ideal de progresso, para depois delinear o que seriam outros discursos possíveis. 0 contexto tecnológico compreende uma breve análise das ideias que influenciaram a formatação da computação, em especial, aquelas elaboradas durante e após a II Guerra Mundial. O contexto socioespacial aborda a contextualização dos discursos tecnológicos e ideológicos, mostrando que é nele que os antagonismos do paradigma técnico se manifestam intensamente.

O Capítulo 2 - Fundamentos - esboça as especificidades da arquitetura interativa com o objetivo de expandir o entendimento geral dos espaços construídos pelo homem e das ações que neles acontecem, incluindo, assim, questões trazidas pela tecnologia digital. Para isso, aspectos gerais da relação entre arquitetura e tecnologia são esboçados, de acordo com dois aspectos, a saber: do processo e do produto. Em seguida, a partir do entendimento da arquitetura interativa, enquanto incorporação da tecnologia no produto, são analisados aspectos que conferem coerência a ela enquanto uma forma particular de intervenção e de manifestação. Para isso, são 
esboçados dois aspectos que lhe conferem especificidade, os recursos materiais utilizados para implementá-la e seu comportamento.

O Capítulo 3 - Design - aborda as principais questões motivadoras dessa pesquisa, a saber: o design da arquitetura interativa e as contribuições que o design de interação pode fornecer a esse tipo de prática. Para isso, primeiramente, são contextualizadas algumas especificidades do processo de design no campo da arquitetura e do design de interação. Em seguida, são analisados processos de design de três projetos (Ambiente Interativo D3, Low2No e Fredericia C+) que indicam, na prática, possibilidades de diálogo entre esses campos. Por fim, são esboçados alguns parâmetros, ou seja, elementos conceituais passíveis de serem manipulados, sistematizados por esta pesquisa para guiar o design da arquitetura interativa.

Por fim, a tese é encerrada com o capítulo Considerações Finais, no qual é delineado um panorama conjunto dos assuntos abordados nesse estudo. Além de registrar os principais pontos do que foi efetivamente aprendido com a pesquisa, são esboçados limites do discurso e possibilidades de aprofundamentos de alguns temas abordados. Por meio desse caminho, espera-se fomentar discussões e aproximações críticas sobre a arquitetura interativa e seus processos de design. 
Dada a sua complexidade, o contexto do qual a arquitetura interativa faz parte corresponde a um tipo de fenômeno cuja definição de um recorte e posterior análise será sempre um desafio. Não há, aqui, a pretensão de incluir todas as questões contemporâneas que influenciam e são influenciadas pela prática da arquitetura interativa, ou mesmo de esgotar aquelas abordadas. Outras relações podem, e devem, ser estimuladas e aprofundadas. Entretanto, elaborar qualquer discurso que busque destacar aspectos específicos do desenvolvimento e do impacto da tecnologia digital, na sociedade como um todo, é sempre um desafio. Recortes e pontos de vista são sempre necessários e, como resultado, corre-se o risco de excluir do discurso questões importantes. Neste sentido, o objetivo deste capítulo é fornecer chaves de leitura para o entendimento de instâncias com as quais a arquitetura interativa dialoga, colocandoa não como uma consequência do desenvolvimento tecnológico e sim parte de um contexto maior, complexo e conectado.

No contexto ideológico, inicialmente, são analisadas as questões que permeiam o atual discurso hegemônico, calcado na razão instrumental e no ideal de progresso, para então delinear o que seriam outros discursos possíveis. Fez-se isso, com o objetivo de elucidar formas pelas quais valores e entendimentos de mundo encontram-se, muitas vezes, ocultos nos discursos e ações. Além de ser imprescindível para a compreensão e aprofundamento do conteúdo desta tese, trata-se de um movimento necessário para a elaboração de qualquer perspectiva que pretenda incorporar aspectos críticos em seu discurso.

O contexto tecnológico compreende uma breve análise das ideias que influenciaram a formatação da computação, em especial, aquelas elaboradas durante e após a II Guerra Mundial. Com o advento do computador pessoal, essas ideias foram materializadas e, acima de tudo, os métodos e valores computacionais passaram a ser, progressivamente, incorporados pelo senso comum. Apesar de a tecnologia digital ser 
comumente associada a mudanças rápidas e revolucionárias, sua essência continua a mesma de décadas atrás. O entendimento de seus fundamentos, além de esclarecer essa percepção, é um dos pontos fundamentais para compreender sua relação com a arquitetura interativa.

O contexto socioespacial aborda a contextualização dos discursos tecnológicos e ideológicos. É nele que os antagonismos do paradigma técnico se manifestam intensamente. Os discursos associados ao ciberespaço e à cidade inteligente ilustram como a tecnologia se entrelaça com as expectativas humanas. Os diferentes aspectos que envolvem a contextualização da tecnologia digital aprofundam esse entendimento. Por fim, o entendimento de sua natureza paradoxal elucida que a arquitetura interativa, assim como as demais manifestações tecnológicas, deve ser compreendida e elaborada, incluindo questões, aparentemente contraditórias, à realidade.

Ressaltando as especificidades destes diferentes contextos, espera-se, por um lado, embasar criticamente as discussões colocadas por esta tese. Por outro, a intenção é apresentar a arquitetura interativa como parte de um contexto muito maior no qual tecnologia e subjetividade exercem papeis por vezes complementares e, por vezes, contraditórios. Ideologia, tecnologia e espacialidade são temas que oferecem leituras alternativas para a questão da arquitetura no contexto contemporâneo. Em especial, é importante perceber que a arquitetura interativa deve ser pensada e realizada, não apenas porque o desenvolvimento técnico abre essa possibilidade, mas sim, por se configurar como uma maneira importante e específica de contemplar, questionar e atuar, frente à complexidade das questões contemporâneas como um todo.

\subsection{Contexto ideológico}

Qualificar a ciência como capaz de encontrar e provar a verdade; afirmar que a tecnologia, necessariamente, melhora a vida do homem; trabalhar com o objetivo de acumular dinheiro e consumir os últimos lançamentos de algum produto. Essas afirmações descrevem pensamentos e ações que derivam de conceitos e valores, ou seja, de uma determinada ideologia ${ }^{5}$ que, segundo Chauí (2012), relaciona-se diretamente ao conjunto de ideias e explicações que uma sociedade oferece sobre si mesma.

\footnotetext{
5 Segundo Marcondes Filho (1985, p.15), ideologia é um termo cujo significado foi bastante ampliado desde sua utilização nas teorias de Karl Marx, nas quais era utilizado para designar o "conjunto de idéias que cada classe possuía". Para esboçar a complexidade que o termo adquiriu - e nesta tese é adotado com este sentido mais amplo - Marcondes Filho menciona seis características: 1) ela sempre pertence a um grupo de pessoas (não é individual); 2) é representada por símbolos, rituais e estereótipos; 3) está sempre relacionada a um conjunto de valores; 4) mais do que uma questão política, trata-se de uma visão de mundo; 5) mais do que um conjunto de idéias, ela possui uma capacidade de mobilizar as pessoas para a ação;6) é realmente percebida não pelo discurso e sim pela natureza das ações.
} 
Neste sentido, falar sobre contexto ideológico, significa analisar a origem e os pressupostos das afirmações coletivamente nele reproduzidos, implícita ou explicitamente, como observa Marcondes Filho (1985, p.20):

Quando pretendemos alguma coisa, quando defendemos uma idéia, um interesse, uma aspiração, uma vontade, um desejo, normalmente não sabemos, não temos consciência que isso ocorre dentro de um esquema maior, de um plano, de um projeto maior, do qual somos apenas representantes - repetimos conceitos e vontades, que já existiam anteriormente.

Refletir sobre as ideias e pressupostos deste esquema maior favorece o entendimento que se tem da realidade, como ele é construído e qual é o papel de cada indivíduo nesta coletividade. De certa maneira, a ideologia é inevitável, ou seja, não é possível entender o mundo exatamente como ele é experienciado, de forma que qualquer compreensão será sempre distorcida e influenciada. Ainda assim, é aprofundando estas questões que se torna praticável o entendimento da natureza dos conceitos e das ações sobre o mundo.

Uma vez que ver os fatos de forma ideológica é característica nossa, o que se pode almejar é conhecer exatamente o que é essa ideologia, o que são as demais ideologias e saber discernir, dentre elas, qual é a que mais corresponde aos nossos valores, qual é a expressão mais aproximada da verdade (MARCONDES FILHO, 1985, p.20).

Isso posto, uma vez que esta tese apresenta uma reflexão sobre tecnologia digital e arquitetura, torna-se relevante esboçar quais são os valores que assinalam esta relação. Especificamente, dado o grande impacto da inserção da tecnologia nos mais diversos âmbitos da vida cotidiana, é importante delinear traços da ideologia que permeia seu desenvolvimento, sua disseminação e sua função na sociedade. Parte-se do pressuposto de que, só assim, é possível um aprofundamento sobre o tema que ultrapasse o discurso pragmático e hegemônico, e que permita a inclusão de outros modos de pensamento e ação.

A ideologia que permeia o desenvolvimento tecnológico é marcada, dentre outras particularidades, por um conceito de racionalidade único, voltado para o progresso. Segundo Vassão (2008, p.3), a naturalização ${ }^{6}$ da ideologia tecnológica é devida, em grande parte, à sua ampla disseminação, dado que, "[...] a emergência da informática, e sua banalização como item de consumo de massa, assim como infra-estrutura urbana, é uma história rica em filosofia, inovações culturais e a construção

60 termo naturalização é aqui utilizado para designar a adoção de valores e pressupostos da tecnologia digital como naturais, ou seja, como algo que sempre existiu e que, portanto, torna-se inevitável. Como consequência desta abordagem, só cabe às pessoas lidarem com eles e tirarem o melhor proveito do que é assim posto. 
perfeitamente imanente de uma abordagem informacional de grande alcance sóciocultural".

Neste sentido, os aspectos aqui analisados fornecem suporte para a apreensão deste plano maior, que inclui pressupostos, visões de mundo e estratégias de ação específicas, cujo entendimento é fundamental para a construção de uma reflexão crítica. Assim, o contexto ideológico é aqui esboçado com o intuito não só de elucidar valores e entendimentos de mundo ocultos nas práticas da sociedade ocidental, mas também questioná-los e mostrar outros pensamentos possíveis que serão retomados ao longo da tese.

\subsubsection{A razão como instrumento do progresso}

Segundo Chauí (2012, p.79), "[...] na origem, [a] razão é a capacidade intelectual para pensar e exprimir-se correta e claramente, para pensar e dizer as coisas como são". Trata-se de uma maneira de organizar e compreender a realidade, com base na capacidade do pensamento humano e na confiança de que as coisas são ordenáveis, ou seja, elas também possuem sua própria razão. Portanto, por meio da razão é possível conhecer e dar significado ao mundo.

É a partir dessa capacidade humana que surge uma forma específica de pensamento, denominado científico, o qual se contrapõe ao senso comum e às opiniões. Sua especificidade encontra-se na busca metódica e sistemática que utiliza para produzir conhecimento. Este pensamento é a base da ciência, definida por Abbagnano (2012, p.157), como o "[...] conhecimento que inclua, em qualquer forma ou medida, uma garantia da sua própria validade" ${ }^{\prime 7}$. Sua investigação característica constitui "[...] um conjunto de atividades intelectuais, experimentais e técnicas, realizada com base em métodos que permitem e garantem que a principal marca da ciência seja o rigor" (CHAUÍ, 2012, p.275).

Schwartz (1971, p.28) aponta que a visão científica ou ciência teórica, ou seja, "[...] a transferência dos problemas do homem, do reino da fé e do mito para a esfera intelectual, foi efetuada principalmente pelos gregos". Foram os filósofos daquele tempo que conceberam os alicerces do que hoje é normalmente denominado pensamento ocidental.

Os filósofos gregos formularam sistemas para explicar a existência, o universo, o homem e a sociedade. Com a rejeição da intervenção mágica, lançaram as fundações do critério científico

\footnotetext{
7 “A limitação expressa pelas palavras 'em qualquer forma ou medida' é aqui incluída para tornar a definição aplicável à ciência moderna, que não tem pretensões ao absoluto. Mas, segundo o conceito tradicional, a ciência inclui garantia absoluta de validade, sendo portanto, como conhecimento, o grau máximo de certeza" (ABBAGNANO, 2012, p.157).
} 
da interpretação da natureza. A observação dos processos técnicos e naturais juntamente com experiências rudimentares tornaram possível a incorporação dessas observações num sistema que tinha coerência lógica (SCHWARTZ, 1971, p.28-29).

Chauí (2012, p.278), afirma que, apesar dos ideais de cientificidade ${ }^{8}$ terem começado com os gregos, a concepção antiga e a concepção clássica ou moderna de ciência diferem-se bastante, especialmente em um aspecto:

A ciência antiga era uma ciência teorética, ou seja, apenas contemplava os seres naturais, sem jamais imaginar intervir neles ou sobre eles por meios técnicos; [enquanto] a ciência clássica é uma ciência que visa não só ao conhecimento teórico, mas sobretudo à aplicação prática ou técnica.

O momento, no qual a ciência deixa de ser puramente teórica e passa também a incorporar características práticas, é aqui considerado o ponto de partida para o entendimento da ideologia que transpassa tanto a sociedade tecnológica como um todo, quanto a tecnologia digital em particular. Para Horkheimer (1976), a razão não apenas passa a ser um instrumento, como também passa a se abster de qualquer preocupação com questões teóricas e conceituais. Para entender esse movimento ele faz uma análise detalhada sobre a transformação da racionalidade, com o intuito de decifrar a natureza que ela adquiriu na cultura industrial contemporânea.

Para entender a argumentação de Horkheimer (1976, p.11-12) é importante diferenciar entre dois tipos de razão: a subjetiva e a objetiva. A razão subjetiva está relacionada com a "[...] faculdade de classificação, inferência e dedução, não importando qual o conteúdo específico dessas ações: ou seja, [trata sobre] o funcionamento abstrato do mecanismo de pensamento". A razão objetiva diz respeito à "[...] existência da razão não só como uma força da mente individual, mas também do mundo objetivo: nas relações entre os seres humanos e entre classes sociais, nas instituições sociais e na natureza e suas manifestações". De forma simplificada, podese afirmar que, em se tratando de meios e fins (procedimentos e propósitos), enquanto a primeira considera os meios, a segunda tem como objetivo o entendimento dos fins.

\footnotetext{
8 Chauí (2012, p.277) descreve três ideais de ciência que podem ser observados historicamente: racionalista (dos gregos ao final do século XVII), empirista (de Aristóteles até final do século XIX) e construtivista (a partir do século XX). O ideal racionalista "afirma que a ciência é um conhecimento racional dedutivo e demonstrativo como a matemática, portanto, capaz de provar a verdade necessária e universal de seus enunciados e resultados, sem deixar nenhuma dúvida". 0 ideal empirista "afirma que a ciência é uma interpretação dos fatos baseada em observações e experimentos que permitem estabelecer induções e que, ao serem contempladas, oferecem a definição do objeto, suas propriedades e suas leis de funcionamento". 0 ideal construtivista "considera a ciência uma construção de modelos explicativos para a realidade e não uma representação da própria realidade".
} 
O que Horkheimer (1976) descreve é uma passagem gradual. Sumarizando esta sua análise histórica da relação entre estes dois tipos de razão e da predominância de seu componente objetivo na Grécia, a sociedade industrial passa a incorporar a razão subjetiva como único meio válido de conhecimento, por mais que ainda almejasse o conhecimento das coisas, ou seja, o conhecimento objetivo. Assim, aquilo que, a partir do Séc. XIV, começou como um esforço para superar os credos e a dominação da Igreja, concretizou-se, a partir do Séc. XVII, como o fim do emprego da razão objetiva enquanto estratégia válida e necessária de reflexão.

O autor coloca que, justamente, a disputa entre filosofia e religião - para se afirmarem como meio de formular e fundamentar a verdade - foi o que culminou na neutralização de ambas. Acerca dessas considerações, acrescenta que:

Os filósofos do Iluminismo atacaram a religião em nome da razão; e afinal o que eles mataram não foi a Igreja mas a metafísica e o próprio conceito de razão objetiva, a fonte de poder de todos os seus esforços. A razão como órgão destinado a perceber a verdadeira natureza da realidade e determinar os princípios que guiam nossa vida passou a ser considerada como obsoleta. Especulação é sinônimo de metafísica, e metafísica é sinônimo de mitologia e superstição (HORKHEIMER, 1976, p.26).

Com a anulação da validade daqueles esforços empregados com o objetivo de dar um significado para a existência do homem e para o mundo, o princípio abstrato do interesse individual conquistou, gradativamente, o primeiro plano, tornando-se também o núcleo da ideologia oficial da sociedade ocidental. E assim, “[...] tendo cedido em sua autonomia, a razão tornou-se um instrumento" (HORKHEIMER, 1976, p.28). Essa transformação da razão é acompanhada de uma mudança também gradual na função do conhecimento e no objetivo da vida. Uma vez que indagar sobre o significado das coisas remetia, necessariamente, a conceitos ambíguos e abstratos, a ciência passa a valorizar a cada dia mais seu caráter prático, que necessita apenas da razão subjetiva para se realizar.

Assim, para complementar a análise aqui proposta, resta então indagar para qual finalidade serve este instrumento, já que não se aspira mais ao desenvolvimento de valores humanos, à satisfação intelectual ou mesmo à investigação acerca de conceitos tais como verdade, felicidade e justiça. Na análise de Schwartz $(1971$, p.36) este foi o espaço preenchido pelo ideal de progresso.

A idéia do progresso recebeu o seu maior impulso do racionalismo, quando se julgava ter entronizado a razão, e foi alimentada por uma civilização industrial que vê o progresso tanto como uma justificação de sua existência quanto como uma fonte de esperança para o aperfeiçoamento humano. 
A palavra progresso, segundo Abbagnano (2012, p.936), designa dois sentidos. De uma maneira mais genérica, refere-se a "[...] uma série qualquer de eventos que se desenvolve em sentido desejável". Nesta definição, a palavra é sempre relacionada com algo que progride ou que avança, por exemplo, o progresso da ciência, da técnica ou do conhecimento. Com este significado o termo "[...] não dá origem a problemas e acha-se em toda parte". No segundo sentido, continua o autor, a palavra é utilizada isolada, fala-se estritamente sobre o progresso. Aqui o termo designa "[...] a crença de que os acontecimentos históricos se desenvolvem no sentido mais desejável, realizando um aperfeiçoamento crescente".

Enquanto o primeiro sentido foi empregado desde a antiguidade clássica, o segundo começou a surgir apenas no Séc. XVII, mesma época em que a razão subjetiva passou a dominar a forma na qual o conhecimento era produzido. Até então, "[...] a concepção geral que os antigos tiveram da história foi a de decadência, a partir de uma perfeição primitiva (idade do ouro), ou de ciclo de eventos, que se repete identicamente sem limites" (ABBAGNANO, 2012, p.937). Schwarz (1971, p.31) toma como exemplo o discurso de Francis Bacon para ilustrar a transformação da finalidade da ciência:

O objetivo principal do conhecimento para Francis Bacon, como para a maioria dos outros precursores da escola de progresso científico ${ }^{9}$, era a meta utilitária de melhorar a condição do homem, diminuindo-lhe o sofrimento e aumentando-lhe a felicidade. Deixando de lado a opinião dos filósofos gregos segundo os quais o conhecimento traz sua própria satisfação intelectual, Bacon definiu a verdadeira finalidade das ciências como a de 'dotar a vida humana de novas invenções e riquezas'.

Neste sentido, a idéia do progresso designa tanto uma análise do passado quanto um prenúncio para o futuro. Parte do princípio de que o conhecimento é acumulado, gradativamente, e tem sempre como objetivo um futuro melhor e mais desenvolvido, já que, à medida que o tempo passa, mais coisas foram vividas, experienciadas e aprendidas. A seguir vale apontar quatro pressupostos que dão suporte à essa noção de progresso na história das civilizações:

1. 0 curso dos eventos (naturais e históricos) constitui uma série unilinear; 2 . Cada termo desta série é necessário no sentido de não poder ser diferente do que é; 3 . Cada termo da série realiza um incremento de valor sobre o precedente; 4. Qualquer regressão é aparente e constitui a condição de um progresso maior (ABBAGNANO, 2012, p.937).

${ }_{9}^{9}$ Outros precursores desta escola compreendem Copérnico, Kepler, Galileu, René Descartes e Newton. 
Para complementar, vale destacar que esta série linear trata-se de um movimento retilíneo indefinido, porém que culmina, especificamente, na cultura ocidental ${ }^{10}$. Seguindo este raciocínio, ao pensar os estágios (termos) como necessários, fica implícito que as regras e o curso já estão determinados, o que torna o processo histórico algo inevitável de acontecer da forma como acontece, o que pode levar à conclusão que toda ação torna-se inútil. Essa idéia determinista é enfatizada com inclusão das "regressões" como parte do processo, como se a história realmente avançasse segundo leis próprias. Por fim, se o pressuposto é o de que cada passo significa um incremento de valor, torna-se desnecessário avaliar o que é o valor. Afinal, o incremento torna-se valor por si mesmo - mais é sempre melhor.

Elucidados os princípios do tipo específico de razão, que é utilizado como instrumento para o progresso, e qual é o lugar que o progresso ocupa no pensamento moderno, torna-se explícito o entrelaçamento dessas questões. Pode-se dizer, que o "casamento" entre razão (subjetiva), ciência e progresso, foi o responsável por grande parte do desenvolvimento tecnológico e social observado no século XX. Um fato, a princípio, de dado incontestável. Dentre os produtos deste avanço, destaca-se a tecnologia digital que incorpora e infiltra no senso comum grande parte das idéias exploradas até este momento.

\subsubsection{Tecnologia digital como símbolo do progresso}

Segundo Santos (1987, p.14), no que se refere à ciência moderna, não se trata de qualquer razão, mas, sim, da razão matemática, que permite o mais puro conhecimento. "A matemática fornece à ciência moderna, não só o instrumento privilegiado de análise, como também a lógica da investigação, como ainda o modelo de representação da própria estrutura da matéria". Seguindo este raciocínio, a pureza da lógica matemática livra também o homem da ignorância, da superstição e dos males sociais, permitindo, assim, o desenvolvimento de um conhecimento neutro, livre de valores e independente da moralidade e da ética.

É por meio da matemática que são elaboradas as leis naturais, que consistem em um conhecimento profundo e, acima de tudo, rigoroso da natureza. Elas são resultado tanto da tradução dos objetos em quantidades, quanto de uma sucessão de divisões e classificações feitas com o intuito de organizar e conhecer:

A divisão primordial é a que distingue entre 'condições iniciais' e 'leis da natureza'. As condições iniciais são o reino da complicação, do acidente e onde é necessário seleccionar as que estabelecem as

\footnotetext{
10 É este, por exemplo, o pensamento que valida a existência de sociedades desenvolvidas e subdesenvolvidas, sendo que (coincidentemente) as primeiras são aquelas que justamente elaboraram e difundiram a idéia de progresso.
} 
condições relevantes dos factos a observar; as leis da natureza são o reino da simplicidade e da regularidade onde é possível observar e medir com rigor (SANTOS, 1987, p.15).

Esta idéia de ordem e estabilidade do mundo, e de que estas podem ser conhecidas, transformadas em fórmulas e manipuladas para o bem humano, valida ainda mais a ciência moderna como o modelo de racionalidade hegemônica. Modelo tal que aos poucos expandiu do estudo da natureza para englobar também o estudo da sociedade $^{11}$, e que, como aponta Alcorn (1986, p.14), tem contribuído para ampliar o domínio humano em todos os âmbitos do planeta terra:

Nós evoluímos rapidamente e evoluímos externamente. Nós usamos artefatos, ou seja, construções artificiais que copiam princípios naturais, para fazer trabalhos além das mudanças físicas. E por causa dessa diferença fundamental específica, nós temos sido capazes de conquistar todos os ambientes e todas as circunstâncias que o planeta pode oferecer, desde as profundezas do oceano até o frio dos pólos. ${ }^{12}$

Alcorn (1986, p.15) justifica a tecnologia e sua importância a partir do discurso evolucionista das espécies, no qual "[...] cada espécie luta para se adequar ao ambiente no qual age para sobreviver"13. Para o autor, a tecnologia nada mais é do que a forma que os humanos encontraram para tentar ganhar essa luta e dominar a terra. E ele conseguiu isso por ter algo que nenhum outro animal tem: a habilidade de pensar abstratamente. A partir deste raciocínio, afirma que "[...] somos uma tentativa por parte da natureza de procurar uma maneira melhor, mais eficiente de fazer as coisas. Estamos um passo no caminho para a ordem. Até agora, temos sido uma experiência muito bem sucedida. ${ }^{14}$ (p.15)

É preciso muito cuidado para entender os pressupostos que balizam esse tipo de raciocínio. Como foi mencionado, esta argumentação possui seu próprio conjunto de valores e métodos. Ao concordar cegamente com discursos pautados no progresso e não colocar em dúvida a natureza da tecnologia, fica latente como os pressupostos da ciência moderna estão enraizados na maneira de pensar, e leva a crer ser a única possível, ou a única eficiente e válida. Antes de abordar os limites deste pensamento e

\footnotetext{
11 Segundo Santos (1987, p.30), “Tal como foi possível descobrir as leis da natureza, seria igualmente possível descobrir as leis da sociedade. [...] No século XVIII este espírito precursor é ampliado e aprofundado e o fermento intelectual que daí resulta, as luzes, vai criar as condições para a emergência das ciências sociais no século XIX. [...] As ciências sociais nasceram para ser empíricas".

12 Do original em inglês: We evolve rapidly and we evolve externaly. We use artifacts, that is, artifical constructs that mimic natural principles, to do the job rather than physical changes. And because of that one fundamental difference, we have been able to conquer every environment and every circumstance the planet can offer, from the depths of the ocean to the cold of the poles (ALCORN, 1986, p.14).

13 Do original em inglês: [...] each species strives to match itself to the environment within which it operates in order to survive (ALCORN, 1986, p.15).

14 Do original em inglês: [...]we are an attempt on the part of nature to look for a better, more efficient way of doing things. We are a step on the road to order. So far, we have been a very successfull experiment (ALCORN, 1986, p.15).
} 
alternativas a ele, é necessário aprofundar sobre a forma como estes princípios penetraram profundamente na sociedade contemporânea: a tecnologia digital. De certa forma, ela contribuiu ainda mais para essa hegemonia do pensamento subjetivo, já que trouxe para o senso comum estes valores.

Segundo Vassão (2008, p.19), o computador pessoal possibilitou inserir no senso comum um discurso que "[...] afirma a pré-existência da tecnologia como dado fundamental da própria tessitura do universo". Ou seja, é "[...] como se a existência de uma sociedade baseada na informação viabilizada por computadores interconectados fosse um dado a priori, um ideal a ser realizado". Ideal este, totalmente ligado às idéias de progresso e evolução, mencionados no item anterior, que consideram avançadas e desenvolvidas aquelas sociedades (e pessoas) que possuem acesso à última tecnologia, e retrógradas e subdesenvolvidas aquelas que utilizam qualquer outro tipo de lógica.

Muitas vezes, alienados da ideologia que viabiliza a tecnologia digital, aqueles que possuem acesso à ela são iludidos por seu visível poder de transformação e seu impacto imediato. Segundo Dupas (2000, p.69) são os impressionantes resultados de alguns êxitos tecnológicos que dão a eles uma auréola mágica e determinista, e os coloca acima da razão e da moral. Neste sentido, o autor completa apontando que "[...] ficamos reféns de pseudo-sucessos que não se sustentam em valores e muito menos em uma opção consciente de uma sociedade que possa definir suas prioridades de maneira amplamente democrática". Afinal, para o racionalismo científico moderno é justamente a subjetividade e seus valores agregados que devem ser evitados para garantir o desenvolvimento científico.

A matemática - especificamente a álgebra binária - é a base lógica sobre qual toda a computação digital tem sido construída. A capacidade de processamento tem aumentado e o tamanho dos componentes diminuído em uma velocidade surpreendente, e isso alimenta a idéia para o senso comum de constante mudança na tecnologia digital. Porém, enquanto não forem desenvolvidos computadores que operem sob qualquer outro tipo de lógica, que não seja a binária, pode-se afirmar que a essência da tecnologia digital continua a mesma, que ela não mudou desde que foi inventada, em meados do Século XX.

A visão desta tecnologia como neutra é, de certa maneira, consequência da premissa de que a matemática seria o único meio legítimo de atingir o conhecimento puro. De acordo com Vassão (2008, p.4), a informação, por ser produto da lógica, é, muitas vezes, considerada no discurso tecnológico como algo neutro. Assim, para aqueles que concordam com essa idéia, pode-se dizer que acreditam (mesmo sem ter ciência desta crença) também que sua pureza é, sim, sinônimo do conhecimento verdadeiro, ou 
seja, livre dos valores, dos interesses e da moral humana. Neste sentido, Postman (1992, p.124) aponta:

Na verdade, o computador torna possível a realização do sonho de Descartes de matematização do mundo. Os computadores tornam fácil converter fatos em estatísticas e traduzir problemas em equações. E ao mesmo tempo que isso pode ser útil (como no momento em que o processo revela um padrão que de outra maneira não teria sido notado), também pode ser diversivo e perigoso quando aplicado de forma indiscriminada nos assuntos humanos.

A grande questão é que a facilidade de uso dos objetos digitais, unida com sua (aparente) indiscutível funcionalidade ignora, também, toda uma cadeia de idéias e de produção. Segundo Zizek (2012, p.294):

O paradoxo, portanto, é que, quanto mais personalizado, fácil e "transparente" for o funcionamento do pequeno item (celular inteligente ou minúsculo) que tenho na mão, mais a configuração tem de se basear no trabalho realizado em outro lugar, num vasto circuito de máquinas que coordenam a experiência do usuário; quanto mais essa experiência é não alienada, mais é regulada e controlada por uma rede alienada.

Assim sendo, vale questionar até que ponto esta tecnologia liberta e até que ponto ela contribui mais ainda para a alienação das pessoas.

Uma outra premissa importante que é reafirmada pela computação digital é a da real existência das dualidades, uma idéia amplamente sustentada pelo pensamento moderno que, insistentemente, separa o homem da natureza, a mente do corpo, o bom do mau, o superior do inferior, etc. Para Vassão $(2008$, p.9), as metáforas, aproximações e analogias que são utilizadas para tornar o computador acessível são baseadas, ao mesmo tempo que reforçam estas distinções, diminuindo, ainda mais, o espaço para seu questionamento.

Essa precedência sócio-cultural do software indica a atualização da dicotomia entre corpo (hardware) e mente/espírito (software). Ela afirma continuamente a maior importância sócioculturalmente investida em uma entidade que é, na maioria dos discursos, descrita como imaterial, afeita ao espírito, ao pensamento, à cultura, à sensibilidade, e coloca em um patamar justificadamente inferior a parcela material, maquinal, técnica, corporal. (VASSÃO, 2008, p.9)

A partir de uma explicação física, por mais que se trate da passagem ou não de energia em fios, cabos e circuitos, convencionou-se a diferenciação entre o que é reprogamável (software) e o que é fixo (hardware). Para aqueles que conhecem um 
pouco mais a essência do computador digital, fica difícil (quando não impossível) fazer esta distinção. Sem um meio para existir, o software não existe. Ele é nada mais que um agenciamento de circuitos pelos quais transitam pequenos pulsos de energia (chamados de energia discreta).

Essa idéia é completamente estranha para grande camada da população, cujas vidas são totalmente influenciadas pela computação, mesmo sem saber exatamente do que se trata. Inclusive, não é raro o caso de programadores que não possuem idéia de como um circuito eletrônico funciona. A grande questão que se coloca é até que ponto as interfaces amigáveis amplamente utilizadas no campo computacional, contribuem para a alienação das pessoas, fazendo com que elas, assim, reproduzam um sistema ou modo de pensar sem saber exatamente as implicações que isso pode trazer. Nesta pesquisa, estas perguntas são feitas com o intuito de instigar uma apropriação crítica da tecnologia, afinal, como aponta Dupas (2000, p.16):

\footnotetext{
Não se trata de ir contra o desenvolvimento tecnológico, adotando um posicionamento reacionário. A questão é bem outra: a tecnologia pode e deve se submeter a uma ética que seja libertadora a fim de contemplar o bem estar de toda a sociedade, presente e futura, e não apenas colocar-se a serviço de minorias ou atender necessidades imediatas.
}

Vale ressaltar que a idéia, aqui discutida, não é a de ser contra o desenvolvimento tecnológico, até porque a arquitetura interativa pressupõe sua existência. Trata-se de nunca deixar de se fazer perguntas sobre seus custos, suas limitações e sobre a possibilidade de resolver os problemas de outras maneiras, a partir de outros pressupostos, lógicas e métodos.

\subsubsection{Os limites da sociedade tecnológica}

Se o progresso vai resultar em uma vida melhor para as gerações futuras, não é possível afirmar. Entretanto, apesar da grande evolução da ciência e da melhoria de vários aspectos da vida, vários são os indícios de sua limitação e de sua natureza estranha, isso não pode ser negado. A crueldade das duas guerras mundiais e a atual crise ambiental são exemplos frequentemente utilizados para ilustrar o lado perverso da sociedade moderna. Diante de tais acontecimentos, torna-se imperativo ao menos colocar em dúvida esse ideal de civilização e progresso que, depois de 300 anos em voga, foi capaz de justificar, dar suporte e se desenvolver às custas de tal destruição e crueldade.

Em uma primeira análise, estes acontecimentos são suficientes para apontar a existência de facetas antagônicas na sociedade tecnológica. Porém, para apresentar uma percepção aprofundada, é necessário um esforço no sentido de desvendar 
possíveis aspectos contraditórios que deram origem a essas discrepâncias. Para exercitar esse ponto de vista, três aspectos serão aqui tratados.

O primeiro diz respeito à natureza do progresso que, como aponta Bury (1921), aproxima-se mais da categoria de dogma do que de um objetivo concreto a ser alcançado. O segundo questiona a ambiguidade do pensamento científico que, ao pretender explicar toda a realidade se esquece do caráter parcial de seu próprio método. $O$ terceiro aspecto aborda a posição de alienação do homem em relação à sua própria razão, ou seja, de não compreender que aquilo que ele cria é, exatamente, o que o destrói.

Conceitos tais como liberdade, tolerância e igualdade, segundo Bury (1921), diferemse categoricamente daqueles tais como destino, providência divina e renascimento. Os primeiros estão ligados às aspirações e ações humanas, sendo que as análises sobre estes temas questionam suas qualidades enquanto bons ou ruins, úteis ou perversos. Os segundos fazem referência aos mistérios da vida independentemente da vontade humana, e a questão que se levanta relaciona-se com sua existência ou inexistência.

Por meio de uma análise detalhada de como a idéia de progresso histórico penetrou no pensamento moderno, Bury demonstra porque esta se encaixa na segunda categoria e, sendo assim, só é válida enquanto objetivo de vida na forma de um dogma, ou seja, imposta como uma doutrina verdadeira e incontestável. No final, trata-se de acreditar ou não na sua existência. Assim, explica Bury (1921, p.2),

Nós, agora, tomamos tanto como dado, nós estamos tão conscientes do constante progresso no conhecimento, nas artes, na capacidade de organização, nos serviços de todos os tipos, que é fácil olharmos para o Progresso como um objetivo, tal como a liberdade ou uma federação mundial, que apenas depende dos nossos próprios esforços e boa vontade para alcançar. Mas, por mais que todo o aumento de poder e conhecimento dependa do esforço humanos, a idéia de Progresso da humanidade, da qual todos esses progressos específicos derivam seu valor, levanta uma questão definitiva de fato, que os desejos ou o trabalho do homem não podem afetar, mais do que os seus desejos ou seu trabalho pode prolongar a vida além-túmulo. 15

Para o autor, por mais que a acumulação de conhecimento seja nítida, não há como ter certeza de que esta esteja direcionada para uma direção desejada. Até porque,

\footnotetext{
15 Do original em inglês: We now take it so much for granted, we are so conscious of constantly progressing in knowledge, arts, organizing capacity, utilities of all sorts, that is easy to look upon Progress as an aim, like liberty or a worlds-federation, which it only depends on our own efforts and good-will to achieve. But though all increases of power and knowledge depend on human effort, the idea of Progress of humanity, from which all these particular progresses derive their value, raises a definite question of fact, which man's wishes or labors cannot affect any more than his wishes or labors can prolong life beyond the grave. (BURY, 1921, p.2)
} 
"[...] a fim de julgar se estamos nos movendo em uma direção desejável, teríamos de saber exatamente qual é o destino"16 (BURY, 1921, p. 2). Entretanto, a idéia de progresso na sociedade moderna pressupõe, como já mencionado, um avanço indefinido para o futuro, de forma que não há nada a ser alcançado a não ser cada dia mais avanço. A suposição de que existe um "progresso absoluto", que quando alcançado levará à felicidade dos homens na terra, pode ser comparada como uma versão terrena da profecia cristã que prevê a ida das boas almas ao paraíso.

Sobre essa perspectiva, Schwartz $(1971$, p. 23) coloca que a crença no progresso nada mais é do que uma "[...] fé que destronou a fé". A grande diferença é que, na ciência moderna, o homem não se dirige mais a Deus, e, sim, aos seus próprios imperativos, em especial, àquele que dá a ordem de ocupar e dominar a terra. A esse respeito complementa:

A ciência pretende ser livre de valores e, todavia, estabeleceu-se como o valor supremo da civilização ocidental. Um forte establishment científico é considerado a base de todo o poder: militar, industrial e intelectual. As escolas e universidades estão atreladas ao carro de guerra da ciência. Os negócios e a economia estão se tornando disciplinas científicas na sua procura de ordem e eficiência. Toda a humanidade é orientada para técnicas à imagem da ciência (SCHWARTZ, 1971, p.45-46).

Até certo ponto, o fato de que a ciência exerce uma grande influência no pensamento e na vida humana, não apresenta nenhum problema. O problema passa a existir, quando esta adquire uma posição totalitária, ou seja, "[...] na medida em que nega o caráter racional a todas as formas de conhecimento que não se pautarem pelos seus princípios epistemológicos e pelas suas regras metodológicas" (SANTOS, 1987, p.11).

Por um lado, os princípios sobre os quais o conhecimento científico é construído excluem automaticamente, tanto aqueles problemas que não podem ser resolvidos, quanto os resíduos deixados por suas soluções. Por outro, seus métodos não incluem estratégias de autoreflexão, e como consequência tomam como irrelevante seu caráter parcial e dão, como certo, sua objetividade (ou a ausência de valores).

Schwartz (1971, p.66) aponta que "[...] uma solução tecnológica é sempre uma quasesolução porque dá origem a um resíduo de problemas não resolvidos". Segundo o autor, isso acontece, pois, os problemas a serem resolvidos são normalmente considerados isolados, por mais que pertençam a um sistema aberto. Quando a solução é analisada novamente dentro de um sistema maior, ela deixa de ser completa, já que, neste momento, "[...] descobre-se quase sempre que a solução do

\footnotetext{
16 Do original em inglês: [...] in order to judge that we are moving in a desirable direction we should have to know
} precisely what the destination is (Bury, 1921, p. 2). 
problema específico engendrou uma série de novos problemas decorrentes das interrelações e das características finitas do sistema fechado".

Como consequência, o processo tecnológico cai em um círculo vicioso no qual "[...] o resultado de cada desenvolvimento é mais desenvolvimento, e o de toda pesquisa é mais pesquisa" (SCHWARTZ, 1971, p.55). Isso faz com que a obsolescência apareça como um resultado inerente: novas soluções, atualizações e versões são sempre melhores e necessárias.

Uma vez que o senso comum passa a acreditar no sucesso da ciência, sem ter conhecimento de uma perspectiva mais ampla da situação, sua importância passa a perpetuar a partir da idéia de que sempre mais tecnologia é necessária para solução dos novos problemas. O que é deixado de lado pelos meios de divulgação científica (formais e informais), por mais que o caráter metódico da ciência confira a ela um aspecto autônomo, é que existe muito espaço em seu processo para a inclusão de valores, interesses e ideologias.

A ênfase dada às soluções e aos avanços mascara tanto os problemas residuais, quanto seu forte caráter subjetivo. "As disciplinas técnicas são influenciadas por tradições e interesses e, geralmente, contêm erros, apesar de todos os esforços de especialistas em depurá-los" (FEENBERG, 2013, p.6). É o que Schwartz (1971, p.54) também pondera ao declarar que,

Em considerável extensão, portanto, o processo tecnológico é um processo social que depende de outros aspectos da ciência e da tecnologia relacionados com qualquer problema dado e está sujeito a óbices, muitos do quais socialmente determinados. Pode fazer-se uma tentativa de formular esses óbices por meio de outros processos tecnológicos; entretanto, os critérios fundamentais dessas formulações são humanos e sociais e não tecnológicos. Desde que esses critérios se baseiam em considerações metafísicas, é a uma metafísica fraca e não a uma tecnologia autônoma que se deve culpar pelos excessos do processo tecnológico.

Se considerada a análise de Horkheimer (1976, p.12) sobre o império da razão instrumental (subjetiva) na sociedade moderna, ficam claros os motivos que tornam inviáveis a reflexão sobre o porquê das coisas. "Se essa razão se relaciona de qualquer modo com os fins, ela tem como certo que estes também são racionais no sentido subjetivo, isto é, de que servem ao interesse do sujeitos quanto à autopreservação". Ou seja, se a finalidade é prática, não carece de reflexão, só o fato de ter uma função definida e de se encaixar nos métodos deste tipo de investigação faz com que ela seja válida. É como se a ciência fosse um aparato de olhar as coisas, porém separada do mundo: além de ela se considerar o único meio pelo qual o mundo pode ser 
contemplado, ela não se reconhece como uma coisa e, assim, não volta o olhar para si mesma.

A ciência moderna, tal como os positivistas a entendem, se reporta essencialmente sobre fatos, e portanto pressupõe a reificação da vida em geral e da percepção em particular. Contempla o mundo como um mundo de fatos e coisas, e deixa de relacionar a transformação do mundo em fatos e coisas com o processo social (HORKHEIMER, 1976, p.92).

Assim, o autor dá um passo a mais em sua reflexão ao incluir aquele que observa. Se a ciência é um objeto flutuante, ela não flutua sozinha: inclui um comandante. Para ele, fica claro que a concepção de uma ciência que reduz a realidade a objetos de investigação é produto de um homem que se coloca assim em relação à vida e à natureza. É o homem e não a ciência que enxerga a natureza como uma presa, algo exterior que deve ser dominado. Ele não reconhece e aceita sua própria finitude e, como complementa Feenberg $(2013$, p.1) “[...] a tecnologia dá a ilusão de poder tal qual o poder de deus. Acreditamos poder controlar a natureza e submetê-las aos nossos desejos".

Deste modo, a ciência pode ser também entendida como a formalização da renúncia do homem de utilizar sua capacidade racional de olhar para si mesmo. Afinal, como coloca Bateson (1986, p.32), “[...] aqueles que não têm a menor idéia de que seja possível estarem errados não podem aprender nada exceto conhecimento técnico". Como consequência, da mesma maneira que a ciência não se reconhece como parte do conjunto de coisas que analisa, o homem não se reconhece nos resultados de suas ações, que inclui tanto os seus avanços assim como tudo aquilo que o reprime.

De acordo com Kuhns (1971, p.253), entender que a "[...] lógica e outros ícones do racionalismo podem obscurecer da mesma maneira que podem esclarecer"17, é reconhecer seus limites e o primeiro passo para a apropriação crítica da tecnologia digital. No lugar de uma visão apologética ou apocalíptica do desenvolvimento, leva o indivíduo a lidar com a complexidade da realidade sem dogmatismo e alienação.

Para isso, é preciso colocar a ciência no seu lugar, ou seja, como uma das maneiras possíveis de perceber e de investigar a realidade. "Como um método de percepção - e isso é tudo o que a ciência pode ter a pretensão de ser - a ciência, como todos os outros métodos de percepção, está limitada em sua habilidade de recolher os sinais visíveis do que possa ser verdadeiro"(BATESON, 1986, p.36).

17 Do original em inglês: [...] logic and other icons of rationalism can obscure as much as they clarify (KUHNS, 1971, p.253) 
O perigo existe quando a ciência se confunde com a realidade ao pretender explicá-la totalmente, e quando a realidade se confunde com a ciência ao ser reduzida apenas àquilo que é explicável. Assim, para elaborar qualquer teoria ou proposta de ação, é importante ter consciência dos pressupostos, a partir dos quais os limites da razão subjetiva (instrumental) se desdobram, assunto deste tópico. Da mesma maneira, é necessário também investigar diferentes estratégias de entendimentos, estabelecidas a partir de outros pressupostos e caminhos. É neste sentido que outras razões entram no contexto deste trabalho.

\subsubsection{Outras razões}

O racionalismo científico moderno, ao pretender o conhecimento total da realidade, ou seja, a substituição do caos pela organização das coisas que existem, deixa muito a desejar. Se ele demonstrou algo, foram os perigos intrínsecos à adoção de uma razão única (e limitada) para governar a vida humana. De forma que o homem, ao se apegar a um pensamento único, abdica-se de pensar e passa a ser um mero realizador de tarefas e seguidor de receitas prontas.

Para falar de outras razões, é importante reconhecer que a experiência e a realidade, ou seja, aquilo que o homem vive, é e sempre será maior do que as explicações que podem ser oferecidas sobre elas. No entanto, assumir a limitação do que é possível conhecer traz, ao mesmo tempo, medo e lucidez. O medo decorre, em grande parte, da necessidade de reconhecimento da finitude, que não está restrita ao que é possível conhecer, mas se estende também à ação e à existência humana (FEENBERG, 2013).

A lucidez deriva da necessidade de aprofundamento. Uma vez admitida a não possibilidade de um conhecimento verdadeiro ou total das coisas, decorre-se que, a qualquer argumentação, deve anteceder-se uma explicitação dos limites, das intenções e dos propósitos do que vai ser debatido. De certo modo, este movimento impede tanto a adoção inconsciente de valores quanto a impressão de que estes são dados a priori e, por assim serem, não carecem de análise.

Mais do que elaborar outros sistemas globais e estáticos de explicação do mundo, o importante é retomar a atitude racional, ou seja, "[...] o trabalho do pensamento para apreender, compreender e interpretar o sentido das coisas, dos fatos, das ideias, ações e valores humanos" (CHAUÍ, 2012, p.106). Atitude tal, como já foi analisado, desestimulada pelo pensamento instrumental. Assim, falar sobre outras razões significa, para o contexto desta tese, investigar outros movimentos estruturados do pensamento, de forma que a própria investigação que aqui se coloca possa ser compreendida como um movimento em si. 
O pensamento de Horkheimer (1974), por exemplo, pode ser percebido como um movimento que parte de uma crítica direcionada à coerência interna da razão instrumental e vai até a reintrodução do que ela exclui enquanto razão válida. Inicia seu raciocínio com a diferenciação entre razão subjetiva e razão objetiva, analisa por que e como o pensamento científico descarta a segunda, e, após isso, define os dois tipos de razão não como opostas, mas, sim, como complementares e, consequentemente, necessárias. A análise da complementariedade daquilo que se pressupõe diferente e antagônico é uma das principais contribuições de Horkheimer (1974) para este trabalho.

Nesta perspectiva, continua o autor, um esforço autocrítico da razão engloba a compreensão tanto da separação quanto da interrelação. A separação pode ser vislumbrada, a partir do excesso de cada um dos conceitos: dentre outros desdobramentos, o abuso da razão subjetiva pode levar a um materialismo vulgar e ao niilismo, enquanto a razão objetiva, em demasia, pode conduzir à alienação da realidade material, à defesa de significados que se revelam ilusórios ou mesmo à criação de ideologias reacionárias. A interrelação reside no entendimento de que "[...] os dois conceitos estão entrelaçados, no sentido de que as conseqüências de cada um não só dissolvem o outro como também conduz de volta ao outro". Assim sendo, a oposição é apenas uma aparência, mas que se faz necessária para o exercício do espírito crítico, cuja tarefa "[...] não é jogar teimosamente um contra o outro, mas promover a crítica recíproca dos dois conceitos, e assim, se possível, preparar na esfera intelectual a conciliação dos dois na realidade" (Horkheimer, 1974, p.185-186).

Entre as observações de Santos (2007) um movimento diferente pode ser identificado, de forma que sua crítica inicial encontra-se no âmbito da coerência externa da razão instrumental. Para Chauí (2012, p.107) , falar em coerência externa implica o seguinte movimento:

[Examinar][...]se um pensamento ou uma teoria contribuem ou não para que os seres humanos conheçam e compreendam as circunstâncias em que vivem, contribuem ou não para alterar situações que os seres humanos julgam inaceitáveis ou intoleráveis, contribuem ou não para melhorar as condições em que os seres humanos vivem.

Santos (2007, p.25) afirma que sua análise é construída a partir da incoerência do modo ocidental de abordar, entender e agir no mundo, ou seja, faz uma crítica profunda à ideologia cientificista eurocêntrica. $E$ a faz, inicialmente, a partir da análise da racionalidade hegemônica nesta sociedade, que ele descreve como indolente e preguiçosa, já "[...] que se considera única, exclusiva, e que não se exercita o suficiente para poder ver a riqueza inesgotável do mundo". 
Seu movimento, segundo o autor, parte da identificação de duas formas de manifestação desta razão indolente que considera importantes para entender suas limitações intrínsecas e, quem sabe até, superá-las. A primeira está ligada ao reducionismo próprio a esta forma de pensar, que, ao considerar irrelevante o que não é capaz de lidar acaba contraindo o que existe, ou seja, o tempo presente. A segunda está ligada à crença em um progresso e desenvolvimento infinitos, o que em sua análise expande demais o futuro. Sua elaboração aponta a necessidade de movimentos opostos, ou seja, da ampliação do presente e da contração do futuro (SANTOS, 2007).

A contração do futuro é possível pela substituição deste infinito homogêneo do progresso eterno pela estudo e consideração daquilo que o autor denomina utopias realistas, "[...] suficientemente utópicas para desfiar a realidade que existe, mas realistas para não serem descartadas facilmente". A Sociologia das Emergências, neste sentido, ocupa-se em dar sentido aos "[...] sinais, as pistas, latências, possibilidades que existem no presente e que são sinais do futuro, que são possibilidades emergentes e que são 'descredibilizadas' porque são embriões, porque são coisas não muito visíveis" (SANTOS, 2007, p.37). O ponto de partida seria, por exemplo, a ampliação simbólica de pequenos movimentos sociais e ações coletivas.

O caminho para a ampliação do presente parte da elaboração de uma Sociologia das Ausências, que "[...] tente mostrar que o que não existe é produzido ativamente como não-existente, como uma alternativa não-crível, como uma alternativa descartável, invisível à realidade hegemônica do mundo" (SANTOS, 2007, p.28-29). Esta seria responsável por instituir a superação do que o autor considera como os cinco modos de produção de ausências, ou seja, as cinco monoculturas ${ }^{18}$ responsáveis pela contração do presente, que faz com que tudo o que é ignorante, residual, inferior, local e improdutivo não seja válido ou digno de ser levado em consideração. A Sociologia das Ausências ocupar-se-ia, assim, daquilo que o pensamento hegemônico descarta e, a partir daí, criaria seus modos de produção que substituiria as monoculturas pelas ecologias.

As cinco ecologias propostas por Santos (2007) criam a possibilidade das experiências ausentes tornarem-se presentes. 1) A ecologia dos saberes, parte do emprego contrahegemônico da própria ciência, usando seus instrumentos metodológicos para

\footnotetext{
18 Os cinco modos de produção de ausênica, para o autor, são: 1) a monocultura do saber e do rigor, na qual "o único saber rigoroso é o saber científico" ; 2) a monocultura do tempo linear, na qual "a história tem um sentido, uma direção, e de que os países desenvolvidos estão na dianteira" ; 3) a monocultura da naturalização das diferenças, que ocultam hierarquias ao assumir que ela é consequência da inferioridade natural; 4) a monocultura da escala dominante, na qual o valor legítimo é o do domintante e a "realidade particular e local não tem dignidade como alternativa crível a uma realidade global e universal"; 5) a monocultura do produtivismo capitalista, na qual "o crescimento econômico e a produtividade da mensurada em um ciclo de produção determinam a produtividade do trabalho humano e da natureza, e tudo o mais não conta" (SANTOS, 2007, p. 29-30-31).
} 
dialogar com outros saberes (laico, popular, indígena etc.). O objetivo é sempre "[...] conhecer o que determinado conhecimento produz na realidade"; 2) A ecologia das temporalidades parte do princípio de que "[...] embora haja um tempo linear, também existem outros tempos". 3) A ecologia do reconhecimento incluiria "[...] descolonizar nossas mentes para poder produzir algo que distinga, em uma diferença, o que é hierarquia e o que não é"; 4) A ecologia da 'transescala' "[...] constitui a possibilidade de articular em nossos projetos escalas locais, nacionais e globais"; 5) A ecologia das produtividades consiste na "[...] recuperação e valorização dos sistemas alternativos de produção, das organizações operárias [...] etc., que a ortodoxia produtivista capitalista ocultou ou desacreditou" (SANTOS, 2007, 33-35-36).

A idéia de Santos (2007, p.39-43), parece produzir um contexto em que tudo é válido, e no qual o rigor e objetividade são descartados, mas não é esta sua intenção. Admite que sua estratégia irá criar muito mais realidade válida do que existe hoje e que esta será muito mais rica, fragmentada e caótica. Ao mesmo tempo não descarta os meios hegemônicos, já que "[...] não podemos pensar no novo senão com os conceitos do velho, da linguagem, do que temos, e ainda, quando queremos nomear coisas novas, devemos fazê-lo a partir de coisas que são velhas. Para isso, propõe o que denomina 'procedimento de tradução' para criar "[...] inteligibilidade recíproca no interior da pluralidade, que consiste em "[...] traduzir saberes em outros saberes, traduzir práticas e sujeitos de uns aos outros, é buscar inteligibilidade sem 'canibalização', sem homogeneização".

Esse procedimento de tradução é um processo pelo qual vamos criando e dando sentido a um mundo que não tem realmente um sentido único, porque é um sentido de todos nós; não pode ser um sentido que seja distribuído, criado, desenhado, concebido no Norte e imposto ao restante do mundo, onde estão três quartos das pessoas. (SANTOS, 2007, p.41).

Vale ressaltar que estas reflexões sobre a coerência externa do pensamento científico moderno são extremamente relevantes. Além de desvendar a natureza colonizadora do pensamento hegemônico e as estratégias que utiliza para tal, alerta para os perigos e oportunidades daqueles que estão na condição de colonizados ${ }^{19}$, seja por outras sociedades, ideologias ou mesmo pela tecnologia digital. O que Santos (2007) propõe

\footnotetext{
19 Sobre o silêncio derivado do colonialismo ocidental e o desafio que consiste essa superação, expõe Santos (2007) que "A cultura ocidental e a modernidade têm uma ampla experiência histórica de contato com outras culturas, mas foi um contato colonial, um contato de desprezo, e por isso silenciaram muitas dessas culturas, algumas das quais destruíram. Por isso, quando queremos tentar um novo discurso ou teoria intercultural, enfrentamos um problema: há nos oprimidos aspirações que não são proferíveis. Porque foram consideradas improferíveis depois de séculos de opressão. [...] E o dilema é como fazer o silêncio falar por meio de linguagens, de racionalidades que não são as mesmas que produziram o silencio no primeiro momento. Esse é um dos desafios mais fortes que temos: como fazer o silêncio falar de uma maneira que produza autonomia e não a reprodução do silenciamento".
} 
é o deslocamento do pensamento para uma perspectiva que conjugue o hegemônico com aquelas outras culturas que ele próprio descarta.

Ao final, o mais importante é a manutenção da vigilância e da autocrítica, ou seja, fugir de qualquer tipo de razão indolente e pensar em estratégias que incluam mais debates, ao invés de negar um pertencimento em detrimento de outro, bem como analisar sempre onde cada discurso se encaixa e evitar reducionismos mascarados de verdades. Neste sentido, a idéia de conhecimento passa a se relacionar muito mais com o movimento do pensamento do que com leis gerais e imutáveis. E o conhecedor é aquele capaz de utilizar o pensamento de maneira racional, e não aquele que apenas detém (ou intenciona) uma estrutura organizada na qual se encaixe toda a realidade. Falar em outras razões significa entender mais outros trabalhos de compreensão do que criar outras estruturas para o real. Entender esse movimento é o que previne o monopólio de razões específicas, ao mesmo tempo em que se pressupõe leituras críticas.

Neste sentido, a avaliação do que é racional ou mesmo a criação de outras razões acontecem, não pelo cumprimento dos requisitos científicos modernos mas, sim, pelo balanço da coerência interna e externa de pensamentos. Esta abordagem a respeito do que é o conhecimento induz a adoção de pressupostos temporários, a partir dos quais teorias podem ser elaboradas e entendimentos específicos alcançados, levando sempre em consideração suas potencialidades e limitações. Mesmo que o conhecimento da verdade não seja possível, pode-se almejar a racionalização, a partir de movimentos do pensamento que potencializem suas capacidades ativas e transformadoras.

As razões analisadas, até o momento, além de fornecerem elementos para diversos temas que ainda serão tratados, estabelecem a base a partir da qual outros pensamentos serão introduzidos. O que, de certo modo, é a principal característica do contexto ideológico do início do Século XXI, ou seja, a hegemonia de um pensamento único somada à pluralidade de outras abordagens periféricas que buscam criticar, reconstruir, atualizar, contrapor, expandir e/ou incorporar outros elementos ao conhecimento. É com este contexto de idéias que esta tese dialoga.

\subsection{Contexto Tecnológico}

Segundo Ellul (1968, p.19-20), a operação técnica diferencia-se do fenômeno técnico em diversos aspectos. Enquanto a primeira "[...] engloba todo o trabalho feito com certo método tendo em vista atingir um resultado", o fenômeno pressupõe a intervenção da consciência e da razão, que faz a técnica "[...] passar para o domínio 
das idéias claras, voluntárias e raciocinadas, o que era do domínio experimental, inconsciente e espontâneo".

A interferência da razão, segundo o autor, faz surgir a conviç̧ão de que outros meios melhores e mais eficientes sempre podem ser encontrados e, a partir da medição, opera discriminações para encontrar o que é efetivamente mais eficaz. A consciência relaciona-se à visão precisa das possibilidades, "[...] faz aparecer claramente aos olhos de todos os homens as vantagens da técnica e o que graças a ela se pode fazer em determinado domínio", o que produz "[...] uma rápida e quase universal extensão da técnica". Uma vez que o fenômeno técnico impregnou nos mais diversos modos de pensar e agir do homem, manifestou-se o que é hoje denominado sociedade tecnológica (ELLUL, 1968, p.21).

Neste complexo contexto social, enfatiza-se a tecnologia digital como um de seus elementos particulares, compreendida como a encarnação exemplar da disseminação do fenômeno técnico a todos os domínios da existência. Por tecnologia digital, entendem-se os objetos técnicos dotados de sistemas microeletrônicos, capazes de converter, processar e transmitir informação digital. Posto que suas questões ideológicas já foram abordadas, é importante complementar o quadro teórico com a introdução de aspectos específicos de seu desenvolvimento. Busca-se, com isso, instituir a base para o entendimento de suas diversas manifestações, em especial aquelas diretamente relacionadas à arquitetura interativa.

A caracterização do contexto pós-guerra o qual impulsionou o desenvolvimento da tecnologia digital e as idéias, ali fomentadas, esclarecem como seus principais aspectos foram elaborados e, aos poucos, tomaram forma, culminando na massificação dos componentes microeletrônicos. Os 30 anos que sucederam a entrada do computador pessoal no mercado assinalam tanto a materialização dos ideários iniciais, quanto a incorporação de seus métodos e valores pelo senso comum. Por fim, a crescente diminuição do tamanho e o aumento de capacidade de processamento dos componentes, unidas ao seu barateamento têm culminado na extrapolação do computador pessoal e na dispersão da tecnologia digital, nos mais diversos âmbitos da vida cotidiana. Simultaneamente, no campo conceitual, podem ser identificados discursos específicos que acompanham essa disseminação com os quais a arquitetura interativa dialoga diretamente.

Estas questões são apresentadas com o objetivo de contribuir com possibilidades de diálogos entre os diferentes tópicos abordados ao longo desta tese. Uma vez que a arquitetura interativa pressupõe a incorporação da tecnologia digital, é importante compreender as principais discussões intrínsecas a este contexto específico, por mais que, ideologicamente, possuam nítidas limitações. Com isso, abre-se a possibilidade de 
ampliação da qualidade, tanto do discurso arquitetônico, fazendo que este transcenda a mera incorporação e aplicação das possibilidades tecnológicas, quanto do discurso tecnológico, incluindo nele valores que concernem à arquitetura, à cidade e à sociedade como um todo, possibilidade esta que será explorada no restante desta tese.

\subsubsection{Computadores e comunicação pós II Guerra Mundial}

Para Winston (1998), mais do que uma revolução científica ou uma nova era, o advento da tecnologia digital representa a materialização da evolução do pensamento ocidental, sobretudo dos últimos 300 anos. Apesar das enormes mudanças que podem ser identificadas, esta evolução é caracterizada por uma fundamental continuidade. Idéias que não encontraram espaço para se desenvolverem em determinados momentos, muitas vezes, foram retomadas em contextos mais propícios para sua implementação. Outras que foram deixadas inacabadas ou que indicam caminhos alternativos são constantemente aproveitadas, criticadas e adaptadas em formatos atualizados. É neste sentido que o entendimento da história e do contexto tecnológico, em seus diferentes momentos, depende da análise das necessidades e restrições sociais de cada época, e não apenas da avaliação da performance isolada de determinada tecnologia.

Assim sendo, a tecnologia digital é um desses temas cuja descrição histórica é sempre complexa e controversa, permeada de disputas, intrigas e interesses. Isso ocorre pois sua formatação é resultado da convergência de uma série de investigações paralelas que ocorreram em diferentes tempos e lugares (WINSTON, 1998). Mais do que elaborar uma história detalhada de seu desenvolvimento a partir de fatos, nomes e datas, o importante para esta tese é caracterizar a especificidade do momento no qual várias idéias começaram, efetivamente, a tomar forma e a adentrar na sociedade como um todo.

Segundo Braun e Macdonald (1982, p.26), foi o profundo caráter científico da II Guerra Mundial que alterou, significativamente, o papel da ciência na sociedade. Acerca destas considerações, vale destacar que

[...] não foram apenas as máquinas científicas que desempenharam um papel evidentemente decisivo na guerra. Os cientistas se tornaram os garotos dos bastidores, os investigadores, dos líderes militares, e esse foi o papel prático mais sinistro que eles desempenharam. Cientistas, alguns conhecidos pensadores altamente abstratos entre eles, se tornaram assessores em questões estratégicas e no processo inventaram a nova ciência da ciência operacional; o método para 
aplicar o pensamento científico na solução de problemas práticos, inicialmente operacionais. ${ }^{20}$

A guerra mobilizou a comunidade científica para a solução dos mais diversos tipos de problemas e seus feitos, apesar de estarem ligados à destruição e exterminação massificada de lugares e pessoas, contribuíram, significativamente, para a elevação da imagem da ciência. "Não mais era um passatempo para cavalheiros ou uma ocupação obscura para os inteligentes, porém inúteis. A guerra fez com que a ciência emergisse da obscuridade para o centro das atenções" ${ }^{\prime 1}$ (BRAUN; MACDONALD, 1982, p.26). Com o fim da guerra, este clima científico continuou, especialmente nos Estados Unidos, tanto para alimentar o poder bélico durante a guerra fria (WINSTON, 1998), quanto para desenvolver sua infraestrutura de informação e telecomunicação (BRAUN; MACDONALD, 1982, p.27).

A II Guerra Mundial estimulou, dentre outras coisas, o desenvolvimento de duas áreas de grande caráter científico, o cálculo automatizado e a telecomunicação. Ambas possuem raízes em teorias e experimentos anteriores à tecnologia digital. Além do ábaco, a régua de cálculo e os mecanismos diferenciais e analíticos de Charles Baggage são considerados alguns dos antecessores das máquinas computadoras (BRAUN; MACDONALD, 1982).

A transmissão e a recepção de sinais é normalmente ligada à invenção do telégrafo mas, segundo Winston (1998), a idéia de utilização de magnetismo e eletricidade para o envio de sinais foi estabelecida já no início do período moderno, no século XVIII. Diversos desenvolvimentos paralelos seguiram estes primeiros experimentos de forma que o papel do governo e do exército durante a guerra foi catalisar vários processos em andamento ao oferecer suporte, financiamento e aplicação dos resultados científicos.

A balística compreendeu uma das áreas na qual grande parte do esforço de cálculo foi aplicado. Durante a I Guerra Mundial - uma luta relativamente estática caracterizada pelas trincheiras - as trajetórias das bombas eram previstas com a utilização das tabelas de tiros. Mesmo assim, havia ainda muita adivinhação envolvida na atividade, sendo que sua eficiência era muito baixa.

\footnotetext{
20 Do original em inglês: [...] it was not only scientific hardware which played an obviously decisive role in the war. Scientists became the backroom boys, the boffins, of the military leaders, and this was the most gruesomely practical role they have played. Scientists, very well-known highly abstract thinkers amongst them, became advisers on strategic matters and in the process invented the new science of operational research; the method of applying scientific thinking to the solution of practical, initially operational, problems (BRAUN; MACDONALD, 1982, p.26).

21 Do original em inglês: No longer was it a pastime for gentlemen or an obscure occupation for the bright but useless. The war had caused science to emerge from obscurity into the limelight (BRAUN; MACDONALD, 1982, p.26).
} 
A II Guerra, com a grande quantidade de novas armas e seus alvos em movimento, exigia um cálculo muito mais dinâmico, o que elevou a necessidade de automação desta atividade para o primeiro plano. "Cada tabela de tiro para cada nova arma requeria a tabulação de dúzias de fatores sobre milhares de trajetórias possíveis, cada uma representava meio dia de trabalho para um humano computador com uma calculadora de mesa" ${ }^{22}$ (Winston, 1998, p.166). Foi o esforço nesse sentido, que culminou no desenvolvimento, pelos Estados Unidos, do ENIAC (1943-1946), a primeira máquina computadora automática (Figura 6). Esta já era digital - pois operava por meio de operações lógicas baseadas em "zero ou um" - porém não pode ser considerada um computador digital, porque fora construída com válvulas e programada com cartões perfurados.

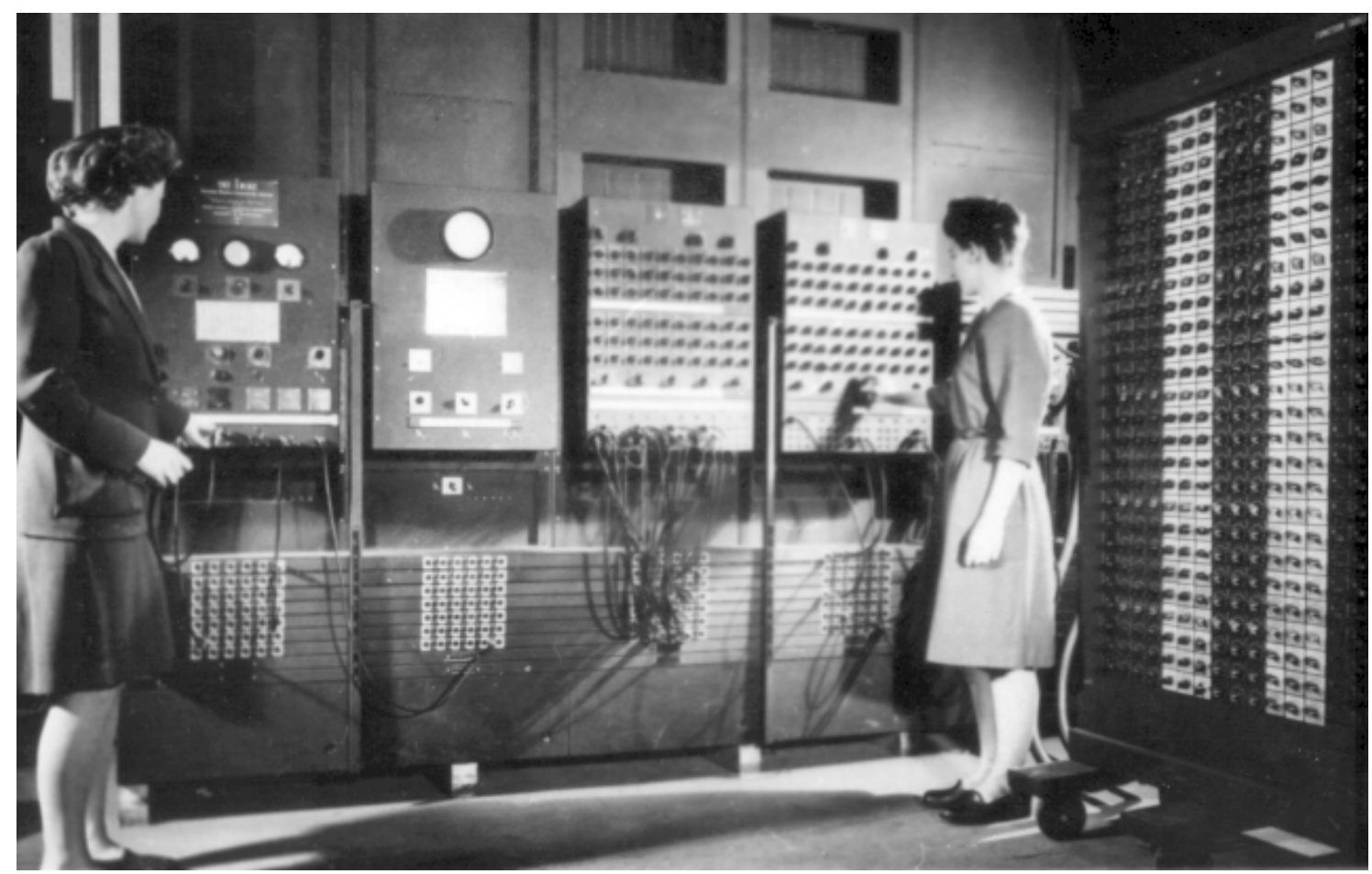

Figura 6: Duas mulheres operando o computador ENIAC - U.S. Army Photo.

(Fonte: <http://upload.wikimedia.org/wikipedia/commons/3/3b/Two_women_operating_ENIAC.gif> Acesso em: 9 Fev. 2014)

Do outro lado do oceano, a necessidade era outra, conforme Winston (1998, p. 170) “[...] desde o início das hostilidades em 1939, até meados de 1941, a Code and Cipher School (GC\&CS) do governo britânico esforçou-se para quebrar a codificação das mensagens alemãs ${ }^{\prime 23}$. A criptografia concentrou parte considerável da energia científica inglesa e o resultado foram duas versões do Colossus (Figura 7), a variante inglesa do ENIAC. Segundo Hodges (1983 apud WINSTON, 1998, p.174),

22 Do original em inglês: Each firing table for every new weapon required the tabulation of dozens of factors across thousands of possible trajectories, any of which represented half a day's work for a human computer with a desk calculator (WINSTON, 1998, p.166).

23 Do original em inglês: [...] from the outset of hostilities in 1939 until the middle of 1941, the British government's Code and Cipher School (GC\&CS) struggled to break open the encoding of German messages (WINSTON, 1998, p.170). 


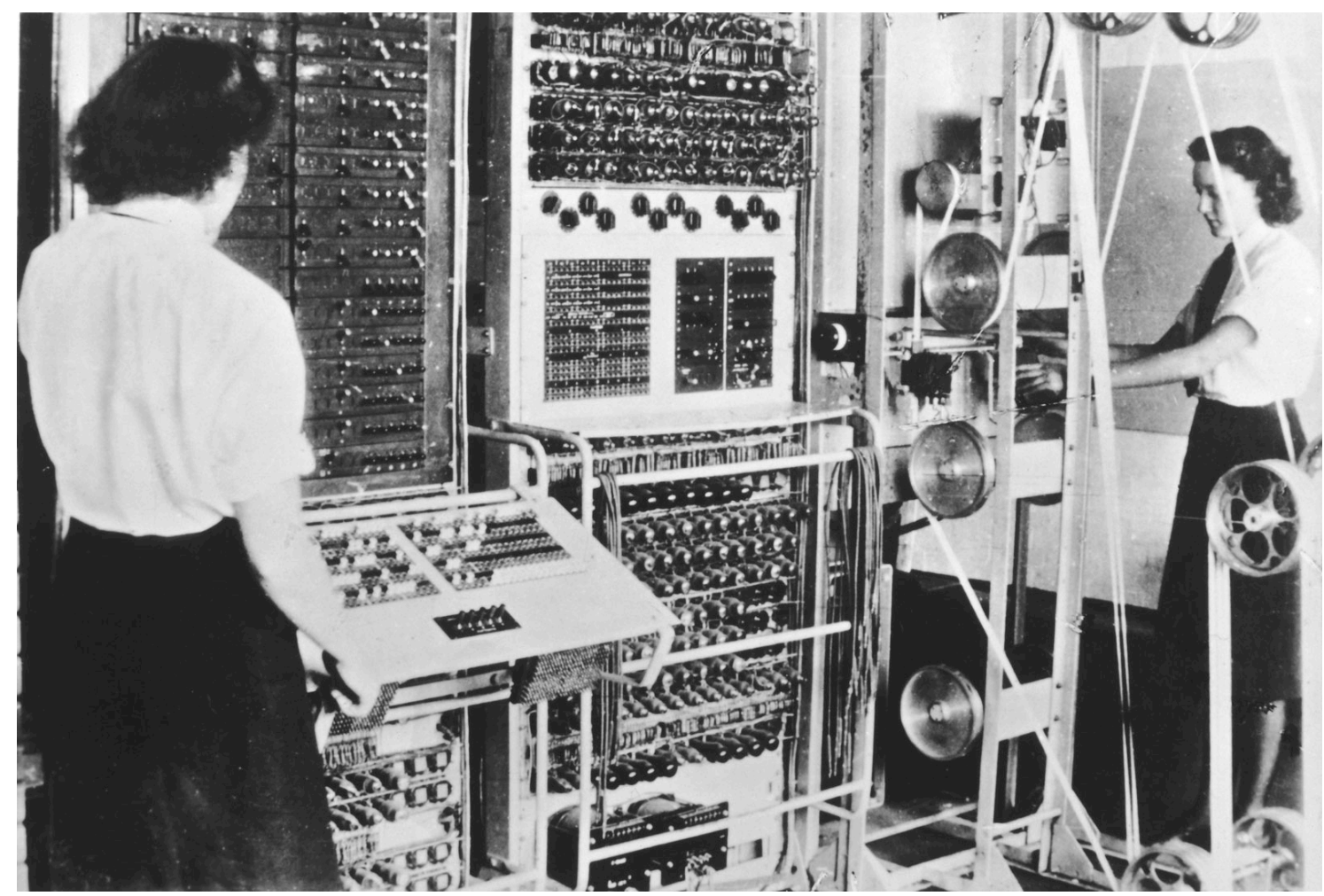

Figura 7: Computador Colossus.

(Fonte: <http://upload.wikimedia.org/wikipedia/commons/4/4b/Colossus.jpg> Acesso em: 9 Fev. 2014)

O Colossus original, reconhecendo e contando, foi capaz de produzir a melhor correspondência entre uma amostra de padrão fornecido com um texto. A nova Colossus, ao automatizar o processo de variar a amostra de padrão era capaz de decidir qual era a melhor para testar. [...] O resultado de um processo de contagem determinaria o que a Colossus faria depois. [...] Era fornecido para a Colossus um conjunto de instruções. ${ }^{24}$

As tecnologias de comunicação sem fio, dentre elas os rádios e os radares, receberam uma atenção especial neste mesmo período. Os cristais de quartzo, utilizados como osciladores em rádios para regular as frequências de emissão e recepção de sinais, exigiam métodos específicos de extração e uma precisão extrema.

Hoje, quase tudo que requer algum tipo de temporização ou controle de frequência depende de um oscilador de quartzo. Isso inclui telefones celulares, televisão em cores, computadores, relógios, tecnologia telefônica multisinal por fio, e inúmeros outros itens dos quais nossa sociedade moderna depende 25 (THOMPSON, 2007, p.2).

\footnotetext{
${ }^{24}$ Do original em inglês: The original Colossus, by recognizing and counting, was able to produce the best match of a given piece of pattern with the text. The new Colossus, by automating the process of varying the piece of pattern was able to work out which was the best one to try. [...] The result of one counting process would determine what the Colossus would do next. [...] the Colossus was provided with a set of instructions (1983 apud WINSTON, 1998, p.174).

25 Do original em inglês: Today, nearly everything that requires some type of timing or frequency control depends on a quartz oscillator. This includes cell phones, color television, computers, watches and clocks, wire-based
} 
O maior marco do período que seguiu a II Guerra Mundial foi a rapidez de implementação das idéias, resultado da cooperação entre organizações de pesquisa e desenvolvimento tanto públicas quanto privadas, indústria e departamento de defesa, especialmente nos Estados Unidos (DIZARD, 1989). A pesquisa aplicada, deste período, era acompanhada por profundas questões teóricas, que tanto fundamentaram os princípios da tecnologia digital quanto discorreram sobre suas possibilidades, delineando futuros plausíveis.

Foram vários os cientistas que participaram do desenvolvimento dos princípios lógicos incorporados pela tecnologia digital. Segundo Dizard (1989, p. 79-80), Claude Shannon abordou, dentre outras coisas, o problema matemático e lógico da informação como algo separado de seu conteúdo. Com isto, estabeleceu-se sua unidade mínima, o bit, o que tornou possível medir e avaliar a capacidade de um canal de comunicação em bits por segundo. Já Norbert Wiener, explorou o conceito de mecanismos reguladores e de controle computadorizados, que culminou na cibernética. A John von Neumann é atribuído o desenvolvimento do conceito de memória para armazenamento de programas.

Tomados em conjunto, esses conceitos mudaram a tecnologia de computação, além das funções de armazenamento e cálculo para eletrônicas, máquinas com programas-armazenamento digitais, expandindo dramaticamente suas capacidades criativas como extensores da inteligência. ${ }^{26}$ (DIZARD, 1989, p.80)

Somada às questões técnicas, a idéia de um computador como algo mais do que uma máquina de computar fez-se presente desde os primeiros experimentos com válvulas e cartões perfurados. Junto à definição do que seria essa máquina universal, Turing (1950) já descrevia a possibilidade de aprendizado que poderia ser inserida em sua programação, ao mesmo tempo em que especulava sobre uma questão que até hoje é discutida: As máquinas podem pensar?. Em relação ao caminho a ser traçado para o desenvolvimento de uma máquina inteligente, assim se colocava:

Nós podemos esperar que as máquinas eventualmente compitam com os homens em todos os campos puramente intelectuais. Mas quais são os melhores para começar? Até esta é uma decisão difícil. Muitas pessoas pensam que uma atividade bastante abstrata, tal como jogar xadrez, seria a melhor. Também pode ser sustentado que é melhor dar à máquina os melhores órgãos sensoriais que o dinheiro pode comprar, e depois ensiná-las a

multisignal telephone technology, and many other items which our modern society depends (THOMPSON, 2007, p.2).

26 Do original em inglês: Taken together, these concepts moved computer technology beyond storage and calculating functions to electronic, digital stored-program machines, expanding dramatically their creative capabilities as intelligence extenders (DIZARD, 1989, p.80). 
entender e falar inglês. Esse processo poderia seguir o ensino natural de uma criança. As coisas seriam apontadas e nomeadas, etc. Novamente, eu não sei qual é a resposta correta, mas acho que ambas as abordagens deveriam ser testadas. Nós podemos ver apenas uma pequena distância a frente, mas podemos ver bastante aí que precisa ser feito. ${ }^{27}$ (TURING, 1950, p.64)

A partir de uma outra perspectiva, Licklider (1968), já no final da década de 1950, abordou a idéia do computador não como um competidor e, sim, como um parceiro colaborativo no processo criativo. Argumentou sobre a possibilidade de uma relação simbiótica entre homem e computador. Segundo este pesquisador,

Na parceria simbiótica antecipada, o homem determinará os objetivos, formulará as hipóteses, determinará os critérios, e efetuará as avaliações. As máquinas computadores farão o trabalho rotinizável que precisa ser feito para preparar o caminho para insights e decisões no pensamento técnico e científico ${ }^{28}$ (LICKLIDER, 1968, p.1),

Vale destacar também que Engelbart (1962) dedicou parte de sua pesquisa para estudar princípios, por meio dos quais o computador interativo poderia aumentar a capacidade intelectual das pessoas. Ao explorar métodos e procedimentos para trabalhar individual e cooperativamente, abordou formas de conceitualizar, visualizar e organizar o material de trabalho. Um dos resultados das pesquisas realizadas em seu laboratório foram as workstations, compostas por display, teclado alfanumérico, mouse e um device de cinco teclas que permitiam o acesso a hierarquias estruturais de informação, com possibilidade de referência cruzada (Figura 8).

Grande parte desta pesquisa influenciou diretamente a configuração tela-mouseteclado do computador pessoal, tal como é atualmente. Entretanto, a leitura de seus textos deixa claro que a potencialidade explorada, pelo autor, vai muito além do desenvolvimento do aparato em si. Sua preocupação era, além de tornar o indivíduo mais eficiente intelectualmente, elaborar um método colaborativo de compartilhamento do conhecimento, estruturando, assim, a idéia de computadores em rede.

\footnotetext{
27 Do original em inglês: We may hope that machines will eventually compete with men in all purely intellectual fields. But which are the best ones to start with? Even this is a difficult decision. Many people think that a very abstract activity, like the playing of chess would be the best. It can also be maintained that it is best to provide the machine with the best sense organs that money can buy, and then teach it to understand and speak English. This process could follow the normal teaching of a child. Things would be pointed out and named, etc. Again I don't know what the rights answer is, but I think both approaches should be tried. We can only see a short distance ahead, but we can see plenty there that needs to be done(TURING, 1950, p.64).

28 Do original em inglês: In the anticipated symbiotic partnership, men will set the goals, formulate the hypotheses, determine the criteria, and perform the evaluations. Computing machines will do the routinizable work that must be done to prepare the way for insights and decisions in technical and scientific thinking (LICKLIDER, 1968, p.1).
} 


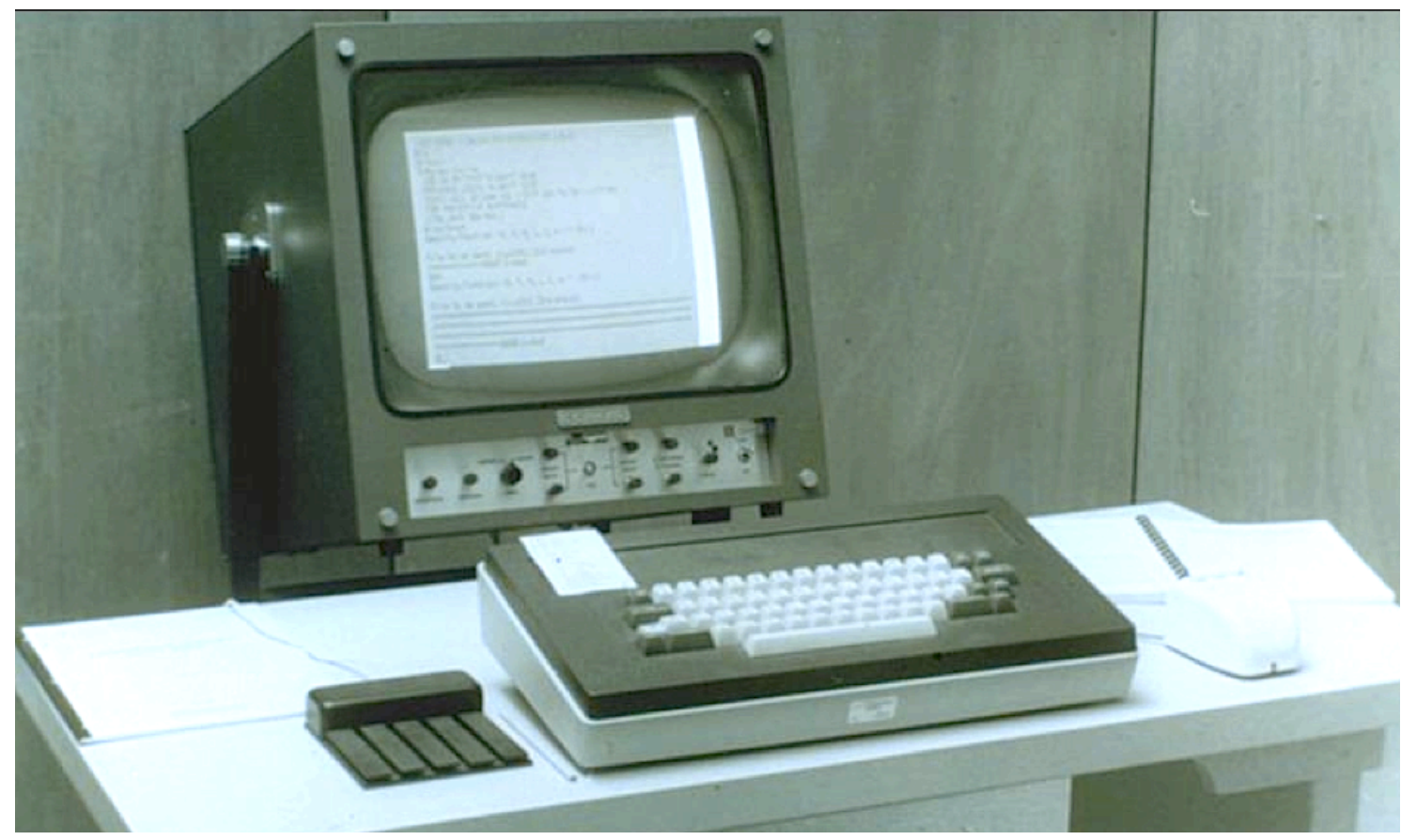

Figura 8: Estação de trabalho com mouse e teclado interativos, desenvolvida pela equipe de Engelbart (1967) (Fonte: <http://dougengelbart.org/firsts/keyset.html> Acesso em: 9 Fev. 2014)

À idéia da conexão de computadores em rede para a troca e ampliação do conhecimento soma-se a perspectiva desses enquanto meio de comunicação. Neste sentido, Licklider e Taylor (1968) incluem em seu discurso uma ênfase significativa na importância da presença das pessoas no processo comunicativo. Trata-se de encarar as pessoas como participantes de um processo em andamento, de forma que estas também acrescentam algo à troca de informações ao interagir com os computadores.

Segundo os autores, "[...] comunicar é mais do que mandar e receber. [...] Nós acreditamos que os comunicadores fazem coisas não triviais com a informação que mandam e recebem. [...] Quando mentes interagem, novas idéias emergem" ${ }^{29}$ (LICKLIDER; TAYLOR , 1968, p.21). Esta abordagem mostra o início de uma preocupação, que aumentou ao longo dos anos, com os aspectos humanos e abstratos da interação entre as pessoas com (e por meio) do computador.

A possibilidade comunicativa do computador esteve presente desde os primeiros experimentos com a lógica binária, de forma que a conformação de um sistema digital de informação tornou a convergência da computação e da comunicação inevitável. Ambas utilizam os mesmos aparatos teóricos e os mesmos componentes físicos, o que torna difícil, especialmente, durante e após a II Guerra Mundial, separar os dois desenvolvimentos. Conceitualmente, a informação digital é uma só, sendo que a mesma lógica que a processa também a transmite, assim como os mesmos componentes são utilizados para as duas atividades.

29 Do original em inglês: [...] to communicate is more than to send and to receive. [...] We believe that communicators have to do something nontrivial with the information they send and receive. [...] When minds interact, new ideas emerge (LICKLIDER; TAYLOR, 1968b, p.21). 
No que diz respeito aos componentes, por muitos anos, a válvula foi o componente chave de todo este desenvolvimento, vastamente utilizada tanto para a amplificação e conversão de sinais, quanto para a estruturação de circuitos lógicos. Porém, pesquisas sobre o comportamento elétrico de sólidos, realizadas entre as décadas de 1930 e 1940, levavam a crer que poderiam ser substituídas, um desejo justificado por várias razões.

Elas são grandes, frágeis, possuem uma vida útil relativamente curta e, pior de tudo, consome muita energia. Este último fato adiciona muito ao tamanho de qualquer instrumento que utilize valvular, pois precisa incorporar um transformador e retificadores associados e circuitos de nivelamento para prover a corrente de aquecimento para os catodos e a fonte d.c. [corrente contínua] para os anodos. Tais requerimentos são particularmente problemáticos para aparatos portáteis, tais como rádios e walkie-talkies ${ }^{30}$ (BRAUN; MACDONALD, 1982, p.24).

Por mais que na primeira metade do século $X X$, sistemas digitais de transmissão e processamento de informações tenham sido desenvolvidos e seu aparato teórico tenha avançado significativamente, pode-se dizer que a tecnologia digital, propriamente dita, apareceu apenas na segunda metade do século. Foi a partir dessa época que os circuitos lógicos passaram a ser construídos com materiais sólidos semicondutores e não com as tradicionais válvulas. $\mathrm{O}$ avanço nas pesquisas sobre 0 comportamento destes materiais culminaram no desenvolvimento do transistor em 1947 (BRAUN; MACDONALD, 1982) componente que substituiu a válvula e abriu caminho para o desenvolvimento da microeletrônica.

Com o transistor (Figura 9) , a pesquisa em semicondutores não parou de crescer e inúmeros outros componentes foram desenvolvidos. $\mathrm{O}$ agrupamento destes, em peças únicas, deu origem ao circuito integrado, disseminado ao longo da década de 1960 e responsável por uma miniaturização significativa dos circuitos microeletrônicos. Consequentemente, a segunda metade desta década foi marcada pelo aumento no número de aplicações dos circuitos, à medida que se tornava economicamente viável fazer mais coisas eletronicamente (Braun; Macdonald, 1982, p.105). A função do circuito integrado é pré-estabelecida em sua fabricação, sendo que as operações lógicas que realiza são sempre as mesmas.

\footnotetext{
30 Do original em inglês: They are large, fragile, have a relatively short working life and, worst of all, consume a lot of power. This last fact adds considerably to the bulk of any instrument using valves, because it must incorporate a transformer and associated rectifiers and smoothing circuits to provide the heating current for the cathodes and the d.c. supply for the anode. Such requirements are particularly troublesome for portable devices, such as radios and walkie-talkies (BRAUN; MACDONALD, 1982, p.24).
} 
Figura 9 (acima): Comparação entre uma válvula (1941) e a diminuição progressiva do tamanho dos transistores.

(Fonte:

$<$ http://www.c2o.pro.br/automacao/figuras/transistor2.jpg> Acesso em: 9 Fev. 2014)

Figura 10 (abaixo): Circuito integrado AMD de 1976 (Fonte:

$<$ http:/lupload.wikimedia.org/wikipedia/commons/6/6b/EPR OM_AMD_AM2716.JPG> Acesso em: 9 Fev. 2014)

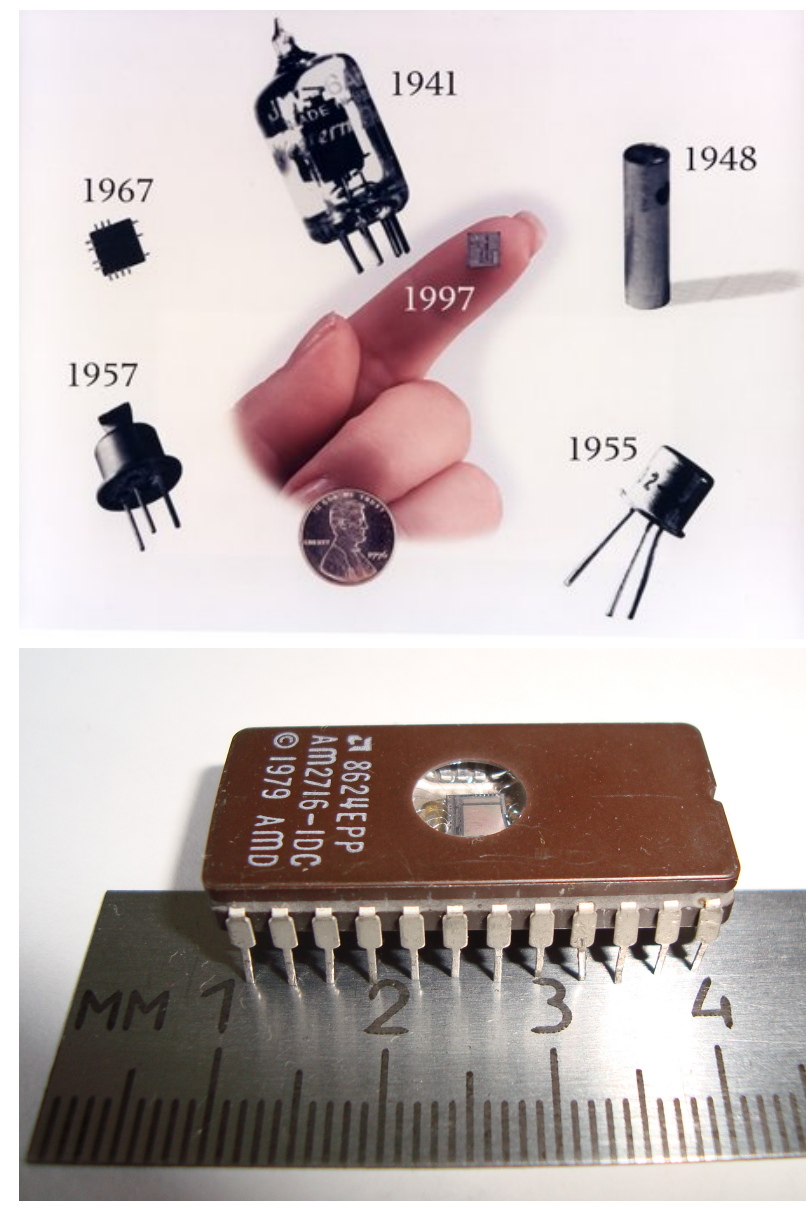

O próximo passo lógico, neste raciocínio, foi o desenvolvimento, na década de 1970, dos microprocessadores - circuitos lógicos genéricos passíveis de serem rearranjados por meio da programação, ou seja, dos softwares. Enquanto as calculadoras eletrônicas ilustram um tipo de aplicação dos circuitos integrados, os computadores pessoais só se tornaram possíveis com os microprocessadores.

As teorias e idéias elaboradas, na época da II Guerra Mundial, são extremamente relevantes ainda hoje. Dada a limitação dos recursos da época, qualquer experimento com as máquinas computadoras implicava, necessariamente, uma compreensão profunda dos fundamentos lógicos dos sistemas digitais. A maioria dos conceitos ainda são válidos, assim como grande parte dos aparatos que vieram a existir, 30 ou 40 anos depois, são derivados de idéias para aplicações elaboradas, simultaneamente, às primeiras máquinas computadoras automáticas.

O importante é perceber que, quando lidos cuidadosamente, os documentos da época apontam para muito além de onde se conseguiu chegar, e, muitos conceitos encontram-se ainda encapsulados, talvez esperando o contexto social apropriado para emergir. Para um entendimento dos limites e possibilidades da tecnologia digital, este contexto torna-se extremamente relevante, pois enquanto a tecnologia for digital sua essência permanece exatamente a mesma, apenas as aplicações evoluem. 


\subsubsection{Três décadas de computador pessoal}

Segundo Forester (1987), a partir da segunda metade da década de 1970, surgiram os primeiros kits para a montagem de microcomputadores para usuários independentes, adquiridos por engenheiros, cientistas e hobistas. Até então, os microprocessadores eram utilizados em calculadoras, temporizadores (timers) de forno doméstico, controle de processos industriais e videogames (WINSTON, p.232). Assim, gradativamente, o computador deixou de ser um objeto restrito a laboratórios e grandes corporações e passou a ocupar um espaço no cotidiano das pessoas não especialistas.

Um dos principais marcos na história do computador pessoal foi o lançamento do Apple Macintosh em 1984 (Figuras 11-12). Tratava-se de uma versão acessível do Apple Lisa do ano anterior, "[...] um sistema caro (\$9995) baseado em um chip de 32bit que exibia um controle remoto chamado de 'mouse' e imagens elementares na tela chamadas de "ícones" para facilidade de uso" ${ }^{31}$ (FORESTER, 1987, p.140). A partir do Macintosh quase três décadas já se passaram, e caracterizar cada uma dessas décadas é tanto possível quanto necessário para o escopo aqui trabalhado. Isso é feito a partir do entendimento de que esta sensação de solidez dos períodos, como se fossem blocos separados e bem delimitados, é fruto de uma percepção parcial da realidade.

Por este motivo, ressalvas são necessárias, ao se fazer este tipo de caracterização temporal. A primeira diz respeito ao seu caráter reducionista, já que se enfatiza desenvolvimentos técnicos específicos em detrimento de outras considerações também relevantes para entender o contexto maior no qual estes se deram. Em segundo lugar, qualificar determinado intervalo temporal, de acordo com desenvolvimentos técnicos específicos, não implica dizer que este fenômeno se restringe a essa época ou que sua importância diminuiu com o advento de um outro fenômeno, de forma que muitas simultaneidades podem ser identificadas. Por último, destacar um fenômeno e atribuí-lo a um espaço de tempo não significa que desenvolvimentos relacionados a ele tenham acontecido apenas naquele período, normalmente emergem de uma movimentação prévia nem sempre bem demarcada, passíveis de diversas interpretações. A ênfase no computador pessoal, e não em outros aparatos tecnológicos, é feita neste momento com o intuito de ressaltar o processo de apropriação em massa dos valores e das possibilidades que permeiam a tecnologia digital como um todo.

\footnotetext{
31 Do original em inglês: [...] a pricey (\$9995) system based on a 32-bit chip which featured a remote control device called a "mouse" and elementary pictures on the screen called "icons" for ease of use (FORESTER, 1987, p.140).
} 


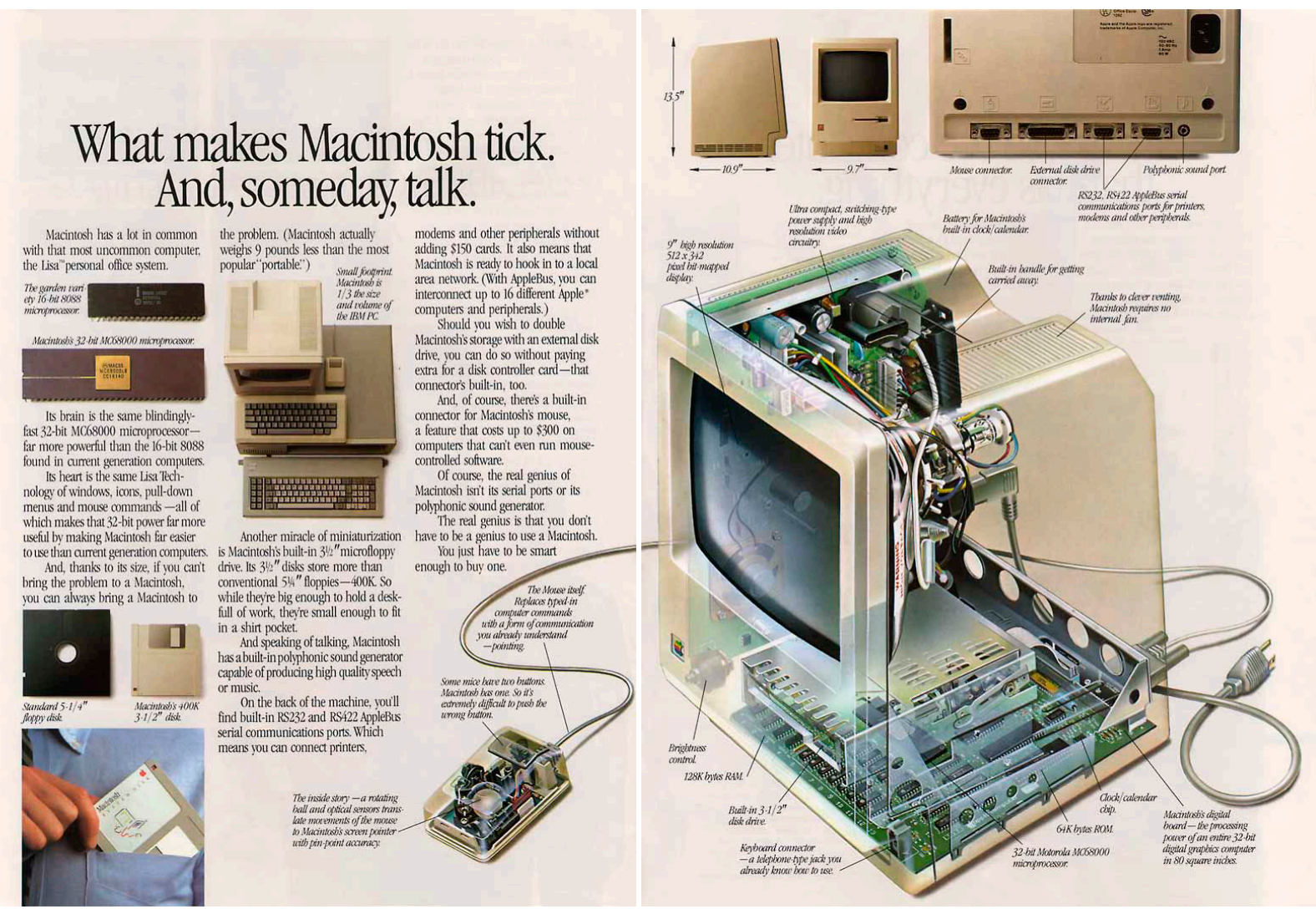

Figura 11-12: Páginas do folder de divulgação do Apple Lisa, lançado em 1984

(Fonte: <http://www.macmothership.com/gallery/gallery3.html> Acesso em: 9 Fev. 2014)

Seguindo este raciocínio, a primeira metade da década de 1980 foi caracterizada pela consolidação do computador pessoal como um bem de consumo de massa, culminando em sua venda em prateleiras de supermercados e lojas especializadas (FORESTER, 1987). Assim, de forma simplificada, pode-se dizer que a década que seguiu sua disseminação (1984-1994) foi marcada pela intensa competitividade entre as empresas, investimento massivo em seu barateamento, e desenvolvimento de softwares para os tornarem mais úteis e fáceis de serem utilizados por este mercado emergente (WINSTON, 1998).

A facilidade de uso foi alcançada com o desenvolvimento de interfaces gráficas mais "amigáveis" em substituição às linhas de comando. Os conceitos que formataram as GUls (Graphical User Interfaces) foram, em grande parte, elaborados pelos pesquisadores da Xerox PARC (Palo Alto Research Center), durante a década de 1970. Eles tinham a tarefa de criar o escritório do futuro partindo do pressuposto que os computadores não serviam apenas para o processamento de dados e números mas, acima de tudo, para a comunicação (SAFFER, 2010, p.13).

Apesar de a Xerox nunca ter investido no marketing dos conceitos que foram ali desenvolvidos, quando voltou o foco para seu interesse inicial (máquinas fotocopiadoras), suas idéias e seus pesquisadores se espalharam e influenciaram, decisivamente, o direcionamento das interfaces, tanto gráficas quanto físicas, dos 
computadores pessoais (BRIGGS; BURKE, 2004). Steve Jobs e os demais engenheiros da Apple tiveram contato com este conteúdo em uma demonstração no final da década de 1970. De tal modo que, por mais que já estivessem trabalhando com suas próprias interfaces gráficas, foram diretamente influenciados pelo que viram e se convenceram ainda mais do caminho que estavam seguindo (Figura 13). Assim, como aponta Saffer (2010, p.13):

A Xerox PARC permanece lendária. Suas contribuições para o campo, muitas das quais estão contidas em seus produtos de linha Xerox Alto e Xerox Star, são tudo desde janelas e ícones e a metáfora do desktop até a edição de texto WYSIWYG [o que você vê é o que você tem]. Os funcionários incluíam Alan Kay, que concebeu o primeiro computador laptop, o Dynabook, em 1968; Larry Tesler e Tim Mott, que conceberam a metáfora do desktop e interações não padronizadas tal como cortar-e-colar; e Robert Metcalfe, que inventou as redes Ethernet em 1973.32

Paralelamente às questões de usabilidade, outro desafio enfrentado pelos produtores de computadores para conquistar o mercado doméstico foi sua utilidade neste novo contexto. Segundo Winston (1998), o computador pessoal não foi um fenômeno com instantânea adoção pelas indústrias e pelos consumidores. Ao contrário, a idéia inicial de um computador doméstico não foi recebida com entusiasmo, de forma que a utilidade das máquinas que foram produzidas era extremamente limitada e a assistência técnica era restrita em decorrência, entre outros fatores, da sua rápida obsolescência e do fechamento das empresas que não sobreviviam à agressividade deste mercado emergente. Apesar da publicidade exagerada, no início, o computador era utilizado apenas para jogos ou para praticar programação (WINSTON, 1998).

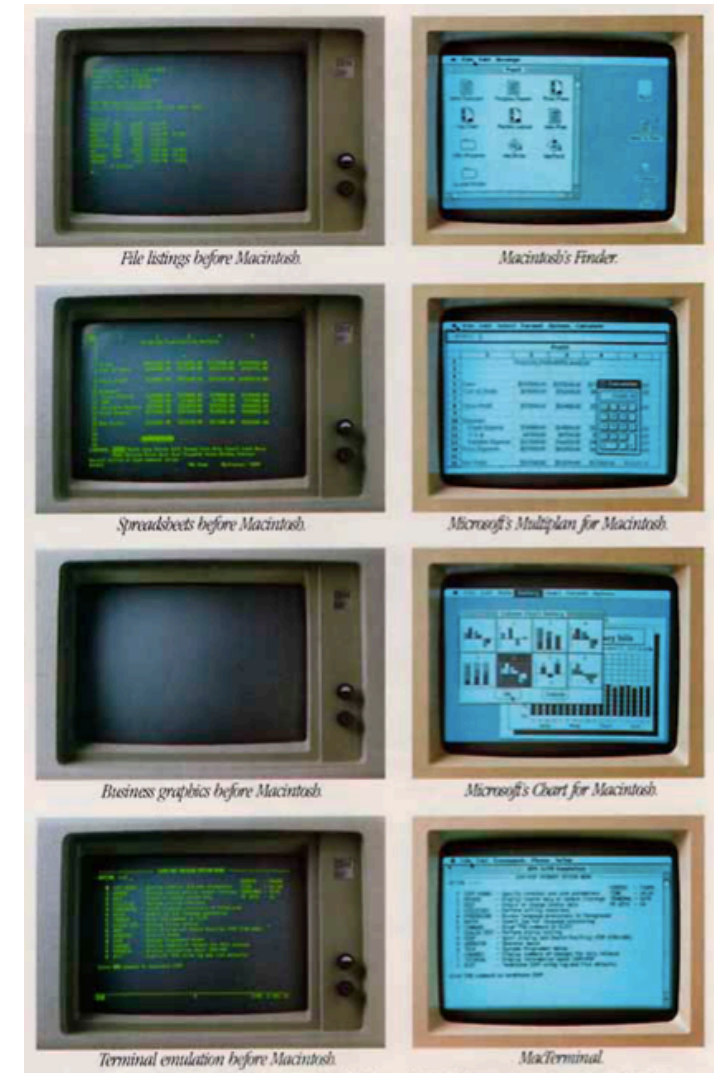

Figura 13: Comparação entre interfaces textuais e as interfaces gráficas - GUI - do Apple Lisa (Fonte: <http://www.macmothership.com/gallery/gallery3.html> Acesso em: 9 Fev. 2014)

\footnotetext{
32 Do original em inglês: Xerox PARC remains legendary. Its contributions to the field, many of which are contained in its signature products the Xerox Alto and Xerox Star, are everything from windowing and icons and the desktop metaphor to WYSIWYG text editing. Employees included Alan Kay, who conceived the first laptop computer, the Dynabook, in 1968; Larry Tesler and Tim Mott, who conceived the desktop metaphor and such nonstandard interactions such as cut-and-paste; and Robert Metcalfe, who invented Ethernet networking in 1973 (SAFFER, 2010, p.13).
} 
A década que se seguiu (1994-2004) foi marcada pela incorporação de dois aspectos que contribuíram, significativamente, em dotar o computador pessoal de usos domésticos relevantes: a conexão em rede (internet) e a multimídia interativa.

Embora a Internet tivesse começado na mente dos cientistas da computação no início da década de 1960, uma rede de comunicação por computadores tivesse sido formada em 1969, e comunidades dispersas de computação reunindo cientistas e hackers tivessem brotado desde o final da década de 1970, para a maioria das pessoas, para os empresários e para a sociedade em geral, foi em 1995 que ela nasceu (CASTELLS, 2003, p.19).

Com sua popularização, a Internet transformou a posição social do computador, de máquina utilizada para otimização e organização de tarefas passou também a mediar a conversação entre as pessoas. Em acréscimo aos meios tradicionais de comunicação, foram introduzidos novos formatos, tais como e-mails (mensagens de texto instantâneas) e conversas on-line coletivas. A estas configurações seguiram-se extensas discussões sobre o aparecimento de novos padrões de interação social, que oscilavam entre ponderações relacionadas a um comunitarismo renovado e à alienação social (CASTELLS, 2003).

A conexão em rede de computadores deu origem também à noção bastante debatida de uma nova camada espacial, denominada ciberespaço, formada pelo domínio relacional entre os nós que compõe a Internet, de forma que,

Cada dia, milhares de novos nós ou "sites" são acrescentados à Internet e outras redes afiliadas, e com cada novo nó o domínio total do ciberespaço aumenta. 0 que cresce neste caso não é o volume num sentido estritamente geométrico - no entanto é uma espécie de volume. No ciberespaço, cada site está conectado a dezenas, ou mesmo milhares de outros sites através de links definidos por software. Essas conexões digitais vinculam sites uns aos outros numa teia labiríntica que se ramifica em muitas "direções" ao mesmo tempo (WERTHEIM, 2001, p.163).

Simultaneamente à formação de uma rede global de computadores, a digitalização de vários tipos de informação, tais como som, imagem, textos, animações e vídeos, permitiu a conversão dos diversos meios de comunicação para o formato digital. Isso, somado à possibilidade de acesso randômico e à recombinação culminou na multimídia interativa, também denominada hipermídia ou mídia interativa híbrida (COTTON; OLIVER, 1992).

Esta intenção de comunicação não-linear e multimodal de idéias, no formato de "[...] uma mídia única que combinou todas as outras mídias de forma que as pessoas 
podiam controlá-la usando linguagem natura e gestos"33 (COTTON; OLIVER, 1992, p.11), acompanhou o desenvolvimento do computador desde meados da década de 1940. Contudo, foram os computadores pessoais da década de 1990 , enquanto aparato único e multifuncional, que tornaram acessíveis a produção e a manipulação dessas informações. Assim sendo, a multimídia tornou-se o novo formato utilizado tanto para produzir e comunicar idéias quanto para o entretenimento, e a Internet o meio (protocolo) para trocar estas informações.

A este novo padrão de comunicação, Packer e Jordan (2002, p.xxv) atribuem cinco características específicas:

Integração: a combinação das formas artísticas e da tecnologia numa forma híbrida de expressão. Interatividade: a capacidade do usuário de manipular e afetar diretamente a experiência da mídia e de se comunicar com outros através dela. Hipermídia: a ligação de elementos separados da mídia uns com os outros para criar uma trilha de associação pessoal. Imersão: a experiência de ingressar na simulação de uma ambiente tridimensional. Narratividade: estratégias estéticas e formais que derivam dos conceitos acima e que resultam em formas não lineares de história de apresentação da mídia. ${ }^{34}$

O período entre 2004-2014, além de intensificar os desenvolvimentos prévios, apresenta outras especificidades. Se, até então, o desenvolvimento da tecnologia digital enfatizava a concentração das atividades em uma única máquina que daria acesso ao mundo virtual, esta terceira década foi marcada pela tendência em espalhar o poder computacional nos domínios mais triviais do cotidiano, como aponta Greenfield (2006, p.18-19):

O que estamos contemplando aqui é a extensão das capacidades de sentir, processar e conectar em rede informações para classes inteiras de coisas, nunca antes imaginadas como 'tecnologia'. Pelo menos, não temos pensado nelas desta forma durante muito, muito tempo: falo de artefatos tais como roupas, mobiliário, paredes e corredores. ${ }^{35}$

\footnotetext{
33 Do original em inglês: [...] a singular medium that combined all the other media in such a way that people could control it using natural language and gesture (COTTON; OLIVER, 1992, p.11).

34 Do original em inglês: Integration: the combining of artistic forms and technology into a hybrid form of expression. Interactivity: the ability of the user to manipulate and affect her expeprience of media directly, and to communicate with others through media. Hypermedia: the linking of separate media elements to one another to create a trail of personal association. Immersion: the experience of entering into the simulation or suggestion of a three-dimensional environment. Narrativity: aesthetic and formal strategies that derive from the above concepts, which result in nonlinear story forms and media presentation (PACKER; JORDAN, 2002, p.xxv).

35 Do original em inglês: What we're contemplating here is the extension of information sensing, processing, and -networking capabilities to entire classes of things we've never before thought of as 'technology'. At least, we haven't thought of them that way in a long, long time: I'm talking about artifacts as clothing, furniture, walls and doorways (GREENFIELD, 2006, p.18-19).
} 
No início do século XXI, apesar dos microprocessadores já serem encontrados em um grande número de objetos técnicos, tais como câmeras fotográficas e telefones, eles começaram a ser inseridos, também, em objetos tradicionais do cotidiano. Além disso, esse espectro crescente de "coisas digitais" passou também a incorporar a possibilidade de compartilhar entre si a informação processada. Assim, especialmente com a viabilização técnica, a implementação de idéias relacionadas a outras maneiras de incorporação da tecnologia digital no cotidiano, tais como as delineadas por Weiser (1990) e Ishii (1997), foi gradativamente viabilizada e problematizada.

Weiser é citado por diversos autores, tais como Moggridge (2007), Sharp (2007) McCullough (2004) Greenfield (2006) e Poslad (2009), entre outros, como o criador da expressão Computação Ubíqua. No início dos anos 1990, no texto The computer for the 21st century, ele menciona sua busca, juntamente com os demais pesquisadores da Xerox PARC, em "[...] conceber uma nova forma de pensar sobre os computadores no mundo, que leve em conta o ambiente natural humano e permita que os próprios computadores desapareçam no pano de fundo" ${ }^{\prime 36}$ (WEISER, 1991, n.p.).

Para a manifestação da computação ubíqua seria necessário trazer a capacidade de computação de dados para o mundo real ao invés de mantê-la fechada nas caixas que são, em última instância, os computadores pessoais. Em termos de infraestrutura necessária, Weiser (1991) refere-se a centenas de pequenos computadores por cômodo, sendo que o poder da ubiqüidade emergiria não de objetos específicos e, sim, da interação e troca entre eles. O autor, exemplifica esses objetos, a partir de idéias desenvolvidas com seus colegas que compreendem um conjunto de superfícies display em diferentes escalas: na escala da polegada (inchscale), na escala do pé (footscale) e na escala da jarda (yardscale) $)^{37}$.

Para ilustrar a idéia de computação ubíqua ele cria, no artigo, um cenário cotidiano e relata um dia na vida de uma mulher fictícia chamada 'Sal'. Entre outros objetos, descreve o despertador que, ao tocar, verifica se a mulher quer café, caso ela assinale que o quer, o despertador conecta-se com a cafeteira na cozinha que providencia seu preparo. Além disso, Weiser (1991) apresenta canetas com a capacidade de capturar imagens. Com elas, pedaços de notícias de jornais ou trechos de livros e revistas podem ser salvos em arquivos para serem, posteriormente, compartilhados. Vários outros exemplos são descritos, sendo que todos os objetos são baseados no emprego de tecnologias relativamente baratas, sempre conectadas em rede, dotadas de software específicos para essas aplicações ubíquas.

\footnotetext{
36 Do original em inglês: to conceive a new way of thinking about computers in the world, one that takes into account the natural human environment andallows the computers themselves to vanish into the background (WEISER, 1991:sp).

37 Inch, foot e yard são unidades do sistema americano de medidas e correspondem, respectivamente, a 2,54 cm (inch) , $30.48 \mathrm{~cm}$ (foot) e 91,44 cm (yard).
} 
A crítica ao computador pessoal também está presente no trabalho do Tangible Media Group, do MIT. Ishii e Ulmer (1997, p.1) associam os projetos desenvolvidos pelo grupo com o termo Tangible User Interfaces (TUI) ou interfaces tangíveis (Figuras 14-17). Partem da constatação de que

“[...] as interações entre as pessoas e o ciberespaço estão amplamente confinadas a tradicionais caixas baseadas em interfaces gráficas - instaladas em computadores de mesa, laptops ou palmtops. As interações com estas GUI estão separadas do ambiente físico no qual vivemos e interagimos" 38
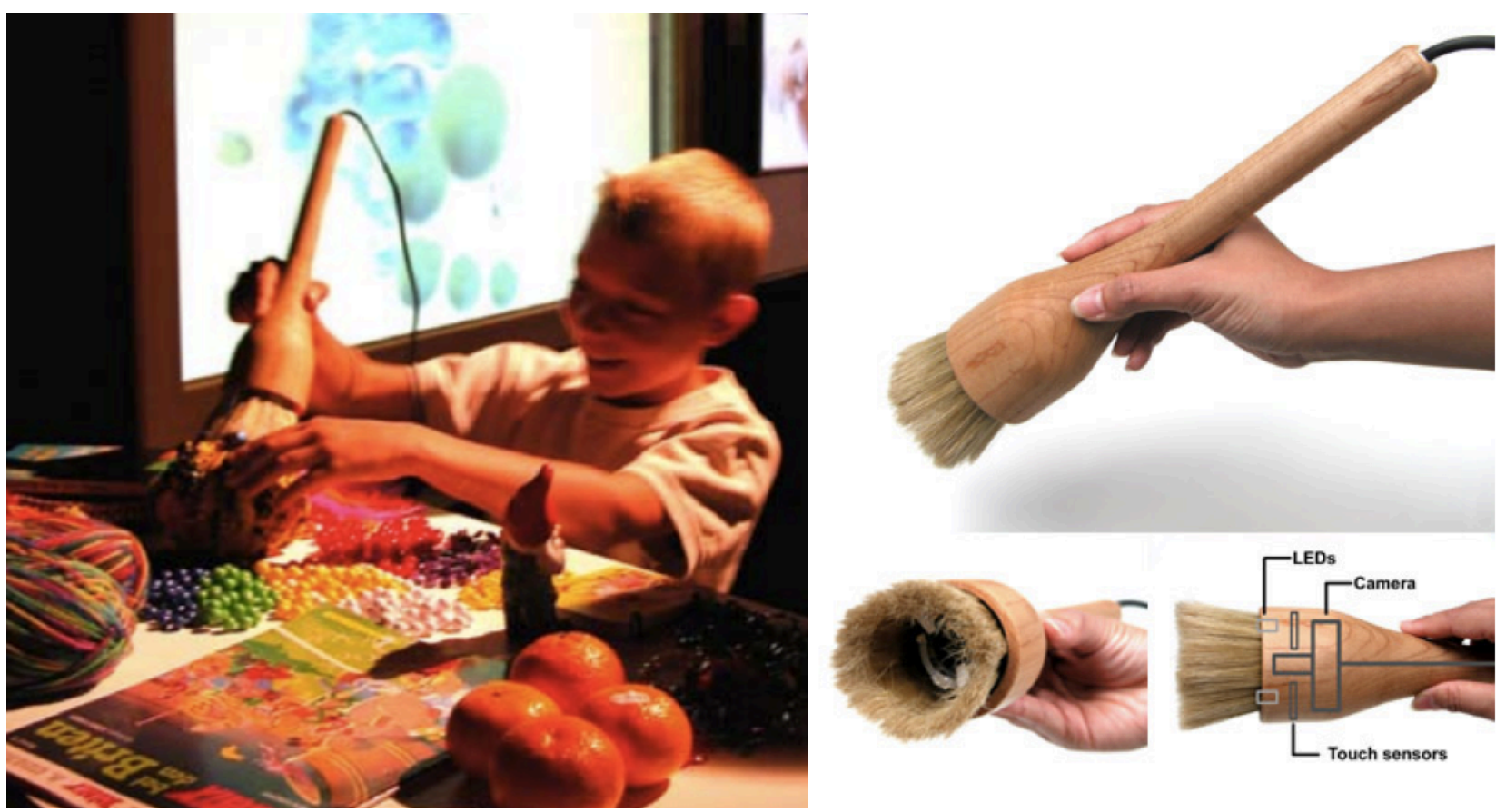

Figura 14-17: Projeto I/O Brush, do Tangible Media Group - MIT (2004). Interação com bits por meio de interfaces físicas, inspiradas em objetos cotidianos (Fonte: <http://web.media.mit.edu/ kimiko/iobrush/> Acesso em 9 Fev. 2014)

Por mais que o mouse e o teclado possibilitem o controle das informações, por meio da manipulação dos elementos das interfaces gráficas, de forma maleável e flexível, suas características genéricas os impedem de estabelecer uma relação significativa com as representações gráficas dos bits na tela. A idéia básica das interfaces tangíveis é dar uma forma física, uma representação tangível à informação e computação "[...] tirando vantagem dos múltiplos sentidos e da multimodalidade das interações humanas com o mundo real" ${ }^{39}$ (ISHII; ULMER, 1997, p.8). Deste modo, as interfaces tangíveis, por meio de objetos interativos e mídia ambiente, prioriza a experiência multisensorial da informação digital.

\footnotetext{
38 Do original em inglês: The interactions between people and cyberspace are now largely confined to traditional GUI (Graphical User Interface)-based boxes sitting on desktops or laptops. The interactions with these GUIs are separated from the ordinary physical environment within we live and interact (ISHII; ULMER, 1997, p.1).

39 Do original em inglês: Taking advantage of multiple senses and the multimodality of human interactions with the real world. We believe the use of graspable objects and ambient media will lead us to a much richer multi-sensory experience of digital information (ISHII; ULMER, 1997, p.8).
} 
Por um lado, o fato técnico que caracteriza esta última década consiste no aumento da potência dos processadores, na diminuição significativa do tamanho e custo dos componentes digitais, e na ampliação da conectividade por meio de redes sem fio, com grande capacidade de transmissão de dados. Por outro, uma vez que a tecnologia digital e a internet encontraram seu espaço no cotidiano e foram incorporadas ao imaginário das pessoas, passou-se a questionar o formato limitado do computador pessoal enquanto ponto de acesso à informação. Isso, somado ao interesse do mercado em aproveitar os ganhos econômicos trazidos por inovações, faz com que aumente o interesse na experimentação com as possibilidades oferecidas pela tecnologia digital, em especial, aquelas relacionadas à disponibilidade da informação em todas as coisas, lugares e momentos.

Em relação a este contexto tecnológico, para explorar com profundidade as possibilidades da tecnologia digital, é necessário ir além do estereótipo mouse-telateclado, de forma a enfatizar que a computação (e não o computador) é o que caracteriza sua essência. Computação ubíqua e interfaces tangíveis, dentre outros, são conceitos que esboçam diferentes perspectivas de uma vertente do desenvolvimento da tecnologia digital que repensa seus modos de manifestação, por meio de sua disseminação pelos objetos e ambientes. Por mais que "[...] diferenciações são quase sem sentido da perspectiva das pessoas expostas à computação que todas essas teorias parecem descrever" ${ }^{\prime 0}$ (GREENFIELD, 2006, p. 15), tratam-se de conceitos paralelos que compartilham características básicas, mas diferem-se em suas ênfases e aplicações.

Neste sentido, a arquitetura interativa pode ser entendida como um desses movimentos que busca integrar a computação ao espaço físico e, assim como os outros, ao mesmo tempo que compartilha algumas de suas características, possui suas próprias peculiaridades. Esta pluralidade de perspectivas pode ser considerada uma das diversas artimanhas da tecnologia digital e para entender os diferentes discursos em suas semelhanças e diferenças é importante, primeiramente, um entendimento básico dos embasamentos técnicos que dão suporte a eles.

\subsubsection{Características básicas da tecnologia digital}

O modelo associado ao computador pessoal tem este como uma máquina genérica centralizadora de ações, cuja funcionalidade é determinada pelos softwares e hardware periféricos, comprados prontos para serem instalados e utilizados. 0 conhecimento necessário a não especialistas vai pouco além da manipulação destes.

40 Do original em inglês: Distinctions are close to meaningless from the perspective of people exposed to the computing these theories all seem to describe (Greenfield, 2006, p. 15). 
Mesmo para programadores que desenvolvem softwares altamente elaborados, qualquer experiência com a criação de hardware e circuitos eletrônicos é dispensável.

No entanto, para compreender os discursos relacionados a alternativas de incorporação da tecnologia digital nos objetos e no espaço físico, os computadores precisam ser entendidos sob outra perspectiva. Nesta, de forma simplificada, seu núcleo básico é formado por três componentes: sensores, núcleos processadores e atuadores, como Figura 18. Os sensores são responsáveis pela aquisição de informação para o sistema (input); os processadores comparam e processam essas informações, de acordo com as seqüências de instruções implementadas em sua memória; e os atuadores devolvem o resultado da computação para o ambiente (output).

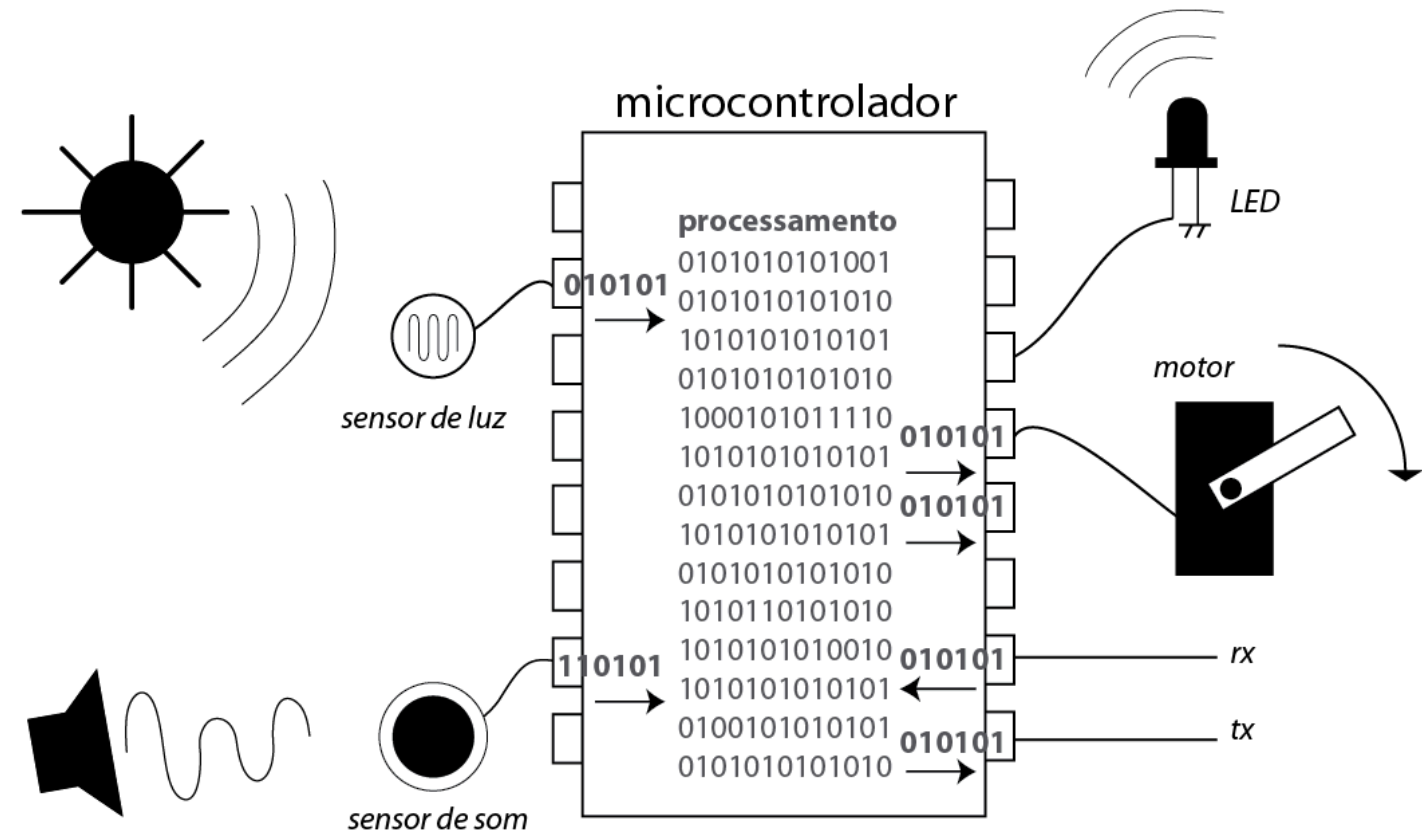

Figura 18: Sensores de luz e de som conectados a um microcontrolador conversor analógico-digital. As informações recebidas são processadas e o resultado deste determina o controle de um LED e de um motor. Além disso, pulsos ritmizados enviam (tx) e recebem (rx) informações (Fonte: Gabriela Carneiro)

Os sensores e os atuadores, também denominados transdutores, são os elementos responsáveis pela conexão entre mundo físico e sistema digital ao transformarem diferentes tipos de energia (calor, luz, pressão, etc.) em pequenos pulsos elétricos apropriados para serem interpretados pelo computador (O'SULLIVAN; IGOE, 2004). Quando o que fornecem é uma alternância de estados (ligado-desligado, zero-um) são considerados digitais; caso induzam uma variação gradativa da voltagem elétrica são classificados como analógicos.

Um botão, por exemplo, é um componente que, quando acionado, fecha um circuito elétrico e deixa a energia passar, sendo assim, é um sensor digital. Um sensor fotoelétrico é composto por materiais semicondutores que variam a resistividade, de acordo com a quantidade de luz a qual é exposto, e consequentemente a quantidade 
de energia que deixa passar, o que faz dele um sensor analógico. Um motor é um atuador, que pode ser controlado tanto como digital quanto analógico. Quando o controle liga ou desliga o motor, se quando ligado a sua velocidade é constante, ele é digital, caso o controle varie sua velocidade, é considerado analógico. A manipulação destes pequenos pulsos elétricos, também denominados energia discreta, é a base da tecnologia digital, o que torna os sensores e atuadores dois de seus principais componentes.

Os núcleos processadores são compostos por circuitos lógicos responsáveis, dentre outros processos: por receber os valores dos sensores; interpretá-los, conforme instruções; tomar decisões, de acordo com as mudanças identificadas, e ativar atuadores. As possibilidades lógicas entre input e output é o grande diferencial da tecnologia digital, e a programação (softwares) é o que determina as sequências de ações a serem executadas.

Um circuito formado por um interruptor e uma lâmpada não precisa de computação. Neste caso, a relação é simples e direta: uma vez que o interruptor é acionado, ele fecha um circuito que permite a passagem de energia pela lâmpada fazendo, com que ela acenda. Com um computador digital, a relação entre o interruptor e a lâmpada pode ser muito mais complexa. "Por exemplo, você pode fazer a luz acender de acordo com o número de vezes que o botão foi pressionado, por quanto tempo foi pressionado, ou se ele foi pressionado junto com outros botões em outros cômodos ou em outros continentes" ${ }^{\prime 1}$ (O'Sullivan; Igoe, 2004, p. xviii). Neste sentido, a presença de sensores e atuadores e um núcleo processador de informação digital já é suficiente para configurar um objeto como um computador.

Além de receber informações de um sensor ou controlar um atuador, a capacidade de emitir e receber pulsos elétricos de um computador pode ser coordenada de forma a possibilitar a troca de mensagens. Para que isso aconteça, de acordo com Igoe (2007, p.19), uma conexão compartilhada entre dois computadores deve ser estabelecida e os pulsos elétricos precisam ser temporizados (ritmados) em padrões específicos, denominados protocolos de comunicação, que definem "[...] o ritmo no qual as mensagens são trocadas, o arranjo dos dados nas mensagens, e a gramática da troca. $^{\text {"42 }}$

Dados nada mais são do que uma sequência de pulsos que podem ser tanto elétricos, quanto convertidos para outros tipos de energia, conforme o meio utilizado para sua

\footnotetext{
41 Do original em inglês: For example, you can make the light's turning on dependent on the number of times the button was pressed, for how long it was pressed, or whether it was pressed in conjunction with other buttons in other rooms or on other continents (O'SULLIVAN; IGOE, 2004, p. xviii).

42 Do original em inglês: A communications protocol usually defines the rate at which messages are exchanged, the arrangement of data in the messages, and the grammar of the exchange (IGOE, 2007, p.19).
} 
transmissão. Por exemplo, para transmitir dados por fibra ótica, é necessário sua conversão em pulsos luminosos, da mesma maneira a utilização de transceivers (rádios emissores e receptores) permite a troca de informações via rádio frequências. "O significado dos pulsos de dados é independente do meio que os carregam. Você pode utilizar a mesma sequência de pulsos se enviá-los por fios, cabos de fibra óptica, ou rádios" $^{43}$ (IGOE, 2007, p.19).

Além de possibilitar a troca direta de informações, a sobreposição de diversos tipos e níveis de protocolos permite a comunicação entre múltiplos computadores interconectados, tal como acontece com a internet. Segundo Galloway (2007), sua estrutura pode ser explicada a partir de quatro camadas, cada uma com sua função. A primeira camada é responsável por encapsular o conteúdo, ou seja, as informações que precisam ser transferidas, sejam elas referentes a um comando, texto, imagem, áudio ou vídeo. Os protocolos dessa camada dividem as informações em pequenos pacotes para serem transportados de maneira eficiente ao longo da rede e reagrupadas uma vez que o destino é alcançado.

Na segunda camada, um protocolo distinto é responsável pelo estabelecimento e manutenção da conexão entre dois computadores e por garantir que a informação chegue ao seu destino. Na terceira camada, um outro protocolo possui a tarefa de movimentar a informação pelas vias de transmissão menos congestionadas, mesmo que não sejam as mais curtas, de forma que o importante é garantir que a informação chegue ao destino correto com a máxima eficiência. Por último, a variação do meio físico pelo qual a informação é transmitida também exige protocolos específicos, de acordo com as propriedades do material utilizado para a propagação dos pulsos. A função dos protocolos, desta última camada, é garantir que a alternância entre meios não modifique a informação que está sendo transmitida (GALLOWAY, 2007).

A internet é um dos conjuntos de protocolos utilizados para conectar computadores em rede, mas não é o único. Redes privadas, por exemplo, podem ser criadas, utilizando sua própria estrutura e padrões para a troca de informações. A disponibilidade irrestrita da internet e o crescente número de aplicações acopladas a ela contribuiram para sua popularidade e produziram um efeito progressivo que estimula cada vez mais a adição de novas redes e conteúdos. Isso, somado à sua capacidade de abranger uma ampla gama de outros protocolos, a fez "[...] evoluir lentamente como uma rede universal de redes, que conecta quase todas as redes de

\footnotetext{
43 Do original em inglês: The meaning of data pulses is independent of the medium that's carrying them. You can use the same sequence of pulses whether you're sending them across wires, fiber optic cables, or radios (IGOE, 2007, p.19).
} 
dados do mundo com um alcance espalhado por toda a terra."44 (TALUKDER; YAVAGAL, 2007, p.34).

Assim sendo, em seu nível mais fundamental (baixo), a tecnologia digital pode ser resumida à conversão de diferentes tipos de energia em pulsos elétricos, somada ao armazenamento, à manipulação lógica destes e (quando necessário) sua transmissão por diferentes meios físicos. Ao longo das décadas, foram construídas diversas camadas acima deste zero ou um, que vêm transformando a forma como a tecnologia é pensada e utilizada, tal como linguagens de programação, protocolos de comunicação e interfaces físicas. A partir deste entendimento, fica claro que computadores não precisam, necessariamente, assumir a forma do computador multimídia tradicional. Pelo contrário, segundo O’Sullivan e Igoe (2004, p.xvii), “[...] os computadores devem tomar qualquer forma física que se adéque às nossas necessidades de computação." 45

Todos estes discursos, que permeiam o contexto tecnológico, devem ser encarados com ressalva. Araya (1995), por exemplo, aponta algumas preocupações tão importantes quanto a projeção de possibilidades tecnológicas, em cenários futuros, e critica a abordagem de Weiser (1991) ao apontar que a computação ubíqua se justifica mais pela própria tecnologia do que pelas necessidades e atividades dos usuários.

Levando em consideração a prioridade dada à tecnologia acima das necessidades, a sugerida penetração massiva na vida cotidiana por um tipo particular de tecnologia, a tentativa de imergir tecnologia no pano de fundo como forma de ultrapassar a resistência a ela, e o fato de que esses desenvolvimentos não são questionados e sim vistos como absolutos, caracterizamos o pensamento que permeia a computação ubíqua como uma forma emergente de absolutismo tecnológico46 (ARAYA, 1995, p.236).

Para o autor, o que falta no discurso tecnológico é uma preocupação sobre os efeitos mais profundos que essa tecnologia teria no cotidiano. Aspectos relacionados com as transformações da vida, na qual a computação ubíqua é inserida e como essas transformações afetam a forma como o mundo se mostra para as pessoas, as pessoas para o mundo, e como dialogam entre si, devem ser cuidadosamente tratados. Desse modo, os fatores que conduzem uma proposta tecnológica, ou seja, como o

\footnotetext{
44 Do original em inglês: Internet slowly evolved as the universal networks of networks, which connects almost every data networks of the world with a reach spread over the whole earth (TALUKDER; YAVAGAL, 2007, p.34).

45 Do original em inglês: Computers should take whatever physical form suits our needs for computing (O'SULLIVAN; IGOE, 2004, p. xvii).

46 Do original em inglês: Taking into account the primacy given to technology over needs, the proposed massive penetration of everyday life by a particular kind of technology, the attempt to immerse technology into the background partially as a way to bypass resistance to technology, and the fact that these developments are not questioned but regarded as absolute, we characterize the thinking underlying Ubiquitous Computing as an emerging form of technological absolutism (ARAYA, 1995, p. 236).
} 
pensamento por trás dela a justifica, devem ter a mesma importância das soluções e possibilidades alcançadas.

Por outro lado, por mais que o cotidiano não precise, necessariamente, de computação e que a disponibilidade de muita informação possa apresentar tantos problemas quanto sua escassez, o que Greenfield (2006) descreve é uma realidade na qual tarefas habituais tendem a ser cada vez mais mediadas por ela. Entender a natureza das questões colocadas pelo discurso tecnológico, assim como a forma que este vem se realizando, a partir da segunda metade do século $X X$, é imprescindível para criar novos espaços nos quais possam ocorrer o direcionamento de sua realização, ou, até mesmo, sua superação.

Do mesmo modo, para completar a trama com a qual a arquitetura interativa dialoga diretamente é importante delinear alguns aspectos do contexto socioespacial. Este, entendido como a conjuntura física na qual as relações sociais mediadas pela computação acontecem, e onde os antagonismos do paradigma técnico se manifestam intensamente. Além disso, é nele e para ele que a arquitetura interativa deve ser pensada e realizada.

\subsection{Contexto socioespacial}

Segundo Brown e Duguid (2001, p.1-2), a ênfase no digital e na informação leva a um esquecimento ingênuo dos recursos necessários para produzi-la e para dar significado a ela. Isso é fruto do que os autores denominam tunnel vision, uma abordagem da realidade que "[...] elimina o campo de visão periférica, fazendo com que as pessoas que a tenham vejam onde querem chegar, porém muito pouco além disso". Nessa perspectiva, fundamentada no racionalismo instrumental/subjetivo, a informação é utilizada, intensamente, para alcançar com rapidez e eficiência o que se quer. E, para isso, é descartado tudo o que não pode ser codificado e explicado de forma sistemática, por exemplo, o contexto, o cenário de fundo, a história, o conhecimento compartilhado e os recursos sociais.

No entanto, como observam os autores, “[...] este conteúdo marginal não é tão irrelevante quanto possa parecer. Ele fornece equilíbrio e perspectiva valiosos. Ele detém alternativas, oferece uma visão mais ampla e indica opções; ajuda a esclarecer os objetivos e suportar o significado." Em outras palavras, o que está além da informação é, justamente, o que confere sentido à ela.

No momento em que, com o telégrafo, a informação passou a chegar ao seu destino com uma velocidade bem além daquela alcançada pelo homem e seus meios tradicionais de transporte, costuma-se dizer que ela se "[...] separou do seu meio" . 
Com isso, além de a informação adquirir sua própria velocidade e criar seu próprio espaço, aos poucos também adquiriu sua própria vida, ou seja, passou a se reproduzir sem a intervenção humana (BROWN; DUGUID, 2001, p. 15). Esse mito da separação que acompanha sua origem acaba ofuscando, na maioria das vezes, toda a infra estrutura material e social que dá suporte ao seu desenvolvimento.

O mito ofusca significativamente a sociedade quanto ao caráter das forças por trás dessas mudanças. Em particular, o mito tende a travar uma guerra contínua contra os aspectos da sociedade que desempenham um papel crítico em moldar não somente a sociedade, mas a informação em si, tornando a informação útil e fornecendo-lhe valor e significado. (BROWN; DUGUID, 2001, p. 28)

Não há dúvidas de que a tecnologia digital é responsável por contribuições críticas e sem precedentes para as mudanças experimentadas pela sociedade, porém. é importante compreender que essas mudanças são resultado de um complexo muito maior de causas, e não apenas da informação em si. Ao esboçar o que seria essa vida social da informação, Brown e Duguid (2001, p.19-27), sem diminuir sua importância, destaca a tendência equivocada dos futurólogos em elaborar previsões que identificam pontos de mudanças e os extrapolam, linearmente, sem notar outras forças que possam estar se agrupando. Ao adotar uma perspectiva distinta, suas análises indicam uma outra tendência, na qual a "[...] sociedade parece capaz de mover-se em quase todas as direções. Assim, mais do que celebrar a separação, é importante entender as diferentes maneiras nas quais a informação e a sociedade se entrelaçam. Afinal,

Os objetivos da informação são os objetivos dos seres humanos. A lógica da informação, definitivamente deve ser a lógica da humanidade. Para toda a independência e extensão das informações, são as pessoas, em suas comunidades, organizações e instituições, que de fato decidem o que tudo isso representa e a razão de sua importância (BROWN; DUGUID, 2001, p. 15).

Dada a complexidade das questões sociais que se entrelaçam com a produção e o consumo da informação e das tecnologias que dão suporte a ela, análises implicam sempre a redução desse contexto. Esgotar as possibilidades de leitura do tema é praticamente impossível. Para o contexto deste estudo, mais do que aprofundar diferentes leituras e entendimentos, é importante indicar caminhos de interpretação e entendimento passiveis de serem estendidos a outras questões. Para isso, parte-se do princípio segundo o qual qualquer análise que tenha como objeto a relação entre tecnologia e sociedade deve buscar, quando possível, expandir o que a informação e seus princípios normalmente comprimem. 
Para ilustrar possíveis modos de descompressão, em um primeiro momento, discursos associados ao ciberespaço e à cidade inteligente são analisados de forma a ilustrar como a tecnologia se entrelaça com expectativas fundamentalmente humanas. Em seguida, são delineadas alguns dos diferentes aspectos que envolvem a contextualização da tecnologia digital. Para finalizar, são esboçadas questões controversas que envolvem a progressiva disseminação da tecnologia, com o objetivo de ilustrar sua natureza paradoxal.

Sobretudo, esse tópico oferece um caminho de leitura para o entendimento da complexidade das questões relacionadas à inserção da tecnologia, nos diferentes contextos sociais. É a partir destas condições mistas e aparentemente contraditórias, que a arquitetura interativa deve ser compreendida e elaborada. Não se trata de uma nave espacial que chega e se impõe enquanto verdade necessária ou solução para todos os problemas. Ao mesmo tempo, a tecnologia e toda sua infraestrutura não deve ser entendida como um problema alheio à arquitetura, já que é, a cada dia mais, parte indissociável do tecido urbano e social do qual faz parte. Assim sendo, ao abordar a relação entre tecnologia e sociedade, o objetivo é ampliar as camadas de entendimento deste ponto de contato entre o que é possível fazer em termos tecnológicos e as questões humanas e sociais que devem ser levadas em consideração.

\subsubsection{Além do ciberespaço e das cidades inteligentes}

Murray (2001, p.78), ao abordar o futuro da narrativa eletrônica, elenca quatro propriedades do meio digital, que podem ser compreendidas como decorrentes dos fundamentos da tecnologia abordados no item anterior. "Ambientes digitais são procedimentais, participativos, espaciais e enciclopédicos", de forma que, juntas, essas características conferem ao meio digital sua especificidade interativa e imersiva.

A propriedade procedimental está ligada à possibilidade do computador executar uma série de regras, isso faz com que, além de transmitir informações, incorpore comportamentos complexos e não-lineares. A participação relaciona-se com sua capacidade de reagir às informações que são neles introduzidos, o que possibilita a indução de comportamentos específicos por parte do usuário. Sua qualidade espacial decorre da possibilidade de navegação dentre dados, páginas, imagens, simulações, etc., na qual cada estímulo (input) compõe um caminho dentro de uma estrutura maior. A característica enciclopédica relaciona-se à sua capacidade de armazenamento e recuperação de informações (MURRAY, 2001).

São essas propriedades, tanto separadas quanto coletivamente, que fazem do meio digital "[...] um poderoso veículo para criação literária” (MURRAY, 2001, p. 78). Dessa forma, a tecnologia digital, mais do que um meio de comunicação, o qual congrega 
todos outros, é um meio com seu próprio conjunto de características específicas disponíveis para a atividade criativa. Para esta pesquisa, a definição apresentada pela autora é retomada com o intuito de oferecer uma descrição mais precisa da camada informacional, acrescida pela tecnologia digital à realidade maior da qual fazem parte homem e ambiente. Por possuir uma estrutura específica, este ambiente com geografia própria, que permite visitar lugares, recebe a designação de ciberespaço.

As características propostas por Murray (2001), abrem caminho para o entendimento do ciberespaço como um conceito que não se resume à conexão em rede de computadores e à sua função comunicativa que conecta lugares geograficamente distantes. Pelo contrário, o ciberespaço não pressupõe necessariamente a conexão de vários computadores, de forma que pode ser identificado em uma única máquina. Da mesma forma, não pressupõe a existência de gráficos, mapas ou imagens de três dimensões (3D), o que torna suas qualidades passíveis de serem percebidas, inclusive na interação textual que compreende escrever comandos e receber respostas, tal como ocorre no jogo Zork (Figura 19). Assim, de forma mais elementar, pode-se dizer que o ciberespaço aparece em diferentes formatos e plataformas, enquanto espaço relacional que permite o armazenamento, a recuperação e a navegação interativa por informações (dados).

O desenvolvimento de diferentes tipos de equipamentos que permitem acessar e visualizar esses dados foi, de certa forma, responsável pelo aparecimento e maturação da idéia da existência de mundos virtuais no imaginário das pessoas e da criação da realidade virtual, enquanto campo de investigação. Segundo Dourish (2004a, p.38) “[...] na abordagem da realidade virtual, a interação acontece em um mundo fictício e gerado pelo computador; o usuário se move por este mundo, tanto por imersão ou, mais comum nesses dias, por meio de uma janela para o mundo em uma tela de computador" ${ }^{47}$.

Um retorno ao percurso da tecnologia digital, abordado no item 1.2, evidencia que esta noção está, diretamente, relacionada com fases específicas de seu desenvolvimento. Em especial, aquelas que trataram o computador pessoal como amplificador da mente e assistente na execução de tarefas, voltado não apenas para questões científicas e militares como também para atividades cotidianas relacionadas aos negócios e à vida privada.

A internet foi, segundo Wertheim (2001, p.167-168) espontaneamente apropriada por este discurso e permitiu o ciberespaço extrapolar as máquinas individuais e partir para

\footnotetext{
47 Do original em inglês: In the virtual reality approach, interaction takes place in a fictional, computergenerated world; the user moves into that world, either through immersion or, more commonly these days, through a window onto the world on a computer screen (DOURISH, 2004a, p.38).
} 
Bem-vindo a Zork.

Oeste da casa.

Você está num campo aberto a oeste de uma grande casa branca com uma porta de frente feita de tábuas. Há uma pequena caixa de correio aqui.

Interator> Vá para norte.

Norte da casa.

Você está diante do lado norte de uma casa branca. Não há portas aqui, e todas as janelas estão bloqueadas.

Interator> Leste.

Atrás da casa.

Você está atrás da casa branca. Num dos cantos da casa há uma pequena janela que está levemente entreaberta.

Interator> Abrir janela.

Com grande esforço, você abre a janela o suficiente para permitir sua entrada. Interator> Entrar.

Cozinha.

Você está na cozinha da casa branca. Uma mesa parece ter sido usada recentemente na preparaçāo de comida. Uma passagem conduz a oeste, e pode-se ver uma tenebrosa escadaria que leva para cima. A leste há uma pequena janela aberta. Sobre a mesa encontra-se um comprido saco marrom com cheiro de pimenta ardida.

Há uma garrafa sobre a mesa.

A garrafa de vidro contém:

Certa quantidade de água.

\section{Interator> Oeste.}

Sala de estar.

Você está na sala de estar. Há uma porta a leste, uma porta de madeira com escritas góticas esquisitas a oeste, que parece presa com pregos, e um grande tapete oriental no centro da sala...

Interator > Olhar sob tapete.

Em baixo do tapete há um alçapão fechado.

Interator > Mover tapete.

Com grande esforço o tapete é removido para um dos lados da sala. Uma vez movido o tapete, a tampa empoeirada de um alçapão aparece.

Interator > Abrir alçapão.

A porta abre relutantemente e revela uma frágil escadaria que desce para a escuridāo.

Interator $>$ Descer.

Está escuro como breu. É provável que você seja devorado por um monstro. Sua espada está emitindo um brilho azul pálido. Interator > Acender lampiāo.

O lampiāo está aceso.

Porão.

Você está num porão escuro e úmido com uma estreita passagem que conduz a leste e um túnel baixo e apertado que leva ao sul. A oeste vêse a parte de baixo de uma ingreme rampa metálica, na qual é impossivel subir. A porta do alçapão fecha-se com um estrondo e você ouve alguém trancá-la.

Figura 19: Criação de espaço pela navegação e engajamento dramático, exemplificado pelo jogo Zork (Fonte: Murray, 2001, p. 81 (acima.) e p. 86 (abaixo)) 
um crescimento exponencial, aparentemente, ilimitado. "Esse novo fenômeno 'global' emerge da interação da miríade de seus componentes interconectados, e não é redutível às leis puramente físicas que governam os chips e as fibras de que inevitavelmente provém", ou seja, a estrutura do ciberespaço não segue a mesma configuração dos elementos que o viabilizam. Essa peculiaridade, uma das principais características da tecnologia digital, é um dos fatores que confere maleabilidade para o espaço informacional, além de ser, costumeiramente, adotado como base para diversos discursos sociais associados ao ciberespaço. Além de fornecer a estrutura para a construção de mundos virtuais, tornou-se fundamento para a elaboração de idéias relacionadas, por exemplo, a arenas mentais coletivas, à possibilidade de uma existência imaterial e à emergência de comunidades virtuais.

Entre os estudos sobre o tema, é fácil encontrar os paladinos do ciberespaço, termo adotado por Wertheim (2001) para designar os promotores deste novo mundo. Como toda nova tecnologia, discursos entusiasmados com suas possibilidades são sempre sedutores e inevitáveis. O ciberespaço foi introduzido como um lugar aberto para todos, onde pessoas de todas as nações poderiam se misturar, no qual as barreiras de nacionalidade seriam superadas e o sonho de uma comunidade global se realizaria. Com ele, a tecnologia poderia realizar o sonho humano de transcender o corpo e encontrar a imortalidade assim que sua mente pudesse ser digitalizada. Sobretudo, o ciberespaço seria um lugar acima e além dos problemas de um mundo material conturbado, praticamente, "[...] um substituto tecnológico para o espaço cristão do Céu" (WERTHEIM, 2001, p.14).

Vale apontar ainda que o autor propõe uma análise na qual busca desvendar a origem dessas concepções quase religiosas do ciberespaço. Aponta que a cultura materialista, hegemônica desde o lluminismo, foi transposta para a compreensão do espaço físico enquanto quantificável e infinito, não deixando lugar para o espaço do espírito, da alma ou da psique. O mapeamento do macro/micro cosmos contribuiu para a imagem monista do mundo sustentada pela ciência, na qual apenas o espaço físico quantificável existe e, qualquer outra variante do espaço passou a ser entendida como categoria inválida do real (WERTHEIM, 2001).

Dessa forma, o autor sugere que essas concepções do ciberespaço, citadas no parágrafo anterior, podem ser interpretadas como resultado da busca da ciência para encontrar o ingrediente que ela mesma deixa escapar, ao reduzir a realidade a fórmulas matemáticas e leis naturais. Assim, “[...] a 'espiritualização' do ciberespaço é parte integrante de um padrão cultural muito mais amplo que é, ele próprio, uma reação a esse reducionismo rígido" (WERTHEIM, 2001, p.29). Em termos mais práticos, para Wertheim, esses cibersonhos não são visões escapistas de imortalidade ou 
relacionados à uma onisciência gnóstica, de forma que podem ser também entendidos, a partir de uma perspectiva mais pragmática de busca de aperfeiçoamento da vida mortal. Ainda sobre o ciberespaço, Wertheim (2001, p.207) destaca:

Em particular, o ciberespaço é exaltado como um espaço em que a conexão e a comunidade podem ser promovidas, enriquecendo com isso nossas vidas como seres sociais. Nessas visões, o ciberespaço torna-se um lugar para o estabelecimento de comunidades idealizadas que transcendem as tiranias das distancias e são livres de preconceitos de sexo, raça ou cor. Em outras palavras, esse é um sonho de ciberutopia.

Não há dúvidas de que o computador e a internet expandiram significativamente o contexto do habitar humano, introduzindo diferentes possibilidades de entendimentos, interações, experiências e interpretações àqueles que possuem acesso à tecnologia. Para entender estas transformações, logo após a difusão maciça da internet, em algumas sociedades, foram elaboradas análises sobre novos padrões de sociabilidade.

Segundo Castells (2003, p.98), a internet foi inicialmente associada a afirmações conflitantes e a um debate estéril sobre, entre outras questões, a desvinculação de localidade e sociabilidade, decorrente das comunidades virtuais. Além disso, muito foi falado sobre o possível isolamento social e o "[...] colapso da comunicação social e da vida familiar, na medida em que indivíduos sem face praticam uma sociabilidade aleatória, abandonando, ao mesmo tempo interações face a face em ambientes reais". Ao observar com mais cautela, o autor encontrou um cenário bem diferente.

Em primeiro lugar, Castells (2003, p.99) afirma que os usos da internet mostraram-se "[...] esmagadoramente instrumentais, e estreitamente ligados ao trabalho, à família e à vida cotidiana". A construção de identidades falsas resumiu-se àquelas pessoas que passam, justamente, por estas questões na vida como um todo, como acontece, por exemplo, com os adolescentes. A promessa de sociabilidade irrestrita das comunidades virtuais não se realizou, de forma que, no início, a maioria das pessoas apenas adicionaram interações online à relações sociais existentes. Com sua maturação, as comunidades virtuais chamaram atenção para novos suportes de sociabilidade que possibilitaram a manifestação de desejos latentes de libertação pessoal, em relação a valores e formas tradicionais de controle.

O que se manifestou, acima de tudo, foi a relação individualizada com a sociedade já presente na cultura ocidental, porém de forma conectada. "O individualismo em rede é um padrão social, não um acúmulo de indivíduos isolados. O que ocorre é que indivíduos montam suas redes, on-line e off-line, com base em seus interesses, valores, 
afinidades e projetos" (Castells, 2003, p.109). Logo, as pessoas, além da sociabilidade com base no lugar, na vizinhança, no trabalho e na família, passaram a criar laços com indivíduos que possuem os mesmos interesses, idéias e estratégias de vida, independentemente de sua localização, formando, deste modo, suas próprias redes egocentradas e comunidades personalizadas. Assim conclui o autor:

As redes on-line, quando se estabilizam em sua prática, podem formar comunidades, comunidades virtuais, diferentes das físicas, mas não necessariamente menos intensas ou eficazes na criação de laços e na mobilização. Além disso, o que observamos em nossas sociedades é o desenvolvimento de uma comunicação híbrida que reúne lugar físico e ciber lugar (para usar a terminologia de Wellman ${ }^{48}$ ) para atuar como suporte material do individualismo em rede (CASTELLS, 2003, p.109-110).

Uma passagem pelos discursos associados ao ciberespaço torna perceptível a complexidade que as questões relacionadas à tecnologia digital adquirem, uma vez que são entrelaçadas no tecido social. Sonhos, crenças, esperanças e valores são necessariamente adicionados, e a ideologia tecno-científica, por si só, passa a ser insuficiente para lidar com essas demandas. Porém, no lugar de utilizar estes ciclos para questionar sua limitação ou sua validade, o homem do pensamento instrumental e da fé no progresso parece utilizar o atual contexto tecnológico para propor mais uma forma de salvação. Uma vez superada a ciberutopia e a possibilidade de construção de uma nova sociedade desmaterializada, que estaria além dos problemas do mundo material, começam a ser identificados discursos que promovem as cidades inteligentes (Greenfield, 2013). Trata-se de concepções de urbanidade diretamente relacionadas com os avanços identificados na terceira década do computador pessoal, conforme tratado no item 1.2.2. Nessa abordagem, ao mesmo tempo que o poder computacional passa a ser distribuído por múltiplos objetos e não se restringe mais ao computador pessoal, verifica-se o aumento da ubiquidade e da pervasividade da conectividade entre os aparatos.

Por mais que existam diversas maneiras de consolidar novas idéias e integrá-las ao contexto cotidiano, a partir de um exame realizado por Greenfield (2013), é possível destacar a esterilidade e a superficialidade dos discursos elaborados e propagados por grandes empreendedores da tecnologia digital. Sua crítica é construída, a partir da análise de projetos utilizados frequentemente como modelos canônicos de inserção tecnológica nas cidades. Em especial, explora o discurso encapsulado em desenvolvimentos urbanos completos, tais como Songdo City ${ }^{49}$ (Korea), Masdar City ${ }^{50}$

\footnotetext{
48 Aqui Castells (2003) faz referência a Barry Wellman e colegas, autores de diversos trabalhos sobre a vida no mundo conectado. Entre outros, organizou os livros Networks in the Global Village (1999), e Internet in Everyday Life (2002).

49 Songdo International Business District (SIBD), é um desenvolvimento urbano de $53.4 \mathrm{~km} 2$ para 500.000 habitantes. Seu discurso de marketing inclui desde controle biométrico de acesso até entrega de mercadorias
} 
(Abu Dhabi) e PlanlT Valley ${ }^{51}$ (Portugal). A intenção de Greenfield é elucidar que tipo de espaço é essa cidade inteligente de acordo com o discurso de quem a concebe e produz, uma vez que as grandes empresas de tecnologia estão se tornando em grande parte responsáveis tanto pelos sistemas técnicos dessas cidades, quanto pelo discurso teórico que as fundamentam.

Se este corpo de retórica é levado totalmente a sério pelos vários tomadores de decisão, pelo público e por outras pessoas que são expostas a ele, se ele que qualquer maneira instruem a alocação de escassos recursos orçamentários e atencionais - e indicadores atuais sugerem que ele é e faz - torna-se extremamente importante determinar o que exatamente ele está dizendo. Como essas empresas definem a cidade inteligente? E o que, exatamente, é a natureza da proposta de valor que eles acreditam estar oferecendo?52 (GREENFIELD, 2013, n.p.)

Como já abordado anteriormente, no item 1.1 desta tese, é sempre importante esclarecer os comprometimentos ideológicos e teóricos, a partir dos quais idéias e pensamentos são elaborados. Para Greenfield (2013, n.p.) as cidades inteligentes representam um movimento retórico específico em um contexto maior de possibilidades, "[...] é quase exclusivamente um discurso sobre a instrumentalização do tecido urbano e de quantificação de processos municipais, especificamente para a facilidade e eficiência de gerenciamento" ${ }^{\prime 53}$. Porém, assinala que ignorar os discursos utilizados para sua promoção é ser ingênuo à forma como as idéias são propagadas pela rede e aos processos de produção de valor no mundo contemporâneo. Seu estudo torna-se ainda mais relevante, uma vez que idéias difundidas por grandes empresas de incorporação imobiliária e tecnológica, normalmente, possuem um alcance maior do que aquelas presentes em discursos críticos e engajados.

totalmente automatizada, passando por telas de vídeo conferencia que ocupam paredes inteiras e displays de propaganda que se adaptam em tempo real às mudanças de posição da audiência (GREENFIELD, 2013). Mais informações sobre o projeto original podem ser encontradas em: <http://www.songdo.com> Acesso em: 25 nov. 2013.

50 Masdar City é um projeto desenvolvido pelos arquitetos Foster + Partners, no qual são previstos 40.000 habitantes e 50.000 trabalhadores em, aproximadamente, $6 \mathrm{~km} 2$. 0 interior é provido de todos os aparatos tecnológicos mais recentes de controle de acesso e gerenciamento de energia. 0 diferencial do projeto encontra-se no espaço entre os prédios, para o qual uma frota de veículos autônomos será responsável pelo deslocamento das pessoas no distrito, de forma que automóveis tradicionais não serão necessários (GREENFIELD, 2013). Mais informações sobre o projeto original podem ser encontradas em: <http://masdarcity.ae> Acesso em: 25 nov. 2013.

51 PlanIT Valley ocupará $6.7 \mathrm{Km} 2$ e abrigará 225.000 habitantes. Utilizará um Sistema Operacional Urbano unificado responsável por coordenar todos os passos de seus habitantes. A utilização de energia, mobilidade, controle de acesso, trabalho, lazer e entretenimento serão todos mediados por uma mesma plataforma digital (GREENFIELD, 2013). Mais informações sobre o projeto original podem ser encontradas em: <http://planitvalley.org/> Acesso em: 25 nov. 2013.

52 Do original em inglês: If this body of rhetoric is taken at all seriously by the various decision makers, publics and others who are exposed to it, if it in any way informs the allocation of scarce budgetary and attentional resources - and current indications suggest that it is and does - it becomes extraordinarily important to determine just what it is saying. How do these enterprises define the smart city? And what, exactly, is the nature of the value proposition they believe they are offering? (GREENFIELD, 2013, n.p.).

53 Do original em inglês: it's almost exclusively a discourse about the instrumentation of the urban fabric and the quantification of municipal processes, specifically for ease and efficiency of management (GREENFIELD, 2013, n.p.). 
A análise de Greenfield (2013, n.p.) aponta o caráter genérico dos projetos em questão. Os locais, nos quais serão implantados são espaços vazios, sem qualquer desenvolvimento urbano prévio. O tempo, a partir do qual suas previsões são elaboradas, é um tempo que está próximo e é, praticamente, inevitável, mas que ainda não chegou. Os discursos são sempre sustentados com fatos que irão e poderão acontecer em um futuro idealizado e não a partir de contextos já existentes. A tecnologia que será utilizada é sempre a mais atual, como se a especificidade dos provedores, dos tipos de aplicação e das interfaces, que se atualizam constantemente e nem sempre são compatíveis umas com as outras, fossem irrelevante. Tal arbitrariedade possui uma motivação, já que "[...] apenas propondo instalar tecnologias genéricas em paisagens genéricas em um futuro genérico podem os defensores evitar chocarem-se com as intrincadas complexidades que surgem imediatamente após tecnologias reais serem implantadas em locais existentes" ${ }^{\prime 54}$.

De um modo geral, essas cidades inteligentes nada têm a ver com a riqueza, a multiplicidade e o processo de formação tradicional das cidades. Ao contrário, seu programa é rígido e superespecificado no sentido que todos os usos possíveis são previstos e engessados, o que sugere uma concepção estática do futuro na qual, uma vez lá, fica-se lá. Os modelos de otimização adotados tratam as cidades como se fossem uma máquina cuja performance deve ser melhorada, como se a eficiência fosse a forma mais completa de julgar processos urbanos.

A otimização é proposta sempre para benefício dos administradores e para a apropriação privada do espaço e não com o objetivo de reforçar a cultura local e a apropriação pública dos espaços. Trata-se da exacerbação do positivismo lógico que pressupõe a possibilidade do conhecimento total do mundo, dos hábitos, das vontades e necessidades das pessoas, por meio de fórmulas e leis naturais, ou seja, da matemática. Isso tudo construído em plataformas proprietárias, com acesso restrito aos códigos, o que limita de forma significativa como os sistemas são usados, o que é possível extrair deles, como se dá a contribuição das pessoas e como pode ser reapropriado (GREENFIELD, 2013).

Simplificando a análise de Greenfield (2013), é possível especular que, se o homem com seus aparatos tecnológicos não foi capaz de criar um cibermundo perfeito, no qual as pessoas encontrariam a felicidade plena, com certeza agora ele será capaz de criar cidades perfeitas ou arrumar a desordem daquelas existentes, por meio do gerenciamento automatizado e inteligente de seus fluxos de matéria, energia e

\footnotetext{
54 Do original em inglês: Only by proposing to install generic technologies on generic landscapes in a generic future can advocates avoid running afoul of the knotty complexities that crop up immediately any time actual technologies are deployed in existing places (GREENFIELD, 2013, n.p.).
} 
informação. Nesta ocasião, mudam os atores e o cenário, mas a história contada é, praticamente, a mesma. Assim sendo, o grande desafio é imaginar como ir além desses discursos e ser capaz de construir outras histórias que possuam, como enredo, diálogos entre a tecnologia digital e o tecido social, abarcando tanto suas complexidades quanto particularidades.

\subsubsection{Conexões contextualizadas}

Diferente do discurso tecnocrático que permeia a noção de ciberespaço e os projetos das cidades inteligentes, McCullough (2004, p.xiii) aponta para uma abordagem distinta, na qual "[...] a computação pervasiva tem que ser inscrita na complexidade social e ambiental dos ambientes físicos existentes". Em sua perspectiva, na qual os lugares encontram-se no primeiro plano, a complexidade e as estruturas do mundo devem ser entendidas e não superadas. Trata-se de

[...] procurar o caminho do meio entre a uniformidade universal, que tem sido típica da alta tecnologia, e um desejo local de pertencer completamente a um lugar, que tem sido tipicamente antitecnologia. [...] Filosoficamente, isso reflete uma mudança profunda de utilizar a tecnologia para superar as limitações ambientais para utilizá-las para entendê-las e viver mais efetivamente com elas 55 (McCULLHOUGH, 2004, p. 173).

Para trafegar por este meio termo são necessárias abordagens do contexto contemporâneo que ofereçam múltiplas perspectivas e considerem os diversos elementos que compõem a sua complexidade, e não apenas a extrapolação paralela de pontos específicos ou de novas tendências. McCullough (2004, p.176), ao conferir enfoque especial ao lugar, o faz em contraponto ao conceito moderno de espaço que, seja por meio das construções científicas, teológicas ou arquitetônicas, caracteriza-se pela abstração, pelo absoluto, extensível e pela objetivação universal. Em sua perspectiva, o design de aparatos computacionais deve envolver representações não reducionistas e mais qualitativas e subjetivas de lugares e comunidades. Assim sendo,

0 apoio à forma que nós pertencemos a múltiplos espaços e comunidades deve aperfeiçoar nossos diálogos com o quê esses lugares e comunidades são. Um lugar não é apenas algumas coordenadas posicionais. Comunidade não é apenas uma lista de endereços de comerciantes. Pelo contrário, eles são percepções subjetivas e complexas nas quais a natureza das interações

\footnotetext{
55 Do original em inglês: [...] seek a middle way between a universal uniformity, which has been typical of high technology, and a local desire for completely belonging to one place, which has typically been antitechnology. (...) Philosophically, this reflects a profound shift from using technology to overcome environmental limitations toward using it to understand and live more effectively within them (McCULLOUGH, 2004, p. 173).
} 
mediadas desempenham um papel vital56 (McCULLHOUGH, 2004, p. 190)

Perspectivas que relacionam a informação e o ciberespaço com espaços e lugares têm recebido crescente ênfase, uma vez que a computação tem sido, gradativamente, espalhada em configurações outras além dos computadores pessoais. Segundo Santaella (2008), esses novos formatos possibilitam encontros com a tecnologia em situações distintas e, com isso, chamam atenção para a interrelação entre o ciberespaço e a vida cotidiana, criando, assim, a necessidade de entender diferentes contextos de uso. Entre as recentes possibilidades tecnológicas, Shepard (2011) destaca a infraestrutura composta pelos aparatos móveis que, aos poucos, foram integrados aos sistemas de comunicação e informação sem fio e, posteriormente, dotados de serviços de georeferenciamento e localização (em inglês location-based services, LBS). Uma vez que a adoção desses tipos de aparatos móveis é intensificada, a maneira como são utilizados ganha relevância no que tange a experiência do espaço urbano. Juntamente com formas geométricas e composição material, a conexão e a informação tornam-se, também, questões a serem consideradas em seu entendimento e agenciamento.

Os aparatos móveis, tais como tocadores de música e telefones celulares reconfiguram, constantemente, a relação com o contexto daqueles que os utilizam, chegando a ser denominados máquinas de território (territory machine), por sua capacidade de transformar qualquer espaço em um espaço pessoal e personalizado (SHEPARD, 2011) e por tornar cinzenta a gradação entre instâncias públicas e privadas. Estudos envolvendo o iPod, por exemplo, destacam a personalização da cidade, por meio de trilhas sonoras individuais; o estabelecimento de diferentes níveis de privacidade, de acordo com a forma de utilização do aparato; e, até mesmo, a possibilidade de se mover pela cidade sem necessariamente se envolver com o que acontece ao redor, evitando atenção não desejada, ao parecer ocupado e entretido com seu dispositivo pessoal. "Então, na verdade, o iPod se torna uma ferramenta para a organização do espaço, tempo e dos limites ao redor do corpo no espaço público" (SHEPARD, 2011, p.25).

Segundo Lemos (2007), os sistemas de georeferenciamento e localização, também denominados de mídias locativas, oferecem subsídios importantes e alteram significativamente a experiência espacial. "Esses aparatos fornecem informações específicas à localização, hora do dia / ano, e das preferências ou perfil de um indivíduo, grupo ou rede" (SHEPARD, 2011, p. 25). Além de fornecer informações

\footnotetext{
56 Do original em inglês: Supporting the way we belong to multiple spaces and communities has to improve our dialogues on what those places and communites are. A place is not just some positional coordinates. Community is not just a marketer's mailing list. Rather these are complex, subjective perceptions in which the nature of mediated interactions play as a vital role (McCULLOUGH, 2004, p. 190).
} 
específicas e alterar forma como a cidade é percebida, esses sistemas também possibilitam que qualquer pessoa contribua para camadas de informação sobre determinadas localidades. Portanto, a incorporação de conteúdo informacional a contextos específicos faz emergir novas maneiras de acessar, dividir e distribuir informações, no ambiente urbano. De um modo geral, considerando o uso de aparatos móveis e computadores portáteis, no ambiente urbano, diversas dinâmicas podem ser observadas.

A procura por hotspots faz as pessoas se sentarem em um lugar em vez de outro; a troca de telefonemas e SMS cria um novo movimento nas ruas e novas formas de sincronicidade ou encontros; os métodos atuais de localização e mapeamento mudam a forma como as pessoas vêem e interagem com a estrutura da cidade; ao acesso à informação sobre mobilidade em blogs, micro-blogs, ou software sociais alteram como as pessoas produzem conteúdo sobre sua experiência e a conecta a suas comunidades. Essas tecnologias estão produzindo um novo ritmo para a vida cotidiana, e novas mobilidades dentro de lugares ${ }^{57}$ (Lemos, 2008, p. 98).

Com o objetivo de compreender os impactos e as possibilidades das principais mídias locativas, Lemos (2007) propõe uma tipologia, a partir de funções que podem ser incorporadas a dispositivos móveis, e elenca quatro categorias: 1) a realidade móvel aumentada: (do inglês Mobile Augmented Reality Applications - MARA) abrange as aplicações que fornecem informações sobre determinada localidade ou objeto, quando identificados, por exemplo, por imagens ou por coordenadas geográficas. Outro exemplo de aplicação inclui o aviso da presença de amigos na proximidade; 2 ) os usos voltados para o mapeamento/monitoramento: consistem na utilização dos recursos disponíveis com o objetivo de demarcar de movimentações no espaço urbano; 3) As geotags: abrem a possibilidade para a inclusão de informação em mapas passíveis de serem acessados por dispositivos móveis; 4) As anotações urbanas: compreendem a indexação de diversos tipos de mensagens a localidades.

Entendidas em suas especificidades, as mídias locativas fornecem os meios para o estabelecimento de uma relação entre contextos e dispositivos computacionais, até antes, inédita (LEMOS, 2007). Além das referências tradicionais das cidades, vinculadas a marcas territoriais fixas, somam-se novas práticas comunicacionais e eventos informacionais dinâmicos embarcados nos objetos e nas localidades. De certa forma, tal fato estimula a inclusão e discussão de questões relacionadas à incorporação da

\footnotetext{
57 Do original em inglês: The search for hotspots makes people sit in one place instead of another; the exchange of phone calls or SMS creates a new movement on the streets and new forms of synchronicity or meetings; the current methods of locating and mapping change the way people view, and interact with, the city structure; access to information on mobility in blogs, micro-blogs or social software changes the way people produce content about their experience and links them to their community. These technologies are producing a new pace to everyday life, and new mobilities within places (LEMOS, 2008, p. 98).
} 
tecnologia, a partir das especificidades de localidades e de indivíduos, ou seja, de contextos específicos de uso. Por outro lado, é necessário cuidado com concepções estáticas de contexto que o reduzem a um problema de quantificação e representação.

Segundo Dourish (2004b), dependendo da perspectiva adotada, contexto pode ser tanto uma localização geográfica acrescida da descrição do que está ao redor daquele ponto, quanto algo que emerge e é sustentado por ações e interações, enquanto elas acontecem. A diferença entre estes dois entendimentos não é trivial, ao contrário, é resultado de concepções fundamentalmente distintas da realidade que, segundo Dourish (2004b, p.21), são incompatíveis. A primeira abordagem é, tipicamente, positivista e deriva da tradição racional, empírica e científica do pensamento, caracterizada pela redução de fenômenos a modelos simplificados que capturem padrões subjacentes. A segunda é fenomenológica, na qual “[...] fatos sociais são propriedades emergentes de interações, não pré-dadas ou absolutas mas negociadas, contestadas, e sujeitas a processos contínuos de interpretações e reinterpretações". A incompatibilidade dessas perspectivas deriva dos pressupostos e comprometimentos que cada uma reflete, como apresentados na Tabela 1 , a seguir:

\begin{tabular}{|c|c|}
\hline Contexto - segundo o positivismo & Contexto - segundo a fenomenologia \\
\hline $\begin{array}{l}\text { Um tipo de informação que pode ser definida, } \\
\text { codificada e representada; }\end{array}$ & Uma propriedade relacional; \\
\hline Delineável e previsível com antecedência; & Definido dinamicamente durante as atividades; \\
\hline Estável uma vez que definido; & Particular para cada ação; \\
\hline $\begin{array}{l}\text { Separado da ação, um palco onde as coisas } \\
\text { acontecem. }\end{array}$ & $\begin{array}{l}\text { Surge da ação, é ativamente produzido, mantido e } \\
\text { enacted. }\end{array}$ \\
\hline
\end{tabular}

Tabela 1: Comparação sistemática entre a perspectiva positivista e fenomenológica de contexto, de acordo com as definições delineadas por Dourish (2004b, p.21-22)

A análise do autor é extremamente relevante uma vez que o discurso e a prática tecnológica passou a incorporar contextos como possibilidade de inserção da computação, tal como ocorre com as mídias locativas. A abordagem que propõe, expande a noção técnica tradicional de contexto enquanto simplesmente um novo problema a ser codificado, representado e explorado, ou como uma nova possibilidade de expansão do domínio tecnológico. Para Dourish (2004b, p.28), "[...] a importância do contexto não é o que ele é, mas o que ele faz na interação - o papel que ele desempenha e as maneiras que ele é sustentado e manipulado". A questão é que a perspectiva positivista é insuficiente para a elaboração de aplicações tecnológicas que não sejam as pragmáticas, ou seja, voltadas para a realização de objetivos bem delineados e definidos. Já os pressupostos com os quais o autor elabora seu discurso, abrem a possibilidade de conceber alternativas que permitam a negociação e evolução de sistemas de ações e significados, durante a interação das pessoas com sistemas informacionais. 
Lugares, mídias locativas e contextos são questões-chave para a descompressão da realidade imposta pelo pensamento puramente tecnológico. A essas, inúmeras outras poderiam ser adicionadas na busca de compreender aspectos do rearranjo dinâmico e complexo da sociedade informatizada. Contudo, é também importante destacar que uma ênfase exagerada nas mídias locativas ou em qualquer outra nova aplicação, ou mesmo nos efeitos da tecnologia de forma generalizada, apesar de elucidar diversos aspectos e possibilidades de grande relevância, pode acarretar na redução da complexidade das atuais transformações sociais e tecnológicas aos recursos oferecidos unicamente pela infra-estrutura informacional.

Graham e Marvim (2001) argumentam que, para entender a natureza da complexidade das dinâmicas urbanas contemporâneas, a própria rede informacional deve ser entendida como parte de uma rede maior, no caso, a rede de redes de infraestruturas que (pelo menos na teoria) é o que integra e garante certa coesão para bairros, cidades, regiões, países e o mundo como um todo. Para esses autores, o fluxo constante dos processos urbanos é constituído por várias paisagens infraestruturais sobrepostas que sustentam a mediação entre natureza, cultura e produção da cidade. Estas, apesar de apresentarem características singulares, não são separadas e autônomas, ao contrário, "[...] elas dependem um do outro e co-evoluem estreitamente em suas relações com o desenvolvimento urbano e espaço urbano" (GRAHAM; MARVIM, 2001, p. 8). É com esta premissa que elaboram sua leitura crítica da interrelação entre as diferentes redes de infraestrutura que dão suporte às atividades cotidianas nas cidades. Assim,

Quando nosso foco analítico centra em como as redes de fios, dutos, túneis, conduites, ruas, rodovias e técnicas que entrelaçam e infundem as cidades são construídas e utilizadas, o urbanismo moderno emerge como um processo sócio-técnico extraordinariamente complexo e dinâmico. A vida urbana contemporânea é revelado como uma interrelação ininterrupta e dinâmica entre inúmeras escalas diferentes, do corpo ao globo. Tais interações dinâmicas entre distâncias e entre escalas, mediadas pelas redes de telecomunicações, transporte, energia e água, são as forças conectivas que conduzem muitos dos debatidos processos de globalização ${ }^{58}$ (GRAHAM; MARVIM, 2001, p. 8).

As redes de infra-estruturas, particularmente, desde a II Guerra Mundial, são normalmente assumidas como dadas, a priori, oferecidas pelo governo ou por

\footnotetext{
58 Do original em inglês: When our analytical focus centres on how the wires, ducts, tunnels, conduits, streets, highways and technical networks that interlace and infuse cities are constructed and used, modern urbanism emerges as an extraordinarily complex and dynamical sociotechnical process. Contemporary urban life is revealed as a ceaseless and mobile interplay between many different scales, from the body to the globe. Such mobile interactions across distances and between scales, mediated by telecommunications, transport, energy and water networks, are the driving connective forces of much-debated processes of globalization (GRAHAM; MARVIM, 2001, p. 8).
} 
monopólios regulamentados, que oferecem serviços básicos com qualidade e custo padronizados, sempre com a instância pública em primeiro lugar (GRAHAM; MARVIM, 2001, p. 8-9). Essa ideologia tende a negligenciar a dinâmica complexa das relações e dos interesses que direcionam sua forma e implementação. O perigo é que, a partir daí, pode-se desdobrar facilmente tanto discursos deterministas, nos quais as mudanças urbanas são causadas pelo desenvolvimento da infraestrutura e revoluções são identificadas com base em infraestruturas específicas, quanto em discursos hipotéticos de como a sociedade poderia ser caso sua distribuição fosse totalmente homogênea, como se as transformações só estivessem esperando o acesso ser disponibilizado.

Essa perspectiva idealista do pós-guerra, quando contextualizada em uma realidade maior, dá lugar a uma série de questões de extrema relevância. Ela ignora, por exemplo, a emergência de inúmeros espaços e redes especializadas, privatizadas e customizadas, que transformam as infraestruturas em mercadorias disputadas por empresas privadas internacionais. Novos mercados competitivos e lucrativos passam a substituir os monopólios regulamentados com "[...] estilos altamente fragmentados e diferenciados de prestação de serviços com geometrias e geografias altamente complexas e muitas vezes ocultas"(GRAHAM; MARVIM, 2001, p. 14). Com isso, surgem os espaços premium, altamente conectados globalmente mas que, em certa medida, contribuem para o aumento da segregação local. Acerca dessas reflexões, acrescentase ainda que:

Espaços valorizados são, assim, cada vez mais definidos por suas conexões aceleradas com outros lugares, como revela qualquer exame das intensas conexões de transporte, telecomunicação e energia entre as partes dominantes das cidades 'globais'. Ao mesmo tempo, no entanto, redes de infra-estruturas premium e de alta capacidade ignoram locais menos favorecidos e intermediários, como o que Castells chama de 'usuários redundantes'. Muitas vezes, tal negligencia e desconexão estão inseridas no design das redes, tanto em termos da geografia de pontos que conecta ou não, tanto em termos do controle exercido sobre quem ou o que pode fluir através das redes ${ }^{59}$ (GRAHAM; MARVIM, 2001, p. 15).

Para entender a relação entre tecnologia e sociedade, segundo Graham e Marvim (2001), é importante desenvolver um urbanismo em rede crítico, no qual a atenção às infraestruturas deve ser sistemática e não apenas reativa a crises e colapsos. Para isso,

\footnotetext{
59 Do original em inglês: Valued spaces are thus increasingly defined by their fast-track connections elsewhere, as any examination of the intensifying transport, telecommunications and energy links between the dominant parts of 'global' cities reveals. At the same time, however, premium and high-capability networked infrastructures often effectively bypass less favored and intervening places as what Castells ${ }^{59}$ calls 'redundant users'. Often such bypassing and disconnection are directly embedded into the design of networks, both in terms of the geographies of the points they do or do not connect, and in terms of the control placed on who or what can flow over the networks (GRAHAM; MARVIM, 2001, p. 15).
} 
é necessário entendê-las como um processo sinérgico, como uma cadeia de inovação interrelacionada na qual se entrelaçam híbridos sócio-técnicos, no lugar de agentes causais individuais cujos impactos são passíveis de serem identificados, estimulados, evitados ou consertados. A partir desta abordagem, o mundo globalizado e conectado ganha outra perspectiva, uma na qual a análise de uma série de processos indicam que, ao mesmo tempo que os espaços urbanos tornam-se translocalidades, marcadas por articulações e conexões multifacetadas e multidimensionais, sinalizam também, a materialização de uma fragmentação crescente de seu tecido social e material.

Assim sendo, um passo importante para que novas construções sejam possíveis é o entendimento de especificidades adquiridas pela tecnologia digital, uma vez que é introduzida no contexto social. Enquanto encubada em laboratórios, centros de pesquisa e discursos unidirecionais, corre-se o risco de levar em consideração apenas os aspectos positivos e lucrativos de cada desenvolvimento. Ao passo que, uma vez inseridos no tecido social, tornam-se evidentes os paradoxos inerentes à sua essência. Como aponta McCullough (2005, p.xiii), “[...] a tecnologia situada pode nos ajudar a gerenciar protocolos, fluxos, ecologias, e sistemas que formam a base de lugares valiosos; ou pode adicionar uma camada de desconfiança, excesso de informação, e uniformidade experiencial a eles" ${ }^{\prime 60}$. É justamente com essa tensão que a arquitetura interativa dialoga, e, para que sua abordagem não se restrinja a concepções superficiais ou unilaterais, é necessário explicitar, mesmo que brevemente, algumas questões controversas que envolvem a progressiva disseminação da tecnologia e ilustram sua natureza paradoxal.

\subsubsection{Paradoxos da tecnologia digital}

Segundo Ferreira (2010, p.1559), um paradoxo é uma afirmação que, apesar de aparentemente contraditória, mostra-se verdadeira. Por exemplo, ao mesmo tempo em que a liberdade é tida como uma qualidade essencial para a vida, as pessoas passam a vida cercando-se de condições que, ao mesmo tempo que propiciam a própria existência, limitam significativamente seu espaço de atuação. Da mesma forma, uma escolha é sempre uma renúncia, na medida em que a opção por uma alternativa significa, ao mesmo tempo, abrir mão de todas as outras possibilidades que poderiam vir a ser. Assim, falar em paradoxos é elucidar a natureza das coisas, deixar sempre claro o que se ganha e o que se perde em cada situação.

Quando analisadas de perto, as ações que envolvem a tecnologia digital são repletas de escolhas e renúncias, de oportunidades e limitações, de conexões e segregações, de

\footnotetext{
60 Do original em inglês: Situated technology may help us manage the protocols, flows, ecologies, and systems that form the basis of valued places; or it may add a layer of distrust, information glut, and experiential uniformity to them (McCULLOUGH, 2005, p.xiii).
} 
restrições e possibilidades. O próprio processo de digitalização das diferentes mídias ilustra, com clareza, a natureza desses paradoxos. Como ilustra a Figura 20, para transformar diferentes tipos e quantidades de energia (calor, luz, som) em escalas numéricas, é necessário converter ondas contínuas em variações numéricas. Por mais que esta transformação seja empreendida em grande resolução, será sempre uma aproximação, o que ocasionará, sempre, uma inevitável redução. Por outro lado, uma vez convertidos os sinais de diferentes formatos para um mesmo, abrem-se as possibilidades de armazenamento, transmissão, combinação e manipulação que só o meio digital oferece. Uma analogia pode ser feita com a questão da linguagem. Se todas as pessoas do mundo concordarem em utilizar o mesmo vocabulário e gramática para designar as coisas, o diálogo e a troca, entre diferentes culturas, tornam-se possíveis, por outro lado, corre-se o risco de anular toda a riqueza e especificidade dos diferentes modos locais de comunicação.
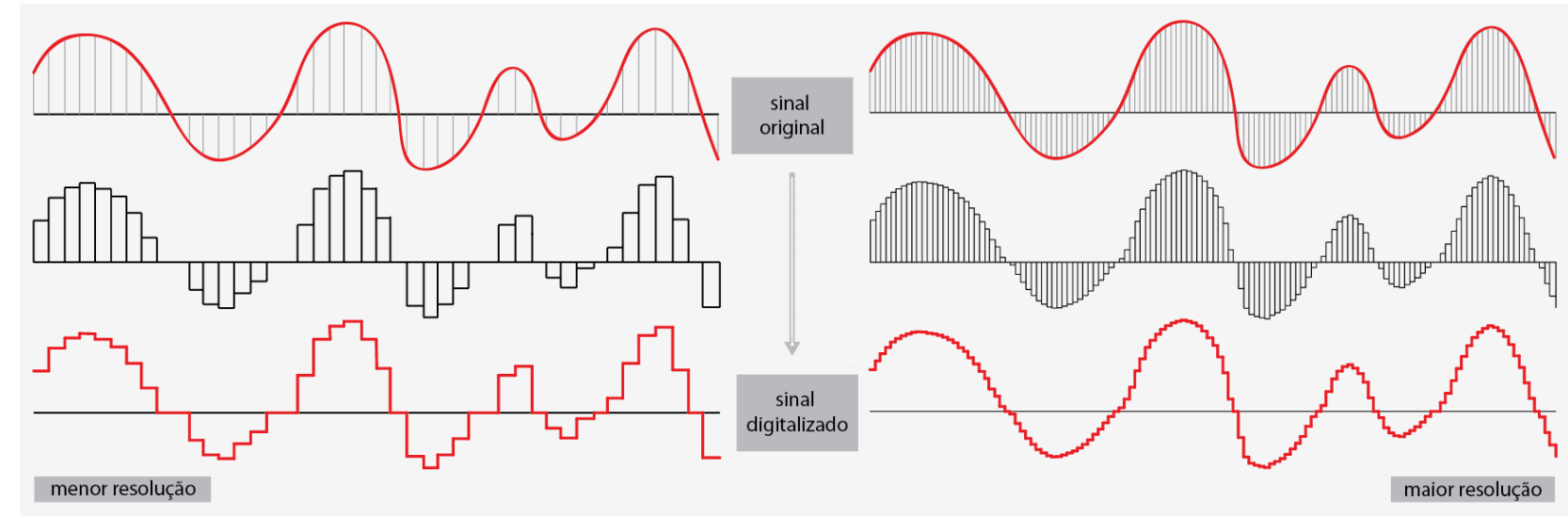

Figura 20: Conversão para o digital: das ondas contínuas são extraídas variações numéricas. Por mais que haja o aumento da resolução, o sinal sempre sofrerá redução. (Fonte: Gabriela Carneiro, 2013)

Estes paradoxos compreendem também a base da análise que Couchot (2003, p.14-27) elabora "[...] para melhor compreensão da evolução da arte e de suas relações estreitas com a tecnologia, uma tecnologia que está cada vez mais ligada à ciência e é cada vez mais invasora". Para isso, retorna à fotografia que, segundo sua abordagem, instaurou uma nova era da imagem com a inserção do automatismo nas artes figurativas, "[...] aliviando o fabricante de imagens de uma parte importante de seu trabalho". Com qualquer pessoa passando a ser capaz de produzir imagens semelhantes a modelos, os artistas foram forçados a desenvolver qualidades que o aparelho fotográfico não possuía, e a expressão da subjetividade foi o meio encontrado para contrabalancear a visão despersonalizada da imagem automatizada. Esse novo meio de percepção, criação e reprodução ofereceu ao homem novas possibilidades artísticas e de expressão da subjetividade, ao mesmo tempo que automatizou e popularizou a criação de imagens.

No que se refere à tecnologia digital, Couchot (2003, p.15-17-18), identifica as mesmas ansiedades, já que "[...] parece despojar o criador de toda singularidade e de toda 
expressividade e reduzir o ato de criação a puros automatismos maquinicos". Porém, observa que, com o numérico (digital), a presença mascarada da ciência pesa sobre o fazer artístico, mas, em compensação, abrem-se espaços e tempos promissores de descobertas e experimentações. Sobre a questão da expressão da subjetividade, o autor argumenta sobre a constante busca de equilíbrio das duas faces do mesmo sujeito, o sujeito-NÓS que tende sempre muito mais ao tecnicismo e o sujeito-EU "[...] que tenta resistir a essa dependência e redefinir sua própria identidade no decorrer de crises sucessivas que afetam violentamente o mundo da arte". No que diz respeito à arte numérica, é a subjetividade resultante do acasalamento híbrido entre o gesto (subjetividade) e o cálculo (razão científica) que mantém a "[...] terrível e fascinante ambiguidade" que por séculos tem nutrido a arte como um todo (COUCHOT, 2003, p.312).

A estrutura que sustenta a conexão mundial de computadores também ilustra a sobreposição de conceitos aparentemente antagônicos. As redes, ao mesmo tempo que simbolizam a conexão e a liberdade em nível global é, antes de tudo, resultado de uma estrutura de controle absoluto.

Segundo Galloway (2004, p.4), “[...] the most extensive 'computerized information management' system existing today is the Internet". Porém, muitas vezes, não é assim que ela é entendida.

É como para os críticos contemporâneos descreverem a Internet como uma massa de dados imprevisível - rizomática e sem organização central. Essa posição afirma que, como as novas tecnologias de comunicação são baseadas na eliminação do comando central e do controle hierárquico, resulta-se que o mundo está testemunhando um desaparecimento geral do controle enquanto tal ${ }^{61}$ (GALLOWAY, 2004, p.8).

Os argumentos de Galloway (2004, p.8) apontam para outra direção, para o autor, "[...] os protocolos são como o controle tecnológico existe, depois da descentralização". Como já mencionado, no Item 1.2.3, os protocolos consistem em padronizações de sinais que tornam possíveis a troca de mensagens entre aparatos computacionais. São eles que mantêm a regulação voluntária em um ambiente, aparentemente, desordenado e aleatório.

Em vez de práticas de governo sociais ou políticas, como fizeram seus antecessores diplomatas, os protocolos de computador governam como tecnologias específicas são negociadas, adotadas, implementadas e, finalmente, utilizadas pelas pessoas ao redor

\footnotetext{
61 Do original em inglês: It is common for contemporary critics to describe the Internet as an unpredictable mass of data - rhizomatic and lacking central organization. This positions states that since new communication Technologies are based of the elimination of centralized command and hierarchical control, it follows that the world is witnessing a general disappearance of control as such (GALLOWAY, 2004, p.8).
} 
do mundo. O que antes era uma questão de consideração e senso é agora uma questão de lógica e física ${ }^{62}$ (GALLOWAY, 2004, p. 7).

O que é comumente ignorado, no caso da internet, é que sua existência depende de dois protocolos totalmente contraditórios, porém complementares, com ilustra a Figura 21. Um - o TCP/IP - é responsável por transmitir dados eficientemente por meio da rede, e sua estrutura permite a conexão entre quaisquer duas máquinas de forma não hierárquica. O outro - o DNS - é uma central de dados distribuída, que relaciona nomes de web sites ao seu endereço, ou seja, à sua localização específica na rede física. Indica exatamente, por exemplo, em qual servidor estão os dados de uma página online de determinada empresa.

Figura 21: Estrutura "árvore invertida" do DNS e rede distribuída do TCP/IP. Para enviar pacotes de informação de um email para outro, primeiro é necessário determinar os endereços dos servidores para depois ocorrer a troca de informações. As informações são divididas em pacotes (packets) e estes seguem sempre o caminho mais eficiente para alcançar o destino. (Fonte: Gabriela Carneiro, 2013)
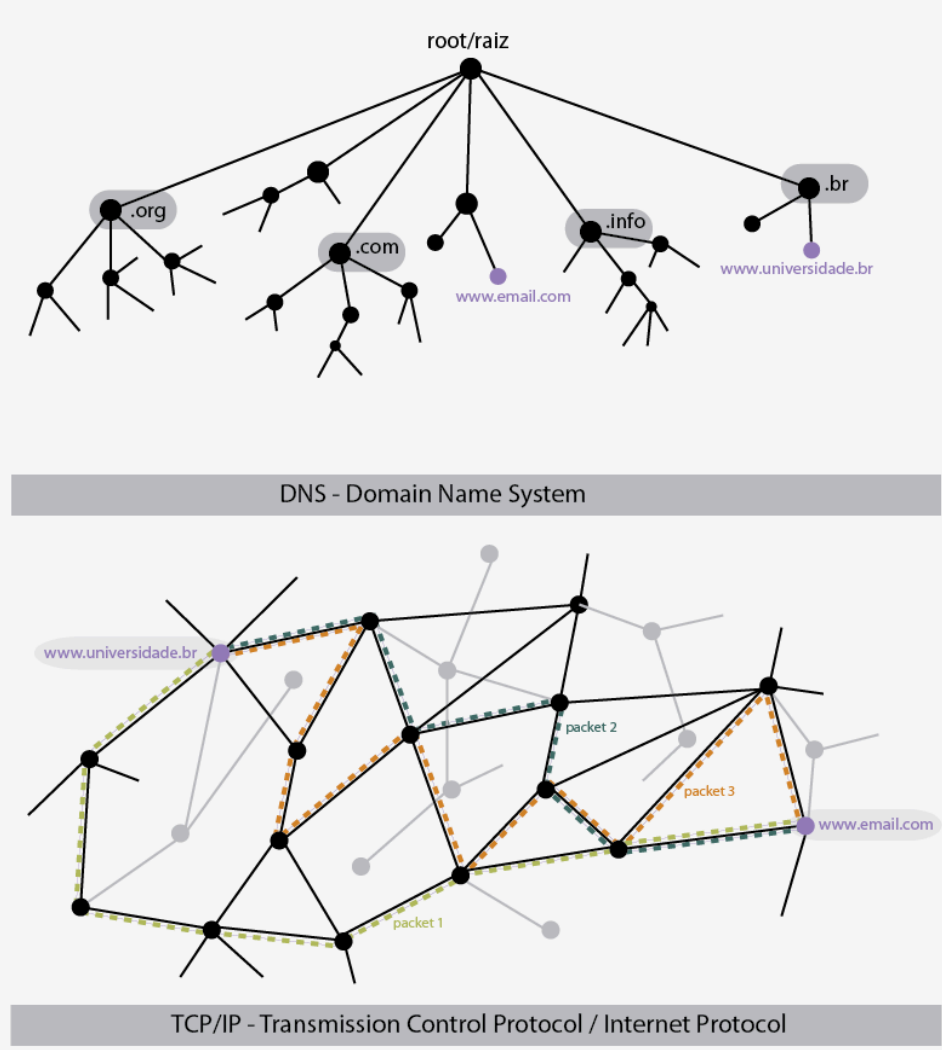

Uma vez que um clique é disparado, é necessário encontrar o local específico onde o web site está hospedado para que depois a transmissão de dados ocorra. A estrutura do DNS é totalmente hierárquica, no formato de uma árvore invertida e, por este motivo, cada galho desta árvore controla totalmente o que está abaixo dele. "Ironicamente, então, quase todos os tráfegos da Web devem submeter-se a uma estrutura hierárquica (DNS) para ter acesso à estrutura anárquica e radicalmente

62 Do original em inglês: Instead of governing social or political practices as did their diplomatic predecessors, computer protocols govern how specific technologies are agreed to, adopted, implemented, and ultimately used by people around the world. What was once a question of consideration and sense is now a question of logic and physics (GALLOWAY, 2004, p. 7). 
horizontal da Internet"63 (GALLOWAY, 2004, p.9). Tal fato paradoxal estende-se para, praticamente todos os protocolos utilizados na comunicação pelo meio digital.

Existem diferentes interpretações para as intencionalidades que direcionaram a concepção e implementação da internet. Para Castells (2003, p.139-141), ela foi criada, inicialmente, como um meio para a liberdade, que tem sido desafiada, progressivamente, por novas tecnologias de controle e regulações, transformando-a em um "[...] terreno contestado, onde a nova e fundamental batalha pela liberdade na Era da Informação está sendo disputada". Segundo Beniger (1986), apesar de sua análise anteceder a disseminação da internet, a implicação social mais importante da proliferação da digitalização é a convergência progressiva de todas as tecnologias de informação em uma infraestrutura única de controle em grande escala. Como descrita por Galloway (2004), a arquitetura da internet consiste, justamente, nessa composição abrangente e formalizada de protocolos voltadas para o controle preciso e eficiente de trocas de informações.

Durante os primeiros anos da existência mundial da internet, como afirma Castells (2003), o governo pouco podia fazer para controlar fluxos de informação; a liberdade de expressão podia difundir-se por meio do planeta; e a privacidade era protegida pelo anonimato; o entendimento de sua lógica deixa claro que o controle está em sua natureza. Para Galloway (2004), a tecnologia digital e os protocolos que a sustentam não são bons ou ruins mas, sim, perigosos e, por isso, sua natureza deve ser compreendida. O perigo fica ainda mais eminente cada vez mais, se as pessoas se alienarem desses processos e deixarem utilizar seu potencial, enquanto atores sociais ativos, agindo apenas como consumidores passivos. Afinal, "[...] hoje, objetos dotados de inteligência artificial nos permite fazer mais e mais por nós mesmos e pelos outros, mas ao mesmo tempo eles também nos deixam mais vulneráveis a serem usados" ${ }^{64}$ (SCHOLZ, 2011, p. 205). Isso é possível pois,

Aplicações de software podem ser superpostas em camadas a protocolos da Internet, tornando possível identificar rotas de comunicação e conteúdo. Com o uso dessas tecnologias, é possível violar a privacidade, e uma vez que se torna possível relacionar indivíduos com processos específicos de comunicação em contextos institucionais específicos, todas as formas tradicionais de controle político e organizacional podem ser lançadas sobre o indivíduo em rede (CASTELLS, 2003, p. 140).

\footnotetext{
${ }^{63}$ Do original em inglês: Ironically, then, nearly all Web traffics must submit to a hierarchical structure (DNS) to gain Access to the anarchic and radically horizontal structure of the Internet (GALLOWAY, 2004, p.9).

64 Do original em inglês: Today, objects imbued with artificial intelligence allow us to do more and more for ourselves and for others, but at the same time they also make us more vulnerable to being used (SCHOLZ, 2011, p. 205).
} 
Dentre as formas de controle que emergiram dos interesses entrelaçados do comércio e dos governos, segundo Castells (2003) podem ser elencadas as tecnologias de identificação, de vigilância e de investigação. As tecnologias de identificação possibilitam rastrear as atividades de computadores ou usuários específicos na rede. As de vigilância partem da identificação para interceptar mensagens, instalar marcadores que permitem o rastreamento de fluxos de comunicação e o monitoramento ininterrupto da atividade da máquina. A investigação toma partido das duas outras, porém armazena os resultados da vigilância em bancos de dados e os submetem a combinações, análises, agregações, de acordo com o objetivo e poder legal.

O uso das informações geradas por esses tipos de protocolos não se restringe ao governo e às questões de segurança nacional. Como indica Scholz (2011), existe toda uma indústria de mineração de dados que se torna cada dia mais proficiente e sofisticada em construir, usar e vender montagens e conjuntos de dados. "Os instrumentos com os quais esses dados são coletados encontram-se em grande parte escondidos, eles são pervasivos, e eles mudam tão rapidamente que está se tornando impossível a qualquer pessoa com um trabalho e uma família ficar a par deste processo" ${ }^{65}$ (SCHOLZ, 2011, p.206). Em diversos casos, a utilização de serviços gratuitos da internet é paga pela venda e disponibilização dos dados de quem os utiliza e de como os utiliza, e o lucro, gerado por sua comercialização, torna-se cada dia mais nebuloso. Trata-se da troca deliberada da privacidade e dos dados pessoais em nome da liberdade de uso.

Galloway (2004) argumenta que os esforços de resistência devem ser direcionados por meio dos protocolos e não contra eles, utilizando as vantagens e os poderes que sua estrutura controlada e distribuída conferem. Como exemplos de contravenções que utilizam os próprios protocolos, o ator cita os hackers e a mídia tática. Os primeiros incluem ativistas informacionais que dominam, profundamente, a linguagem e o código, e lutam pela liberdade da informação, rejeitando sempre situações nas quais seu acesso é restringido. A mídia tática compreende os usos políticos da tecnologia, que incluem desde a criação de campanhas para acesso mais democrático à internet até a dispersão de vírus de computadores com o objetivo de atrapalhar ou destruir sistemas de empresas e corporações.

De um modo geral, é importante entender que a tecnologia coloca paradoxos relevantes para serem questionados e não ignorados, e que estes se manifestem de maneira variável e relativa aos contextos específicos de prática. Como foi abordado, a

\footnotetext{
65 Do original em inglês: The instruments with which these data are collected are largely hidden from view, they are pervasive, and they are changing so rapidly that it is becoming impossible for anybody with a job and a family to stay abreast this process (SCHOLZ, 2011, p.206).
} 
digitalização converge os diferentes meios de comunicação às custas de sua redução, ao mesmo tempo que abre possibilidades de conexão, antes inexistentes.

O ciberespaço (imaterial) possui uma geografia descolada do território físico, porém depende de uma gigantesca e robusta estrutura material para existir. Essa infraestrutura é criada e gerenciada por governos e empresas que apenas o fazem com a certeza de que podem, de alguma maneira lucrar com ela, seja por meio do poder ou dinheiro, e o lucro, muitas vezes, vem da disponibilização gratuita de serviços. Usa-se a rede da mesma maneira que se é usado por ela.

Deste modo, acredita-se que é a ampliação da compreensão dessas questões, e das maneiras que elas se manifestam em contextos específicos, que deve nutrir os pensamentos e ações no mundo contemporâneo. O constante debate permite o balanço de prerrogativas e discursos dos quais podem surgir ações que levem à ampliação do presente, constantemente comprimido pela ideologia científica e tecnológica.

Neste sentido, as questões delineadas, ao longo deste capítulo, contribuem para o entendimento da arquitetura interativa como parte de um contexto maior e ligado a práticas intelectuais, tecnológicas e sociais. Estes são apenas alguns dos aspectos de uma trama maior na qual inúmeras outras questões podem ainda ser adicionadas, tensionadas e friccionadas. Mais do que pensar espaços inovadores e se apropriar das soluções tecnológicas disponíveis, a abordagem aqui adotada objetiva enfatizar a arquitetura interativa tanto como manifestação das inúmeras discussões colocadas até o momento, quanto um meio poderoso para designers e arquitetos participarem e contribuírem, ativamente, para a construção do presente e do futuro da sociedade. Assim, para a construção de uma prática engajada com questões atuais, o passo seguinte é entender suas especificidades e formas de manifestação, tema do próximo capítulo. 


\section{Fundamentos}

Falar sobre os fundamentos da arquitetura interativa significa esboçar aspectos particulares desse tipo de espaço. Essas características próprias levam a uma inicial diferenciação entre o interativo e o "não-interativo" como se fossem coisas opostas. Contudo, a intenção não é segregar a arquitetura em dois tipos, ou mesmo dar suporte a discursos que sustentam novos aspectos em detrimento de antigos. Ao contrário, acredita-se que o passado, ou seja, as discussões até hoje realizadas, os espaços já construídos e os materiais e métodos utilizados para tal, por mais controversos que pareçam ser ou que efetivamente sejam, são partes indissociáveis da essência do que é, por vezes, delineado como novo, inovador ou revolucionário.

Como foi apresentado no Primeiro Capítulo, a realidade é muito mais do que uma única sequência linear de causa e efeito, passível de ser dissecada e explicada. Nesse sentido, esboçar o que é específico da arquitetura interativa é, acima de tudo, alargar o entendimento geral dos espaços construídos pelo homem e das ações que ali acontecem, incluindo neles, questões trazidas pela tecnologia digital.

Recortes são necessários para estruturar o conhecimento das coisas. Deste modo, para introduzir o objeto a ser examinado, em um primeiro momento, é necessário descrever seu contexto imediato. Nesse caso, aspectos gerais da ligação entre arquitetura e tecnologia são esboçados, a partir de dois pontos de vista.

Primeiramente são delineadas suas relações no que tange o processo de pensamento, ou seja, como a tecnologia tem sido incorporada como ferramenta para pensar, visualizar e produzir arquitetura. Em seguida, são esboçados alguns aspectos históricos e práticos da incorporação da tecnologia no ambiente construído, ou seja, no produto arquitetônico. É neste segundo aspecto que se manifesta a arquitetura interativa, que , 
nesse sentido, diferencia-se da "não-interativa" pela inclusão de elementos computacionais e de comportamentos lógicos no espaço construído.

Por mais que o objeto deste estudo seja esse produto, de forma alguma descarta os novos meios e critérios de pensamento, afinal são deles que a arquitetura interativa se origina. Como já mencionado, essa diferenciação é feita com o intuito de alargar a compreensão da inter-relação e da complementaridade entre tecnologia e arquitetura, e não de contrapor opostos excludentes.

Postas essas relações, um último movimento é feito com o intuito de analisar aspectos que conferem coerência à arquitetura interativa enquanto uma particular forma de intervenção e de manifestação. Para isso, são esboçados dois aspectos que the conferem especificidade, os recursos materiais utilizados para implementá-la e seu comportamento.

Quanto ao primeiro, às soluções tradicionais de construção e implementação espacial somam-se os componentes computacionais e novos tipos de material cujas características físicas são passíveis de serem controladas pela computação. Além disso, esses mesmos recursos transformam os meios tradicionais utilizados para adicionar aspectos dinâmicos aos espaços, tais como a iluminação e o movimento (cinética), ao possibilitar a criação de estruturas dinâmicas com computação incorporada.

Falar sobre o segundo aspecto, o comportamento da arquitetura interativa, significa entender a natureza dos procedimentos lógicos que são implementados em sua estrutura. Independentemente das diversas definições do que conforma a essência da arquitetura, se são suas características fixas ou adaptáveis, a arquitetura interativa possui especificidades comportamentais.

Se a arquitetura "não-interativa" é entendida como algo fixo e imutável, a arquitetura interativa diferencia-se por ter como característica essencial o processamento de informações captadas por sensores, que controlam elementos dinâmicos específicos (os atuadores). Se é originalmente percebida como adaptável, de forma que diferentes usos podem alterar seu uso e significado, sua variação interativa, da forma como é entendida, nesta pesquisa, diferencia-se pelos tipos específicos de comportamentos que podem ser digitalmente implementados. Seu aspecto dinâmico é colocado não pelos novos usos ou pela revitalização, mas sim, pelos modelos de interação que são implementados em seus núcleos controladores. 
Assim sendo, ao esboçar as bases da arquitetura interativa, espera-se contribuir para a definição de um tipo de espacialidade que incorpora a tecnologia digital em sua estrutura física e que possibilita a implementação de comportamentos, fundamentalmente, distintos do comportamento de espaços "não-interativos". Nesse contexto, estrutura e comportamento precisam ser compreendidos e tratados como aspectos complementares de um mesmo fenômeno, caso contrário, corre-se o risco de resumir a arquitetura interativa à pura incorporação de elementos técnicos ou à desvinculação entre comportamento e contexto físico, como acontece, por exemplo, com as cidades inteligentes descritas no Item 1.3.1.

\subsection{Arquitetura e Tecnologia Digital}

A relação entre a arquitetura e o universo computacional desenvolveu-se, simultaneamente, com o desenvolvimento dos próprios computadores digitais. Ao longo das décadas de 1960 e 1970, mesmo com estas máquinas ainda restritas a laboratórios e universidades, alguns arquitetos já faziam experimentos com sua lógica e seus circuitos. Cada um, a seu modo, produziram tanto experimentos práticos, quanto profundas reflexões teóricas sobre como a computação digital de dados poderia, ou já afetava a arquitetura, seus contextos e seus processos. Atualmente, já na segunda década do século XXI, a pervasividade dos computadores nos processos de criação e produção de espaços não deixa mais dúvidas sobre a relevância do tema para a arquitetura. Segundo Glynn (2009, p.8),

Ao longo da última década, a prática da arquitetura foi radicalmente transformada por meio da aceleração digital e aguçamento da produção. Nenhum escritório foi deixado intocado pela revolução digital - talvez um clichê, já que o digital não é especial, nem mesmo excepcional. É a norma, o invisível, a camada ubíqua emaranhada por meio de tudo ${ }^{66}$.

Do digital para o físico, faz-se necessário fundamentar o contexto no qual a computação passou a ser utilizada para a criação de formas que evoluem com os arquitetos, para depois pensar de que modo a criação de formas que evoluem com as pessoas e os eventos que ocupam o espaço podem ser viabilizadas, no atual contexto. No decorrer das décadas, o espaços entre discursos extremos que envolvem a substituição do arquiteto pela máquina, por um lado, e a resistência em adotar métodos computacionais, por outro, foi ocupado em busca de um equilíbrio marcado

\footnotetext{
66 Do original em inlgês: Over the past decade, the practice of architecture has radically transformed through the digital acceleration and sharpening of production. No office has been left untouched by the digital revolutionperhaps a cliché, since the digital is not special, nor remarkable. It is the norm, the invisible, the ubiquitous layer threaded through everything (GLYNN, 2009, p.8).
} 
pela coexistência de intuição, criatividade, sistematização e racionalização de processo.

\subsubsection{Processo}

Christopher Alexander, Nicolas Negroponte e John Frazer, são apenas alguns nomes das primeiras gerações de arquitetos que adotaram pensamentos computacionais para lidar com o espaço construído. Os experimentos destes arquitetos buscaram explorar métodos para um entendimento aprofundado e científico da arquitetura. Suas intenções eram, em grande parte, baseadas na crença de que tal aproximação poderia levar ao desenvolvimento de uma arquitetura mais adaptada aos problemas de seu tempo, que cresciam, a cada dia mais, em complexidade. Segundo Alexander (1964, p.4),

Ao mesmo tempo em que os problemas aumentam em quantidade, complexidade e dificuldade, eles também mudam mais rápido que antes. Novos materiais são desenvolvidos o tempo todo, os padrões sociais alteram-se rapidamente, a própria cultura está mudando mais rápido como jamais mudou antes. ${ }^{67}$

Formado em matemática e arquitetura, o trabalho de Alexander (1964) baseia-se na busca de delinear modos de implementar o pensamento lógico no design e na arquitetura. Para isso, o autor propõe e explora um entendimento de lógica que vai além de sua propriedade dedutiva e fornece uma abordagem mais ampla do termo no qual, segundo o autor,

Preocupa-se com a forma de estruturas abstratas [...]. É função da lógica inventar estruturas puramente artificiais de elementos e relações. Algumas vezes uma dessas estruturas é próxima o suficiente de uma situação real para ser permitida representá-la. E assim, porque a lógica é tão bem desenhada, nós adquirimos uma visão da realidade que foi previamente denegada de nós68 (ALEXANDER, 1964, p.8).

Deste modo, Alexander (1971) busca desmistificar a lógica e propõe um raciocínio no qual ela coexiste com os aspectos intuitivos dos arquitetos. $O$ autor acredita ser esta a maneira mais propícia de se lidar com as complexidades latentes de seu contexto.

\footnotetext{
67 Do original em inglês: At the same time that the problems increase in quantity, complexity, and dificulty, they also change faster than before. New materials are developed all the time, social patterns alter quickly, the culture itself is changing faster than it has ever changed before (ALEXANDER, 1964, p.4).

68 Do original em inglês: It is concerned with the form of abstract strucutures [...]. It is the business of logic to invent purely artificial structures of elements and relations. Sometimes one of these structures is close enough to a real situation to be allowed to represent it. And then, because the logic is so tightly drawn, we gain insight into the reality which was previously withheld from us (ALEXANDER, 1964, p.8).
} 
Apesar de sua diagnosticada limitação, seu livro Notes on the Synthesis of Form ${ }^{69}$ e em

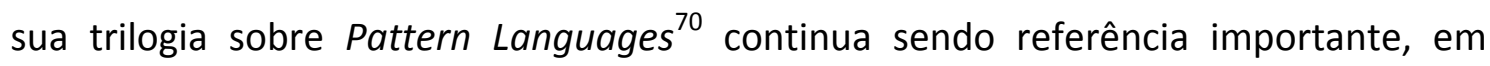
especial, para o design de softwares e linguagens computacionais (LEA, 1994). Na arquitetura, seu trabalho representou a introdução do pensamento sistêmico no processo de entendimento e manipulação de formas e espaços.

Da mesma forma que Alexander teorizava sobre a coexistência da intuição e da lógica, Negroponte (1970) explorava uma possível simbiose entre o homem (intuição) e a máquina (lógica). Em seu livro Architecture Machines aborda este tema sob uma forte influência da perspectiva adotada por Licklider, que já no final dos anos 1950, quando os computadores ainda eram controlados por cartões perfurados, visualizava o potencial computacional como um parceiro colaborativo no processo criativo. Segundo Licklider (1960, p. 1):

Na esperada parceria simbiótica, o homem irá definir os objetivos, formular as hipóteses, determinar os critérios, e realizar as avaliações. Máquinas computacionais irão fazer o trabalho rotinizável que deve ser feito para preparar o caminho para idéias e decisões no pensamento técnico e científico. ${ }^{71}$

É, então, neste contexto, que Negroponte (1970) apresenta o URBAN5 (Figura 22-23) um sistema gráfico para monitorar procedimentos de design. Neste sentido, a utilização de uma linguagem gráfica para o propósito de possibilitar uma relação simbiótica, entre homem e computador, foi primeiramente implementada por Sutherland, no início da década de 1960, com seu software Sketchpad, o qual "[...] permitia que um engenheiro gerasse designs sentando em um terminal gráfico interativo e manipulando desenhos exibidos na tela pela utilização de um teclado e

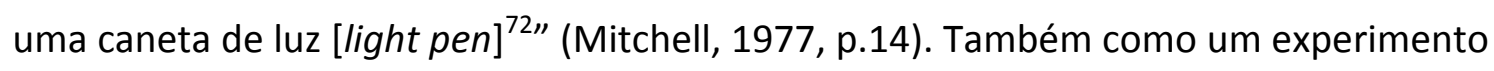
gráfico, o URBAN5 permitia que o arquiteto/usuário manipulasse, virtualmente, blocos de aproximadamente $3 \times 3$ metros para a criação de espaços. O computador, além de fornecer as vistas e perspectivas do espaço que estava sendo criado, analisava a interação entre os blocos e seu posicionamento, a partir questões intrínsecas às formas. Segundo o arquiteto:

\footnotetext{
${ }^{69}$ Notes on The Sinthesis of Form foi resultado do trabalho de doutorado de Alexander.

70 Pattern Languages é o título do Segundo volume da trilogia de livros escritas pelo arquiteto. 0 primeiro foi The Timeless Way of Building e o terceiro The Oregon Experiment.

71 Do original em inglês: In the anticipated symbiotic partnership, men will set the goals, formulate the hypotheses, determine the criteria, and perform the evaluations. Computing machines will do the routinizable work that must be done to prepare the way for insights and decisions in technical and scientific thinking (LICKLIDER, 1960, p.1).

72 Do original em inglês: Skecthpad allowed and engineer to generate designs by sitting at an interactive graphics terminal, and manipulating drawings displayed on the screen by use of light-pen and keyboard (MITCHELL, 1977, p.14).
} 
Além das características de sólido e vazio, cada cubo de dez pés (seja sólido ou vazio) possui recipientes pré-alocados para dez características que se referem a aspectos de luz solar, acesso ao exterior, à privacidade visual, à privacidade acústica, à usabilidade, ao acesso direto, ao controle de temperatura, à luz natural, à flexibilidade e à viabilidade estrutural. Todas essas qualidades são implicitamente atribuídas aos elementos. Em outras palavras, sem a permissão, intervenção ou mesmo conhecimento do usuário, o URBAN5 atribui, automaticamente, a ausência ou presença dessas características, usando uma geometria pré-definida para cada atributo ${ }^{73}$ (NEGROPONTE, 1970, p.81).
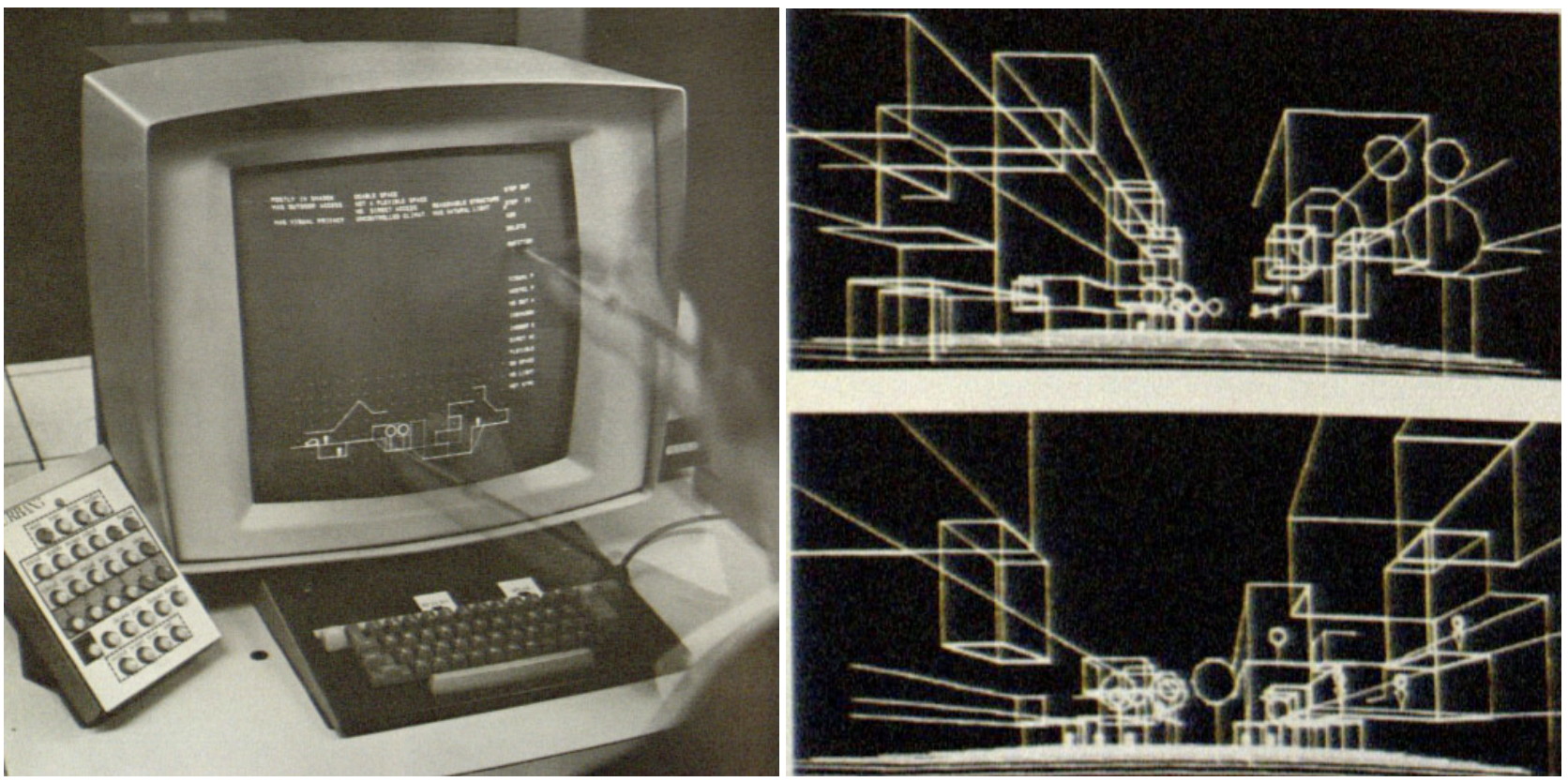

Figura 22-23: Aparatos utilizados para dar input de dados no URBAN5, vista (esq.) e passeio pela perspectiva (dir.) (Fonte: NEGROPONTE, 1970, pg. 80 e 79)

O que o software fazia era buscar consistência e equilíbrio entre suas características intrínsecas e suas configurações manipuladas pelo arquiteto, ou seja, “[...] um estado temporário sem conflitos e sem incompatibilidades ${ }^{\prime 74}$. O sistema foi concebido de forma que o aprendizado ocorresse em ambos os sentidos: tanto o arquiteto/usuário aprenderia a utilizá-lo, quanto o próprio sistema aprenderia sobre o arquiteto e suas escolhas na medida em que a interação entre os dois ocorresse. "Assim o URBAN5

\footnotetext{
73 Do original em inglês: Beyond the traits of solid and void, each ten foot cube (whether solid or void) has preallocated receptacles for ten characteristics that refers to aspects of sunlight, outdoor access, visual privacy, acoustical privacy, usability, direct access, climate control, natural light, flexibility, structural feasibility. All these qualities are implicitly ascribed to elements. In other words, without the user's permission, intervention or even awareness, URBAN5 automatically assigns the absence or presence of these features using a predefined geometry for each quality 73 (NEGROPONTE, 1970,p.81).

74 Do original em inglês: (...) a temporary state of no conflicts and no incompatibilities (NEGROPONTE, 1970, p.83).
} 
teria que ensinar sua própria linguagem, aprender por meio do ensino, mudar pelo aprendizado e adaptar pelas mudanças" ${ }^{75}$ (NEGROPONTE, 1970, p.83).

Sem a intenção de resolver problemas específicos, o URBAN5, conforme Negroponte $(1970$, p.83) foi concebido, primordialmente, como um instrumento de pesquisa. A idéia é que "[...] este tipo de interação entre a forma e critérios, arquiteto e máquina, comece a sugerir um diálogo"76. Um tipo de diálogo que poderia elevar as máquinas até a função de arquitetos associados, dentro do processo de design. $O$ autor assim resume suas intenções, daquela época:

Nosso interesse é simplesmente introduzir e incentivar uma inteligência da máquina que estimule um design para uma vida boa e irá permitir um conjunto completo de métodos de autoaperfeiçoamento. Nós estamos falando sobre uma simbiose que é uma coabitação de duas espécies inteligentes ${ }^{77}$ (NEGROPONTE, 1970, p.7).

Pensar o computador como um parceiro do arquiteto na formulação e geração de espaços também fundamentou grande parte do trabalho de Frazer (1995) ${ }^{78}$, em sua busca por uma arquitetura evolutiva. Mais do que a modelagem de formas, a partir de suas aparências, o foco do arquiteto foi sempre o de empregar, na arquitetura, a potencialidade do computador em simular processos naturais. Desta forma, seu trabalho pode ser considerado um dos pioneiros em pensar conceitos arquitetônicos com base em regras generativas, ou seja, a partir de suas lógicas internas.

De uma maneira geral, o trabalho destes arquitetos faz parte de um grupo cujas experimentações marcam a introdução do pensamento computacional, na arquitetura. Por mais que estes trabalhos não tenham feito parte da principal corrente crítica da arquitetura de seu tempo. Como Rocha (2004) explora em seus estudos ${ }^{79}$, a popularização dos computadores, junto ao aumento de sua capacidade de processamento, retoma estas mesmas questões, porém, desta vez, as fazem disponíveis para um público muito maior. Cabe, então, entender como estas idéias

\footnotetext{
75 Do original em inglês: Thus URBAN5 would have to teach its own language; learn through teaching, change from learning, and adapt from changing (NEGROPONTE, 1970, p.83).

76 Do original em inglês: This sort of interplay between form and criteria, architect and machine, begins to suggest a dialogue (NEGROPONTE, 1970, p.83).

77 Do original em inglês: Our interest is simply to preface and to encourage a machine intelligence that stimulates a design for the good life and will allow for a full set of self-improving methods. We are talking about a symbiosis that is a cohabitation of two intelligent species (NEGROPONTE, 1970, p.7).

78 An Evolutionary Architecture é o nome do livro no qual Frazer explora projetos e idéias que vem desenvolvendo deste o final da década de 1960 (FRAZER, 1995). São trinta anos de trabalho que ilustram possibilidades e processos de design baseados em técnicas de computação generativas e evolutivas.

${ }^{79}$ Ao fazer a revisão de literatura o autor constata como os principais textos que propõe uma retrospectiva da teoria em arquitetura, deixaram de lado aqueles que possuíam uma influência computacional/matemática, sendo que a maioria das revisões focam sempre no caráter sociológico da arquitetura.
} 
ficaram até, certo ponto pendentes, e o que constitui o atual contexto que permite sua retomada, então como parte da prática cotidiana.

A proximidade dos arquitetos citados e de outros pioneiros com os centros e laboratórios, nos quais os computadores estavam sendo desenvolvidos, permitia que eles vislumbrassem de maneira muito concreta o que ainda estava por vir para a arquitetura. No início desse processo, em meados da década de 1960, os computadores não eram tão acessíveis, o que obrigava as pessoas a entenderem fundamentos básicos da computação e serem sempre muito econômicas nos códigos (não havia abundância de poder computacional), processo, assim, resumido:

Por meio do design e da construção de nossos próprios circuitos lógicos, nós aprendemos a pensar claramente e economicamente no micro-nível das operações lógicas individuais. Toda computação pode ser reduzida a declarações simples tais como 'and' ou 'nor'. Essas, por sua vez, podem ser representadas por portas lógicas que são feitas de silício com eletrônica equivalente ao transistor. Por meio do desenvolvimento das portas lógicas em elementos computacionais é possível formar qualquer função lógica. Novamente, paralelos podem ser enxergado entre os modelos generativos da natureza e a maneira na qual a aparente complexidade da computação, tanto no hardware quanto no software, são construídos hierarquicamente a partir das mais simples funções ${ }^{80}$ (FRAZER, 1995, p.23).

De forma similar, para Negroponte (1970), a experimentação do computador - como um parceiro de projeto com o qual o arquiteto poderia se engajar em diálogos construtivos - era apenas uma dentre as várias possibilidades de aplicação dos procedimentos computacionais no processo de design. $\mathrm{O}$ arquiteto já entendia que o contínuo desenvolvimento da representação gráfica abria caminho para a geração de perspectivas mais complexas, sendo que chegava a mencionar, inclusive, a utilização de holografias para aumentar o grau de imersão nestas imagens.

Um outro potencial destacado era sua utilização na geração de opções de formas, dentre as quais o arquiteto poderia utilizar sua intuição para filtrar as soluções mais adequadas. Frente a estas informações, o poder computacional poderia ser também utilizado para simulação de eventos e contextos, tanto para o entendimento de

\footnotetext{
80 Do original em inglês: By designing and building our own logic circuits, we learned to think clearly and economically at the micro-level of individual logical operations. All computation can be reduced to simple logical statements such as 'and' or 'nor'. These in turn can be represented by logic gates which are made in silicon out of transistor-equivalent electronics. By building up the logic gates into computational elements it is possible to form any logical function. Again parallels can be seen between the generative methods of nature and the way in which the apparent complexity of computing, in both hardware and software, is built up hierarchically from the simplest functions (FRAZER, 1995, p.23).
} 
problemas quanto para teste e observação de performances. Igualmente importante seria sua aplicação para a catalogação, recuperação e associação de dados relevantes para projetos, cada dia mais complexos.

Nesta descrição temporal, foram as gerações mais evoluídas dos softwares computer aided design - CAD (design assistido pelo computador) que assinalaram, definitivamente, a introdução da computação na prática da arquitetura. O termo é utilizado para denominar uma ampla gama de ferramentas digitais que utilizam métodos sistemáticos normalmente para desenhos, mas também para resolução de problemas lógicos, ligados à diversas etapas e necessidades dos processos de design. 0 resultado de sua associação com as tecnologias digitais de produção e fabricação (computer aided manufactoring - CAM), somados ao crescimento da acessibilidade destes recursos, torna-se cada dia mais evidente na arquitetura.

Eles [CAD e CAM] abriram novas oportunidades por permitirem a produção e construção de formas muito complexas que eram, até recentemente, muito difíceis e caras de serem projetadas, produzidas e montadas usando tecnologias tradicionais de construção. Um novo contínuo digital, uma ligação direta entre o projeto e construção, é estabelecido por meio das tecnologias digitais $^{81}$ (KOLAVERIC, 2003, p.4).

Nesse sentido, Iwamoto (2009) explora a atual relação entre modelos arquitetônicos digitais e artefato físico, construídos por meio das diversas técnicas de produção (CAM) de formas e espaços gerados por softwares (CAD). A autora mostra como funciona a fabricação digital, de que forma os arquitetos têm se apropriado destas possibilidades e como esta técnica viabiliza o design de formas inovadoras. Introduz diversas técnicas que utilizam máquinas comandadas por computadores para cortar e preparar as partes para a construção:

- Sectioning (secionamento, Figura 24): consiste na divisão da forma em inúmeras seções que são produzidas uma a uma e depois reunidas;

- Tessellating (pavimentação, Figura 25-26): subdivisão da superfície em um mosaico de pequenas formas que são posteriormente unidas de maneira contínua;

- Folding (dobraduras, Figura 27-29): utilização de dobras no material para alcançar a forma desejada. Transforma superfícies 2D em 3D;

\footnotetext{
81 Do original em inglês: They [CAD e CAM] opened up new opportunities by allowing production and construction of very complex forms that were, until recently, vey difficult and expensive to design, produce and assemble using traditional construction Technologies. A new digital continuum, a direct link from design to construction, is established through digital technologies (KOLAVERIC, 2003, p.4).
} 
- Contouring (contorno, Figura 30-31): consiste em processo subtrativo da forma. Um bloco de material é escavado por máquinas até a forma desejada ser alcançada;

- Forming (enformação, Figura 32-33): reprodução de formas a partir de moldes (IWAMOTO, 2009).

Fazendo uma retrospectiva, Mitchell (1990) - ao falar sobre a história dos softwares CAD - ressalta a importância do computador pessoal, na década de 1980, para sua difusão. Se, por um lado, esta disseminação em massa popularizou a ferramenta, por outro, forçou sua simplificação por parte de seus desenvolvedores. Altamente sofisticados para as máquinas pessoais da época, muitas funções e habilidades foram omitidas para que estes softwares funcionassem nas máquinas pessoais e, também, para minimizarem a necessidade de assistência técnica para sua instalação. Segundo o autor,

0 efeito negativo na quarta geração do CAD foi estabelecer uma concepção banal e simplista das funções do CAD e dos estilos de interação na mente de muitos arquitetos. Os sistemas CAD foram então vistos, pela maioria dos profissionais e professores de arquitetura, como o equivalente gráfico dos processadores textuais - dispositivos bastante simples para a entrada, edição e produção de documentos gráficos (em vez de textos) ${ }^{82}$ (MITCHELL, 1990, p. 483).

A riqueza perdida a que o autor faz alusão, quando ressalta a simplificação destes softwares refere-se, por um lado, à implementação de funções, atalhos préprogramados que simplificam os processos computacionais por trás das ações, e tiram do usuário, a necessidade de contato com os fundamentos das operações computacionais. Por outro, remete ao abandono de implementação de características interativas do software, tais como aquelas propostas no URBAN5, no qual o paradigma computacional, em questão, referia-se à perspectiva simbiótica entre homem e computador. Neste caso, o desenho era entendido como um meio de comunicação entre o homem e o computador, duas entidades com características e potencialidades distintas, porém complementares.

\footnotetext{
82 Do original em inglês: The negative effect of fourth generation CAD was to establish a banal and simplistic conception of CAD functions and style of interaction in the minds of many architects. CAD systems were now seen, by most professionals and teachers of architecture, as the graphic equivalent of word processors - rather simple devices for input, editing, and production of graphic (rather than text) documents (MITCHELL, 1990, p. 483).
} 

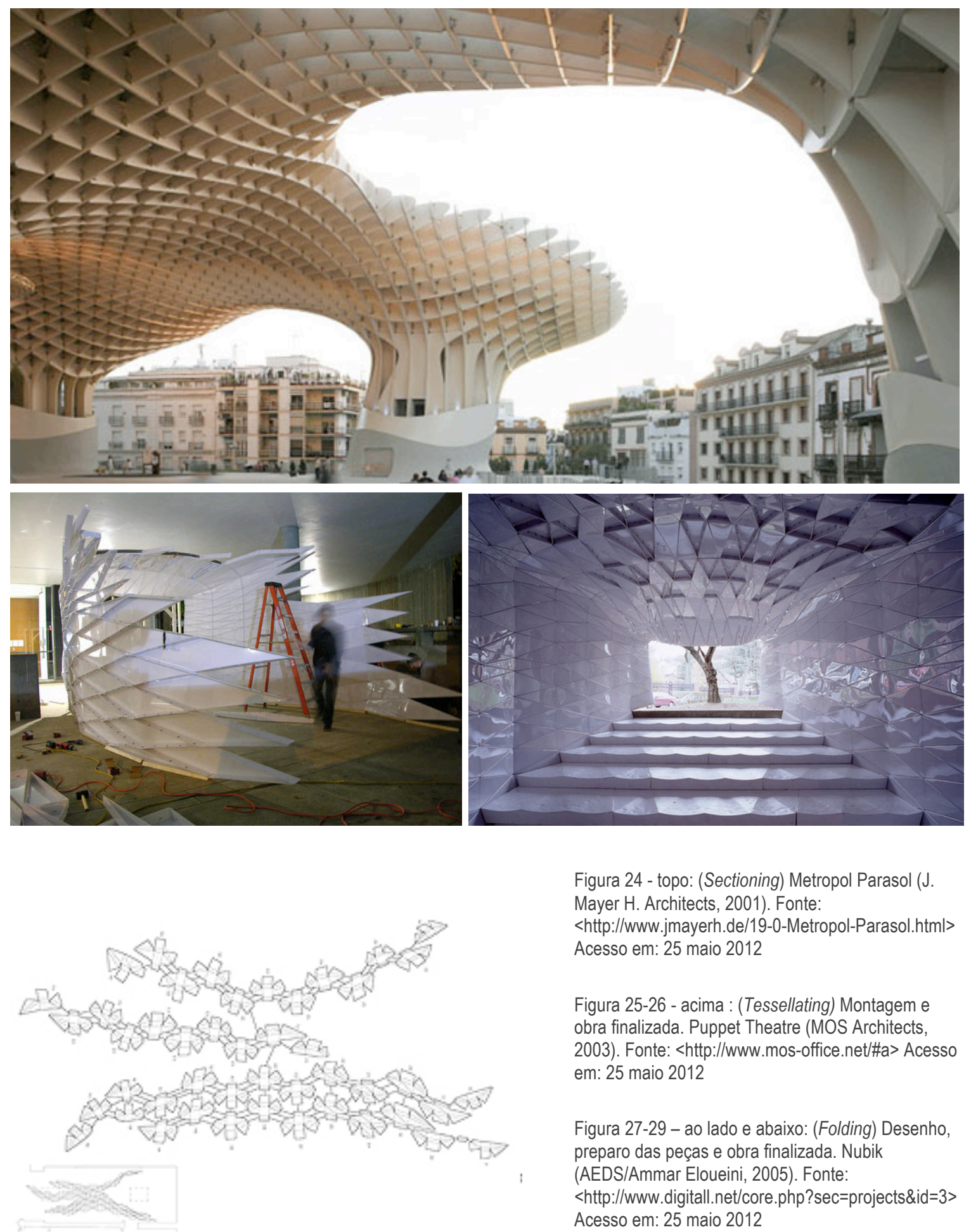

Figura 24 - topo: (Sectioning) Metropol Parasol (J. Mayer H. Architects, 2001). Fonte:

<http://www.jmayerh.de/19-0-Metropol-Parasol.html> Acesso em: 25 maio 2012

Figura 25-26 - acima : (Tessellating) Montagem e obra finalizada. Puppet Theatre (MOS Architects, 2003). Fonte: <http://www.mos-office.net/\#a> Acesso em: 25 maio 2012

Figura 27-29 - ao lado e abaixo: (Folding) Desenho, preparo das peças e obra finalizada. Nubik (AEDS/Ammar Eloueini, 2005). Fonte: <http://www.digitall.net/core.php?sec=projects\&id=3> Acesso em: 25 maio 2012
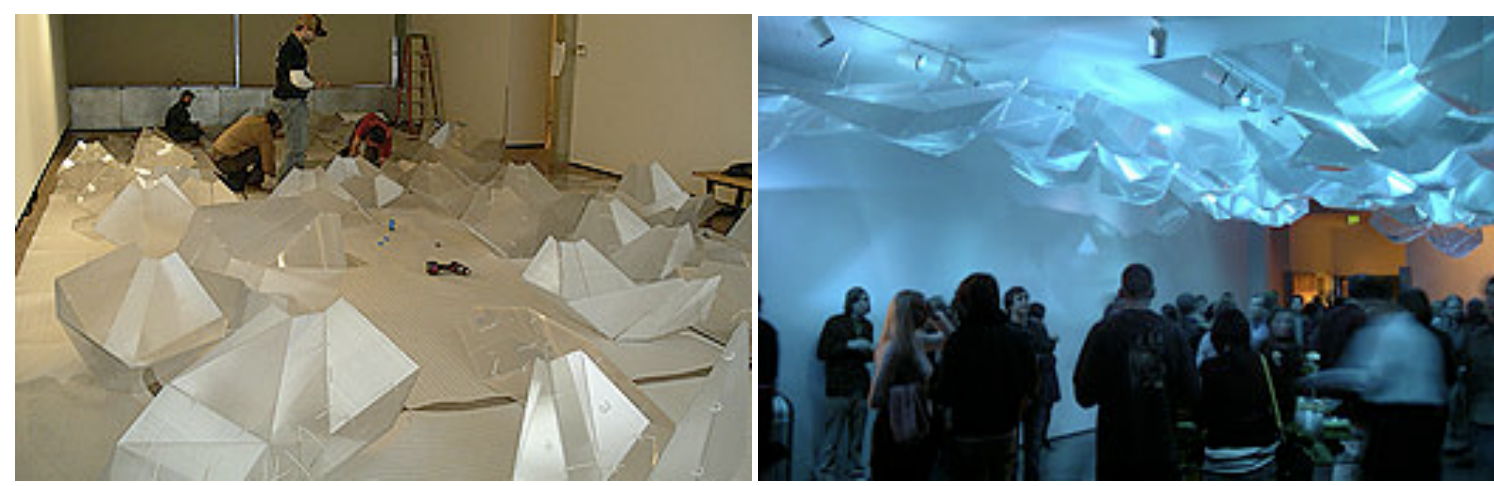

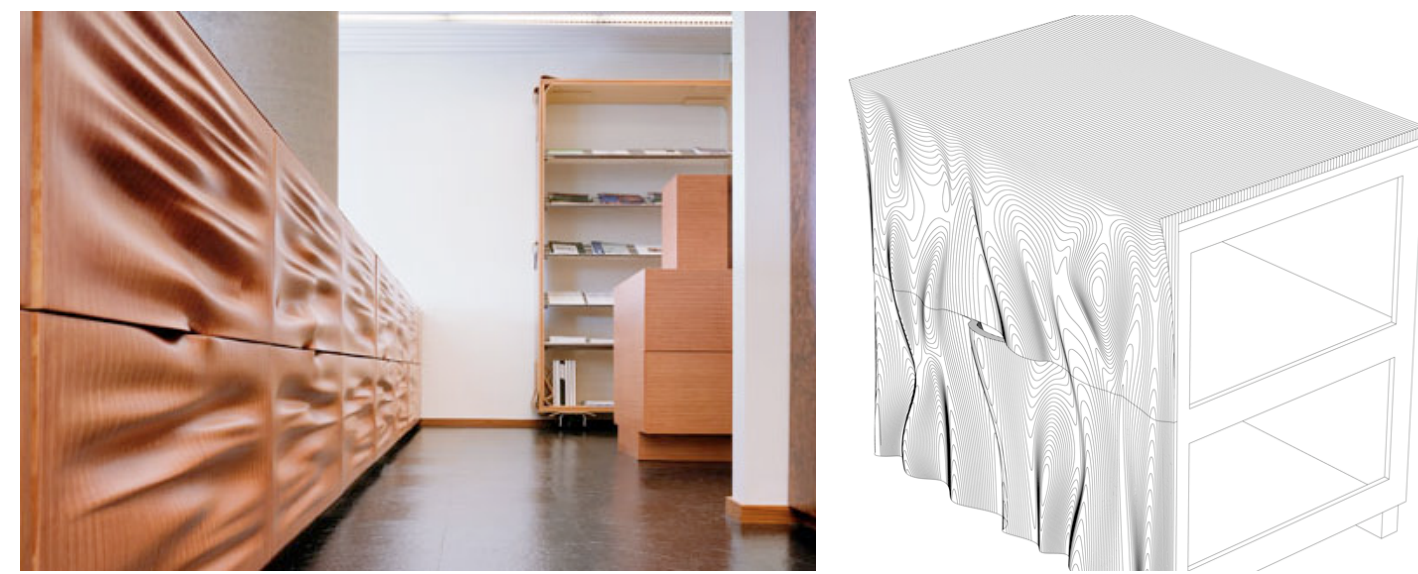

Figura 30-31- acima: (Contouring) Desenho e obra finalizada. Field Files (Williamson Chong Architects);

Fonte: <http://williamsonchong.com/projects/field-files/> Acesso em: 25 maio 2012

Figura 32-33 - abaixo: (Forming ) Fabricação das peças e obra finalizada. Shiatsu ((University of California, Los Angeles/Heather Roberge, 2007)); Fonte: <http://murmur-la.com/shiatsu/> Acesso em: 25 maio 2012
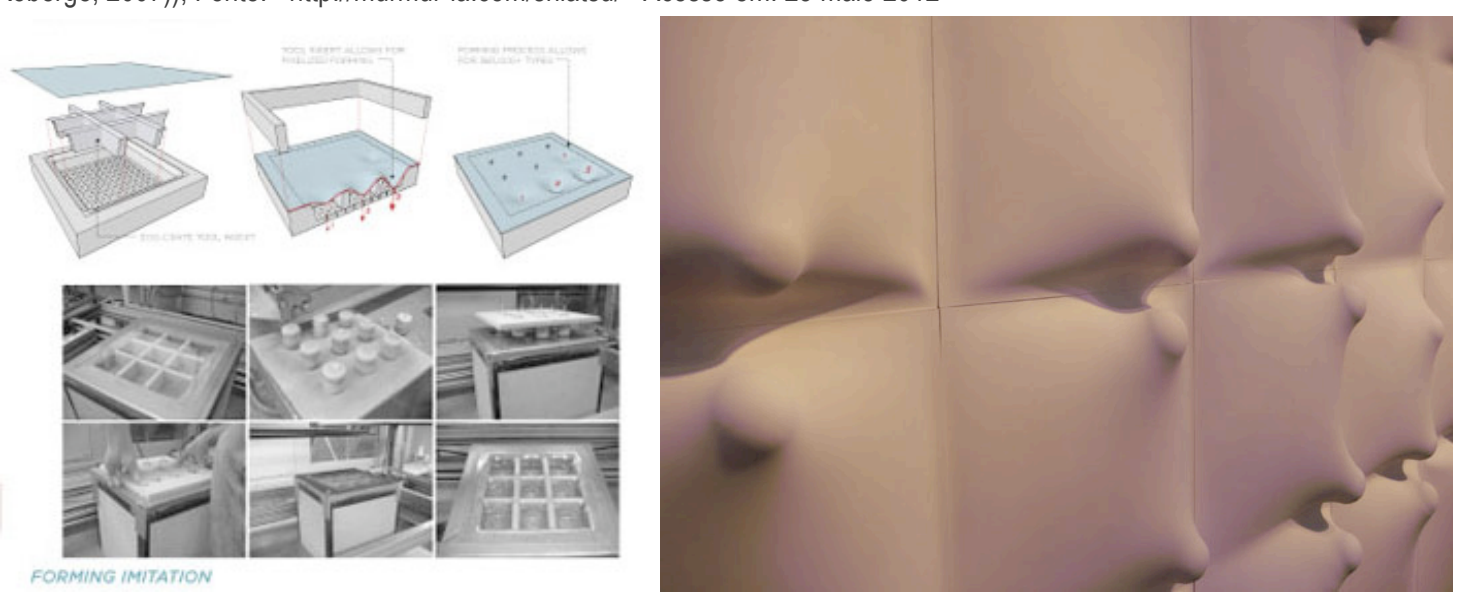

Quase quarenta anos após os experimentos descritos, a idéia de utilização do computador como suporte e ferramenta de representação é, ainda, bastante presente, de maneira que "[...] a maneira dominante de utilização dos computadores hoje na arquitetura é a computerização; entidades ou processos que já estão conceitualizados na mente do designers são introduzidas, manipuladas ou guardadas em um sistema computacional” ${ }^{83} \mathrm{O}$ termo computerization, encontra seu equivalente em português na expressão digitalização, já que se refere ao "[...] ato de introduzir, processar ou guardar informação em um computador [...] trata-se da automação, mecanização, digitalização e conversão" ${ }^{84}$ (TERDIZIS, 2003, p. 96).

83 Do original em inglês: [...] the dominant mode of utilising computers in architecture today is that of computerisation; entities or processes that are already conceptualisedin the designer's mind are entered, manipulated or stored in a computer system (TERDIZIS, 2003, p. 96).

84 Do original em inglês: [...] act of entering, processing or storing information in a computer. [...] It's about automation, mechanisation, digitisation and conversion (TERDIZIS, 2003, p. 96). 
Segundo o autor, a inclusão de linguagens interpretadas (linguagens de script) ${ }^{85}$, nas interfaces dos programas de modelagem tridimensional, foi um importante aspecto que contribuiu para difundir a utilização de algoritmos na geração de formas e soluções de design. "Ao utilizar as linguagens interpretadas os designers podem ir além do mouse, transcendendo as limitações de fábrica dos atuais softwares tridimensionais" ${ }^{\prime 86}$ (TERDIZIS, 2003, p.97). Estas linguagens permitem que o usuário crie pequenos programas dentro do aplicativo, ou seja, procedimentos computacionais para a execução de funções já existentes no software. Assim, no lugar de apenas clicar nos ícones ou chamar as funções por meio dos atalhos, o usuário cria lógicas para sua execução, de forma que processos iterativos e interativos passam a ser possíveis de serem implementados.

A utilização destas linguagens altera o processo de design, já que, neste caso, o “[...] design não está apenas na seleção de critérios, está também na modelagem dos próprios argumentos, tanto de maneira técnica computacional quanto por um viés teórico, material e arquitetônico" ${ }^{87}$ (AHLQUIST; MENDES, 2011, p.28). Mais do que os softwares de modelagem, a principal ferramenta do designer passa a ser o algoritmo, assim definido:

Um algoritmo é um procedimento computacional para abordar um problema por meio de um número finito de passos. Ele envolve dedução, indução, abstração, generalização e lógica estruturada. É uma extração sistemática de princípios lógicos e um desenvolvimento de um plano genérico de solução. Estratégias algorítmicas utilizam a busca por padrões repetitivos, princípios universais, módulos intercambiáveis e capacidades indutivas. 0 poder intelectual de um algoritmo encontra-se na sua habilidade de inferir novos conhecimentos e de estender alguns limites do intelecto humano ${ }^{88}$ (TERDIZIS, 2003, p. 94).

Neste sentido, o pensamento computacional traz uma série de conceitos que são hoje básicos para aqueles que utilizam o computador como ferramenta criativa e, necessários, para aqueles que querem entender este tipo de produção. Dentre estes

850 software Maya foi um dos primeiros a implementar esta função por meio da MEL (Maya Emdedded Language). Hoje diversos outros softwares já disponibilizam este recurso.

86 Do original em inglês: By using scripting languages designers can go beyond the mouse, transcending the factory-set limitations of current three dimensional-software (TERDIZIS, 2003, p.97).

87 Do original em inglês: [...] design is not only in the selection of criteria, but it is in the fashioning of the arguments themselves, in both a technical computational manner and a theoretical, material and architectural vein (AHLQUIST; MENDES, 2011, p.28).

88 Do original em inglês: An algorithm is a computational procedure for addressing a problem in a finite number of steps. It envolves deduction, induction, abstraction, generalisation and structured logic. It is the systematic extraction of logical principles and the development of a generic solution plan. Algorithmic strategies utilise the search for repetitive patterns, universal principles, interchangeable modules and inductive skills. The intellectual power of an algorithm lies in its ability to infer new knowledge and to extend certain limits of the huma intellect (TERDIZIS, 2003, p. 94). 
conceitos, as idéias relacionadas ao pensamento sistêmico, às dependências paramétricas, à morfogênese generativa, às populações evolutivas e formações emergentes passam a ser, a cada dia, mais presentes e relevantes. Segundo Ahlquist e Mendes (2011, p.15):

A introdução da teoria sistêmica na arquitetura e o consequente foco no pensamento sistêmico no design provocaram uma mudança dupla. Primeiramente, a mudança significou a destituição da visão da arquitetura como constituída de entidades estáticas isoladas por uma que define a forma como a culminação de sistemas que interagem com seu contexto por meio de um engajamento material, físico e pessoal. Segundo, esta mudança no pensamento arquitetônico introduziu conceitos fundamentais de como a computação de tais sistemas baseados no comportamento interrelacional e complexo poderia ser alcançado. ${ }^{89}$

De certo modo, esse entendimento sistêmico compõe a base sobre a qual os outros conceitos mencionados se desdobram. Os experimentos, com formações emergentes, caracterizam-se pela atribuição de regras simples para as partes de um sistema e pela observação de características emergentes que a interação entre estas partes podem apresentar. Em outras palavras, “[...] emergência é um processo pelo qual fenômenos complexos surgem da interação de condições simples, nas quais as possibilidades de tais comportamentos complexos não podem ser identificadas nas declarações individuais iniciais" ${ }^{90}$ (AHLQUIST; MENDES, 2011, p. 121).

A partir de raciocínios similares, a interrelação entre partes e a definição de regras matemáticas associativas para a investigação e representação de formas fundamentam o design paramétrico, método cuja popularidade vem aumentando entre arquitetos e designers, assim definido por Ahlquist e Mendes (2011, p.19):

Paramétrico deve ser entendido, convencionalmente, como relacionado apenas às interdependências de certos condicionamentos geométricos. Mas, seu entendimento mais profundo é aquele de estabelecer métodos para interrelacionar comportamentos de formas e forças específicas, e como elas

\footnotetext{
${ }^{89}$ Do original em inglês: The introduction of system theory in architecture and the consequential focus on system thinking in design applied a twofold shift. First, the shift signified a dismissal of the view of architecture as comprised of entities in static isolation for one which defines form as the culmination of systems which Interact with its context in matter, physicality and personal engagement. Second this shift in architectural thinking introduced fundamental concepts for how the computation of such interrelational, complex behavior-based systems could be achieved (AHLQUIST; MENDES, 2011, p.15).

90 Do original em inglês: [...] emergence is a process by which complex phenomena arise from the interaction of simple conditions, where the possibilities of such complex behaviors cannot be identified within the individual initial assertions (AHLQUIST; MENDES, 2011, p. 121).
} 
devem ser representadas como regras associativas matemáticas e geométricas. ${ }^{91}$

Segundo Burry (2003, p.151), implementar este tipo de aproximação requer uma cautelosa reconfiguração da maneira como o problema é abordado, cabendo ao designer a avaliação dos casos nos quais a parametrização seria apropriada. "Se o processo pelo qual um design é produzido é repensado para tirar vantagem do software, defender seu uso pode ser autorealizável se os resultados obtidos ostensivamente justificarem os meios ${ }^{\prime 2}$. Esta adaptação do processo a qual Burry faz referência, trata-se justamente do tempo e esforço necessário para o desenvolvimento dos algoritmos apropriados para cada caso. "Existe, portanto, um balanço cuidadoso necessário entre avaliar qual circunstância do design se beneficiará de ser modelado e retrabalhado posteriormente via a rota de apagar-redesenhar, e qual se beneficiará de um modelo paramétrico totalmente definido." ${ }^{\prime 93}$

A interação entre as partes e como o sistema se desenvolve, ao longo de suas iterações, constitui a base de outro conceito, a morfogênese generativa. Neste caso, “[...] no lugar de modelar uma forma externa, os designers articulam uma lógica generativa interna, a qual depois produz, de modo automático, uma gama de possibilidades da qual o designer poderia escolher uma proposição formal apropriada para continuidade de desenvolvimento" ${ }^{94}$ (KOLAVERIC, 2003, p.4). As explorações mais aprofundadas destas possibilidades, incluem, também, conceitos matemáticos mais complexos, tais como aqueles ligados as geometrias topológicas e polisuperfícies isomórficas (blobs).

Outro conceito importante é o de populações evolutivas, o qual utiliza princípios e teorias biológicas de evolução de espécies para gerar soluções otimizadas de design. 0 grande poder de processamento e visualização gráfica dos computadores atuais permitem a modelagem de diversas teorias evolutivas. $\mathrm{Na}$ arquitetura, os

91 Do original em inglês: Parametrics might be understood, conventionally, as regarding solely the interdependencies of certain geometrical contraints. But, its deeper understanding is that of establishing methods for interrelating particular behaviors of forms and forces, and how they might be represented as associated mathematical and geometric rules (AHLQUIST; MENDES, 2011, p. 19).

92 Do original em inglês: If the process by which a design is produced is rethought to take advantage of the software, defending its use can be self-fulfilling if the results obtained ostensibly justify the means(BURRY, 2003, p. 151).

93 Do original em inglês: There is, therefore, a careful balance required between assessing which design circumstance benefits from being modeled and reworked subsequently via the erasure-redraw route, and which benefits from a fully defined parametric model(BURRY, 2003, p. 151).

94 Do original em inglês: No lugar de modelar uma forma externa, os designers articulam uma lógica generativa interna, a qual depois produz, de modo automático, uma gama de possibilidades da qual o designer poderia escolher uma proposição formal apropriada para continuidade de desenvolvimento (KOLAVERIC, 2003, p.4). 
experimentos realizados for Frazer (1995, p.65) ilustram claramente o processo que permeia esta abordagem. Segundo este arquiteto,

O modelo evolucionário requer que um conceito arquitetural seja descrito na forma de um 'código genético'. Esse código é mutado e desenvolvido por um programa computacional em um série de modelos em resposta a um ambiente simulado. Os modelos são, então, avaliados naquele ambiente e o código dos modelos mais bem sucedidos usados para reiterar o ciclo até que um estágio específico de desenvolvimento é selecionado para prototipagem no mundo real. ${ }^{95}$

Juntamente com os experimentos e discursos mencionados, no início deste tópico, todas estas idéias configuram parte do fundamento das atuais discussões, sobre a inserção da computação no processo de design que permeia a criação arquitetônica. Em contraste, esta pesquisa preocupa-se com uma parte específica, ainda não tratada diretamente, que é a introdução de aspectos computacionais no espaço construído, ou seja, no produto final destes processos. Porém, a relação do objeto principal de estudo com o conteúdo das discussões apresentadas acima, é muito estreita, o que justifica a necessidade da abordagem aqui tratada.

São duas as principais razões pelas quais o contexto delineado interessa para esta pesquisa. Em primeiro lugar, estes experimentos vêm forçando arquitetos e designers, em geral, a se aproximarem de conceitos e procedimentos computacionais. E todo este discurso está, intrinsecamente, ligado com comportamentos que podem ser implementados em espaços interativos.

Em segundo lugar, a inspiração buscada nas estruturas dinâmicas encontradas, no mundo natural e a possibilidade de simulação destes comportamentos formais muito contribuem para a elaboração de estruturas interativas, ou seja, aquelas que apresentam um comportamento dinâmico também quando construídas. Assim, todo o discurso formal apresentado relaciona-se, diretamente, com a estrutura física do espaço e como aspectos dinâmicos podem ser adicionados à ela. Se esta é a porta de entrada, o próximo passo é explorar a fundamentação específica do objeto investigado por esta pesquisa, ou seja, o discurso que permeia, especificamente, a arquitetura enquanto sistema interativo.

\footnotetext{
95 Do original em inglês: The evolutionary model requires and architectural concept to be described in a form of 'genetic code'. This code is mutated and developed by computer program into a series of models in response to a simulated environment. The models are then evaluated in that environment and the code of successful models used to reiterate the cycle until a particular stage of development is selected for prototyping in the real world (FRAZER, 1995, p. 65).
} 


\subsubsection{Produto}

Elaborados os principais aspectos da inserção da tecnologia digital nos processos de design, cabe então, aordar o objeto específico de investigação desta pesquisa, a arquitetura interativa. Trata-se da inserção dos aspectos computacionais no espaço físico, também denominada por Bier e Knight (2010, p.1), como digitally-driven architecture, uma perspectiva na qual,

O foco não é tanto em sistemas baseados em computadores para o desenvolvimento de projetos arquitetônicos, mas na arquitetura que incorpora o controle digital, sensoriamento, atuação, ou outros mecanismos que possibilitam os edifícios interagirem com seus usuários e contextos em tempo real no mundo real por meio da mudança e variação física e sensorial.

O pensamento computacional adentrou o discurso da arquitetura, por meio dos processos de design, sendo que seu maior impacto pode ser, atualmente observado, como já mencionado, na viabilização da concepção e construção de formas que extrapolam a simetria e ortogonalidade. Se este foi o viés pelo qual a computação foi adicionada ao processo, o início de sua incorporação no espaço físico construído deuse por uma perspectiva, basicamente, pragmática, ou seja, aquelas "[...] preocupadas em solucionar necessidades e otimizar soluções", sendo que "[...] as implicações gerais de utilização de tais sistemas na arquitetura incluem, mas não estão limitadas a: eficiência do espaço, abrigo, proteção, transporte, segurança e, é claro, economia" ${ }^{96}$ (FOX; KEMP, 2011, p.30).

Neste sentido, Fox e Kemp (2011, p.58) traçam um panorama histórico da adoção da computação embarcada - do inglês embedded computation - pela arquitetura, "[...] um sistema que é literalmente incorporado no edifício e que tem a habilidade de coletar informação, processá-la, e utilizá-la para controlar o comportamento da arquitetura física em questão" ${ }^{97}$. Segundo os autores, as décadas de 1950 e 1960 foram marcadas pela automação dos diversos sistemas dos edifícios, tais como refrigeração, aquecimento e ventilação, que passaram a ser comandados por controle remotos. Isso se deu, em especial, para simplificar o controle dos grandes edifícios coorporativos que estavam sendo construídos na época.

96 Do original em inglês: Pragmatic applications, which have previously been described, are concerned with solving needs and optimizing solutions. the general implications of utilizing such systems in architecture include, but are not limited to: space efficiency, shelter, security, transportation, safety, and, of course, economics (FOX; KEMP, p.30).

97 Do original em inglês: Embedded computation (EC), in the context of interactive architecture, is a system that is literally embedded into the building and that has the ability to gather information, process it, and use it to control the behavior of the actual physical architecture (FOX; KEMP, p.58). 
Na década de 1970, a computação passou também a ser vislumbrada como meio de implementar um gerenciamento mais eficiente de recursos, por meio do controle do edifício. Nas décadas de 1980 e 1990, com a disseminação dos computadores pessoais e da internet, a potencialidade desta automação expandiu, significativamente, por meio da introdução de aspectos de inteligência (casas inteligentes) e conexão em rede dos dispositivos.

O contexto acima é mencionado para ilustrar como a tecnologia digital foi, desde cedo, incorporada ao espaço físico. Falar da inserção de aspectos computacionais no espaço poderia, então, ser considerado como algo já amplamente abordado e resolvido por estes sistemas. Contudo, é importante assinalar que, apesar dos aspectos mencionados estarem ligados à arquitetura, estes deixam de lado grande parte de sua essência. Conforto e economia de recursos são questões de extrema importância durante a criação do espaço físico, entretanto, a importância do trabalho do arquiteto reside em sua integração, em conjunto com a manipulação dos aspectos sociais e simbólicos do espaço, ou seja, como determinada arquitetura impacta as pessoas tanto individualmente quanto socialmente, e tanto física quanto psicologicamente.

Partindo do pressuposto de que a arquitetura vai além da otimização espacial e funcional, esta pesquisa busca fundamentar um discurso mais humano e social de incorporação dos aspectos computacionais, no espaço construído. Este entendimento pode ser encontrado, por exemplo, nos escritos de Negroponte que, já em 1975, apontava - com base em suas experimentações com softwares e pela observação do contexto tecnológico e social de sua época - que “[...] pela primeira vez na história, por exemplo, nós podemos enxergar a possibilidade de morar em um ambiente feito pelo homem que responde e é 'significante' para ele ou ela"98 (NEGROPONTE, 1975, n.p.). O autor fala a partir de uma época, na qual a tecnologia já estava presente nos edifícios, por meio da automação de seus sistemas, porém seu olhar ia além:

Até que ponto isso vai ou pode ir está aberto a discussão, mas a verdade é que o conceito de um ambiente fisicamente responsivo está passando de sonho à realidade pela força, apropriadamente, das próprias condições ambientais. Estamos fazendo edifícios mais responsivos aos contextos, e ao fazê-los, não se deve esquecer que o contexto final de resposta de um edifício são as necessidades e os sentidos de seus habitantes. Ambientes

\footnotetext{
98 Do original em inglês: [...] for the first time in history, for example, we can see the possibility of everybody having the opportunity to live in a man-made environment that responds to and is meaningful for him or her (NEGROPONTE, 1975, prefácio sp).
} 
"inteligentes", responsivos a você e a mim e ao mundo exterior, podem muito bem acontecer. Ambientes responsivos em um nível funcional massivo já existe. ${ }^{99}$ (NEGROPONTE, 1975, p. 129)

A partir das tecnologias existentes em sua época, o arquiteto propõe cenários que questionam os modelos adotados naquele tempo. Ao invés de fazer analogias do espaço com termostatos e cápsulas espaciais, propõe-se a encarar a arquitetura interativa como se a casa fosse o novo membro da família, capaz inclusive de entender piadas, provida de inteligência, propósito e consciência de seu contexto, e não apenas dotada de controles regulatórios. Segundo Negroponte (1975) por mais que esses cenários possam parecer assustadores, pior seria abster-se de questionar sobre as possibilidades, e deixar que o desenvolvimento puramente técnico tome conta deste campo. É nesse sentido que seu trabalho muito pode contribuir para a visualização de possibilidades deste tipo de prática.

De maneira similar, Frazer (1995), ao se inspirar nas características da natureza para elaborar seu modelo teórico de uma arquitetura evolutiva, visualiza também sua aplicação nos espaços construídos. Além das questões teóricas colocadas, outro aspecto interessante de seu trabalho é a criação de artefatos computacionais integrados ao desenvolvimento do código.

Neste sentido, vale destacar alguns experimentos mencionados por Frazer (1995), realizados no início da década de 1980, com modelagem física inteligente - do inglês intelligent physical models - nos quais se criavam, por exemplo, sistemas de módulos físicos dotados de circuitos eletrônicos capazes de reconhecerem sua posição em relação aos outros (Figura 34-35). Essa informação, de como os módulos estavam conectados, era, então, interpretada pelo computador e formas gráficas eram geradas.

A definição dessas formas variava. Elas poderiam representar a geometria montada como os módulos tal como ela era, ou os módulos poderiam ser apenas o ponto de entrada para a manipulação de formas geométricas mais complexas na tela. Segundo este arquiteto, "[...] apesar de ainda serem muito limitados a kit-de-peças, forneciam uma alternativa viável aos mouses, teclados ou digitalizadores" ${ }^{100}$ (FRAZER, 1995, p.39).

\footnotetext{
99 Do original em inglês: How far this will or can go is opne to argument but the fact ramains that the concept of a physically responsive environment is being turned from dream to reality by the force, appropriately enough, of environmental circumstances themselves. We are making buildings more context responsive, and in doing so we should not forget that a building's final context of esponse is the needs and senses of its inhabitants (NEGROPONTE, 1975, p. 129).

100 Do original em inglês: Although still severely limited to a kit-of-parts, it provided a viable alternative to mouse, keyboard or digitizer input100 (FRAZER, 1995, p.39).
} 

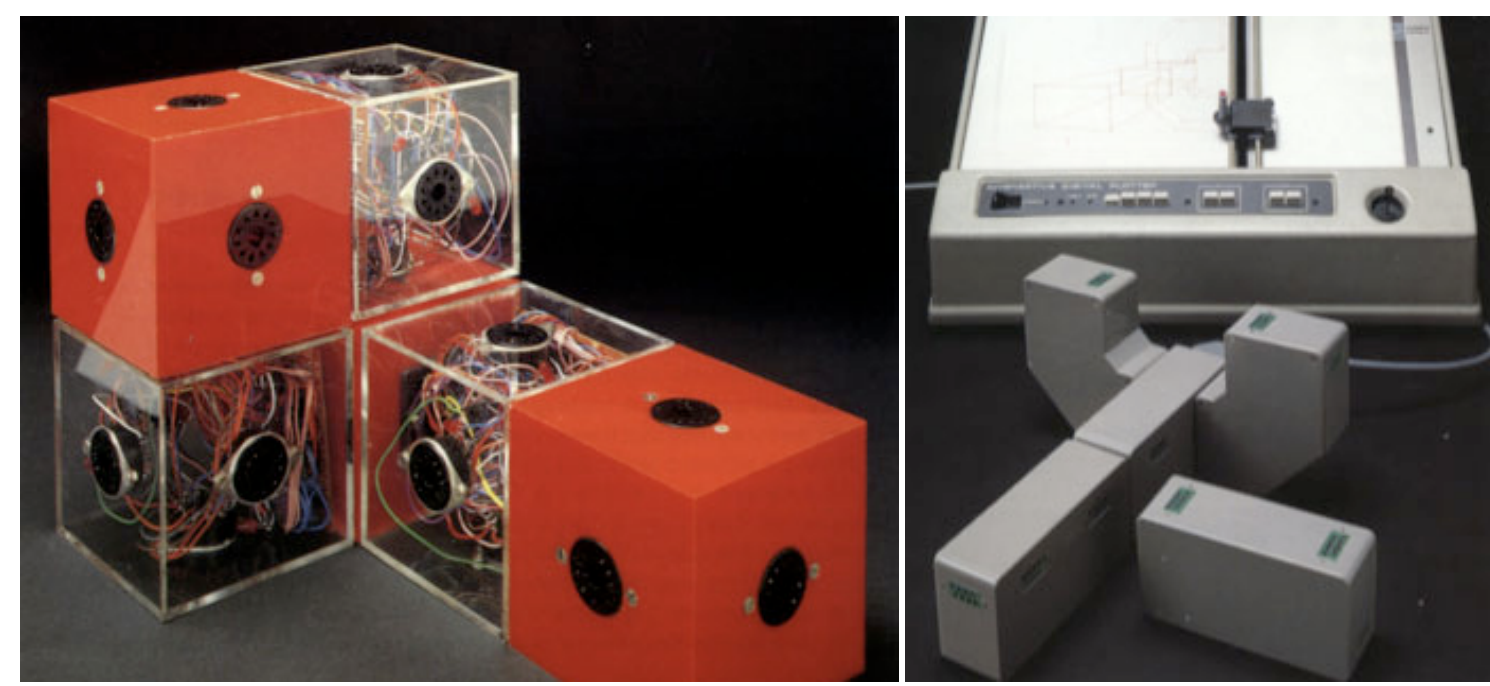

Figura 34-35: Modelos físicos inteligenste de Frazer. As formas montadas com as peças poderiam ser interpretadas ou reproduzidas com fidelidade (Fonte: FRAZER, 1995, p. 38-39)

Foram estas experimentações que levaram Frazer a ser convidado para colaborar no projeto Generator (1978, Figura 36), do arquiteto inglês Cedric Price, "[...] um dos primeiros arquitetos a usar as tecnologias de informação para criar e arquitetar variações responsivas da forma e do uso" ${ }^{\prime 101}$ (MATHEWS, 2007, p.242). O projeto é assim descrito por Frazer (1995, p.40):

Tratava-se de um kit de peças que permitiu que cercas, passarelas, telas e serviços fossem organizados e reorganizados para atender os requisitos variáveis do cliente. (...) Foi proposta a divisão do local (uma clareira em uma floresta na Flórida), com blocos de fundação e o fornecimento de um guindaste móvel permanente para mover os componentes, permitindo que os usuários do edifício se envolvessem na sua organização. ${ }^{102}$

Nesse projeto, John e Julia Frazer (FRAZER, 1995, p.40) atuaram como colaboradores nos aspectos relacionados à computação de seu comportamento. Introduziram eletrônica em todos os componentes do espaço, conectando-os, por meio dos blocos da fundação e transformando o lugar "[...] em um grande modelo operante - um processador gigante de matriz reconfigurável" ${ }^{103}$. O comportamento elaborado por eles previa que, quando o espaço passasse muito tempo sem ser alterado pelos usuários, talvez por não perceberem que a possibilidade de reconfiguração existisse, ficaria entediado e faria mudanças por ele mesmo. Segundo o arquiteto,

\footnotetext{
101 Do original em inglês: Price became one of the first architects to use information technology to create and architecture responsive to variability of form and use(MATHEWS, 2007, p.242).

102 Do original em inglês: This consisted of a kit of parts which enabled enclosures, gangways, screens and services to be arranged and re-arranged to meet the changing requirements of the client. [...] It was proposed to grid the site (a clearing in a forest in Florida) with foundation pads and to provide a permanent mobile crane for moving components, allowing the users of the building to become involved in its organization (FRAZER, 1995, p.40).

103 Do original em inglês: into a vast working model - a gigantic reconfigurable array processor (FRAZER, 1995, p. 40).
} 


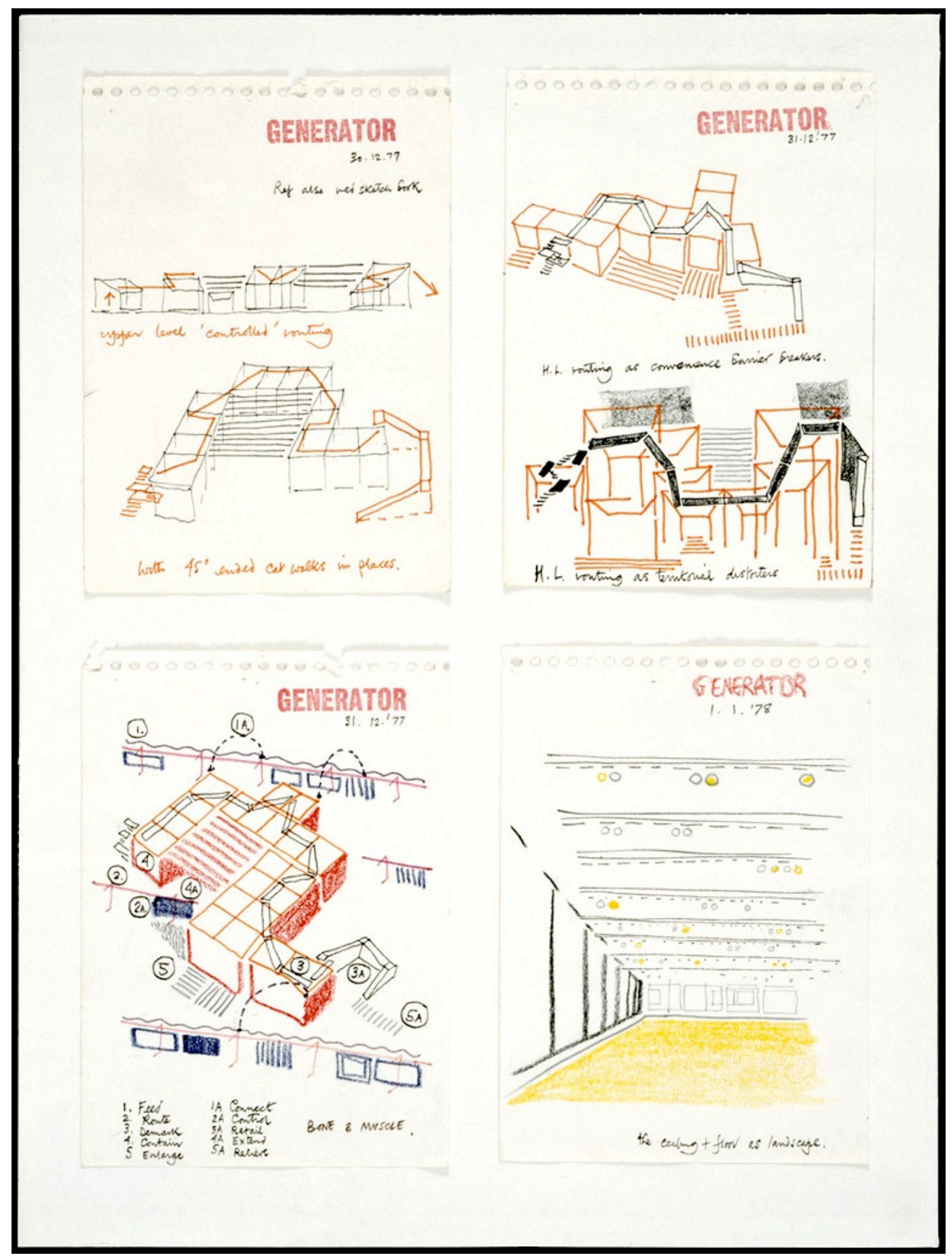

Figura 36: Esboços do projeto Generator (Cedric Price, 1978) (Fonte: <http://www.mobiletest.moma.org> Acesso em: 10 fev. 2014)

"[...] Isso não é tão engraçado quanto parece, já que nossa intenção era que o Generator aprendesse com as alterações que fazia na sua própria organização, e treinasse a si mesmo a fazer melhores sugestões. No final o próprio edifício seria mais capaz de determinar sua configuração para o benefício dos usuários, do que os próprios usuários"104 (FRAZER, 1995, p.41).

104 Do original em inglês: This is not as facetious as it may sond, as we intended the Generator to learn from the alterations it made to its own organization, and coach itself to make better suggestions. Ultimalety the building 
Cedric Price, da mesma forma que outros arquitetos e artistas, tais como Archigram, Yona Friedman e John Cage nutriram suas idéias, durante a época pós-II guerra britânica, caracterizada por um espírito otimista e libertário, bem como pela rápida mudança dos valores tradicionais. Segundo Matthews (2007, p.242), “[...] 1960s em Londres era um tempo ideal da inocência, impagável otimismo e possibilidades infinitas, quando tudo o que era sólido no império britânico tinha derretido no ar" ${ }^{105}$. Apesar de participar do mesmo contexto e de exercer uma influência significativa junto aos colegas, Price nunca se identificou com nenhum grupo ou corrente de pensamento específico da época, e seu trabalho foi caracterizado pelo questionamento do papel da arquitetura e do arquiteto como um todo. Para ele, a arquitetura era uma reflexão efêmera das transformações, pelas quais a sociedade e a cultura são constantemente submetidas.

Neste sentido, sua essência encontra-se no processo ao invés da forma, e o papel do arquiteto "[...] não era construir monumentos eternos, mas simplesmente fornecer ambientes de moradias fáceis e adaptáveis para o presente e futuro imediato"106 (MATHEWS, 2007, p.30). Ao elaborar novos conceitos, sua intenção era redefinir as maneiras que a arquitetura e o arquiteto poderiam atuar, no aprimoramento do potencial humano e, assim, promover mudanças sociais. Quando entrou em contato com os sistemas e processos relacionados à tecnologia digital, viu neles, o meio ideal para introduzir as alternativas dinâmicas que já vinha vislumbrando, no ambiente humano.

Embora ele não fosse o único arquiteto nos anos do pós-guerra a desenvolver um interesse por computadores e outras tecnologias emergentes, a sua aplicação de novas tecnologias era única. Em nítido contraste com o Archigram e o arquitetos de High-Tech, cujo uso da tecnologia permaneceu em grande parte uma questão do imaginário simbólico e estético, Price tornou os computadores partes integrantes de seus projetos. No entanto, ele nunca viu a tecnologia como um fim em si mesmo. (...) Seu objetivo era explorar novos meios para habilitar a arquitetura a se adaptar às necessidades de mudança da sociedade e, esperançosamente, também melhorar a qualidade de vida107 (MATHEWS, 2007, p.242).

itself might be better able to determine its arrangement for the users' benefit than the users themselves (FRAZER, 1995, p. 41)..

105 Do original em inglês: 1960s London was an ideal time of innocence, unbilled optimism and endless possibility, when all that was solid in the British Empire had melted in the air (MATHEWS, 2007, p.242).

106 Do original em inglês: Price developed a conviction that the responsibility of the architect was not to build eternal monuments, but simply to provide easily and adaptable living environments for the present and immediate future (MATHEWS, 2007, p.30).

107 Do original em inglês: Although he was not the only architect in the post-war years to develop an interest in computers and other emerging technologies, his application of new technologies was unique. In sharp contrast to 
Além do Generator, é cada dia mais recorrente a referência às idéias contidas em dois outros projetos de Price, cuja influência na arquitetura posterior é marcante, apesar de não terem sido construídos, o Fun Palace e o Potteries Thinkbelt. O Fun Palace (1961, Figura 37) foi criado em parceria com a atriz e diretora teatral Joan Littlewood, a partir de uma crítica profunda ao sistema educacional tradicional da Inglaterra. É considerado um experimento social em diversas dimensões pois incorporava novas maneiras de construir, ser e pensar.

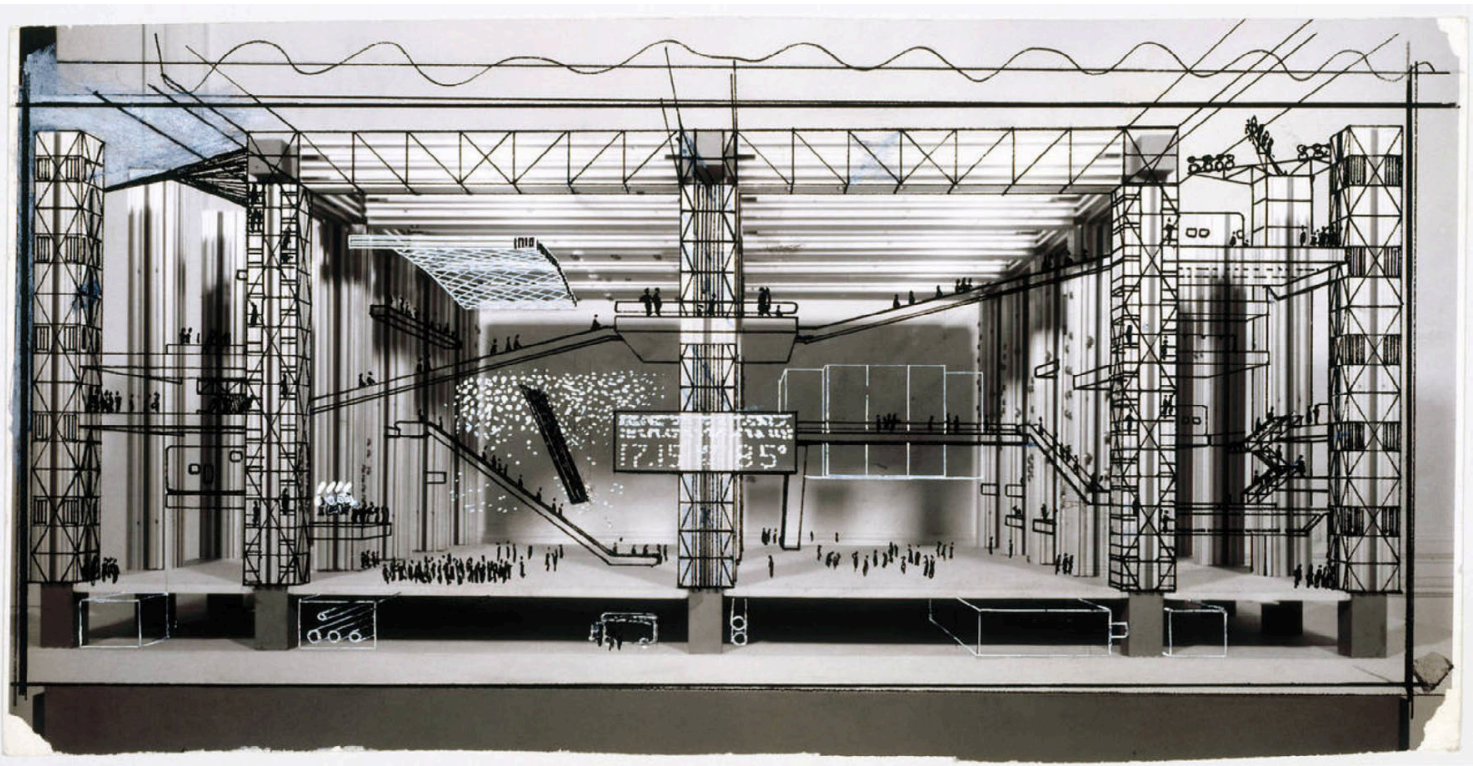

Figura 37: Perspectiva do Fun Palace (Price, 1961) (Fonte: <sllsslls.com/blog/fun-palace> Acesso em 9 Fev. 2014)

Price, ao propor esse projeto, desafiou a definição de arquitetura pois não se tratava de um edifício em sua forma tradicional e, sim, "[...] uma matriz que abrigava uma máquina interativa, uma arquitetura virtual que fundia arte e tecnologia” ${ }^{108}$. Fruto de uma crença, que hoje pode parecer até inocente, no potencial transformador da tecnologia, seu programa assemelhava-se mais com um programa de computador do que com uma arquitetura tradicional, ou seja, “[...] uma série de funções algorítmicas e portas lógicas que controlam processos temporais em um aparato virtual"109 (MATHEWS, 2007, p. 13-74).

O Potteries Thinkbelt (1965, Figura 38-39) propunha uma arquitetura enquanto serviço para revitalização de um setor industrial em decadência. Tratava-se da recuperação e

Archigram and to High-Tech architects, whose use of technology remained largely a matter of symbolic and aesthetic imagery, Price made computers as integral part of his designs. However, he never saw technology as an end in itself. (...) His goal was to exploit new means to enable architecture to adapt to the changing needs of society and, hopefully, to enhance the quality of life as well107 (MATHEWS, 2007, p.242).

108 Do original em inglês: (...) a matrix that enclosed an intective machine, a virtual architecture merging art and technology (MATHEWS, 2007, p.13).

109 Do original em inglês: (...) an array of algoritmic functions and logical gateways that control temporal processes in a virtual device (MATHEWS, 2007, p. 74). 
conversão de áreas industriais e ferrovias, que se tornariam infraestrutura básica para uma nova escola, um laboratório de idéias, nas quais trabalhadores, desempregados, poderiam estudar sobre ciência e tecnologia.

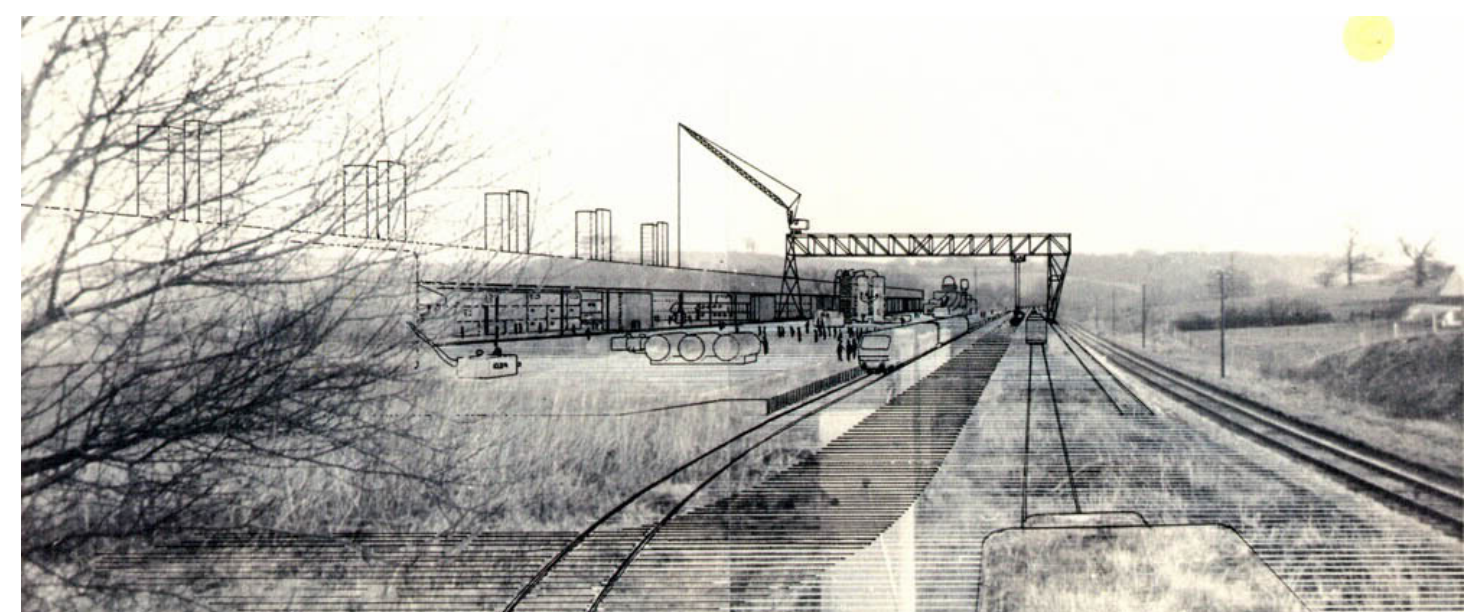

Figura 38: Perspectiva do projeto Potteries Thinkbelt (Cedric Price, 1965)

(Fonte: <http://www.moma.org/collection/object.php?objecto_id=849> Acesso em: 9 Fev. 2014)

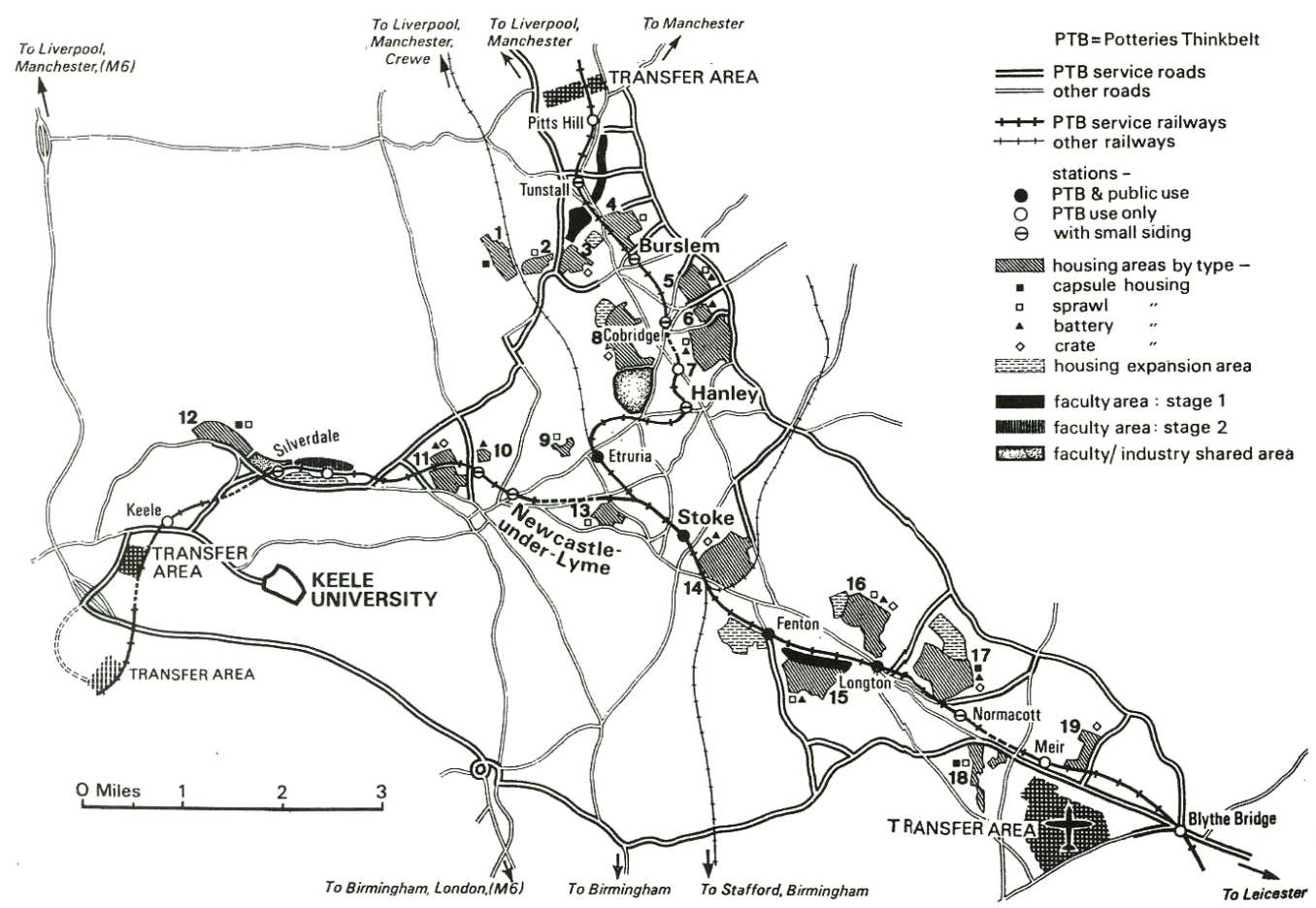

Figura 39: Área de intervenção, com distribuição de usos, do projeto Potteries Thinkbelt (Cedric Price, 1965) (Fonte: <http://www.designmuseum.org/_entry/4696?style=design_image_popup> Acesso em: 9 Fev. 2014)

No cerne desta idéia, estava a intenção de dissolver as barreiras entre ciência pura e aplicada, reverter uma forte emigração de cientistas e pensadores ingleses que estava ocorrendo na época e recolocar a Inglaterra na frente do desenvolvimento das tecnologias de comunicação e informação. Como descreve Mathews (2007, p.13): 
O Fun Palace e o Potteries Thinkbelt não eram edifícios no sentido convencional, mas eram, em vez disso, altamente adaptáveis às mudanças das condições culturais e sociais de seu tempo e lugar. (...) Esses princípios anunciaram um novo paradigma, da arquitetura da escolha, ambigüidade e indeterminação. Os projetos de Price eram situações construídas em que os acontecimentos humanos eram livres para se desenrolar à vontade. 110

O diferencial do pensamento de Price é seu comprometimento com a arquitetura, enquanto instrumento de melhoria social, de forma que a tecnologia, cibernética e teorias afins foram sempre incorporadas como meios e não como objetivos. "Suas motivações foram consistentemente sociais: a emancipação e o empoderamenteo do indivíduo. (...) Ele disse: “Não era sobre tecnologia. Era sobre as pessoas" ${ }^{111}$. Desde então, sua influência pode ser observada em diversos projetos, por exemplo, o Centre Georges Pompidou (1977, Figura 40-41) dos arquitetos Renzo Piano e Richard Rogers, que "[...] tentaram simbolicamente transmitir os mesmos ideais de liberdade e dinâmica expressados no Fun Palace"112 (MATHEWS, 2007, p.189-257).

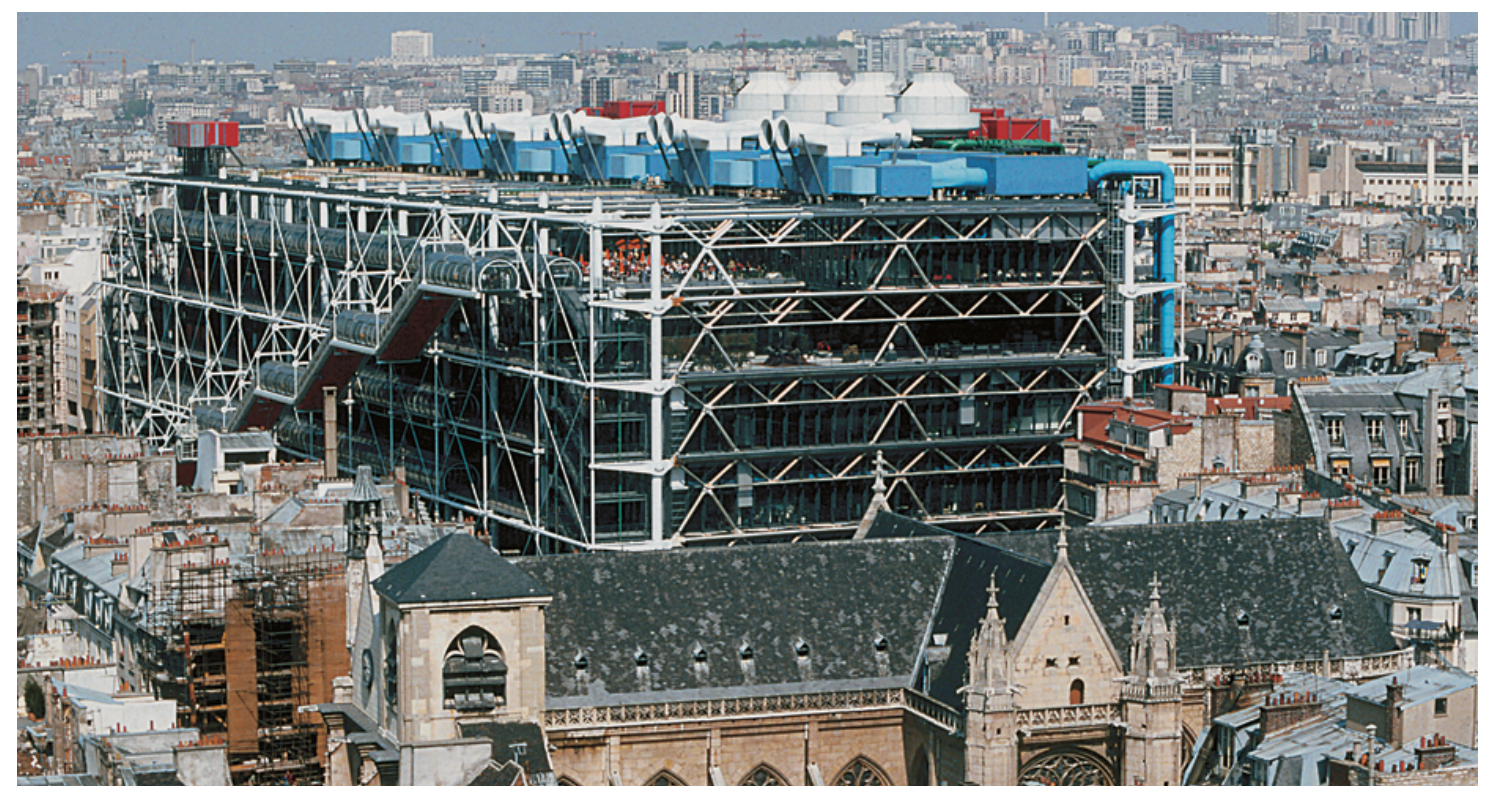

Figura 40: Centre Georges Pompidou (Renzo Piano e Richard Rogers, 1977)

(Fonte: <http://www.phaidon.com/agenda/architecture/picture-galleries/2010/apri//08/renzo-piano-building-workshop/?idx=3> Acesso em: 10 Fev. 2014)

110 Do original em inglês: The Fun Palace and Potteries Thinkbelt were not buildings in any conventional sense, but were instead highly adaptable to the shifting cultural and social conditions of their time and place. [...] These beginnings heralded a new architectural paradigm of choice, ambiguity and indeterminacy. Price's designs were constructed situations within which human events were free to play out at will (MATHEWS, 2007, p.13).

111 Do original em inglês: His motivations was consistently social: the emancipation and the empowerment of the individual. [...] He said: '[It] wasn't about technology. It was about people.' (MATHEWS, 2007, p.257).

112 Do original em inglês: [...] tried to symbollically convey the same ideals of freedom and agency expressed in the Fun Palace (MATHEWS, 2007, p.189). 
Entretanto, quando entram em cena os comprometimentos orçamentários e programáticos que um projeto ideal precisa submeter-se ser construído, muito da teoria e das idéias iniciais, inevitavelmente, perdem-se no processo. A esse respeito, fica sempre a interrogação do que teria realmente acontecido com os projetos de Price, caso tivessem sido feitas as alterações que sua viabilização impunha. É sempre instigante compreender o que acontece com idéias revolucionárias ou inovadoras quando são colocadas em prática e de que maneira ainda são válidas mesmo que reduzidas.

Com o tempo e desenvolvimento tecnológico, esses conceitos passaram a nutrir idéias e projetos passíveis de serem viabilizados. Alguns podem ser considerados icônicos no sentido que ilustram combinações entre possibilidades técnicas e explorações conceituais, manifestando-se no espaço construído. Um exemplo é o Pavilhão da Água Doce, construído em 1997 (Figura 41-43), concebido por Lars Spuybroek e o grupo NOX, ante comissão do governo Holandês.

Junto ao Pavilhão da Água Salgada, projetado por Kas Oosterhuis, o objetivo da FreshH2O Expo era divulgar o projeto de construção de diques para controle do nível da água no país e, ao mesmo, tempo tratar da importância da água e da preservação dos recursos naturais. Segundo Ferrante (2013, p.233), a arquitetura dos pavilhões foi pensada não apenas como abrigo da exposição mas como o próprio objeto expositivo. “O resultado foi uma arquitetura que visava à ativação sensorial do usuário, sua interação com o espaço, utilizando ferramentas interativas digitais e computadorizadas".

A combinação de uma geometria não convencional com possibilidades interativas tecnológicas é o que atribui ao projeto seu caráter inovador. "A geometria fluida e orgânica, tanto internamente quanto externamente, quase, de fato, uma metáfora da maleabilidade e liquidez da água, visa reverter o posicionamento orientado e estável do usuário no espaço e estimular seu movimento". Isso, somado aos diversos tipos de sensoriamento que controlam, ao longo de mais de 60 metros de superfícies contínuas e irregulares, jatos de água, sons e projeções de imagens, faz com que forma e conteúdo constituam, de uma vez só, a experiência desta arquitetura.

O comportamento do pavilhão, é baseado em processos e metáforas sobre a água e influenciado tanto pela movimentação das pessoas no seu interior quanto por parâmetros ambientais, tais como informações sobre o tempo e sobre o nível da água 

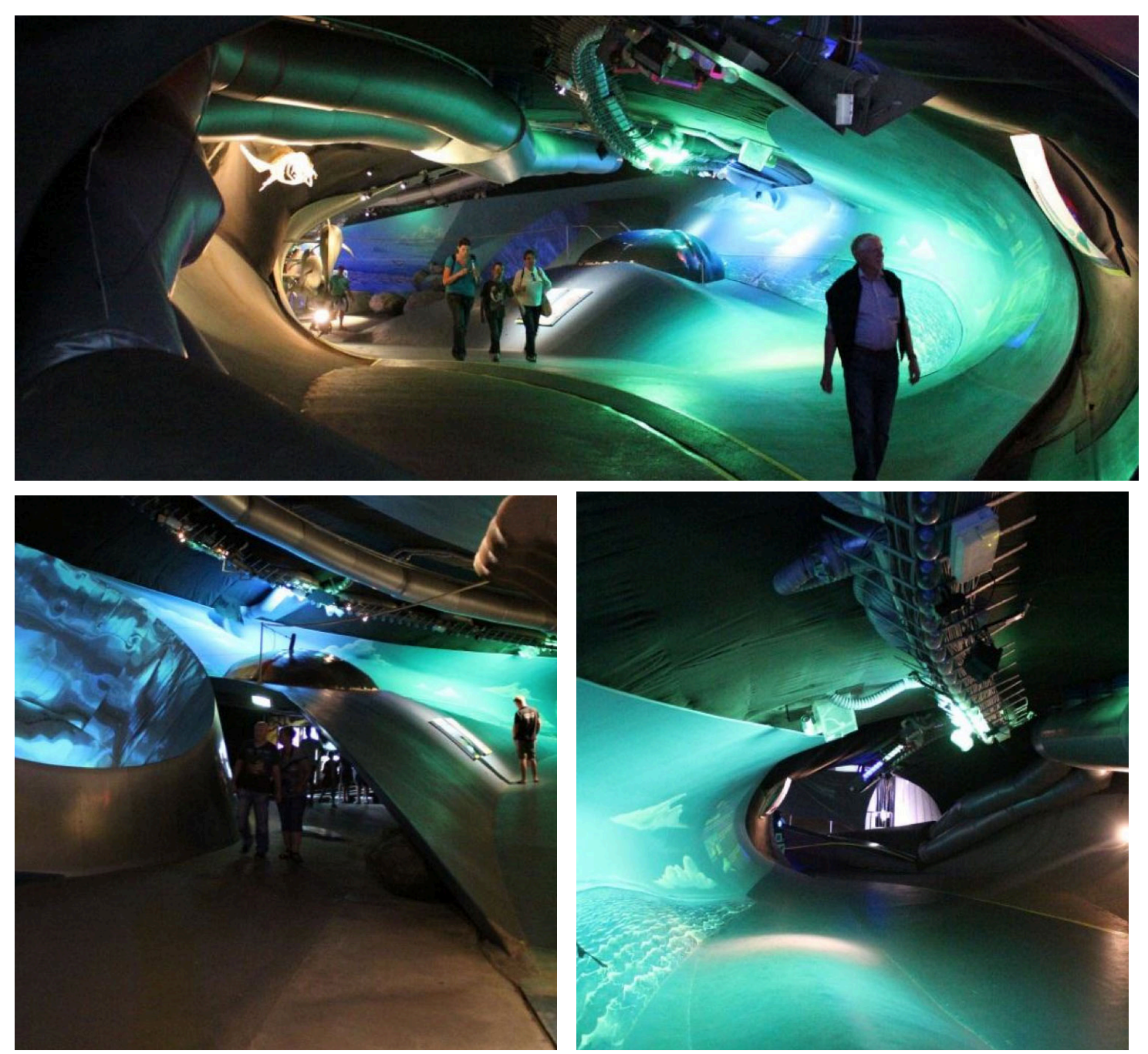

Figura 41-43: Pavilhão da Água Doce, vista interna - arquitetura interativa com superficies contínuas, entre pisos, parede e cobertura (Fonte: cortesia de Isabela Ferrante, 2012)

do mar. Com essa proposta, este espaço é considerado um dos primeiros representantes construídos das frequentes especulações sobre tecnologia, virtualidade, digital, liquidez, que permearam as teorias e críticas arquitetônicas no final do século XX (FERRANTE, 2013, p.233-246).

A Aegis Hyposurface, construída em 1999 (Figura 44-45), ilustra a combinação entre geometria fluida, mecânica e sensoriamento na forma de uma parede interativa. Por mais que não se trate de um exemplo de arquitetura no sentido tradicional, e sim, de um protótipo de $10 \times 3$ metros, representa "[...] os primeiros passos na criação de uma superfície interativa que é capaz de reagir às influências do ambiente" (HAEUSLER, 2009, p. 43). Assim, por materializar uma superfície não regular, e ao mesmo tempo dinâmica - resultado da fusão entre computação e elementos físicos reconfiguráveis - é um exemplo importante que marca uma significativa ampliação do vocabulário arquitetônico. Segundo Haeusler (2009, p.43), 
Ele compreende dois componentes principais, um dispositivo físico - a superfície como tal - e um sistema de controle para controlar a superfície. 0 dispositivo físico é constituído por uma estrutura modular, uma matriz de pistões pneumáticos, e uma superfície física de facetas metálicos bi-polares fraccionados em pequenas placas interligadas por anéis de borracha .(...) 0 sistema de controle é composto por um dispositivo computacional que fornece informações através de um sistema BUS que conecta os pistões. Isto permite que a superfície capte seu ambiente por meio de sensores e, consequentemente, reaja em tempo real, transformando espectadores em participantes ${ }^{113}$ (HAEUSLER, 2009, p. 43).

Com a mesma perspectiva de investigar a relação entre arquitetura e informação, a mídia fachada $B I X$, construída em 2003, é considerada o primeiro projeto no qual a integração da mídia digital em uma superfície arquitetônica foi feita como meio de explorar o significado que este tipo de elemento pode adquirir (HAEUSLER, 2009). Até então, os discursos sobre mídia digital e arquitetura eram ditados por companhias e por seus produtos, que normalmente apresentavam a idéia de que uma boa mídia fachada eram aquelas que transformavam os edifícios em gigantescas telas, utilizadas, principalmente, como letreiros e para veicular propagandas. A maneira como essa integração deveria ocorrer e seu significado não eram, ainda, questões discutidas por

Figura 44-45: AEGIS Hyposurface (dECOI, 1999)

(Fonte: <http://www.hyposurface.org> Acesso em: 10 Fev. 2012)
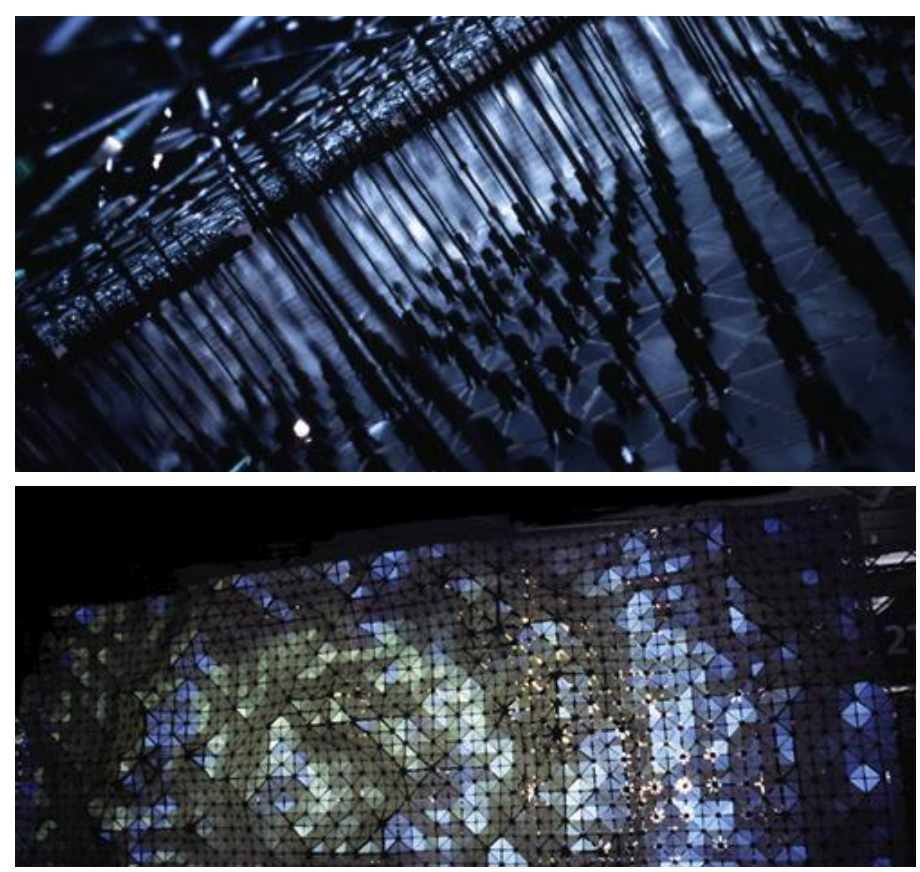

113 Do original em inglês: It comprises two major components a physical device - the surface as such - and a control system to run the surface. The physical device consists of a modular frame, a matrix of pneumatic pistons, and a physical surface of bi-polar metallic facets fractioned into small plates interconnected by rubber squids. [...] The control system comprises a computational device feeding information via a connecting bus system into the pistons. This allows the surface to capture its environment via sensors and consequently to react in real-time, thus making spectators into participants (HAEUSLER, 2009, p. 43). 
arquitetos e, muito menos, pelas empresas. Em entrevista concedida para esta pesquisa, Tim Edler, um dos criadores do sistema BIX comenta: “[...] Nós começamos a pensar sobre isso e não pudemos ignorar que é basicamente uma questão não teorizada" (EDLER, 2011, p.2).

A fachada $B I X$ foi desenvolvida pelo escritório realites:united e integrada ao Kunsthaus Graz (Casa da Arte de Graz), projeto de Peter Cook para a cidade austríaca, em ocasião de seu ano como capital da cultura européia em 2003 (Figura 46). A semelhança entre a forma irregular do museu e algumas propostas do grupo Archigram (Figura 47) não é mera semelhança, já que Cook era um de seus principais membros.

Instalada na fachada do edifício, BIX consiste em um sistema que incorpora 930 lâmpadas florescentes instaladas atrás de painéis de acrílico, controladas por programas e circuitos computacionais, e que abrange uma área de, aproximadamente, 20 por 40 metros. A intensidade de cada lâmpada pode ser controlada individualmente e gera imagens, filmes e animações em baixa resolução, porém avistadas a grandes distâncias. "Devido à baixa resolução, a fachada precisa de conteúdo especificamente produzido. Enquanto isso exclui o uso do conteúdo pré-gravado para a fachada, incentiva o debate sobre conteúdos para locais específicos"114 (HAEUSLER, 2009, p.99).
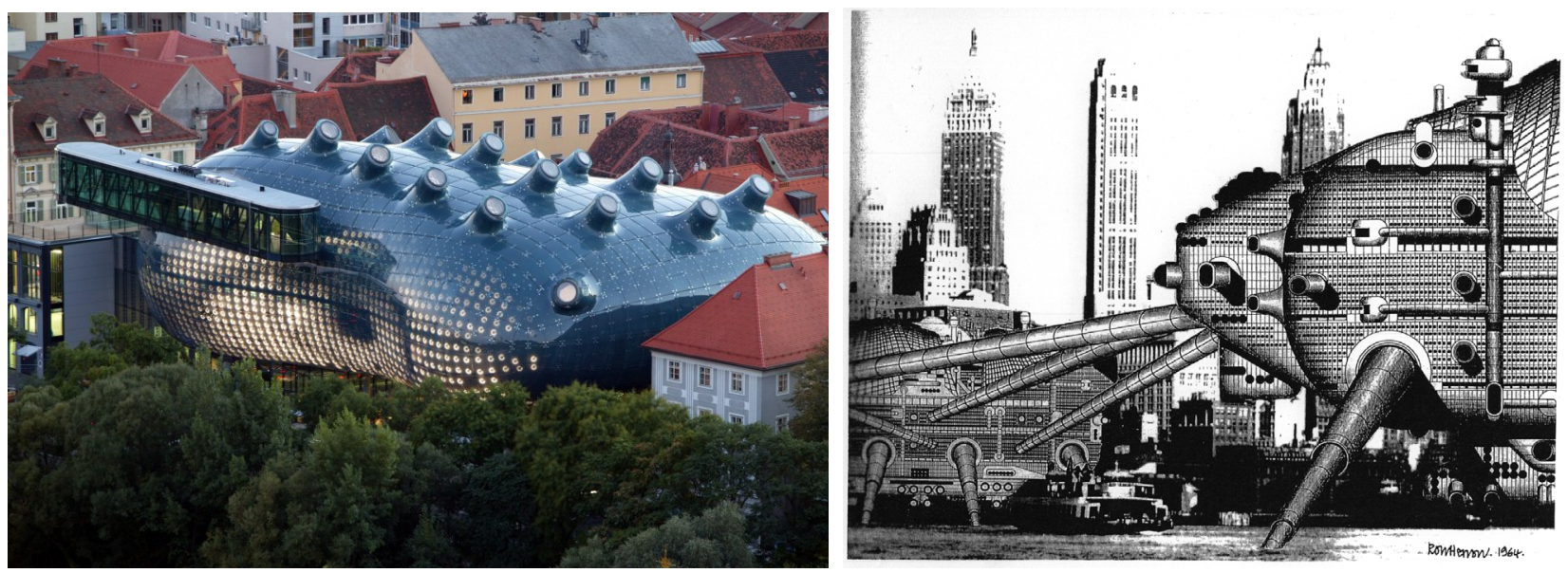

Figura 46 - direita: Museu Kunsthaus Graz (Peter Cook) com a fachada BIX (realites:united)

(Fonte: <http://www.realities-united.de/\#PROJECT,69,3,191_1> Acesso em 10 Fev. 2014)

Figura 47 - esquerda: Desenho do projeto Walking City (Archigram, 1964)

(Fonte: <http://archipressone.files.wordpress.com/2012/09/archigramw.gif> Acesso em 10 Fev. 2014)

Edler (2011), em seus relatos, argumentou sobre o processo de integração do sistema $B I X$ na fachada do edifício, que, segundo sua perspectiva, foi o resultado de uma série

114 Do original em inglês: Due to the low resolution, the facade needs specifically produced content. While this rules out the use of pre-recorded content for the facade, it encourages a debate about site-especific content (HAEUSLER, 2009, p.99). 
de eventos excepcionais. A inserção do realites:united, no projeto, aconteceu por meio de um concurso comissionado, o qual buscava idéias a serem implementadas no museu que discutissem o significado da fusão entre arquitetura, museu de arte e mídia. O material entregue continha vários conceitos que iam, desde a disponibilização de internet por todo o museu, até como o museu seria representado online. Entre eles estava o sistema para a fachada que, na verdade, saía do escopo do que tinha sido requisitado. Para os arquitetos, essa relação mostrou-se fundamental, pois,

[A fachada BIX] era definitivamente a idéia que não se encaixava, de forma alguma, no escopo definido pela comissão. Mas, olhando para a arquitetura, nós percebemos a inabilidade do edifício, que estava se tornando aparente na época, de comunicar-se com o lado de fora. Nós achamos esse, um problema mais fundamental, que equipamentos tecnológicos que se tornariam, de todo jeito, obsoletos depois de quatro anos (EDLER, 2009, n.p.).

A proposta do sistema BIX estava em conformidade com as críticas que o edifício vinha recebendo, na época. Em especial, questionava-se o ao alto custo da fachada em acrílico, sendo que o edifício era, na verdade, opaco. Havia, sim, uma intenção no projeto original que ele fosse, parcialmente, transparente, mas esta se perdeu nas primeiras revisões a que foi submetido, em especial por dificultar o controle de luz necessário para a exposição de obras específicas. Assim, o cruzamento do significado do edifício para a cidade com as potencialidades oferecidas pela mídia digital, e a oportunidade que os arquitetos do realites:united tiveram para apresentar suas idéias foi o que, realmente, fez com que o projeto da fachada acontecesse.

Após isso, foi necessário chegar a uma solução que não solicitasse mudanças de nenhum tipo na estrutura do edifício, de forma que a baixa resolução foi, inicialmente, resultado das restrições do projeto. Edler (2011, n.p.), acerca dessas considerações, observa que: "Nós tínhamos este grande edifício, nós queríamos ter esta coisa gigante, nós tínhamos essas lâmpadas que eram as mais baratas e imagináveis naquele momento". O apoio de uma empresa de iluminação específica que se interessou pelo projeto, por mais que saísse dos padrões usuais, também foi fundamental no processo, já que "[...] pudemos passar para um produto industrial, no lugar de um produto específico baseados em oficinas". Por fim, para entender as possibilidades deste tipo de projeto, a colaboração com um profissional especializado em mídias, o VJ (video jockey) John Dekron, foi essencial, "[...] no final, ele basicamente criou o software que precisávamos para rodar o sistema, e também para fazer ferramentas de simulação e tudo o que você precisa para brincar com o edifício." 

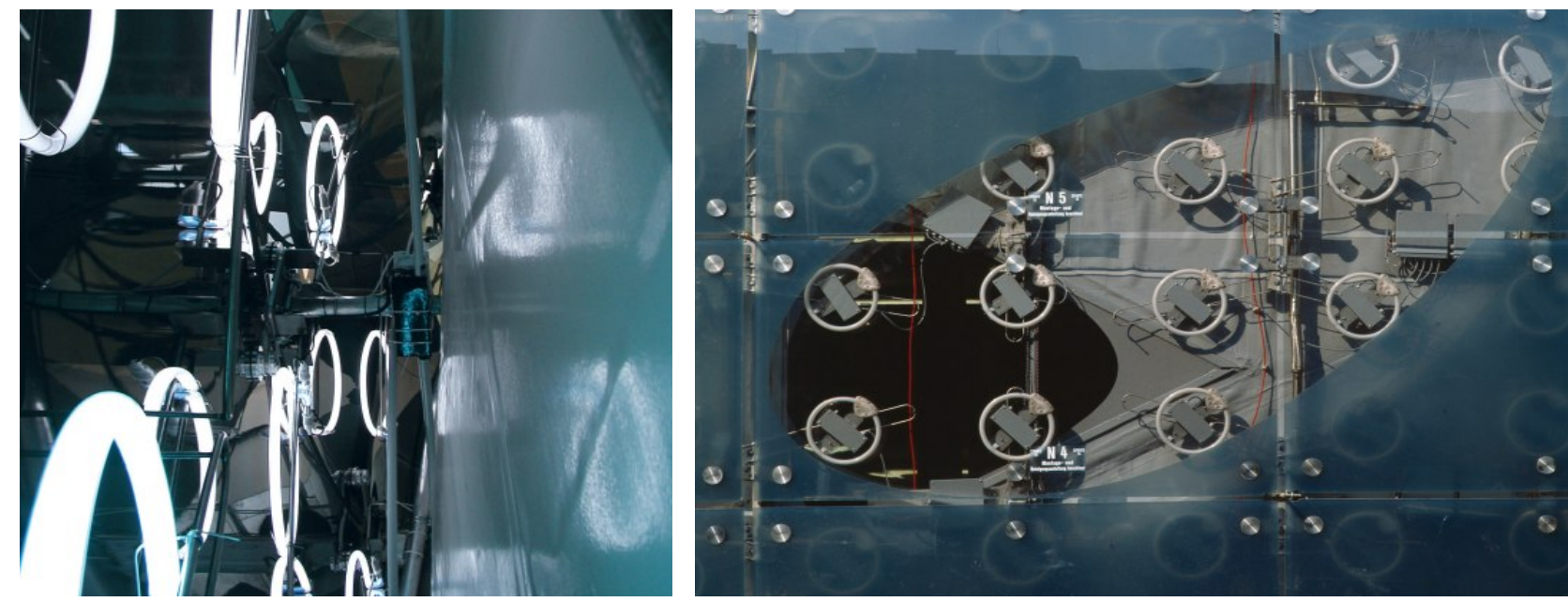

Figura 48-49: Detalhes da fachada BIX - lâmpadas luminescentes (realites:united, 2003)

(Fonte: <http://www.realities-united.de> Acesso em: 10 Fev. 2014)

Após a criação desta fachada, diversas outras se seguiram e o escritório ficou reconhecido como especializado, neste tipo de projeto. Porém, Edler (2011, n.p.) trata de seus projetos, a partir de uma perspectiva bastante crítica e focada na experimentação. Defende que a arquitetura deve absorver a tecnologia não como um showroom, no qual são dispostas todas as novas possibilidades oferecidas pelo mercado e, sim, de forma crítica, criativa e significativa. Quanto a isso, afirma: "[...] tudo o que fazemos agora são realmente experimentos, no quais $90 \%$ da energia investida é para destruir as idéias pré-concebidas sobre mídia fachadas, para basicamente abrir a discussão". Sua postura questionadora é bem acentuada, quando coloca o arquiteto e o designer na posição de criadores do contexto e não como consumidores do que é imposto pelo mercado. Assim, define a posição ocupada por seus projetos na sociedade atual:

Acho que existem muitos aspectos problemáticos [com nossos projetos]. Acho que emitimos muita informação; nem todos os edifícios podem emitir tanta informação. Em segundo lugar existe um desperdício de energia. Em terceiro lugar, vem a poluição luminosa; existem aspectos ambientais sobre animais se tornarem confusos. Existem várias outras coisas. Mas eu acho que ainda somos um pouco ignorantes quanto a isso porque, no momento, ainda não existe o risco que as coisas que fazemos agora tome conta de toda a cidade. 0 perigo maior que vemos é que se não existirem esses experimentos que tentam encontrar o verdadeiro sentido da mídia na arquitetura, em vinte anos quando as mídias fachadas serão tão baratas quanto tintas, o que vai acontecer é que propaganda, outdoors comerciais e projetos interativos banais Irão cobrir toda a cidade. Acho que este é o maior risco (EDLER, 2011, p.8). 
Segundo o arquiteto, essa necessidade de experimentação consciente e questionadora é necessária, pois este tipo de arquitetura, cada dia mais dinâmica, pede novas estratégias de criação. Existe um certo deslumbramento com estas possibilidades e, principalmente, por parte do cliente, ainda se trata de construir edifícios que chamem a atenção e se destaquem no meio dos outros. Neste sentido, é papel do arquiteto desenvolver uma postura sobre o assunto e tomar a responsabilidade para si de participar, como protagonista, no desenvolvimento da tecnologia que insere em seus projetos.

Todos os exemplos descritos ilustram a inserção da tecnologia digital no objeto arquitetônico, além de incorporarem, também, o pensamento computacional no processo. llustram a perspectiva da arquitetura interativa nutrida por este estudo, que aborda da inclusão da tecnologia digital como meio de expressão e não apenas como sistema de automação. Nesse sentido, a arquitetura interativa ultrapassa o entendimento da arquitetura enquanto, simplesmente, elemento da cidade inteligente, tal como descrita por Greenfield (2013).

O resultado almejado, tanto por estas iniciativas quanto pelo objeto de estudo desta pesquisa, é uma arquitetura que se adapta, interage, aprende e evolui com seu contexto, ao mesmo tempo em que expande o discurso determinista e tecnológico. Conceito, simbolismo, forma e tecnologia fundem-se em uma mesma instância e extrapolam o emprego dos meios digitais. Suas propriedades, enquanto meio de expressão, é que são exploradas, de forma que, os exemplos citados ilustram a apropriação criativa dos recursos técnicos nos produtos arquitetônicos. Para ser capaz de analisar e criar este tipo de arquitetura é necessário entender o que ela tem de específico. Para isso, dois aspectos intrinsecamente complementares serão abordados, sua estrutura e seu comportamento.

\subsection{Estrutura}

Ao longo da história, a arquitetura vem apropriando-se dos diversos tipos de materiais e produtos do desenvolvimento tecnológico da sociedade. Diferentes níveis de leveza, resistência e textura fazem parte de um conjunto de características exploradas pelos engenheiros, arquitetos e designers, quando da definição dos materiais a serem utilizados em uma determinada construção. Com o desenvolvimento dos materiais inteligentes a partir da década de 1990, um novo contexto de processo de criação e produto coloca-se à frente dos arquitetos e designers. Como aponta Coelho (2008, p.13), 
"Mais recentemente, materiais que exibem propriedades eletromecânicas estão preparando o caminho para a total integração de sensores e atuadores no ambiente, expandindo os limites de onde a computação pode ser encontrada e remodelando as maneiras nas quais nós interagimos e comunicamos"115.

Com a utilização destes materiais, a dinâmica e responsividade da arquitetura relaciona-se, não tanto com a movimentação física de seus elementos, mas sim, com a alteração de propriedades dos materiais que a compõe, por meio de estímulos programáveis.

O entendimento da estrutura destes espaços, ou seja, quais são os elementos físicos que o compõe, é aqui esboçado por duas perspectivas. Uma examina a relação entre a arquitetura interativa e a cinética, ou seja, a implementação da interatividade por meio do movimento controlado de seus elementos; a outra, parte da questão da evolução dos materiais e sua implicação na composição dos espaços interativos. Esta divisão é elaborada apenas com o intuito de organizar o entendimento deste tipo de estrutura: enquanto a perspectiva cinética relaciona-se com questões de robótica e biônica, a perspectiva dos materiais pressupõe um outro tipo de embasamento, relacionado com a alteração de suas propriedades físicas, tal como forma, cor, temperatura etc.

\subsubsection{Componentes}

Fundamentalmente, o que viabiliza a construção da arquitetura interativa são os diversos componentes computacionais. Os sensores, atuadores e núcleos processadores, descritos no item 1.2.3, são designações genéricas para um número crescente de elementos, cuja composição e complexidade variam significativamente. Materiais, com diferentes capacidades de condução de energia, são agregados em componentes, cuja utilização combinada permite o controle e a manipulação da corrente elétrica. Acerca deste assunto, vale destacar o que dizem O'Sullivan e Igoe $(2005$, p. 3):

Todos os aparatos elétricos e eletrônicos exploram o fato que os elétrons têm uma tendência a ir de um ponto de maior energia elétrica para um ponto de menor energia elétrica. Você fornece uma conexão positiva (maior energia, ou fonte de alimentação),

115 Do original em inglês: More recently, materials that exhibit electromechanical properties are paving the way for the seamless integration of sensors and actuators into the environment, expanding the limits of where computation can be found and reshaping the ways in which we interact and communicate (COELHO, 2008, p. 13). 
uma conexão negativa (baixa energia, ou terra), e um condutor através do qual os elétrons fluem. Quando você tiver feito isso, os elétrons vão viajar da energia fonte de alimentação para o terra. Ao longo do caminho, você insere vários dispositivos elétricos para desviar os elétrons para fazer que quiser.116

Um circuito elétrico é uma sucessão interligada, um loop fechado, de componentes conectados a uma fonte de energia. Um circuito simples é formado por uma bateria de 3V, um interruptor e um LED. Quando o interruptor é fechado, acende-se a lâmpada. Para entender a lógica do funcionamento dos circuitos elétricos é importante em primeiro lugar, ter em mente que toda energia fornecida pela fonte precisa ser utilizada, ou seja, despendida de alguma maneira. Em segundo lugar, a eletricidade passa sempre pelo caminho, no circuito, que oferece menos resistência a ela (O'SULLIVAN; IGOE, 2005).

Estes são os principais fatores que determinam a escolha de componentes específicos e sua configuração. Caso esses princípios não sejam rigorosamente seguidos, o excedente será sempre convertido em calor pelos componentes, o que pode ocasionar o derretimento de algumas partes, seu mau funcionamento ou mesmo sua deterioração completa. A exclusão de componentes do circuito, por mau funcionamento ou por ligações equivocadas, pode fazer com que a corrente elétrica complete o circuito com uma intensidade muito elevada, o que pode causar curtocircuito que chega a produzir danos irreparáveis, no sistema, ou mesmo reações mais perigosas, como a produção de faíscas ou explosões.

Diversos tipos de materiais podem ser agregados e manipulados, de forma a constituir os componentes computacionais (Figura 50). A principal característica a ser considerada, neste caso, é a propriedade elétrica dos materiais, em especial, sua capacidade de conduzir/resistir às correntes elétricas. Segundo este critério, normalmente são classificados em condutores, semicondutores e não condutores (isolantes ou dielétricos) (ADDINGTON; SHODEK, 2005, p.40).

O resistor, conforme O'Sullivan e Igoe (2005, p.15), é produzido, por exemplo, a partir de um material parcialmente condutor de energia elétrica, tal como o carbono que transforma quantidades específicas de eletricidade em calor. É, normalmente, inserido

\footnotetext{
116 Do original em inglês: All electrical and electronic devices exploit the fact that electrons have a tendency to go from a point of greater electrical energy to a point of lesser electrical energy. You provide a positive connection (greater energy, or power), a negative connection (lower energy, or ground), and a conductor through which the electrons flow. When you've done that, the electrons will travel from power to ground. Along the way, you insert various electrical devices to divert the electrons to do your bidding (O'SULLIVAN; IGOE, 2005,p. 3).
} 
Figura 50: Diversos componentes computacionais, montados em uma placa de prototipagem de circuitos (protoborad).

(Fonte: FOX; KEMP, 2009, p.75)

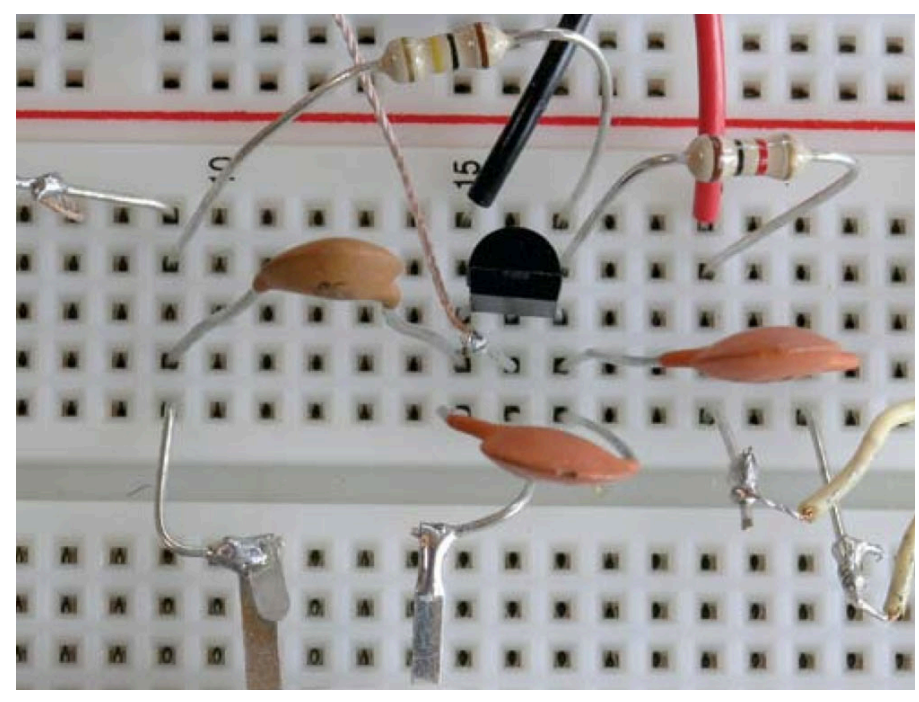

em um circuito para evitar sobrecargas e consequente curtos-circuitos, dissipando o que não será utilizado. Além do resistor produzido com materiais, cujo nível de resistividade é praticamente fixo, existem também alguns semicondutores que variam sua resistência de acordo com estímulos físicos específicos, utilizados em resistores variáveis.

Materiais com resistência variável, são utilizados para a produção de diversos tipos de sensores, ou seja, componentes que transformam energia de diversos tipos em variação elétrica. Um exemplo são os materiais fotoresistivos e termoresistivos que variam a resistência, conforme a intensidade de luz (foto) e calor (termo). Não se trata de uma transformação, mas sim, de um processo de influência: no caso do termistor, o calor altera a resistividade do material. Assim, quando aplicada uma corrente de 5V, dependendo da temperatura, o material permitirá passar uma quantidade de corrente específica.

Um outro componente importante é o diodo que, dependendo de sua composição, exerce diferentes funções em um circuito, sendo que sua principal característica é permitir o fluxo de energia em apenas uma direção. Com isso, é utilizado, por exemplo, para evitar a ligação invertida da fonte e, consequentemente, a queima do circuito, de forma que com uma alimentação invertida o circuito apenas deixa de funcionar. $O$ diodo é, também, utilizado no processo de conversão de correntes elétricas alternadas em contínuas por meio de um processo denominado de retificação. Em sua versão mais conhecida, o diodo emite luz no processo de passagem de energia, configurandose em um potente emissor de luminosidad, de alta durabilidade e baixo consumo energético, também conhecido com o LED (ligh emitting diode). 
Outro tipo de material importante são aqueles com efeito piezoelétrico. Eles podem pertencer a diversos grupos, tais como cristais, polímeros, cerâmicas, entre outros, com a característica comum de produzir pequenas cargas elétricas quando pressionados e vibrar quando estimulados com eletricidade. Por este motivo, pode ser tanto um sensor quanto um atuador, dependendo apenas da forma como é utilizado no circuito. As variações destes materiais são utilizadas, por exemplo, em microfones e caixas de som.

O transistor e o relê são componentes que, em um primeiro momento, atuam como interruptores. Contudo, ao invés de serem acionados com o toque da pessoa, como acontece com um acionador comum de lâmpadas, eles podem ser acionados por sinais elétricos advindos de outros componentes. "Pense neles como pequenos interruptores que ativam interruptores maiores" (O'SULLIVAN; IGOE, 2005, p.18).

A ativação, por meio de pequenas correntes, permite a passagem de correntes maiores, por este motivo, relês e transistores são ainda denominados de amplificadores. Dependendo da estrutura do componente, o inverso também é possível, de tal modo que a ativação por grandes correntes deixa passar correntes menores. Apesar de exercerem funções semelhantes, são diversas as diferenças entre transistores e relês, dentre elas, a quantidade e tipo de corrente elétrica que cada um controla.

Outra grande diferença entre relês e transistores, encontra-se em sua estrutura e forma de funcionamento. O relé é um interruptor eletromecânico, no qual peças se movimentam dentro dele de forma a permitir a passagem de corrente elétrica. Já o resistor, é um elemento que controla a corrente por meio da alteração das propriedades condutoras de seus materiais (semicondutores), sem qualquer movimentação de elementos em seu interior. Os transistores possuem, também, outra função fundamental, quando agrupados de forma adequada eles são utilizados para implementar circuitos lógicos, o que os tornam o componente básico e essencial dos sistemas digitais (VAHID; GIGARVIS, 2002, p.30).

Para Igoe e O'Sullivan (2005), a eletrônica é uma subárea dos circuitos elétricos utilizados para transmitir informações. Neste sentido, é a implementação de raciocínios lógicos, por meio dos circuitos, ou seja, a manipulação de pulsos de energia enquanto informação, que diferencia a elétrica da eletrônica. O circuito integrado é uma tecnologia de produção de circuitos elétricos encapsulados em diferentes 
configurações e dimensões, compostos por milhares e milhões de componentes, em sua maioria transistores, responsáveis por manipular a corrente elétrica, de acordo com os princípios básicos, já mencionados. Com a miniaturização, alguns componentes podem ser considerados pequenos computadores, tal como acontece com os microcontroladores ou mesmo com sensores e atuadores mais avançados que, já, filtram, armazenam e processam a informação captada, facilitando sua conexão com outros computadores (Figura 51).
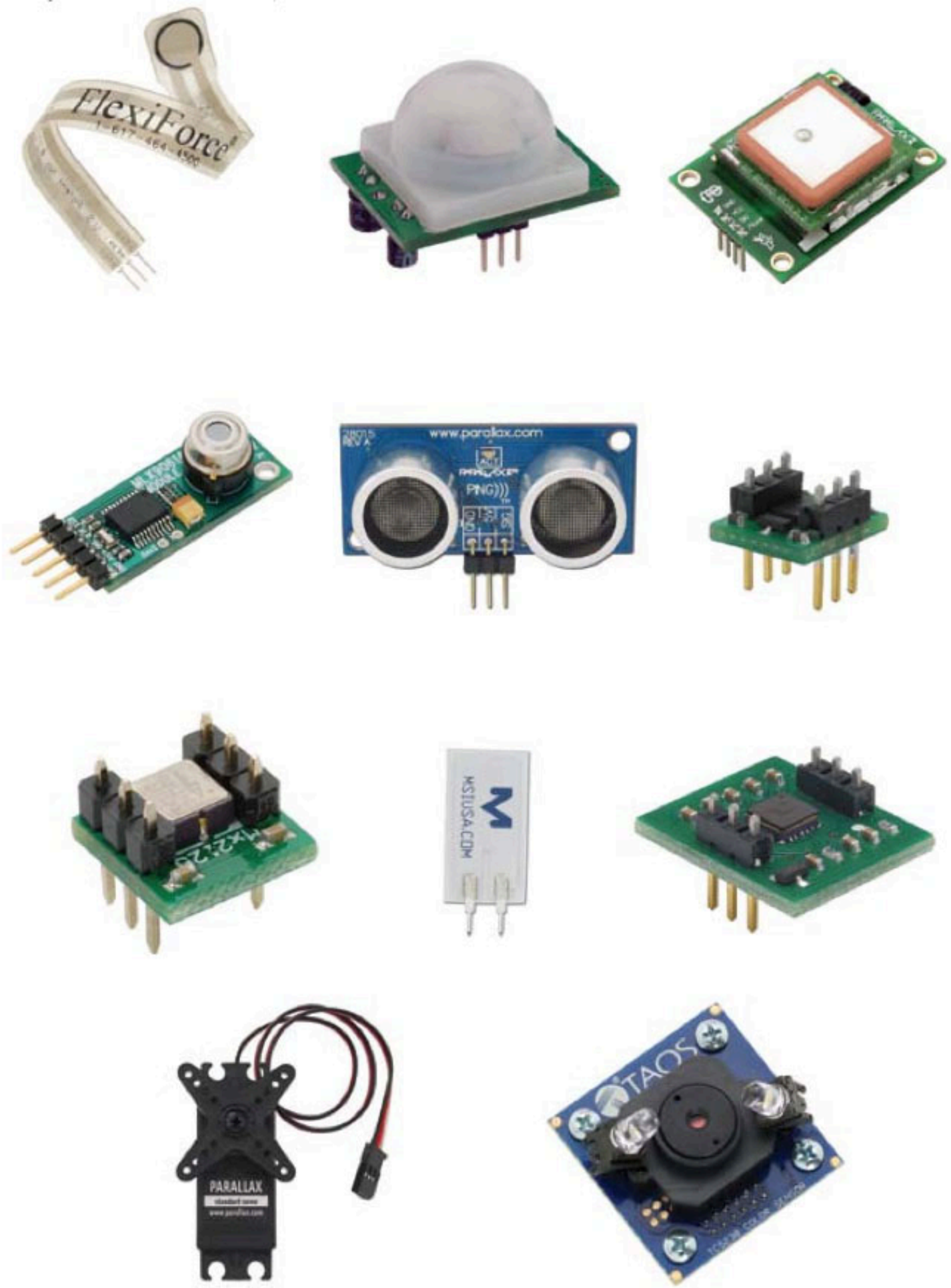

Figura 51: Componentes computacionais avançados - compostos por diferentes tipos de circuitos integrados - que se assemmelham a pequenos computadores (Fonte: FOX; KEMP, 2009, p.74) 
Existem diversos outros componentes, não abordados neste texto, que oferecem infinitas possibilidades, ao serem combinados. Os componentes computacionais podem ser considerados os blocos básicos de construção dos sistemas digitais. $\mathrm{O}$ importante para o contexto deste estudo é compreender algumas especificidades dos sistemas digitais, e a abordagem dos componentes computacionais, dos mais básicos até os altamente elaborados. Este é um dos caminhos que podem levar à expansão dos discursos e da prática da arquitetura interativa. De forma que,

0 objetivo da montagem de componentes de materiais inteligentes que servem como sensores, transdutores ou atuadores, é formar um sistema interligado completo que pode ser ativado ou controlado, para produzir uma ação intencionada ou para possuir características de resposta desejadas ${ }^{117}$ (ADDINGTON; SCHODEK, 2005, p.40).

Uma vez que a arquitetura interativa pressupõe a manipulação lógica da informação digital, os componentes passam a ser essenciais para sua conformação. A partir desta perspectiva, os espaços podem ser entendidos, até mesmo, como extensões físicas dos circuitos digitais.

A arquitetura interativa incorpora os componentes computacionais de diversas maneiras, de forma que circuitos integrados e processadores podem ser combinados com os inúmeros outros componentes disponíveis, no mercado, resultando em sistemas digitais, totalmente customizados. Da mesma maneira, o entendimento da estrutura e do funcionamento dos componentes permite a incorporação livre e criativa dos materiais. Porém, para que essas possibilidades sejam vislumbradas, são necessárias abordagens alternativas, em relação aos circuitos eletrônicos e aos materiais em geral. Essa releitura é o que torna possível a incorporação da tecnologia digital, enquanto material a ser manipulado de maneira inovadora nos projetos.

\subsubsection{Materiais Inteligentes}

A utilização dos materiais inteligentes para a criação de circuitos, na forma de elementos espaciais, requer uma outra postura dos arquitetos e designers. A Revolução Industrial - com seus novos materiais produzidos pela engenharia - mudou drasticamente a maneira de construir. Antes, o conhecimento de materiais era

\footnotetext{
117 Do original em inglês: The goal of assembling smart material components that serve as sensors, transducers or actuators is to form an interconnected whole system that can be activated or controlled to produce an overall intended action or to possess desired response characteristics (ADDINGTON; SCHODEK, 2005, p.40).
} 
empírico e intuitivo, obtido por meio da experiência e da observação, e a escolha era balizada por aspectos pragmáticos (utilidade e disponibilidade) ou formais (por sua aparência e qualidades ornamentais) (ADDINGTON; SCHODEK, 2005).

A engenharia do Século XIX, segundo Addington e Schodek (2005, p.3), viabilizou a manipulação de propriedades de materiais com o intuito de suprir necessidades específicas e "[...] como resultado, os arquitetos de hoje muitas vezes pensam nos materiais como parte de uma paleta de design da qual materiais podem ser escolhidos e aplicados como composições e superfícies visuais." ${ }^{118}$ Sobre isso, argumentam que estes novos materiais pressupõem outra maneira de pensar, e não devem ser considerados uma extensão lógica de uma perspectiva padronizada de catálogos de escolha, na qual o único conhecimento necessário é o das propriedades estáveis de cada material.

Assim, ao apresentar as características básicas desta nova classe de materiais, os autores sugerem outra maneira de pensar o espaço que não se restringe à utilização destes materiais. Apontam que, "[...] considerando que os materiais de construção padrões são estáticos de forma que se destinam a suportar as forças do edifício, materiais inteligentes são dinâmicos de forma que eles se comportam em relação a campos de energia"119 (ADDINGTON; SCHODEK, p.4). Nesse contexto, a abordagem proposta por esta pesquisa contempla não tecnologias específicas, as quais provavelmente irão se tornar obsoletas em pouco tempo, mas sim, o fenômeno particular da possibilidade de adicionar comportamentos programáveis aos espaços, que culmina em processos de criação de espaços, a partir de seu caráter dinâmico de uso.

Para explorar esta perspectiva, é necessário distinguir e caracterizar a definição, adotada neste estudo, do termo materiais inteligentes. Utiliza-se, aqui, a classificação proposta por Addington e Schodek (2005, p.15-30), na qual os materiais inteligentes são diferentes tanto dos materiais tradicionais quanto dos populares materiais de alta performance. Isso acontece, pois, por mais que muita tecnologia esteja presente em suas conformações - especialmente nos de alta performance, definidos como aqueles nos quais "[...] propriedades particulares foram otimizadas por meio do uso de

\footnotetext{
118 Do original em inglês: As a result, today's architects often think of materials as part of a design palette from which materials can be chosen and applied as compositional and visual surfaces (ADDINGTON; SCHODEK, 2005, p.3).

119 Do original em inglês: Whereas standard building materials are static in that they are intended to whithstand building forces, smart materials are dynamic in that they behave in response do energy fields (ADDINGTON; SCHODEK, 2005, p.4).
} 
específicas estruturas internas e composição de materiais"120 - ambos possuem como característica essencial "[...] respostas fixas a estímulos externos (as propriedades dos materiais permanecem constantes em condições normais." ${ }^{121}$

Com o intuito de delimitar a definição de materiais inteligentes, os autores identificaram cinco características que os definem como tal e os diferem de outros tipos de material (ADDINGTON; SCHODEK, 2005, p. 10). Seja na conformação de uma molécula, material, compósito, conjunto ou sistema, os materiais e tecnologias inteligentes exibirão sempre estas características, assim resumidas:

- Selectivity (seletividade): cada tipo de material responde de maneira específica e previsível a quantidades e tipos de estímulos específicos;

- Directness (direcionamento): a resposta é local ao evento que a está estimulando, ou seja, estímulo e reação acontecem no mesmo lugar;

- Immediacy (imediatismo): a resposta física acontece em tempo real, ou seja, ao mesmo tempo em que o estímulo acontece;

- Transiency (transitoriedade): respondem a variação de estímulos do ambiente;

- Self-actuation (auto-acionamento): a inteligência é interna ao material e não externa, a transformação acontece nele mesmo.

A observação dessas características, nestes novos materiais, levaram Addington e Schodek $(2005$, p.82) a propor a classificação destes materiais em dois tipos - 1 e 2 conforme ilustrado na Figura 52. No tipo 1 "[...] o material absorve a energia introduzida e sofre uma mudança", ou seja, trata-se de "[...] um material que muda uma de suas propriedades (química, ótica, elétrica, magnética ou térmica) em resposta a uma mudança nas condições de seu ambiente e, faz isso, sem a necessidade de controle externo". O tipo 2 são aqueles que "[...] o material permanece o mesmo, mas a energia sofre uma mudança", ou seja, trata-se de "[...] um material ou dispositivo que transforma a energia de um tipo para outro para alcançar um desejado estado final." 122

\footnotetext{
120 Do original em inglês: Particular properties have been optimizaed via the use of particular internal material structures or compositions (ADDINGTON; SCHODEK, 2005, p.15).

121 Do original em inglês: fixed responses to external stimuli (materials properties remain constant under normal conditions) (ADDINGTON; SCHODEK, 2005, p.30).

122 Do original em inglês: The material absorbs the input energy and undergoes a change (p.80), ou seja, $A$ material that changes one of its properties (chemical, optical, electrical, magnetic, or thermal) in response to a change in the conditions of its environment and does so without the need of external control (p.82). 0 tipo 2 são aqueles que The material stays the same but the energy undergoes a change (p.80), ou seja, tratam-se de $A$ material or device that transforms energy from one form to another to effect a desired final state (ADDINGTON; SCHODEK, 2005, p.82).
} 
Feita esta classificação, é importante esclarecer que um sistema de input/output composto por materiais inteligentes não precisa, necessariamente, estar ligado a controladores lógicos. É possível a exploração das propriedades destes materiais sem a introdução da tecnologia computacional, uma vez que, nesses casos, a necessidade de alteração da perspectiva de arquitetos e designers, em relação à responsividade do espaço se mantém. Para os autores, “[...] nosso ponto aqui, é que, pensar e projetar, em resposta a ações e comportamentos, ao invés de pensar em termos de artefatos e coisas, é facilitado, em vez de restrito, pelos os avanços em materiais e tecnologias" ${ }^{123}$ (ADDINGTON; SCHODEK, 2005, p.223).

\begin{tabular}{|c|c|c|}
\hline TYPE OF SMART MATERIAL & INPUT & OUTPUT \\
\hline \multicolumn{3}{|l|}{ Type 1 Property-changing } \\
\hline $\begin{array}{l}\text { Thermomochromics } \\
\text { Photochromics } \\
\text { Mechanochromics } \\
\text { Chemochromics } \\
\text { Electrochromics } \\
\text { Liquid crystals } \\
\text { Suspended particle } \\
\text { Electrorheological } \\
\text { Magnetorheological }\end{array}$ & $\begin{array}{l}\text { Temperature difference } \\
\text { Radiation (Light) } \\
\text { Deformation } \\
\text { Chemical concentration } \\
\text { Electric potential difference } \\
\text { Electric potential difference } \\
\text { Electric potential difference } \\
\text { Electric potential difference } \\
\text { Electric potential difference }\end{array}$ & $\begin{array}{l}\text { Color change } \\
\text { Color change } \\
\text { Color change } \\
\text { Color change } \\
\text { Color change } \\
\text { Color change } \\
\text { Color change } \\
\text { Stiffness/viscosity change } \\
\text { Stiffness/viscosity change }\end{array}$ \\
\hline \multicolumn{3}{|l|}{ Type 2 Energy-exchanging } \\
\hline $\begin{array}{l}\text { Electroluminescents } \\
\text { Photoluminescents } \\
\text { Chemoluminescents } \\
\text { Thermoluminescents } \\
\text { Light-emitting diodes } \\
\text { Photovoltaics }\end{array}$ & $\begin{array}{l}\text { Electric potential difference } \\
\text { Radiation } \\
\text { Chemical concentration } \\
\text { Temperature difference } \\
\text { Electric potential difference } \\
\text { Radiation (Light) }\end{array}$ & $\begin{array}{l}\text { Light } \\
\text { Light } \\
\text { Light } \\
\text { Light } \\
\text { Light } \\
\text { Electric potential difference }\end{array}$ \\
\hline \multicolumn{3}{|c|}{ Type 2 Energy-exchanging (reversible) } \\
\hline $\begin{array}{l}\text { Piezoelectric } \\
\text { Pyroelectric } \\
\text { Thermoelectric } \\
\text { Electrorestrictive } \\
\text { Magnetorestrictive }\end{array}$ & $\begin{array}{l}\text { Deformation } \\
\text { Temperature difference } \\
\text { Temperature difference } \\
\text { Electric potential difference } \\
\text { Magnetic field }\end{array}$ & $\begin{array}{l}\longleftrightarrow \text { Electric potential difference } \\
\longleftrightarrow \text { Electric potential difference } \\
\longleftrightarrow \text { Electric potential difference } \\
\longleftrightarrow \text { Deformation } \\
\longleftrightarrow \text { Deformation }\end{array}$ \\
\hline
\end{tabular}

Figura 52: Exemplos dos diferentes materiais tipo 1 e tipo 2 em relação aos seus respectivos outputs. (Fonte: ADDINGTON; SCHODEK, 2005, p.82)

Contudo, para esta pesquisa, a relevância destes materiais inteligentes reside em seu grande potencial, em relação ao fato de serem conectados e controlados por artefatos computacionais. Esses materiais tornam-se interessantes quando possibilitam controlar quando e porque as mudanças acontecerão (ADDINGTON; SCHODEK, 2005, p.109).

\footnotetext{
123 Do original em inglês: Our point here is that thinking and designing in response to actions and behaviors instead of in terms of artifacts and things is facilitated by, rather than restricted to, advancements in materials and technologies (ADDINGTON; SCHODEK, 2005, p.223).
} 
Neste sentido, os autores Vallgarda e Redström (2007, p.514) fundamentam a perspectiva na qual, dado o caráter criativo dos computadores, se a computação for considerada como um tipo específico de material - e os autores argumentam justamente a validade deste ponto de vista - sua combinação com outros materiais criaria o que eles denominam de compósitos computacionais (computational composites). Eles propõem que "[...] como a tecnologia computacional não é mais apenas uma ferramenta, poderia em vez disso ser vista como um material - um material muito parecido com qualquer outro material que usamos para projetas as coisas" $^{124}$.

A ideia de compósitos computacionais permite a exploração de diferentes possibilidades de integração da computação com outros materiais. Nesse caso, as propriedades dinâmicas dos materiais apresentados, neste tópico, seriam justamente o meio pelo qual as estruturas interativas geradas por processos computacionais se manifestariam. Segundo Vallgarda e Redström (2007, p.517),

Compósitos são feitos para realçar propriedades específicas ou para introduzir novas propriedades combinando certos materiais em certas maneiras. Com os compósitos computacionais, é essencialmente uma questão da introdução novas combinações de propriedades; isto é, introduzir a habilidade de computações digitais junto com propriedades de tensão, propriedades óticas, propriedades elétricas, propriedades térmicas e de isolamento, propriedades acústicas, deformações, deteriorações, aparências e assim por diante. ${ }^{125}$

A partir de fundamentos similares, Coelho (2008) analisa o processo de criação de compósitos para a interação. Seu estudo ilustra bem o tipo de trabalho criativo que envolve a apropriação destes materiais inteligentes, de maneira a explorar com consciência e profundidade seu potencial. O autor explora configurações de compósitos computacionais, a partir da utilização de um material específico, o shape memory alloy (liga com memória formal) - uma liga de titânio e níquel classificada como tipo 2, que retoma sua geometria inicial com a aplicação de calor.

\footnotetext{
124 Do original em inglês: We propose that, as computational technology is no longer just a tool, it could instead be seen as a material - a material much like any other material we use to design things (VALLGARDA; REDSTRÖM, 2007, p.514).

125 em inglês: Composites are made to enhance specific properties or to introduce new properties by combining certain materials in certain ways. With computational composites, it is primarily a question of introducing new combinations of properties; namely, to introduce the ability of digital computations together with tensile properties, optical properties, electrical properties, thermal properties and insulation, acoustic properties, deformations, deterioration, appearance and so forth (VALLGARDA; REDSTRÖM, 2007,p.517).
} 
Em síntese, o processo de deformação desse material acontece da seguinte maneira: aquece-se o material em alta temperatura (aprox. $500^{\circ} \mathrm{C}$ ) e, enquanto o material está nessa temperatura, a maneira na qual for moldado neste estado passará a ser, a partir de então, seu estado original. Quando o material volta a estar em temperatura ambiente, torna-se bastante maleável e posse ser facilmente moldado. Uma vez que a temperatura de transição é aplicada (aprox. $60^{\circ} \mathrm{C}$ ), independente do que foi feito, o material retoma aquele estado original. Esse processo pode, então, ser repetido incontáveis vezes e a temperatura de transição pode ser aplicada por meio de corrente elétrica, o que o torna passível de ser controlado por circuitos digitais.

Coelho (2008, p.50) explora configurações deste material em três propostas. A primeira, Surflex (Figura 53), trata-se de "[...] uma arquitetura de material na qual a superfície pode adotar diferentes topologias por meio da combinação de compressão e alongamento nas principais direções, bem parecido com as superfícies digitais baseadas em NURB". A segunda, denominada Sprout I/O (Figura 54) trata-se de um compósito cujo comportamento "[...] altera as qualidades tátil e visual da superfície por meio de uma textura que altera a forma, no lugar de sua topologia geral". A terceira são os Shutters (Figura 55), que “[...] quebram a continuidade da superfície por meio de pequenas perfurações controláveis que modulam a permeabilidade entre dois espaços" $^{126}$.
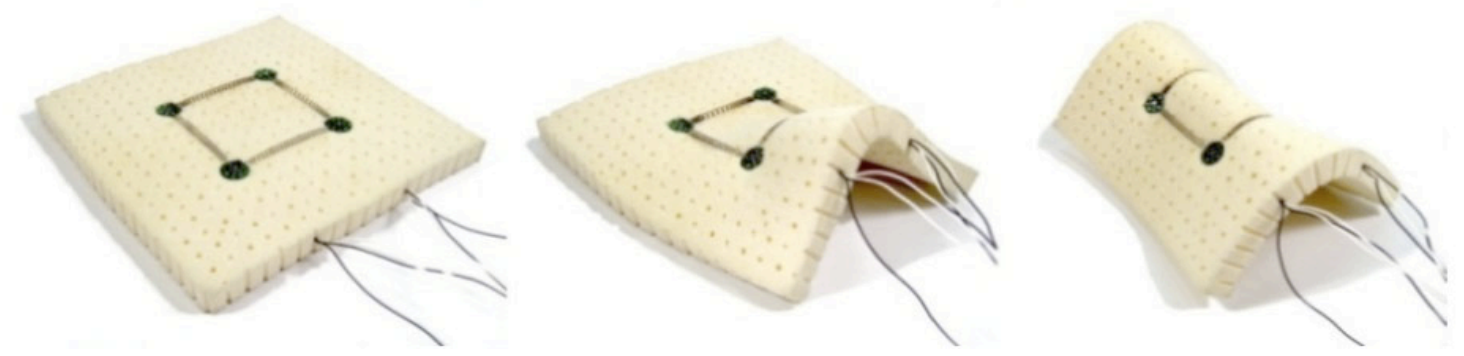

Figura 53 : Deformação da superfície Surflex em três etapas (Fonte: COELHO, 2005, p. 57)

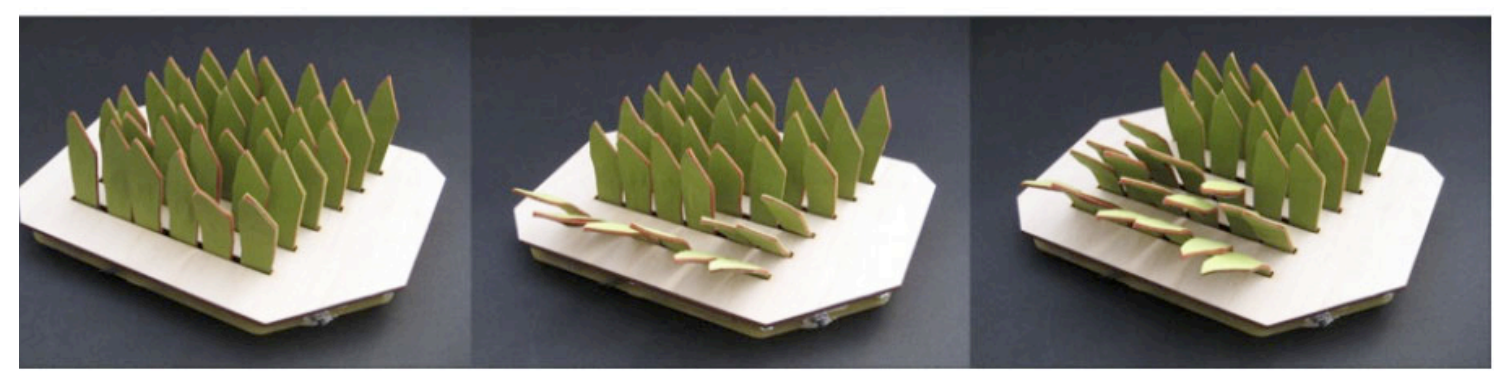

Figura 54 : Alteração da textura do Sprout I/O (Fonte: COELHO, 2005, p. 65)

126 Do original em inglês: [...] a material architecture in which a surface can adopt different topologies by combining compression and elongations in the principal directions, much alike NURB-based digital surfaces [...] change the tactile and visual qualities of the surface through a shape changing texture, rather than its overall topology [...] breaks the surface continuity by using small controllable perforations to modulate the permeability between two spaces (COELHO, 2008, p.50). 


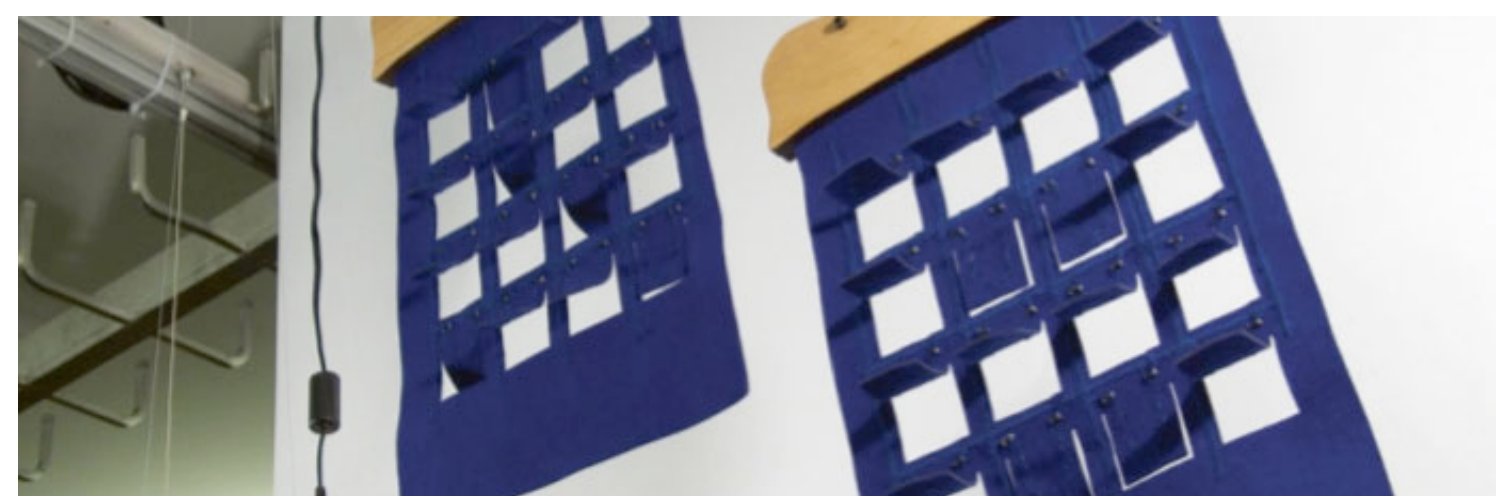

Figura 55: As superfícies Shutter são controladas por um circuito localizado no painel de madeira. O Shutter da direita possui suas aberturas arranjadas para mostrar a letra 'A' (Fonte: COELHO, 2005, p. 77)

Estas investigações ilustram outro aspecto importante na introdução dos materiais inteligentes na de criação de artefatos interativos, no qual "[...] designers de interação, arquitetos e artistas são obrigados a desempenhar um papel muito maior no desenvolvimento do material, no seu caminho para se tornar um produto"127 (VALLGARDA; REDSTRÖM, 2007, p.521). Assim, o design passa a contemplar, também, a estruturação de como estes compósitos são criados e adotados.

Os principais desafios na criação de compósitos responsivos são triplos:

1) Encontrar as combinações apropriadas de materiais;

2) Desenvolver as técnicas de fabricação para colocá-los juntos de maneira que tirem vantagem de suas propriedades; e finalmente

3) Interfaceá-los com o circuito lógico que pode controlar seu comportamento. ${ }^{128}$ (COELHO, 2008, p. 26)

Também neste contexto de experimentação com materiais, vale também mencionar a perspectiva adotada por Perner-Wilson (2011), que busca desenvolver e divulgar processos para a criação de compósitos computacionais, a partir da fabricação manual das partes, aproximando o trabalho com materiais inteligentes daqueles desenvolvidos por artesãos, como ilustrado na Figura 56-57. Trata-se de:

Uma nova aproximação na construção de eletrônicos que enfatiza as qualidades expressivas de diversos materiais assim como as habilidades e criatividade do construtor. Essa aproximação é representada por meio de uma série de técnicas que incluem, entre outras coisas, maneira de esculpir conexões elétricas, cortar

\footnotetext{
127 Do original em inglês: Interaction designers, architects and artists are bound to play a much larger role developing the material on its way to become a product (VALLGARDA; REDSTRÖM, 2007, p.521).

128 Do original em inglês: The main challenges in creating responsive composites are three-fold: (1) finding the appropriate material combinations; (2) developing the fabrication techniques for putting them together in a way that takes advantage of their properties; and finally (3) interfacing them to the logic circuitry that can control their behavior (COELHO, 2008, p. 26).
} 
alto-falantes de papel, esculpir mostradores de madeira e pintar pixels que mudam de cor ${ }^{129}$ (PERNER-WILSON, 2011, p.6).
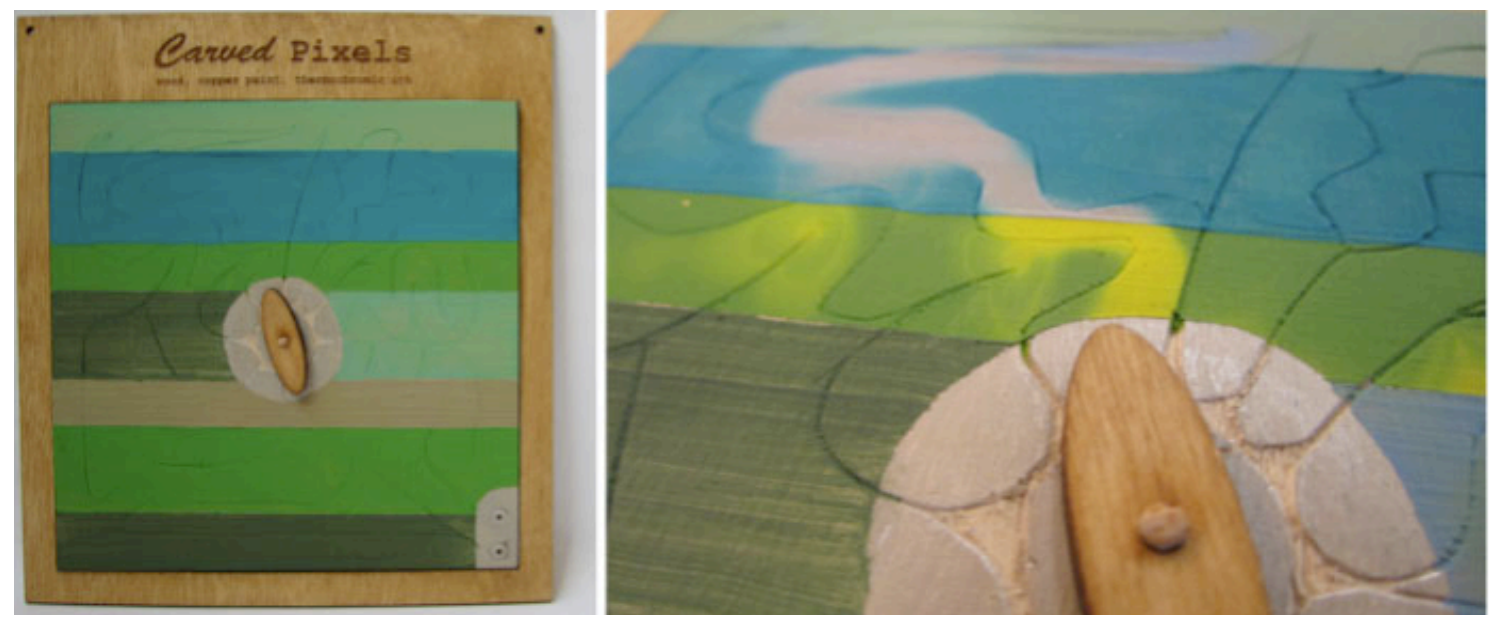

Figura 56-57: Pixels termocrômicos: a direção para qual o indicador aponta marca o direcionamento da corrente elétrica, responsável pela alteração de propriedades da tinta termocrômica (Fonte: PERNER-WILSON, 2011, p.56)

Considerando este contexto de materiais inteligentes e comportamento dos espaços, percebe-se a necessidade de se mudar o paradigma de projeto na arquitetura, que atualmente precisa, também, desenvolver meios para pensar os aspectos dinâmicos do espaço. Segundo Addington e Schodek (2005, p.228),

0 potencial, entretanto, para repensar nossa implementação normativa de materiais se estende muito além das noções de eficiência e conveniência. [...] 0 artefato poderia apoiar a intenção de projeto, no lugar de ser sua manifestação física. Voltamos às perguntas do que a experiência poderia ser, o que os ocupantes deveriam sentir e como eles interagiriam com seus ambientes. Em vez de projetar em larga escala para produzir efeitos auxiliares, poderíamos ser capazes de projetar em pequena escala para produzir uma maior experiência humana. ${ }^{130}$

As utilizações de recursos luminosos e cinéticos complementam a leitura, aqui proposta da estrutura da arquitetura interativa. Trata-se de linhas de pensamento e atuação que, até certo ponto, estão desenvolvendo histórias e discursos próprios, tal como pode ser observado em Haeusler (2009), bem como em Fox e Kemp (2009). Porém, no contexto desta pesquisa, uma vez que a iluminação e o movimento são controlados por circuitos eletrônicos, tratam-se de manifestações específicas da

\footnotetext{
129 Do original em inglês: A new approach to building electronics that emphasizes the expressive qualities of diverse materials as well as the skill and creativity of the builder. This approach is represented through a set of techniques that include, among other things, ways to sculpt and plate electrical connections, cut paper speakers, carve wooden dials and paint color-changing pixels (PERNER-WILSON, 2011, p.6).

130 Do original em inglês: The potential, however, for rethinking our normative deployment of materials extends far beyond the notions of efficiency and expediency. [...] The artifact could support the design intent, instead of being its physical manifestation. We come back to the questions of what the experience could be, what the occupants should feel, how would they interact with their surroundings. Instead of designing at a large scale to produce ancillary effects, we might be able to design at the small scale to produce a larger human experience (ADDINGTON; SCHODEK, 2005, p.228).
} 
arquitetura interativa como um todo, interligadas à introdução do pensamento computacional no processo de criação, implementação de circuitos lógicos digitais no produto final e manipulação de materiais inteligentes.

\subsubsection{Iluminação dinâmica}

A luz é um elemento essencial da arquitetura, seja ela natural ou artificial, de forma que sua manipulação simbólica ou funcional, relaciona-se diretamente com os contextos técnicos e sociais, de cada época. Desde os vitrais do século XIII até a incorporação da energia elétrica, nos espaços no final do século XIX, a apropriação de diferentes soluções luminosas ilustram combinações entre inovação técnica e expressão estética. Com a tecnologia digital, comportamentos luminosos mais complexos tornaram-se possíveis de serem implementados. Com isso, as possibilidades comunicativas do espaço passaram a incluir, além dos recursos tradicionais, textos, gráficos e imagens em movimento. Essa é a principal característica das mídias fachadas, cuja história, classificação e critérios para criação são aprofundados por Haeusler (2009).

O campo emergente das mídias fachadas é tanto qualitativo quanto quantitativo. Em termos qualitativos: formas de melhorar a relação, qualidade, funcionalidade e os elementos dinâmicos dos edifícios urbanos e dos espaços públicos em termos de critérios de design, social, cultural e econômico. Em termos quantitativos: processos tecnológicos de prototipagem e aplicações para a combinação multiforme de: edifícios e espaços urbanos, com displays digitais visuais dinâmicos de informação multimídia, e atividades e interações humanas contextualizadas.131 (HAEUSLER, 2009, p.7)

Para classificar e separar os diferentes tipos de mídia fachada, o autor as categoriza de acordo com sua composição técnica, e as define em quatro grupos principais: tecnologias mecânicas, de projeção, de iluminação e de telas. Para a perspectiva proposta para esta pesquisa, os dois últimos serão abordados detalhadamente, pois fornecem elementos importantes para o entendimento da utilização de recursos luminosos na arquitetura interativa.

\footnotetext{
131 Do original em inglês: The emergent field of media facades is both qualitative and quantitative. In qualitative terms: ways of enhancing the engagement, quality, functionality and dynamic elements of urban buildings and public spaces in terms of design, social, cultural and economic criteria. In quantitative terms: prototyping and application-based, technological methods for the coherent multi-way combination of: buildings and urban spaces, with dynamic visual digital displays of multimedia information, and locality-based human activities and interaction (HAEUSLER, 2009, p.7).
} 
As tecnologias mecânicas serão tratadas, no próximo tópico, por se entender que elas estão relacionadas, diretamente, com a exploração do movimento para adicionar dinâmica aos espaços. As tecnologias de projeção, apesar de serem recursos interessantes, especialmente devido ao seu custo-benefício, não envolvem a introdução de elementos eletrônicos na estrutura da arquitetura, e, assim, foge do escopo do objeto desta pesquisa. Contudo, é inegável que seu emprego proporciona possibilidades de exploração de interações, espacialidades e sensações consideradas importantes e que merecem outros estudos mais aprofundados.

As tecnologias de iluminação (illuminant technologies) compreendem a utilização de lâmpadas tradicionais para a implementação da fachada interativa, tais como incandescentes e eletroluminescentes. Os efeitos luminosos possíveis dependem do formato da lâmpada e da possibilidade de controle de sua intensidade. Algumas podem apenas ser ligadas ou desligadas, enquanto outras, ao serem controladas, oferecem mais opções de gradação.
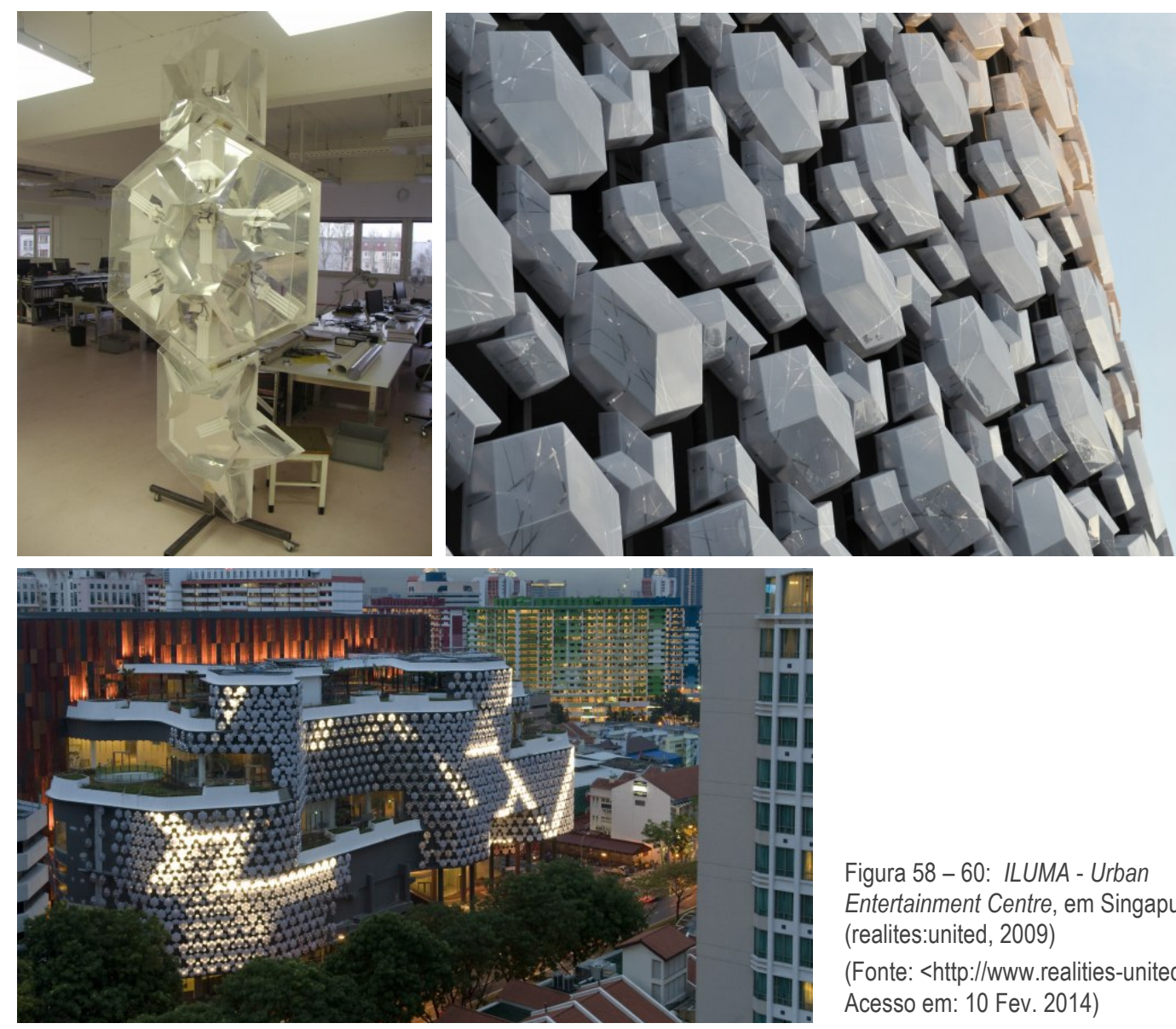

Figura 58 - 60: ILUMA - Urban

Entertainment Centre, em Singapura (realites:united, 2009)

(Fonte: <http://www.realities-united.de> Acesso em: 10 Fev. 2014)

A fachada $B I X$, citada anteriormente, é um exemplo que incorpora lâmpadas tradicionais na estrutura do edifício do qual faz parte. Outro projeto do mesmo escritório, realites:united, a fachada do ILUMA (Urban Entertainment Centre, em 
Singapura, 2009) também tira proveito de tecnologias tradicionais de iluminação (Figura 58 e 60). Nessa proposta, a intenção foi mesclar a tecnologia com elementos ornamentais da fachada. Se durante a noite, a fachada exibe conteúdos luminosos, durante o dia "[...] a tela gigante produzida pelas lâmpadas são nitidamente distorcidas pelos fortes padrões geométricos formados pelos dispositivos luminosos"132 (Haeusler, 2009, p.103).

Outra estratégia, para incorporar lâmpadas e conferir dinâmica à arquitetura, é assumir as próprias janelas do edifício como pixels de uma tela, solução da primeira mídia fachada construída, a Blinkenlights (2001, Figura 61-63). 144 lâmpadas foram instaladas nas janelas de um edifício em Berlim, resultando em uma matriz de 8x8 pixels, em comemoração ao vigésimo aniversário do Chaos Computer Club. Cada lâmpada era controlada, independentemente, por um software fácil de usar que possibilitou a implementação de diversas dinâmicas interativas. Com o uso do celular, as pessoas podiam ativar e jogar o jogo pong, assim como enviar imagens e animações para serem mostradas. "Com uma tela tão grande em um local de destaque como a Alexanderplatz, ofereceu-se uma plataforma perfeita para a participação do público em variados distintos eventos e animações nas quase 24 semanas que a instalação estava montada"133 (HAEUSLER, 2009, p.109).
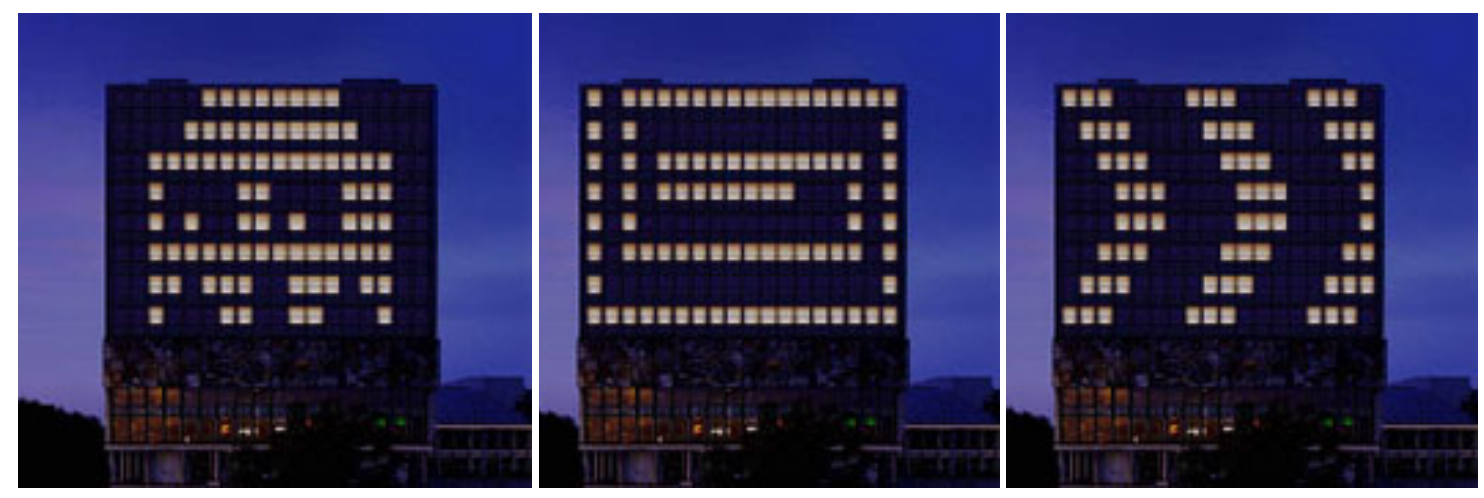

Figura 61-63: Projeto Blinkenlights (Caos Computer Club, 2001) (Fonte: <http://www.lab-au.com> Acesso em: 10 Fev. 2014)

As tecnologias de telas (display technologies), envolveram os diversos tipos de telas posteriores às tradicionais TVs de tubo catódico. No geral, as tecnologias recentes "[...] oferecem novas maneiras de incorporar a mídia na arquitetura e desempenharão um papel importante no futuro" (Haeusler, 2009, p.116). Devido ao seu baixo custo, alta durabilidade e fácil manuseio, o LED (light emiting diode), tem sido uma solução

\footnotetext{
132 Do original em inglês: The giant screen produced by the lamps is vividly distorted by the strong geometric patterns formed by the light fixtures (HAEUSLER, 2009, p.103).

133 Do original em inglês: Having such a vast screen in a prominent location like the Alexanderplatz offered a perfect platform for public participation at a number of different events and animations in the nearly 24 weeks the installation was in place (HAEUSLER, 2009, p.109).
} 
recorrente nas mídia fachadas. As soluções que utilizam LED compreendem tanto estruturas comerciais, concebidas para serem adaptadas a diversos tipos de espaços, quanto soluções customizadas, desenvolvidas como parte do projeto como um todo.

No caso da Stealth - tecnologia que compreende painéis modulares de $40 \times 40 \mathrm{~cm}$, com 256 LEDS e peso de apenas $1 \mathrm{~kg}$ - permeabilidade visual, leveza e facilidade de montagem/desmontagem foram os critérios norteadores de seu desenvolvimento. "Cada tela pode ser dobrada como sanfona diretamente para dentro e fora de uma maleta para turnês que satisfaz os requerimentos de um processo de instalação rápido e fácil” ${ }^{134}$. O sistema foi elaborado para atuar de maneira autônoma, incluindo a alimentação de energia, conexão de dados, estrutura de montagem e processamento em vídeo. "Os painéis podem ser montador em displays bem grande e moldados tanto em displays planos quanto curvos, com as tiras orientadas tanto na horizontal quanto na vertical”135 (HAEUSLER, 2009, p.121).

Diferentemente, a prioridade dada na criação da MiPix 20 (Figura 64) foi a versatilidade de aplicação. No lugar de painéis, essa tecnologia permite a montagem de displays em qualquer formato e tamanho, por meio da conexão de pequenos blocos de LED que medem apenas $40 \times 40 \mathrm{~mm}$. A leveza e adaptabilidade do sistema permitem sua incorporação em superfícies já existentes. Foi essa a tecnologia utilizada, por exemplo, no Uniqa Tower em Viena (2006, Figura 65-67), cujo exterior foi transformado em uma mídia fachada em um edifício já ocupado, assim descrita por Haeusler (2009, p.137):

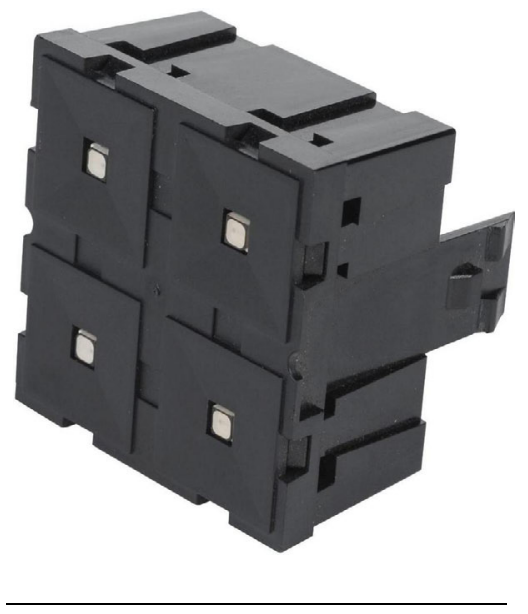

À noite, a instalação mostra um exemplo sem precedentes da relevância arquitetônica do vídeo. 0 cenário visual "voltas e reviravoltas" [twist and turns] consiste em linhas e constelações enquadradas que interpretam o edifício, pela execução em várias direções, calibres e formas. 0 resultados é uma forma dinâmica de arquitetura proveniente do edifício existente. ${ }^{136}$

\footnotetext{
134 Do original em inglês: Each screen can be fan-folded directly into and out of a touring case that satisfies the requirements of a quick and easy installation process (HAEUSLER, 2009, p.121).

135 Do original em inglês: The panels can be assembled into very large displays and formed into either flat or curved displays with either a horizontal or vertical orientation of the strips (HAEUSLER, 2009, p.121).

136 Do original em inglês: At night, the installation shows an unprecedented example of the architectural relevance of video. The visual scenario twists and turns consist of line and framework constellations that interpret the building by running in various directions, gauges and forms. The results is a dynamic form of architecture that comes from the existing building (HAEUSLER, 2009, p.137).
} 

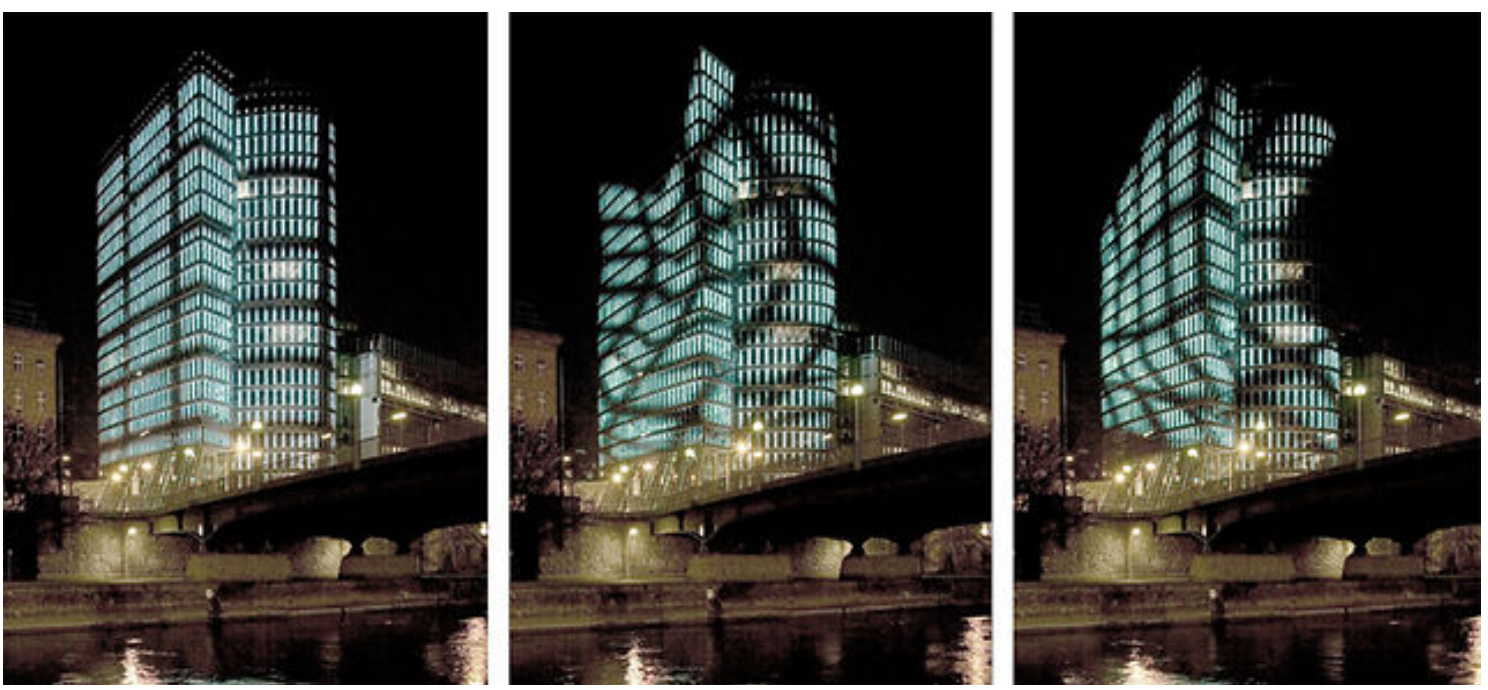

Figura 64 - superior: Módulo do sistema MiPix 20 (Fonte: <http://www.barco.com> Acesso em 10 Fev. 2014)

Figura 65-67 - inferior: Uniqa Tower (Viena, 2006) (Fonte: Foto de Hervé Massard. In: HAEUSLER, 2009, p.138)

As soluções customizadas, normalmente, se desdobram como parte integral das propostas arquitetônicas. É o caso, por exemplo, do espaço destinado ao Museu da $B M W$ (2008, Figura 68) em Munique, na Alemanha. Joachim Sauter, fundador e diretor do $A R T+C O M$, um dos parceiros do projeto, contou detalhes sobre seu desenvolvimento, em entrevista concedida a esta pesquisa. Uma descrição mais detalhada da criação deste tipo de arquitetura revela um exemplo de aplicação da tecnologia digital, fundamentada nos princípios e intenções do projeto.

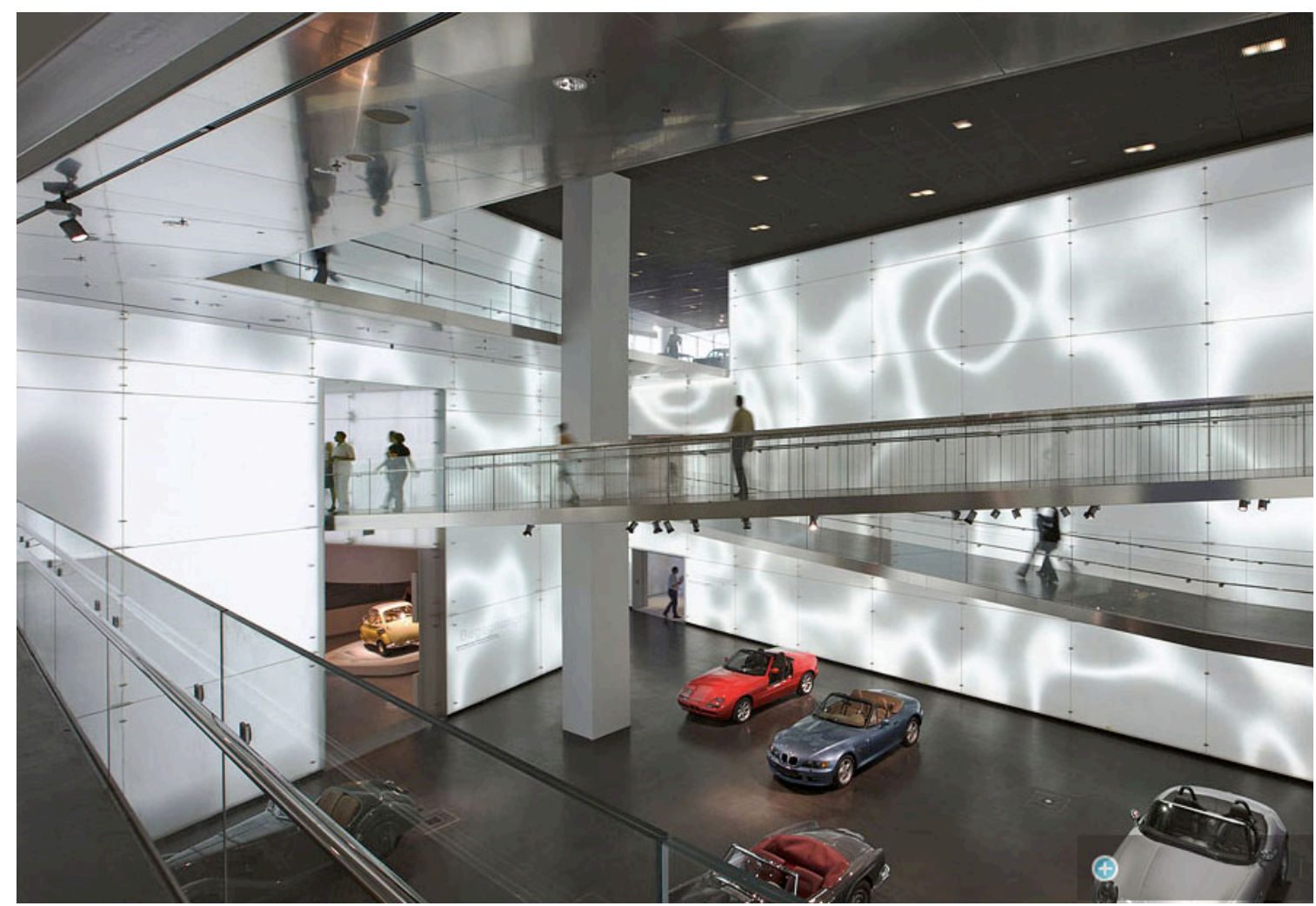

Figura 68 - Átrio central do Museu da BMW (ART+COM, 2008) (Fonte: <http://www.artcom.de/en/projects/detail/spheres> Acesso em: 10 Fev. 2014) 


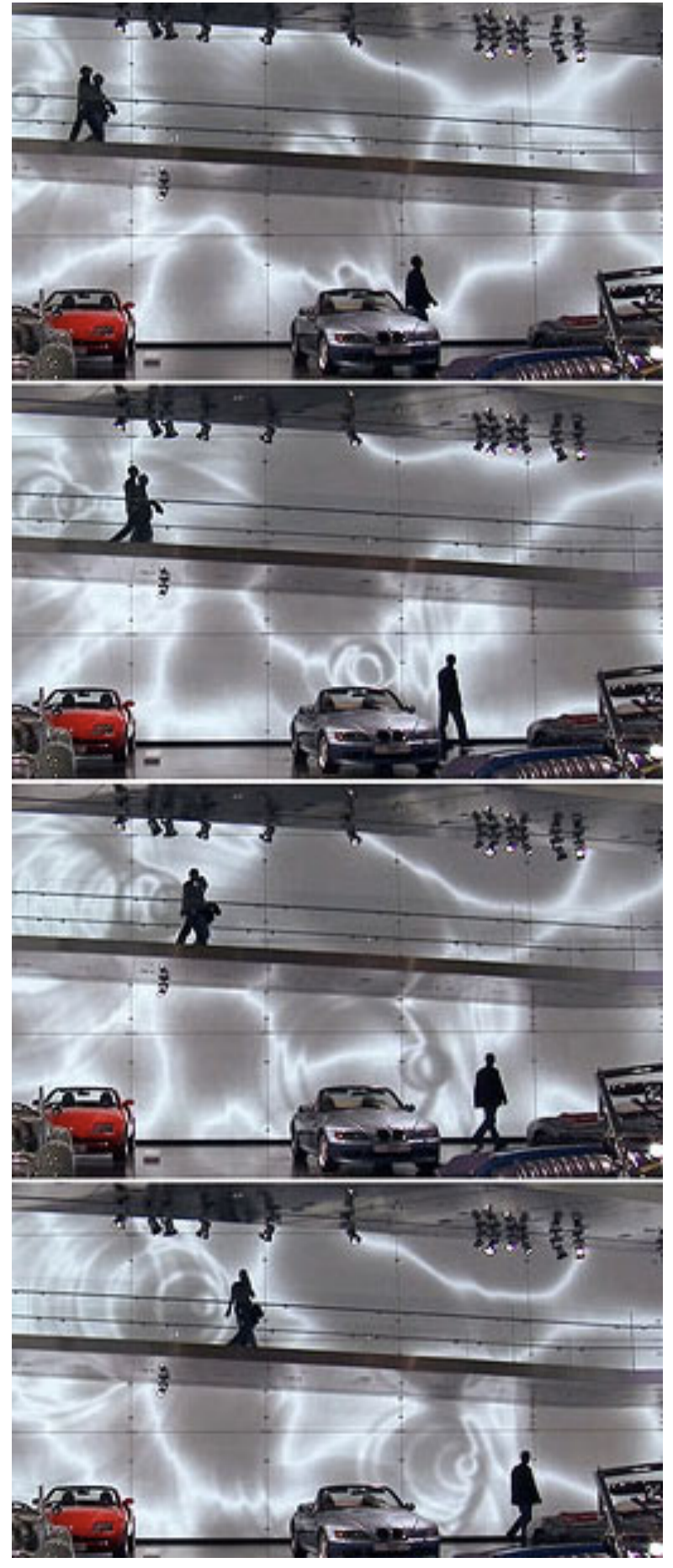

Figura 69 - Átrio central do Museu da BMW: animação interativa - responde ao movimento das pessoas pelo àtrio (ART+COM, 2008) (Fonte: $<$ http://www.artcom.de/en/projects/detail/spheres> Acesso em: 10 Fev. 2014)

Segundo Sauter (2011), o Museu já existia e o novo projeto tinha como objetivo a renovação e expansão de seu espaço. Um aspecto interessante é que, diferente do projeto $B I X$, no qual a fachada foi incorporada ao edifício depois que as principais decisões formais e estruturais já haviam sido tomadas pelos arquitetos, o escritório de mídia design $A R T+C O M$ foi o primeiro a ser contatado. Após as primeiras conversas com os clientes, sobre o espaço e a exposição como um todo, é que foram escolhidos os arquitetos que complementariam a equipe. 
Na entrevista, Sauter (2010) cita três motivações que levaram à introdução de uma mídia fachada no interior do museu. A primeira foi o fato de o museu ser construído em um espaço já existente, a sede da BMW, ter limitado significativamente sua dimensão. A mídia fachada foi, então, pensada como um meio de ampliar o espaço com animações 3D e movimentos (Figura 69).

A segunda, refere-se ao reflexo da projeção nos carros. Sua presença contribui para a percepção pelas pessoas, dos carros como elementos em movimentos, simulando a forma como são realmente apreendidos quando utilizados. Essa estratégia deriva do fato que, carros, foram feitos para serem dirigidos e sua percepção, nas ruas, é sempre definida por seu volume e pelos reflexos por onde passam.

Por último, o museu foi construído interligando diversos edifícios já existentes. Assim, o caminho que os visitantes percorrem faz com que passem diversas vezes por um mesmo átrio central, cujas paredes são totalmente cobertas pela mídia fachada. As animações fazem com que esse saguão principal seja sempre diferente, o que adiciona algo à dimensão do espaço, ao mapa mental que cada pessoa constrói dele, já, que sempre que ela volta, ele está diferente.
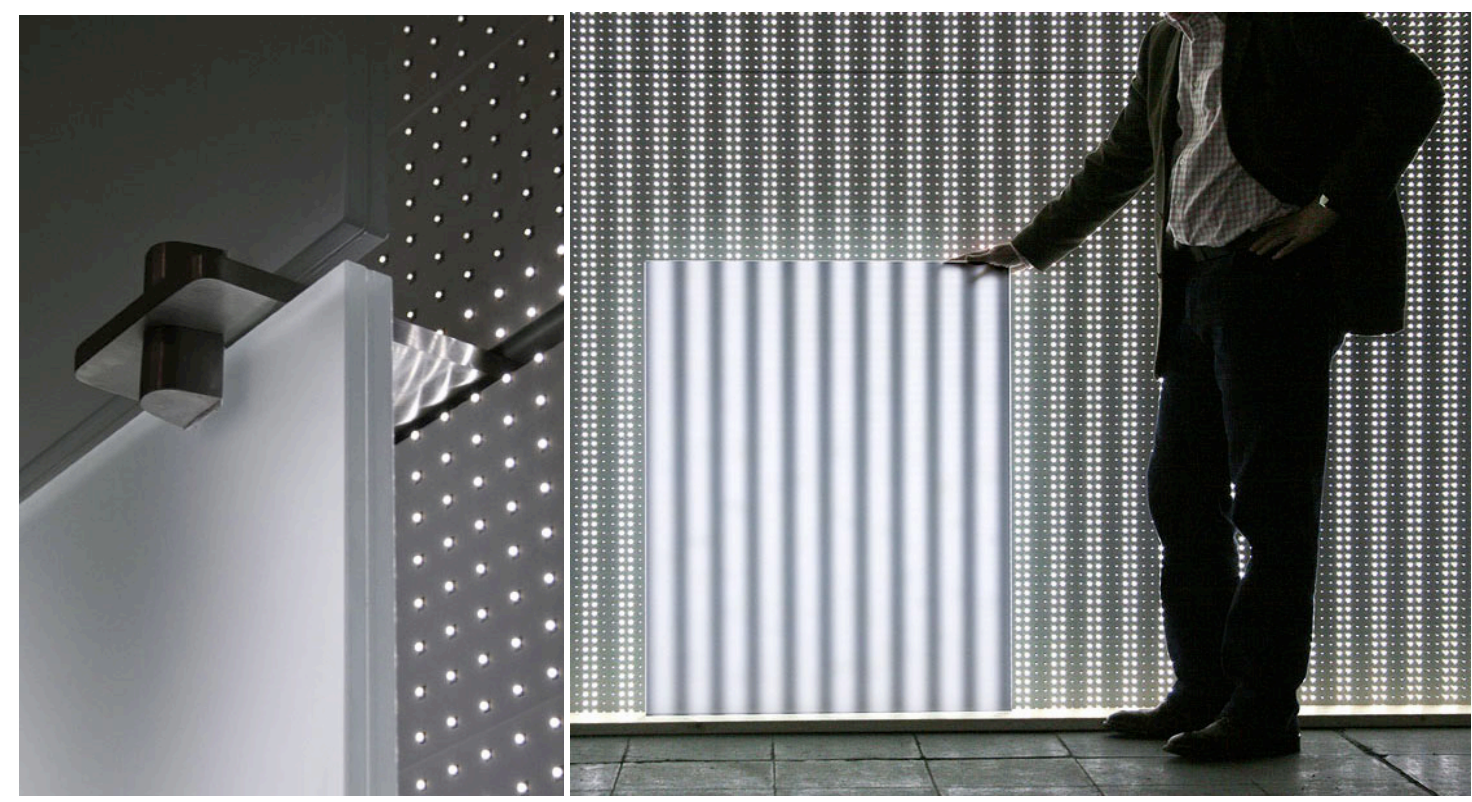

Figura 70-71 - Detalhe da estrutura de LEDs e de seu efeito luminoso (ART+COM, 2008)

(Fonte: <http://www.artcom.de/en/projects/detail/spheres> Acesso em: 10 Fev. 2014)

Definidas as motivações, o próximo passo foi resolver o que seria essa mídia fachada. Nesse momento, outros critérios passaram a ser considerados. O principal deles foi ter sempre em mente que a exposição era sobre os carros, de forma que estes deveriam se destacar no primeiro plano. Assim, procuraram, ao máximo, se afastar da ideia de uma grande tela, buscando um balanço ideal entre arquitetura e imagens em 
movimento de forma a manter o espaço, na maioria do tempo, na periferia da percepção das pessoas. Como solução, a equipe optou por um tom monocromático que explora as variações de intensidade de LEDs brancos, espalhados de dois em dois centímetros e sobrepostos por uma placa opaca que atua como difusora das luzes, suavizando seu efeito (Figura 70-71). No total foram utilizados mais de 1.7 milhões de LEDs controlados, individualmente, para cobrir toda a superfície do átrio central, cerca de $700 \mathrm{~m}^{2}$.

A definição do conteúdo foi também essencial para o escopo do projeto. Segundo Sauter (2010), foi necessário um trabalho de capacitação, com o cliente, para que eles compreendessem a ideia de que, apenas conteúdos abstratos seriam veiculados na fachada. Isso para não ocorrer o que tipicamente acontece, "[...] quando você cria uma mídia fachada, no começo todos os clientes gostam dessas superfícies computacionais bonitas, mas depois de um tempo eles passam a mostrar publicidade". No total, foram preparadas mais de vinte animações para a fachada, de forma que algumas respondem à presença das pessoas na exposição. Ao final, o projeto foi muito bem sucedido, como aponta Sauter (2010):

\footnotetext{
"Existem bons momentos na vida e existem maus momentos na vida. Esse foi um bom momento porque tudo funcionou da maneira que esperávamos. A coisa mais importante para as paredes, essas mídia paredes, era que elas não ficassem tanto no primeiro plano de forma que as pessoas não olhassem para os carros, já que este é um museu sobre carros e não sobre mídia arquitetura. Em todas as observações e filmagens que fizemos, percebe-se que as pessoas ficam impressionadas assim quando chegam, mas depois elas continuam andando e apenas de tempo em tempo elas olham novamente para cima e para as paredes. Isso é exatamente o que queríamos prover, algo que não está no primeiro plano, mas que produz uma extensão do espaço, esse tipo de sensação especial no espaço, e acho que nesse ponto nós realmente fomos bem sucedidos."
}

Utilizar recursos luminosos para adicionar dinâmica ao espaço e, ao mesmo tempo, almejar por uma arquitetura interativa que se mantenha na periferia da percepção das pessoas, foram, também, critérios importantes para o desenvolvimento do Ambiente Interativo D3 (CARNEIRO, 2011). Nesse projeto de interiores de uma sala comercial de aproximadamente $40 \mathrm{~m} 2$ (Figura 72 ) triângulos luminosos foram inseridos no desenho da marcenaria do espaço e customizados um a um.

A intenção era, em primeiro lugar, adicionar dinâmica e interatividade ao espaço como representação do tipo de trabalho que é desenvolvido pela empresa. Em segundo 
lugar, o fato de empresa criar conteúdos interativos para a internet e para aparatos móveis, embasou a criação de um espaço que, além de abrigar atividades criativas, também fomentasse a inventividade das pessoas que trabalhavam ali. Por este motivo, a arquitetura de sensores e atuadores foi elaborada para atuar como plataforma de experimentação de conteúdos.

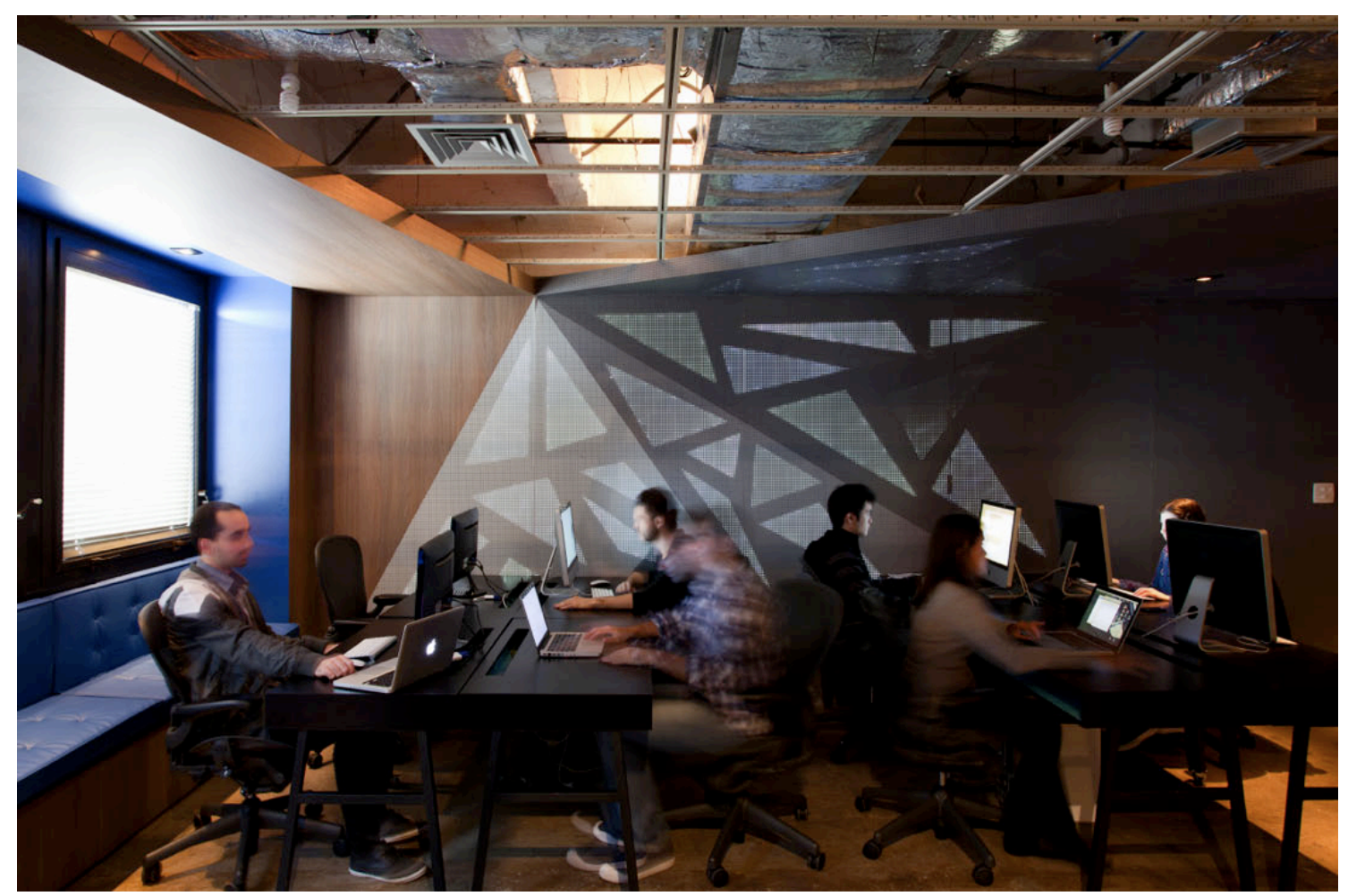

Figura 72: Ambiente Interativo D3 (Estúdio Guto Requena e i|o Design, 2011) (Fonte: Fran Parente)
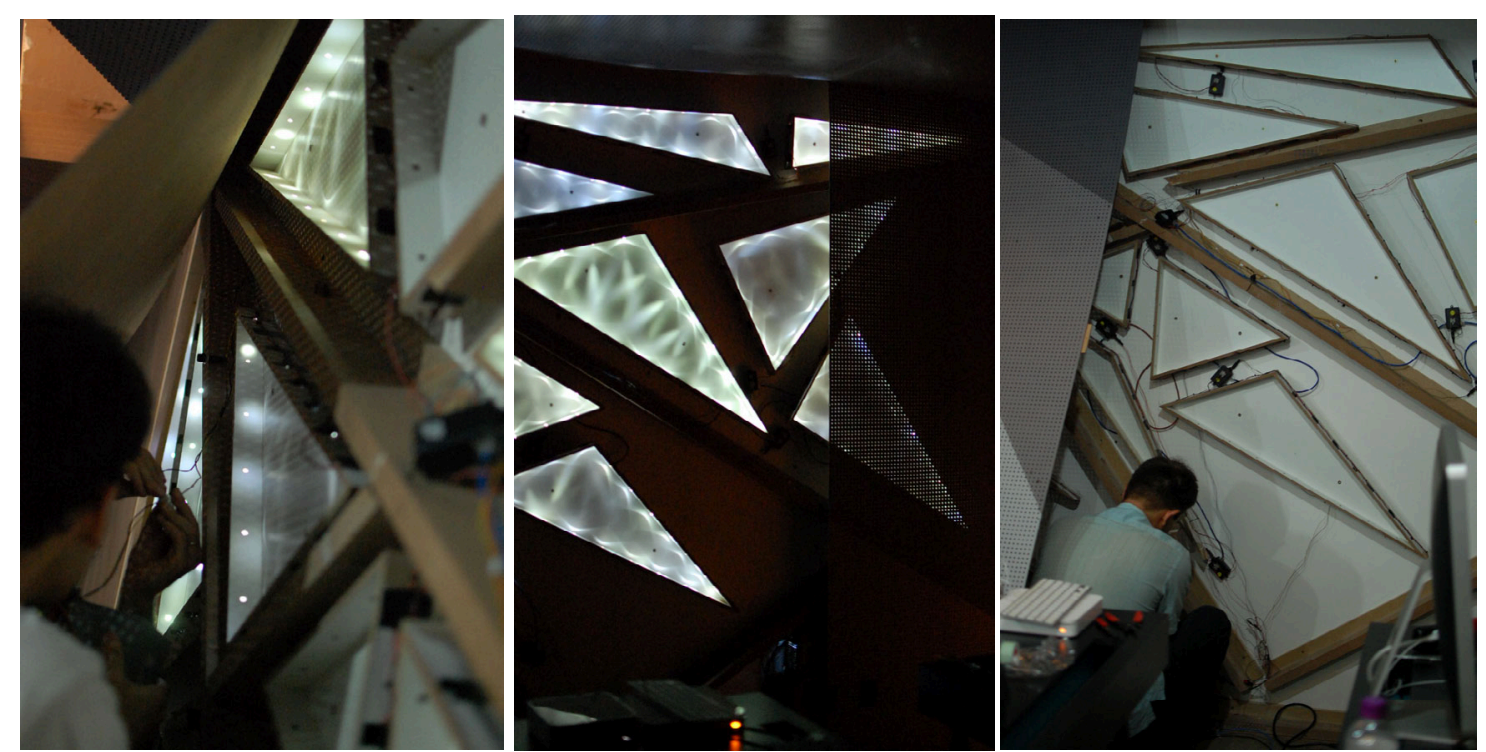

Figura 73-75: Ambiente Interativo D3 - montagem dos painéis e triângulos luminosos (Estúdio Guto Requena e i|o Design, 2011) (Fonte: Gabriela Ccarneiro)

Nesse caso, sistema interativo e arquitetura foram concebidos como uma só coisa, de forma a mesclar os recursos de diferentes linguagens. De um lado, foram instalados 
diversos sensores ultrassônicos no teto do espaço, um microfone na cozinha, e um sensor magnético para captar a abertura e fechamento da porta. De outro, 25 triângulos luminosos devolvem ao espaço o resultado da computação das informações captadas. Diferentes padrões luminosos foram elaborados para corresponder a usos específicos do espaço. Como se trata de uma área pequena, os triângulos foram instalados, atrás de um painel de madeira perfurado, o que diminui a incidência de luz no espaço, quando acionados (Figura 73-76).

A arquitetura, no caso do Ambiente Interativo D3, manteve-se na periferia da percepção das pessoas que ocupam o espaço. Segundo conta um dos diretores da empresa, um ano depois que o espaço passou a ser utilizado, seu sistema interativo ainda é diariamente acionado e, em nenhum momento, houve reclamações direcionadas aos efeitos luminosos. Sua dinâmica e responsividade são trazidas para o primeiro plano quando pessoas chegam ao espaço e, também, quando são realizados os experimentos criativos com as

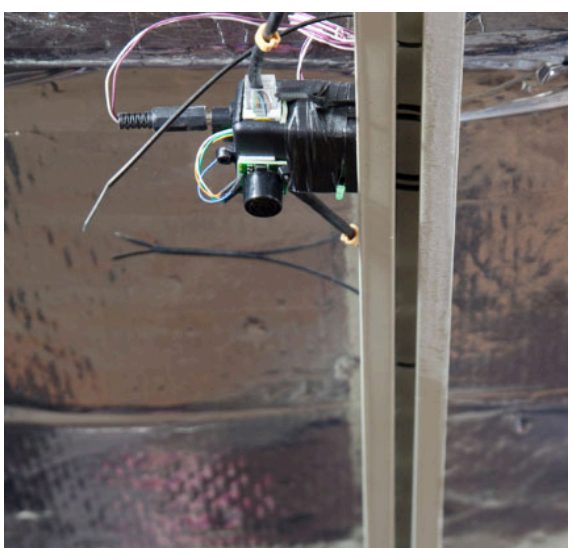

Figura 76: Sensores ultrassônicos - Ambiente Interativo D3. (Fonte: Fran Parente) possibilidades oferecidas pela arquitetura.

Assim sendo, seja por meio de sistemas de iluminação tradicionais ou derivados das tecnologias mais avançadas de display, seja por meio de estruturas genéricas ou customizadas, a exploração de efeitos luminosos dinâmicos deve ser entendida como uma estratégia de extrema importância para a materialização da arquitetura interativa. Oportunidades de exploração de suas possibilidades são abertas em diversos níveis. Arquitetos podem tanto se ocupar em criar módulos para serem reapropriados de maneiras inovadores, quanto inventar possibilidades customizadas, as quais questionam e mostram possibilidades de criação de espaços dinâmicos e interativos. Não se trata apenas da possibilidade de inserir conteúdos midiáticos na arquitetura, mas sim, aproveitar criativamente as possibilidades abertas pela tecnologia digital, de adicionar dinâmica e interatividade aos espaços.

As mesmas possibilidades podem, também, ser vislumbradas com a incorporação da cinética e do movimento de elementos físicos no espaço. O controle de motores e outros mecanismos, que dão suporte a adaptação, mobilidade e flexibilização da arquitetura, também indicam caminhos de grande relevância para a compreensão das diversas manifestações da arquitetura interativa. 


\subsubsection{Cinética}

A cinética, do grego kinetike é o "[...] ramo da física que estuda os movimentos"137. Na arte, no design e na arquitetura o termo é, normalmente, associado às obras que empregam o movimento como meio de expressão, seja por meio de estruturas físicas que se movem, ilusão de ótica ou mesmo posicionamento dos elementos que dão a impressão de movimento. Para esta pesquisa, interessam as iniciativas que utilizam cinética para a transformação física do espaço, fato que na arquitetura não é recente. Segundo Oungrinis (2007, p.1):

O design de espaços transformáveis não é uma idéia nova já que exemplos existem desde os tempos antigos. A sua aplicação generalizada, por outro lado, foi tornada impossível principalmente devido à falta de tecnologia necessária para uma estrutura cinética fácil de usar e fácil de manter. Nos últimos anos, muitos avanços tecnológicos abriram caminho em direção a soluções viáveis para elementos de construção transformáveis nas estruturas. 138

O movimento pode ser integrado no espaço por meio de diferentes estratégias. Em relação ao estilo empregado na transformação dos espaços, Oungrinis (2007) os classifica em sete tipos, alguns deles ilustrados na Figura 77. São eles: folding (dobraduras), scisor-type (tesoura), tensile (tensionamento), rolling/sliding (rolamento/ deslizamento), nesting (aninhamento), transergetic (sem tradução para o portugês) e pneumatic (pneumático).

Folding compreendem as soluções mais comuns e eficientes, já que "[...] existem infinitas maneiras de transformar um espaço interior ou exterior com a utilização de superfícies dobráveis, componentes lineares ou materiais flexíveis" ${ }^{139}$. Scisor-type e tensile são tipos de dobras, mas, dada suas especificidades, ocupam categorias distintas, sendo que a primeira consiste em uma "[...] ação de dobra complexa de elementos lineares que podem criar espaços expansíveis surpreendentes, governados

\footnotetext{
137 Definição extraída do Mini Larousse dicionário da lingual portuguesa, 2a Ed. São Paulo, Larousse do Brasil, 2008, p. 161.

138 Do original em inglês: The design of transformable spaces is not a novel idea since examples exist from the ancient times. Its widespread application though was rendered impossible mainly due to lack of the technology required for an easy-to-use and easy-to-maintain kinetic structure. In recent years, many technological breakthroughs have opened up the way towards viable solutions for transformable building elements within structures (OUNGRINIS, 2007, p.1).

139 Do original em inglês: there are infinite ways to transform an interior or exterior space by using folding surfaces, linear components or flexible materials (OUNGRINIS, 2007, p.3).
} 
por relações geométricas complexas" ${ }^{140}$; e a segunda, refere-se a tecidos ou malhas que podem ser dobradas e desdobradas. Rolling/sliding refere-se a superfícies deslizantes, nas quais são utilizados materiais de baixa fricção ou mesmo rolamentos. A expressão nesting é utilizada para designar aquelas soluções em que um conjunto de peças são concebidas para caber umas dentro das outras. Transergetic compreendem estruturas que utilizam uma complexa rede de elementos rígidos e elásticos para viabilizar sua transformação. E, por último, pneumatic são aqueles movimentos que utilizam ar comprimido como propulsor.
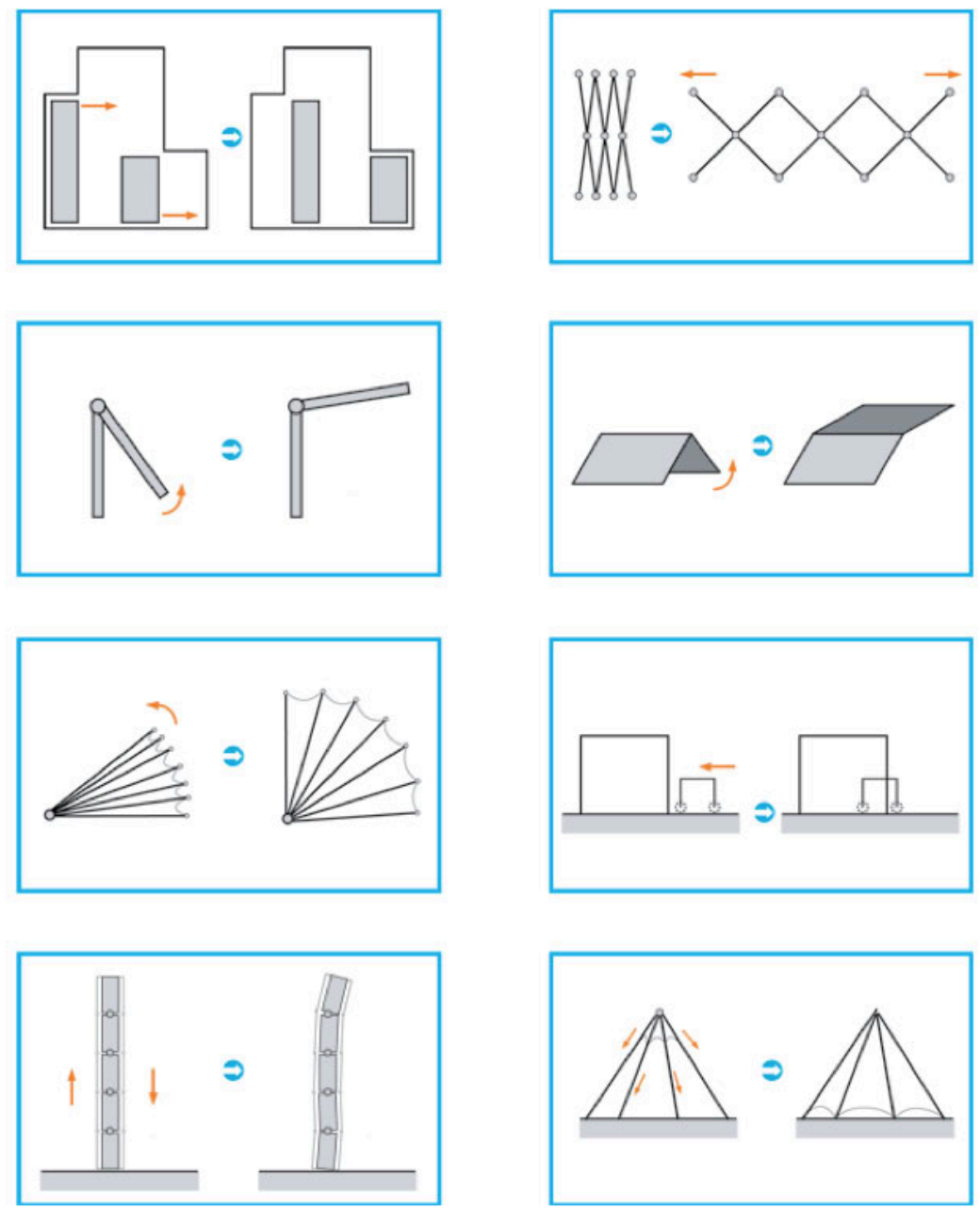

Figura 77: Diagramas

descrevendo alguns princípios do movimento mecânico (Fonte: OUNGRINIS, 2007, p.3)

Somadas às estratégias descritas, Fox e Kemp (2009) resumem os tipos de aplicação de estruturas cinéticas, especificamente na arquitetura, em quatro categorias gerais, quais sejam: utilização de elementos móveis na otimização espacial; design multifuncional; na adaptação ao contexto e mobilidade. Assim as descrevem os autores:

140 Do original em inglês: complex folding action of linear elements that can create surprisingly expanding spaces, governed by complex geometrical relations (OUNGRINIS, 2007, p.3). 
A cinética para sistemas de otimização especial são geralmente descritas como sistemas podem facilitar a adaptação espacial flexível. 0 design multifuncional se difere dos sistemas de otimização espacial porque estes sistemas fornecem especificamente os meios para uma pluralidade de estados otimizados que atendem a mudança no uso. Adicionalmente, a adaptação contextual é definida por como a cinética pode ser empregada em situações contextuais dinâmicas e desconhecidas. Por fim, olhamos para a cinética e mobilidade na qual a cinética serve como o meio evidente para a transportabilidade e instalação prática ${ }^{141}$ (FOX; KEMP, 2009, p.31).

Ainda segundo esses autores, estes sistemas podem ser introduzidos no espaço de três maneiras: como um sistema integrado, como um sistema desmontável e como uma estrutura dinâmica. O sistema integrado ocorre quando a estrutura cinética é parte integral do edifício, de forma que "[...] a função primária deste tipo de estrutura cinética é a de controlar o sistema arquitetônico maior ou o edifício, em resposta às mudanças ${ }^{\prime 142}$. Como exemplo, citam os edifícios com estruturas pneumáticas que minimizam impacto de terremotos.

Os sistemas desmontáveis são aqueles que "[...] caracteristicamente existem em um local temporário e são facilmente transportáveis. Essas estruturas cinéticas possuem a capacidade inerente de serem construídas e desconstruídas em reverso"143. Esses sistemas são utilizados, por exemplo, na criação de palcos para shows e espaços temporários de exposição (FOX; KEMP, 2009, p.47-48).

Já as estruturas dinâmicas, conforme Fox e Kemp (2009, p.47) são as mais comuns, “[...] elas são caracteristicamente sistemas menores dentro do edifício maior, mas não são necessariamente partes dele"144. Trata-se de elementos presentes como parte do espaço como um todo, porém com autonomia de funcionamento em relação à sua estrutura geral. "Sistemas elementares comuns tais como portas, janelas, elevadores e escadas rolantes podem ser considerados sistemas cinéticos dinâmicos. Nós podemos

\footnotetext{
141 Do original em inglês: The kinetics for spatial optimization systems are generally described as how systems can facilitate flexible spatial adaptability. Multifunction design differs from spatial optimization systems because these systems specifically provide the means for a plurality of optimized states to address changing use. Additionally, contextual adaptability is defined by how kinetics can be employed to dynamic or unknown contextual situations. Lastly, we look at kinetics and mobility whereby the kinetics serves as the obvious means for practical transportability and deployability ${ }^{141}$ (FOX; KEMP, 2009, p.31).

142 Do original em inglês: the primary function of this type of kinetic structures is to control the larger architectural system or building, in response to change(FOX; KEMP, 2009 p.47).

143 Do original em inglês: typically exist in a temporary location and are easily transportable. These kinetic structures possess the inherent capability to be constructed and deconstructed in reverse (FOX; KEMP, 2009, p.48).

144 Do original em inglês: they are typically smaller systems within the larger building, but they are not necessarily part of it(FOX; KEMP, 2009, p.47).
} 
expandir essa lista para incluir elementos menos comuns tais como camas dobráveis e outros elementos de mobiliário dinâmicos ${ }^{\prime 145}$ (p.47).

Somados aos meios descritos, diversas podem ser as motivações para a inserção do movimento no espaço construído. Entre elas, vale destacar a diferenciação entre intenções pragmáticas e humanistas (FOX; KEMP, 2009, p.30). As aplicações pragmáticas estão normalmente relacionadas à se necessidade de se resolver algum problema específico ou de se aperfeiçoar soluções. "As consequências gerais da utilização de tais sistemas na arquitectura incluem, mas não estão limitados a: eficiência de espaço, abrigo, estabilidade, transporte, a segurança, e, é claro, economia" ${ }^{146}$.

As questões humanísticas consideram "[...] como tais mudanças nos ambientes arquitetônicos nos afetam, tanto fisicamente quanto psicologicamente"147. Por um lado, são incluídas nessa perspectiva a exploração estética e formal enquanto investigação conceitual. Por outro, compreendem o ponto de vista da percepção de quem passa, habita e experiencia esses espaços. Uma intenção não exclui a outra, e a mistura destas motivações em diferentes graus é o que normalmente direciona a inserção da cinética na arquitetura.

Todo este contexto de transformação da arquitetura, por meio do movimento, é delineado para introduzir o ponto-chave desta pesquisa: quando a computação é introduzida nestes mecanismos de forma a possibilitar a programação destas estruturas. Ou seja, quando essas estruturas dinâmicas passam a responder dinamicamente à presença de pessoas, aos contextos, e às condições ambientais.

Ultimamente, a fusão de sistemas arquitetônicos cinéticos e tecnologia digital tem produzido uma arquitetura cinética digitalmente controlada, estruturas, ambientes ou componentes de construção capazes de modificar a forma, tamanho ou posição de sua forma física usando a integração de tecnologia computacional. Essa é uma visão de uma arquitetura tecnologicamente aperfeiçoada com capacidades "naturais" - ou seja, habilidades de sensoriamento e atuação, inteligência,

\footnotetext{
145 Do original em inglês: Common elemental systems such as doors, windows, elevators, and escalators can be considered dynamic kinetic systems. We can spand this list to include less-common elements such as pull-out shelving, pull-down stairs, folding beds, and other dynamic furniture elements(FOX; KEMP, 2009, p.47).

146 Do original em inglês: The general implications of utilizing such systems in architecture include, but are not limited to: space efficiency, shelter, security, transportation, safety, and, of course, economics (FOX; KEMP, 2009, p.30).

147 Do original em inglês: How such changes in our architectural environments actually affect us, both physically and psychologically (FOX; KEMP, 2009, p.30).
} 
movimento e comportamento proativo ${ }^{148}$ (YIANNOUDES, 2010, p.41).

Sistemas cinéticos dinâmicos colocam outros desafios e oportunidades, de forma que a combinação entre movimento, arquitetura e sistemas computacionais pode estender as possibilidades para muito além das soluções até, então, concebidas e construídas. Propostas podem tanto focar no desenvolvimento de estruturas altamente técnicas e especializadas, quanto na relação simbólica e simbiótica, entre pessoas e espaços. É o caso, por exemplo, do projeto Reciprocal Space (espaço recíproco), de 2005, desenvolvido por Ruairy Glynn (Figura 78) como crítica às soluções altamente avançadas, técnicas e industriais, tais como a Aegis Hyposurface, mencionada no Item 2.1.2.
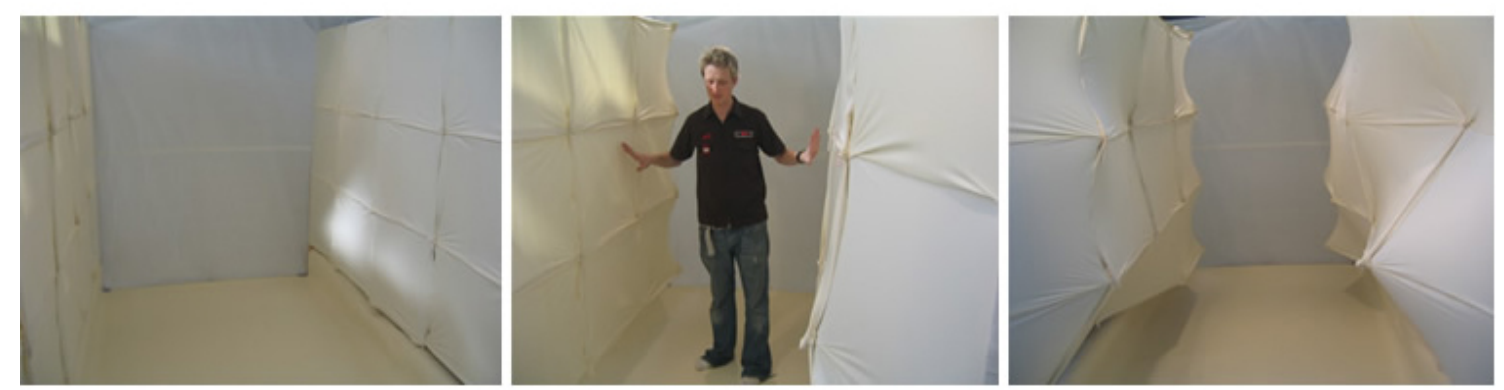

Figura 78: Reciprocal Space (Glynn, 2005) (Fonte: <http://www.ruairiglynn.co.uk> Acesso em: 10 Fev. 2013)

O projeto visava explorar mais a relação entre diferentes entidades, do que o controle eficiente de uma entidade por outra. O protótipo foi construído, utilizando motores de limpadores de vidro de carros, controlados com dados de sensores que captavam a presença de pessoas em sua proximidade. Glynn (2011, n.p.) diz que,

$\mathrm{Eu}$ tentei construir essa parede que possui uma resolução bem baixa, mexe-se bem devagar e é flexível. De certa maneira, você poderia entrar, ela poderia te tocar, criar os espaços a sua volta e responder aos seus movimentos. Assim, parte disso se torna um pouco parecido com um tipo de dança entre você e o ambiente. Se você fosse muito agressivo com o espaço ele poderia brigar de volta. Você teria que se envolver em uma espécie de negociação.

O projeto de Glynn aponta para outros sistemas de referências utilizados para a concepção de espaços. Trata-se da alteração de uma perspectiva determinista que entende os espaços e edifícios como máquinas, e na qual as mudanças são pensadas

\footnotetext{
148 Do original em inglês: Lately, the merging of kinetic architectural systems and digital technologies has produced digitally driven kinetic architecture, structures, environments or building components able to modify the shape, size or position of their physical form using embedded computational technology. This is a vision for technologically-enhanced architecture with 'naturalised' capacities - that is, sensing and actuation abilities, intelligence, motion and pro-active behaviour(YIANNOUDES, 2010, p.41)
} 
como cíclicas, com ações e reações, totalmente, previsíveis e mapeáveis. Diferentemente, referências orgânicas abordam o espaço, a partir de modelos adaptáveis, no qual impera a imprevisibilidade e probabilidade. "A hegemonia de sistemas orgânicos contra as teorias dos sistemas mecânicos alterou o modelo conceitual que aplicamos para entender nosso ambiente e, consequentemente, projetar nosso ambiente"149 (FOX; KEMP, 2009, p.49). Nesse contexto, questões relacionadas à biomimética e robótica modular têm inspirado cada dia a criação da arquitetura interativa, em especial as soluções que envolvem estruturas cinéticas dinâmicas.

A biomimética pode ser entendida como um tipo de design inspirado pelos sistemas biológicos. É um campo do conhecimento multidisciplinar que une saberes advindos da biologia, engenharia, design e computação. Como Zuk (1970, p.14) coloca, estas investigações a partir das soluções da natureza são feitas não com o intuito de copiálas, e sim "[...] para obter insights sobre eles e uma apreciação para estes mecanismos orgânicos e como eles tornam possível formas superiores de vida capazes de serem mais que apenas elementos passivos" ${ }^{150}$. Nesse sentido, a biomimética nutre a base para a elaboração de uma "[...] arquitetura fisicamente dinâmica que surge das necessidades humanas e é sustentada por um melhor entendimento dos sistemas biológicos"151 (FOX; KEMP, 2009, p. 237).

De acordo com Fox e Kemp (2009, p.230) a robótica modular é uma perspectiva na qual, no lugar de pensar em robôs humanóides, o foco é no desenvolvimento de sistemas transformáveis compostos por robôs menores, ou seja, "robôs feitos de partes modulares que funcionam como um sistema para interpretar e agir à informação" ${ }^{152}$. O contato com essa perspectiva inspirou o Fox a propor o redesenho do tijolo, ou seja, a releitura dos elementos básicos da arquitetura sob a ótica da robótica modular.

Avanços atuais nos robôs metamórficos, evolucionários, e automontáveis, que lidam especificamente com a escala dos blocos de construção, e a quantidade de inteligência responsiva que pode

\footnotetext{
149 Do original em inglês: The prevalence of organic systems over machine systems theory has altered the conceptual model that we apply in order to comprehend our environment and, consequently, design our environment (FOX; KEMP, 2009, p.49)

150 Do original em inglês: [...] to gain insight into and an appreciation for these organic mechanisms and how they make possible higher life forms capable of being more than just passive elements (ZUK, 1970, p.14).

151 Do original em inglês: physically dynamic architecture that arises out of human needs and that is supported by an improved understanding of biological systems(FOX; KEMP, 2009, p.237).

152 Do original em inglês: robots made up of modular parts that work as a system to interpret and act upon information (FOX; KEMP, 2009, p.230).
} 
ser introduzida nestes módulos, estão estabelecendo novos padrões para a construção robótica153 (FOX; KEMP, 2009, p. 382).

A aplicação destas possibilidades na criação de espaços responsivos tem aberto novos caminhos para arquitetura interativa, e o papel do arquiteto, a cada dia mais, será justamente a criação destas unidades e como elas se relacionam.

Uma vez que será possível construir um espaço com peças que possuem a habilidade de se reconfigurar, caberá aos arquitetos e designers projetar como estas peças se unirão e como estas configurações irão responder ao fluxo constante de informações entre o habitante e o espaço.154 (FOX; KEMP, 2009, p. 384).

No contexto abordado por esta pesquisa, a cinética é introduzida para ilustrar caminhos por onde passam as experimentações que utilizam a computação para introduzir movimento e dinâmica nos elementos dos espaços construídos. Estas questões buscam apresentar a base interdisciplinar que permeia a arquitetura interativa e não devem ser entendidas como fatores delimitadores do campo, mas sim, como alguns dos possíveis pontos de entrada para esta investigação.

Deste modo, componentes, materiais inteligentes, iluminação dinâmica e cinética podem ser considerados os principais elementos estruturais que viabilizam a materialização da arquitetura interativa. A análise desses aspectos possibilita o entendimento dos diferentes elementos que constituem esse tipo de espaço. Sensores e atuadores podem, em um extremo, ser componentes genéricos espalhados no espaço, e, no outro extremo, totalmente customizados na forma de elementos tradicionais da arquitetura. Uma vez que a arquitetura interativa pressupõe o tratamento lógico dessas informações, torna-se imperativo o entendimento de alguns princípios que determinam o comportamento desses ambientes.

\subsection{Comportamento}

Para complementar o entendimento do objeto de estudo desta pesquisa, resta abordar a questão de seu comportamento. Da maneira como é tratada neste trabalho, a arquitetura interativa pressupõe a inserção de sistemas computacionais em sua estrutura, assim, em um primeiro momento, falar de seu comportamento implica o 
entendimento deste sistema. Neste caso, seu comportamento é resultado do tipo de algoritmo que é implementado em seu núcleo processador. Por outro lado, entendese, como relevante, os diversos modelos de interação que podem emergir das relações dinâmicas que o sistema computacional, embarcado nos espaços, estabelece com seu contexto, ou seja, é também importante estabelecer um entendimento holístico de seu comportamento.

Duas perspectivas complementares auxiliam na compreensão do comportamento da arquitetura interativa. A perspectiva, aqui colocada, compreende tanto o entendimento das partes e como estas se relacionam, quanto a abordagem do edifício interagindo com seu contexto. Por um lado, pode ser identificada um lógica interna que diz respeito aos algoritmos implementados, por meio da programação. Por outro, essa lógica faz parte de um todo maior e a coerência externa indica como o sistema interage com seu contexto e com quais elementos interage diretamente. Essa estrutura de entendimento baseia-se em uma reflexão proposta por Alexander (1968) que diferencia dois tipos complementares de sistemas, o holístico (system as a whole) e o gerador (generating system). Segundo o autor,

Esses dois pontos de vista, embora superficialmente semelhantes, são logicamente muito diferentes. No primeiro caso, a palavra "sistema" se refere a uma visão holística particular de uma única coisa. No segundo caso, a palavra "sistema" não se refere a uma única coisa, mas a um kit de peças e regras combinatórias capaz de gerar muitas coisas ${ }^{155}$ (ALEXANDER, 1968, p.59).

A proximidade do que é aqui apresentado como lógica interna, com o que Alexander (1968, p.65) define como sistemas geradores, reside no fato de que, para entender o comportamento de uma arquitetura interativa em seu contexto (sua coerência externa), primeiramente é necessário desvendar os princípios básicos das interações possíveis. Segundo o autor "[...] quase todo 'sistema holístico' é gerado por um sistema gerador. Se nós quisermos fazer coisas que funcionam como um todo nós temos que inventar sistemas geradores para criá-las"156. A forma como estas interações e os níveis de complexidade que o comportamento de uma arquitetura interativa pode alcançar, depende então da maneira como as regras de manipulação destes elementos simples são criadas.

\footnotetext{
155 Do original em inglês: These two views, though superficially similar, are logically quite different. In the first case the word 'system' refers to a particular holistic view of a single thing. In the second case, the word 'system' does not refer to a single thing at all, but to a kit of parts and combinatory rules capable of generating many things (ALEXANDER, 1968, p.59).

156 Do original em inglês: almost every 'system as a whole' is generated by a generating system. If we whish to make things which functions as wholes we shall have to invent generating systems to create them (ALEXANDER, 1968, p.65).
} 
Um paralelo também pode ser feito com os sistemas construtivos, que, segundo o autor, "[...] um sistema construtivo [também] é um sistema gerador neste sentido. Ele fornece um kit de partes - colunas, vigas, painéis, janelas, portas - que devem ser conectadas de acordo com regras específicas"157 (ALEXANDER, 1968, p.65). Se em ambos os casos, a base da construção pode ser considerada um sistema gerador, o que define o resultado que emerge deste sistema são tanto os parâmetros elencados para a configuração do sistema quanto a intenção maior que ele representa. Neste sentido, entendimentos holísticos da interação dos espaços interativos com seu contexto são abordados, neste trabalho, de acordo com os modelos que representam. Ambas perspectivas, interna/geradora e externa/holística requerem aproximações específicas, que serão tratadas, a seguir. Essa abordagem propõe uma estrutura que busca esclarecer a que se referem as discussões sobre o comportamento da arquitetura interativa.

\subsubsection{Lógica interna}

A partir da abordagem proposta por esta pesquisa, a lógica interna da arquitetura interativa é composta pelos blocos geradores da tecnologia digital, que fundamentalmente trata-se da manipulação de zero ou um. Nesse sentido, no que se refere à programação, por mais complexo que um comportamento possa parecer, em sua estrutura mais básica, tudo é pré-definido, inclusive o espaço para o inesperado ou para o aprendizado. Para que um computador funcione, todas as ações são descritas previamente, de forma que não há lugar para a ambiguidade. A elaboração de um algoritmo, neste sentido, consiste basicamente na descrição de possibilidades de relações.

A compreensão do funcionamento de um microcontrolador esclarece com propriedade esse ponto. Em síntese, um microcontrolador é um tipo de computador, pois possui, em sua estrutura básica, os mesmos elementos de um computador pessoal tradicional. A principal diferença é que o microcontrolador concentra todos esses elementos em um único circuito integrado.

Por se tratar de um pequeno computador completo, os microcontroladores são utilizados para incorporar a computação nos mais diversos objetos, estruturas e

157 Do original em inglês: a building system is a generating system in this sense. It provides a kit of parts columns, beams, panels, windows, doors - which must be put together according to certain rules (ALEXANDER, 1968, p.65). 
espaços. Diferentes tipos de microcontroladores são utilizados, dependendo da necessidade da aplicação, da memórica necessária e dos componentes que serão adicionados. Essa especificidade reduz, significativamente, seu custo e contribui para sua disseminação.

Um microcontrolador é um chip genérico que pode ser programado, ou seja, os componentes básicos que direcionam, logicamente, a passagem dos pulsos elétricos são passíveis de serem reorganizados. Alguns podem ser programados uma única vez e, dado seu baixo custo, são utilizados uma vez que o desenvolvimento do sistema é concluído e parte-se para a produção em massa de determinado produto. Outros podem ser constantemente reprogramados e são, normalmente, utilizados para desenvolver e testar as aplicações, ou também para instalações e projetos temporários.

De forma simplificada, a função de um microcontrolador é conectar os inputs aos outputs, e adicionar, entre eles, os procedimentos implementados. 0 microcontrolador possui diversos pinos, de forma que cada um possui funções específicas, ou alternativas de funções, que devem ser especificadas na programação. Um dos microcontroladores utilizado pela plataforma Arduino, por exemplo, é o Atmega328P, um chip reprogamável que possui 28 pinos para entrada e/ou saída de dados, como ilustrado na Figura 79.

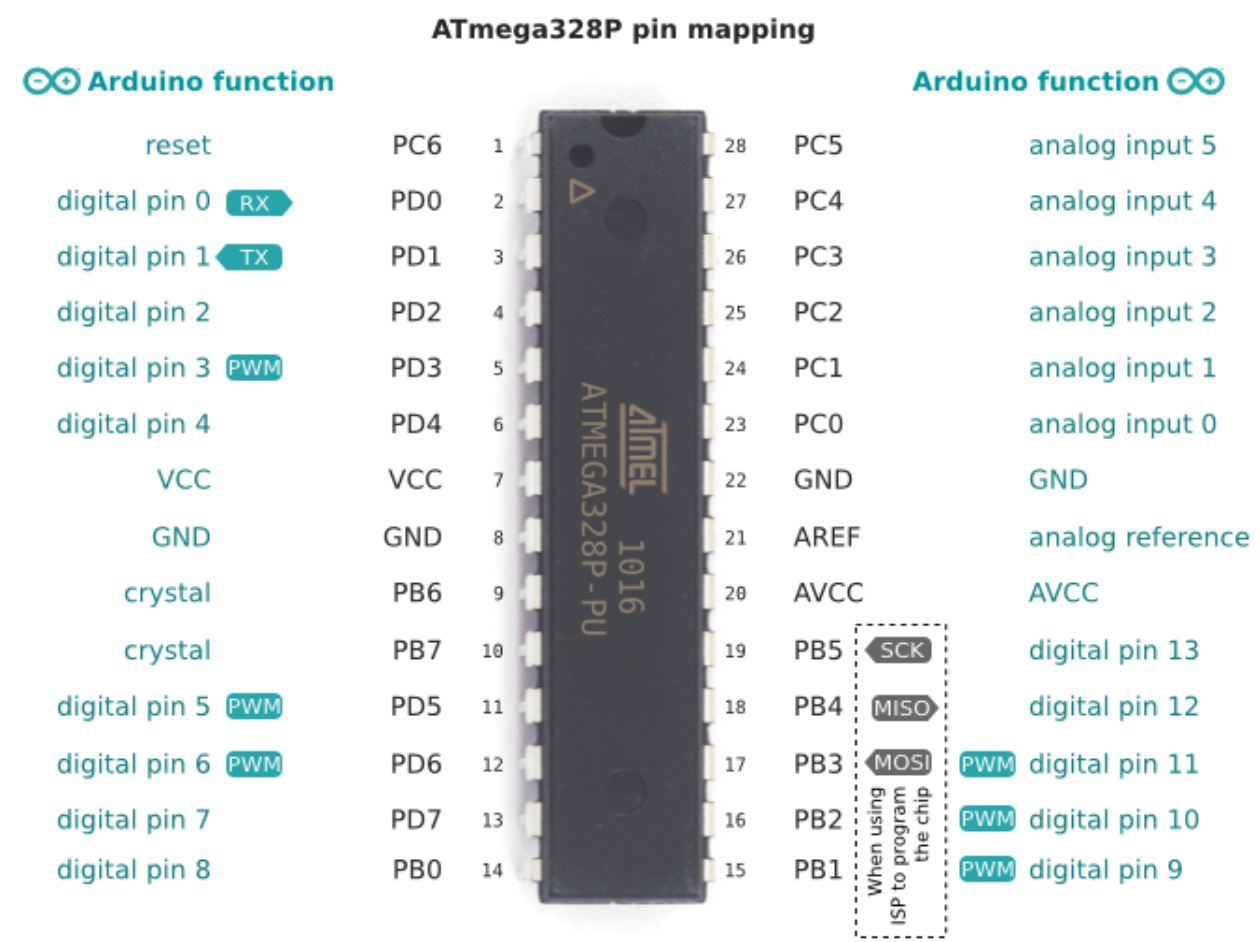

Figura 79: Mapeamento dos pinos do microcontrolador Atmega328P (Fonte: <http://www.arduino.cc> Acesso em: 10 Fev. 2013) 
Dentre os pinos do microcontrolador Atmega328P, seis são utilizados para receber variação de energia (input analógico), 14 podem receber ou emitir energia (input ou output digital), e, dentre esses 14 , seis podem simular uma emissão variada de energia (output analógico - PWM) e dois podem ser utilizados para comunicação (envio e recebimento de protocolos de comunicação $-r x$ e tx). Os outros sete pinos desempenham outras funções, tais como alimentação de energia (GND e VCC) e ritmação dos pulsos elétricos (cristal clock).

Definir a função de cada pino entre as possibilidades disponíveis, estabelecer quais pinos serão utilizados e descrever o que acontece com a informação recebida são as principais funções da programação em um microcontrolador. No projeto Affective Twins (CARNEIRO, 2008), ilustrado na Figura 80-82, a lógica interna dos dois objetos é bastante simples e elucida algumas possibilidades. Trata-se de dois cubos, ambos com sensores de toque em sua superfície (inputs digitais), e com luzes que variam sua intensidade luminosa (output analógico) e motores vibratórios que ligam e desligam em seu interior (outputs digitais). A informação de toque ou não-toque, de cada um, é enviada para o outro por rádio-frequência ( $r x$ e $t x$ ), e a combinação de toque e/ou nãotoque em cada um estimula quatro possíveis comportamentos.
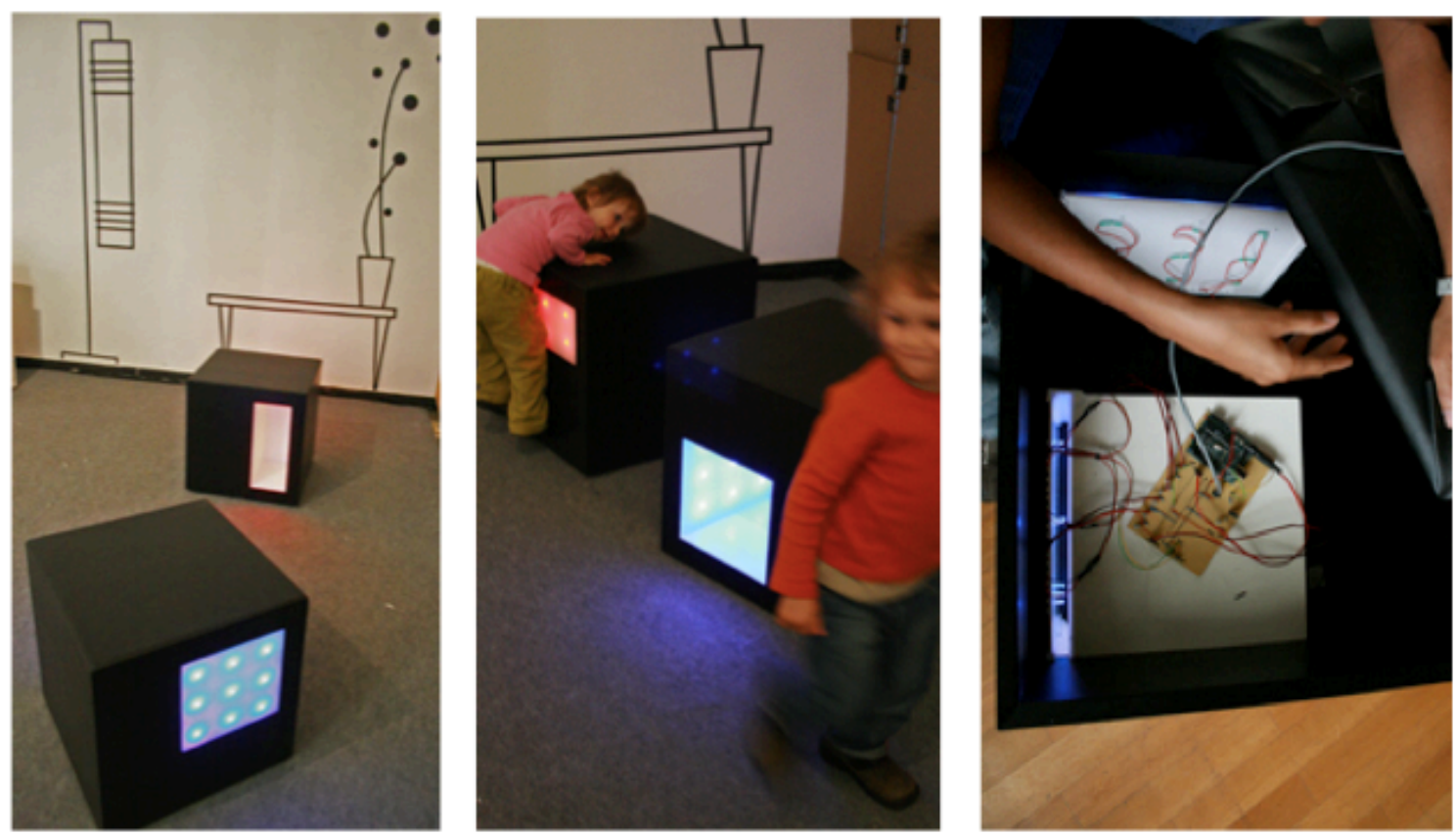

Figura 80-82: Mobiliário interativo Affective Twins (2008) (Fonte: Gabriela Carneiro, 2008)

O comportamento dos Affective Twins é um exemplo básico do que é possível. Ilustra as possibilidades que se abrem uma vez que algoritmos e funções lógicas são passíveis de serem implementadas, de forma a alterar a relação direta entre input e output e, conseqüentemente, o comportamento do sistema. Input e output, nas suas formas analógicas e digitais, podem ser, assim considerados os quatro canais básicos de troca 
de informações, que conectam a lógica interna de um sistema digital ao mundo exterior. A partir daí, outras relações, com inúmeros níveis de complexidade, podem ser elaboradas por meio dos al goritmos, de forma a enriquecer a interação entre o sistema digital e seu contexto.
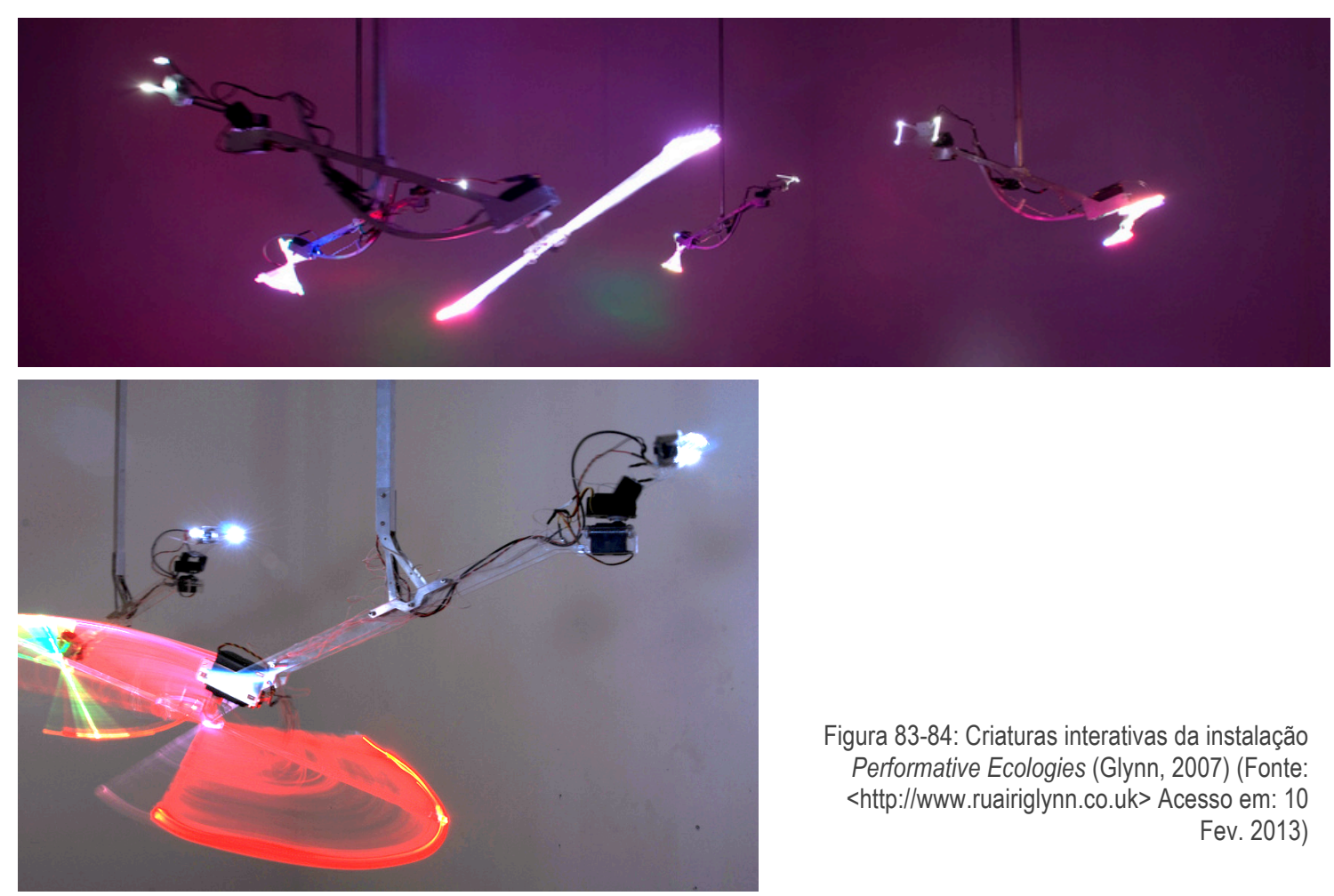

Figura 83-84: Criaturas interativas da instalação Performative Ecologies (Glynn, 2007) (Fonte: <http://www.ruairiglynn.co.uk> Acesso em: 10

Fev. 2013)

Explorar essas lógicas comportamentais mais complexas foi, por exemplo, a intenção de Glynn (2011), descrita a seguir, ao desenvolver sua obra Performative Ecologies (Figura 83-84):

$\mathrm{Eu}$ queria construir uma máquina que desenvolvesse seus próprios gestos, que fosse capaz de distinguir quais tipos de gestos fazem mais sucesso e que aprendesse a partir daí. (...) Então, eu criei essas criaturas que se parecem com animais, com rabos de luz, com câmeras em suas cabeças, e as câmeras eram capazes de reconhecer as pessoas. Portanto, os robôs foram trazidos ao mundo, pelo menos inicialmente com um comportamento totalmente randômico, com suas limns acenando para todos os lados. Mas eles tinham este instinto, esse objetivo de atrair a atenção. Assim, quanto mais conseguiam, ou sempre que conseguiam, eles entendiam que 'isso funciona, então vou guardar isso, e isso não funciona então vou descartar'. Essencialmente o algoritmo que usei para fazer isso foi um algoritmo genético, e existem diversas maneira que você pode fazer isso"158.

158 Do original em inglês: I wanted to build a machine that would evolve it's own gestures, be able to somehow tell what kinds of gestures are the most successful and learn from that. [...] So I built these animal-like creatures with these tales of light, which had cameras in their heads, and the cameras could do facial recognition. So, the robots 
Por mais que termos, tais como aprendizado e reconhecimento, sejam utilizados para descrever o sistema interativo desta obra, é importante compreender que até mesmo o randômico é programado. Existe uma função, uma equação matemática, responsável por gerar números randôminos em cada ciclo - em cada iteração. Por trás de todo discurso relacionado à lógica interna de um sistema digital, existem equações, variáveis e funções específicas bem definidas que são implementadas no núcleo do sistema controlador. Todo número ocupa um espaço, na memória, e esse espaço precisa necessariamente ser definido e dimensionado. Até mesmo a criação de novas funções são previamente previstas, por mais que uma ampla gama de possibilidades possa ocorrer. É por este motivo, que um algoritmo não aceita ambiguidade, e que o computador só é capaz de decidir, aprender e reconhecer padrões previamente antecipados.

A partir da manipulação desses elementos básicos e da lógica implementada, é possível caracterizar diferentes sistemas. Dubberly, Pangaro e Haque (2009, p.72), por exemplo, elencam três tipos essenciais de sistemas dinâmicos (Figura 85), ou seja, "[...] aqueles que podem e agem, mudando assim sua relação com o ambiente"159 (p. 71). São eles: os lineares (linear systems), os auto-reguladores (self-regulating systems) e de aprendizado (learning systems), de forma que sua diferença reside no tipo de rotina lógica implementada.
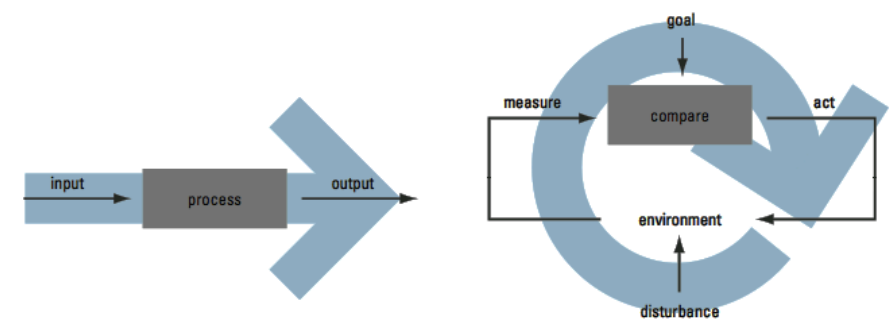

Linear System
Auto-regulating System

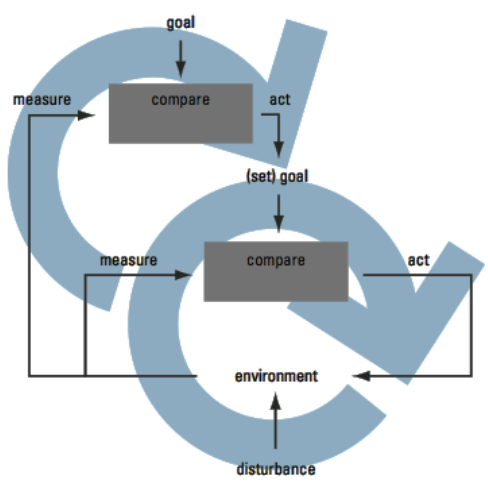

Learning System

Figura 85: Três tipos de sistemas dinâmicos elencados para gerar as interações.

(Fonte: Imagens adaptadas de Dubberly, Pangaro e Haque (2009), por Gabriela Carneiro)

were born into the world, at least initially behaving completely randomly, with their limns just waving around but they have this instinct, this goal to attract attention. So, as they became more successful, whenever they were successful they would go 'that works, so I'm going to keep that, and this didn't work so I'm going to leave it behind'. And essentially the algorithm that I used to do it was a genetic algorithm, there's various different ways you can do that (GLYNN, 2010).

159 Do original em inglês: those that can and do act, thus changing their relationship to the environment (DUBBERLY; PANGARO; HAQUE, 2009, p.71). 
Assim, os sistemas lineares apenas respondem a estímulos com respostas padrões; os auto-reguladores comparam, a cada momento, o tipo de informação captada por seus sensores com seu objetivo para, então, ajustar sua trajetória, que varia sua resposta para manter certo equilíbrio; e os de aprendizado que, além de adequar sua trajetória, aprendem com as mudanças e podem alterar tanto o tipo de resposta quanto seus próprios objetivos. Estas características podem ser notadas separadamente ou combinadas, de forma que um mesmo sistema pode responder linearmente a certos estímulos e ao mesmo tempo aprender com aquela informação para alterar a resposta em uma próxima iteração.

Nesse sentido, a interação ocorre, quando dois sistemas passam a trocar informações e um influencia o comportamento do outro. Dois sistemas dinâmicos podem interagir entre si, da mesma maneira que a interação pode ocorrer com o ambiente ou com pessoas. Com o objetivo de tornar a questão da interação conceitualmente manipulável, Dubberly, Pangaro e Haque (2009) elencaram diferentes modelos de interação, partindo da combinação de dois sistemas dinâmicos. Com os sistemas lineares, auto-reguladores e aprendizado, foram formadas todas as combinações de duplas possíveis para elencar diferentes tipos de interação. Com isso, seis tipos de interações foram geradas, analisadas e exemplificadas (Figura 86).

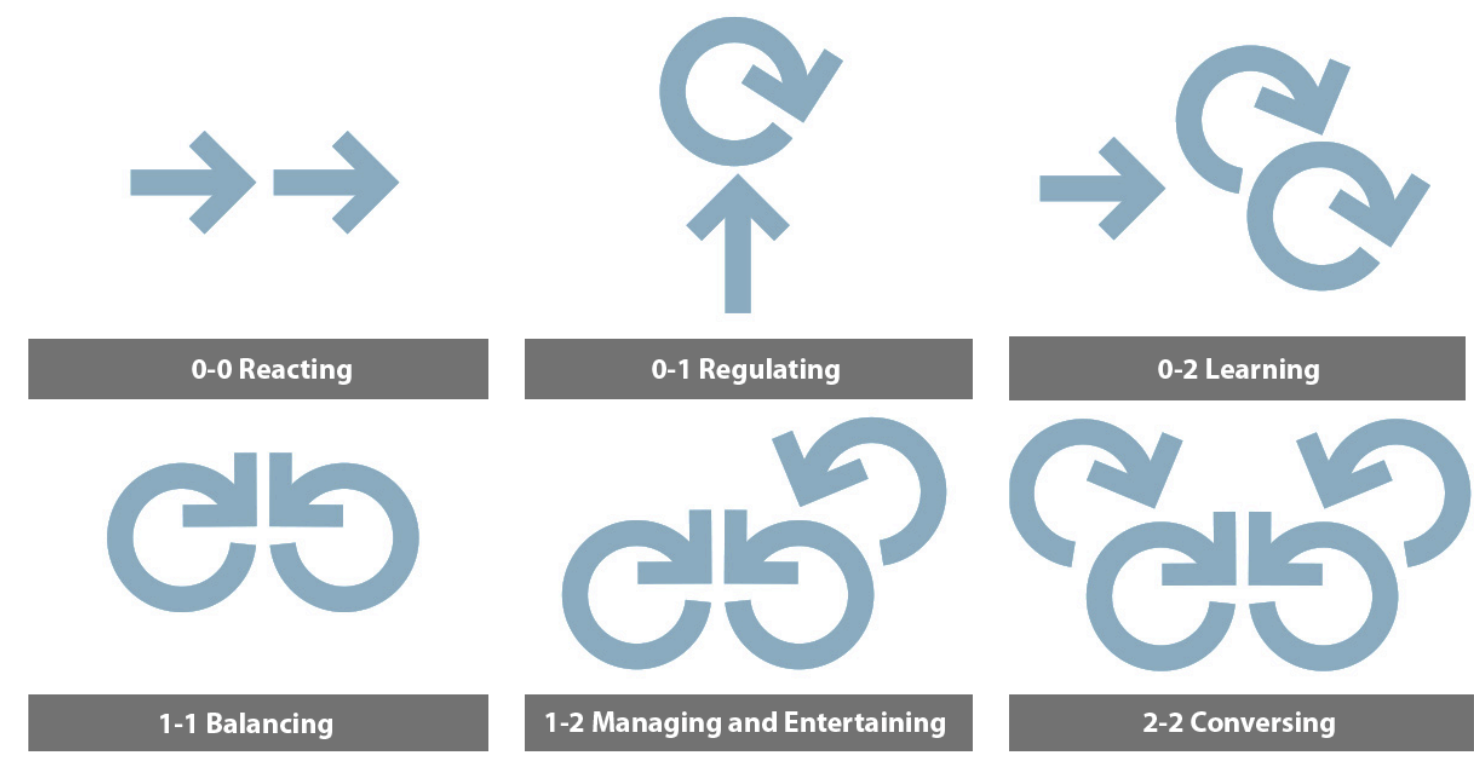

Figura 86: Os seis tipos de interação gerados pelo agrupamento, em duplas, dos sistemas

(Fonte: Imagens adaptadas de Dubberly, Pangaro e Haque (2009), por Gabriela Carneiro)

$\mathrm{Na}$ interação reativa (reacting) - formada por dois sistemas lineares - "[...] uma ação causa uma reação. O primeiro sistema impulsiona o segundo. O segundo sistema não possui escolha de resposta. De certa maneira, os dois sistemas lineares funcionam 
como um só"160 (DUBBERLY; PANGARO; HAQUE, 2009, p.73). Um exemplo seria um sensor de porta que capta o sinal de uma pessoa se aproximando-se e, com isso, aciona um motor que abre a porta.

A interação é reguladora (regulator), com a combinação de um sistema linear e outro auto-regulador. Nesse caso, "[...] o output de um sistema linear fornece um input para um sistema auto-regulador" ${ }^{\prime 161}$ (DUBBERLY; PANGARO; HAQUE, 2009, p.73). Um exemplo é o sistema de um termostato, que controla a passagem de energia para um aquecedor com o objetivo de manter sempre a mesma temperatura, no ambiente.

$\mathrm{Na}$ interação de aprendizado (learning) - formada por um sistema linear e outro de aprendizado - quando um sistema de aprendizado interage com um sistema linear. Tal coisa acontece, por exemplo, no modo como a relação com os softwares são, normalmente, concebidas. Se considerarem-se as pessoas como sistemas de aprendizado, "[...] você (o sistema de aprendizado) aciona seu computador (o processo linear simples); ele responde; você reage. Depois de acionar seu computador vezes suficientes, você desenvolve um modelo de como ele funciona. Você aprende o sistema. Mas ele não aprende você"162 (DUBBERLY; PANGARO; HAQUE, 2009, p.73).

Uma interação de balanceamento (balancing), combina dois sistemas autoreguladores. Nela, a relação entre eles pode assumir duas características: reforço ou concorrência. "Sistemas reforçadores dividem os mesmos objetivos (com atuadores que podem ou não funcionar da mesma maneira) [...] sistemas concorrentes possuem objetivos concorrentes" (DUBBERLY; PANGARO; HAQUE, 2009, p.73). Um exemplo do primeiro são dois aparelhos de ar condicionados em um mesmo ambiente, ambos cooperam para manter a mesma temperatura. Os sistemas concorrentes buscam manter um equilíbrio e podem ser observados em sistemas econômicos, tal como a lei da oferta e da procura.

Uma interação gerenciadora ou de entretenimento (managing \& entertainment), combina um sistema auto-regulador, com um de aprendizado. Quando isso acontece, dois resultados são possíveis. O primeiro diz respeito ao gerenciamento de sistemas

\footnotetext{
160 Do original em inglês: Action causes reaction. The first system pushes the second. The second system has no choice in its response. In a sense, the two linear systems function as one (DUBBERLY; PANGARO; HAQUE, 2009, p.73).

161 Do original em inglês: The output of a linear system provides input for a self-regulating system (DUBBERLY; PANGARO; HAQUE, 2009, p.73).

162 Do original em inglês: You (the learning system) signal your computer (the simple linear process); it responds; you react. After signaling the computer enough times, you develop a model of how it works. You learn the system. But it does not learn you. (DUBBERLY; PANGARO; HAQUE, 2009, p.74).
} 
automáticos, por exemplo, um piloto (sistema de aprendizado), manipulando o objetivo do piloto-automático (auto-regulador). O segundo resultado pode ser o entendimento como entretenimento, ou seja, quando o objetivo do sistema autoregulador é manter o envolvimento do sistema de aprendizado. Isso acontece, por exemplo, em jogos, nos quais “[...] muitas vezes, o objetivo do aplicativo é manter o interesse dos usuários, por exemplo, aumentado a dificuldade na medida em que o jogador melhora sua habilidade ou introduzindo surpresas quando a atividade diminui, provocando a renovação da atividade." ${ }^{163}$ (DUBBERLY; PANGARO; HAQUE, 2009, p.74)

Com dois sistemas de aprendizado, a ação de cada sistema é sempre resultado de entendimentos e assemelha-se a uma conversa entre duas pessoas. Essa interação é assim descrita pelos autores:

Esse tipo de interação é como uma conversação cara a cara (peerto-peer) na qual cada sistema aciona o outro, talvez fazendo perguntas ou executando comandos (com a esperança, mas sem a certeza de resposta), mas existe um espaço para escolha na parte do respondente. Além disso, os sistemas aprendem um com o outro, não apenas descobrindo quais ações podem manter seus objetivos em circunstâncias específicas (...) mas por meio da troca de informação de interesse mutuo. Eles podem coordenar objetivos e ações. Nós podemos dizer que eles até são capazes de design - de concordar sobre objetivos e meios de alcançá-los. ${ }^{164}$ (DUBBERLY; PANGARO; HAQUE, 2009, p.75)

Esta modelagem dos diferentes tipos de interação proposta por esses estudiosos, certamente possui suas limitações, os próprios autores comentam e exemplificam, no texto, como um refinamento pode levar a outros tipos mais sutis de interações. Entretanto, ela é inteiramente válida, se entendida como um modelo, ou seja, uma representação simplificada de um fenômeno real, normalmente, utilizada para extrair sentido de fenômenos, cuja elevada complexidade dificulta a explicação e o entendimento de sua dinâmica (MITCHEL, 2009, p.209-210). Vale lembrar que esta não é uma medida fixa, ou seja, mesmo sistemas extremamente simples podem criar complexidade ao interagir com outros sistemas.

\footnotetext{
163 Do original em inglês: Often the application's goal is to keep users engaged, for example, increasing difficulty as player skill increases or introducing surprises as activity falls, provoking renewed activity (DUBBERLY; PANGARO; HAQUE, 2009, p.74).

164 Do original em inglês: This type of interaction is a like a peer-to-peer conversation in which each system signals the other, perhaps asking questions or making commands (in hope, but without certainty, of response), but there is room for choice on the respondent's part. Furthermore, the systems learn from each other, not just by discovering which actions can maintain their goals under specific circumstances (as with a standalone secondorder system) but by exchanging information of common interest. They may coordinate goals and actions. We might even say they are capable of design - of agreeing on goals and means of achieving them (DUBBERLY; PANGARO; HAQUE, 2009, p.75).
} 
Para esta pesquisa, este modelo mostra-se suficiente para ilustrar um possível modo de entendimento simplificado dos tipos de interações que espaços podem estabelecer com seu contexto. Por mais que diferentes tipos de interação possam ser elencados e utilizados, para compor conceitualmente um sistema, seu significado e qualidade estão relacionados não com a complexidade do algoritmo implementado. Relacionam-se, sim, com sua inserção em um contexto maior, ou seja, com sua coerência externa, questão na qual aspectos diferentes daqueles relacionados à lógica interna passam a ser relevantes.

\subsubsection{Coerência externa}

Como mencionado, inputs e outputs, junto com os diferentes comportamentos implementados, compreendem a lógica interna da arquitetura interativa, ou seja, configuram seu sistema gerador. Por outro lado, em seu entendimento enquanto sistema holístico, as regras, a previsão e a antecipação tornam-se questões secundárias, e o importante passa a ser tanto o significado de determinado sistema dentro de um contexto maior, como as intenções que determinam sua configuração.

Nessa perspectiva, algoritmos, altamente complexos, não resultam em melhores interações, de forma que as possibilidades interativas passam a ser compreendidas como ferramentas que podem ser utilizadas para expressar ideias e modelos de mundo. Como aponta Sauter (2010),

Interatividade e reatividade não são interessantes, elas são uma espécie de ferramenta para criar o interessante. Sabe, se você tem um piano mas não consegue tocá-lo apropriadamente, as pessoas não irão querer escutar sua música. Assim, diferentes tipos desses, digamos, estados, estado de auto-ativação se algo acontece sem intervenção de uma pessoa, reativo que é a intervenção não intencional e interativo que é o diálogo intencional com algo, são apenas cores para um pintor. Se tenho que fazer algo com um tipo de conteúdo, pode ser totalmente significativo usar a interatividade, e então, com outro tipo de conteúdo é melhor uma instalação auto-ativada. Portanto, trata-se apenas de uma escolha de design. ${ }^{165}$

\footnotetext{
165 Do original em inglês: Interactivity and reactivity are not interesting, they are more or less tools to create that. You know this is your piano and if you can't play it properly people don't want to listen to your music. So, different kind of these, let's say, states, state of auto-active if something is running without any intervention from person, reactivity which is the unintentional and interactivity which is the intentional dialogue with something. These are only colors to a painter. If I have to do something there, with this kind of content, it's totally meaningful to use interactivity and then in another content is an auto-active installation. So it's only the choice of the design (SAUTER, 2010).
} 
Uma arquitetura interativa, por exemplo, pode ser criada com o intuito de economizar recursos naturais e otimizar o consumo energético. Trata-se da aplicação de um modelo holístico bastante utilizado, no qual os edifícios interativos são vinculados a noções de sustentabilidade. Segundo Fox e Kemp (2009, p.109),

Um edifício interativo pode dinamicamente mitigar condições para tirar vantagem de estratégias de conservação de energia, tais como a orientação do edifício e das aberturas para maximizar as oportunidades de iluminação natural e ganho de calor solar desejado, evitando o ganho de calor solar indesejado, perda de calor e térmica devido à infiltração de vento, assim como maximizar oportunidades passivas de insolação e refrigeração"166 (p.109)

A partir dessa intenção inicial, decisões de design serão tomadas em relação à forma, função e interação do espaço. Além das decisões tradicionais da arquitetura, essas escolhas direcionarão a preferência de sensores, de atuadores e das lógicas a serem implementadas. Elementos do kit gerador, que conformam a lógica interna da arquitetura interativa, serão, então, utilizados para estruturar esse espaço que responde, mais do que à pura aplicação tecnológica, à questões de cunho subjetivo relacionadas ao humano, social e à preservação ambiental.

Em outros espaços, sistemas computacionais são introduzidos para facilitar e dar suporte a atividades cotidianas. Segundo Fox e Kemp (2009) "[...] novas aplicações surgem abordando como a arquitetura interativa pode adaptar para melhorar e ampliar nossas atividades habituais cotidianas assim como ajudar usuários com atividades que eram antes impossíveis ou muito difíceis de serem realizadas" ${ }^{167}$ (p.122). Estas tratam, por exemplo, de espaços que dão suporte à indivíduos específicos, tais como idosos ou portadores de necessidades especiais.

No caso já citado da Performative Ecologies, a intenção de Glynn (2010) era explorar um modelo holístico entre sistema interativo e pessoas, com base na teoria da conversação, e assim a descreve:

(...) No meu caso a conversação é sobre engajamento, e a conversação é uma troca de gestos e de observação. Assim, por um

\footnotetext{
166 Do original em inglês: An interactive building can dynamically mitigate conditions to take advantage of energy conserving strategies such as building orientation and openings to maximize opportunities for daylighting and desired solar heat gain, avoiding unwanted solar heat gain, heat loss, and thermal losses due to wind-driven infiltration, as well as maximizing passive solar and passive cooling opportunities (FOX; KEMP, 2009, p.109).

167 Do original em inglês: Novel applications arise through addressing how interactive architecture can adapt to enhance and extend our normal daily activities as well as assist users with activities that were previously impossible or very difficult to do (FOX; KEMP, 2009, p.122).
} 
lado você tem a máquina que faz esses gestos mas que também está nos observando, e nós estamos fazendo gestos em troca. Nós escolhemos olhar para ela e talvez olha para um de seus vizinhos e nós também os estamos observando. Desse modo, existe um tipo de conversação cíclica ali, entre nossos gestos e observações e seus gestos e observações. Essa máquina está aprendendo sobre nós ao mesmo tempo que estamos aprendendo sobre elas. ${ }^{168}$ (Glynn, 2010)

A perspectiva conversacional da interação é atribuída sobretudo às idéias desenvolvidas por Pask, em especial, durante as décadas de 1960 e 1970. Este era um pensador com formação em engenharia e psicologia, mas que atuava em diversas áreas como cientista, designer, pesquisador, acadêmico e escritor. Suas idéias influenciaram, significativamente, os arquitetos de sua época que buscavam aplicar o pensamento computacional no projeto de arquitetura, tais como Negroponte, Frazer e Price, e continuam a influenciar até hoje. Segundo Haque (2007, p.55):

Agora, no início do século XXI, a Teoria da Conversação de Pask parece particularmente importante pois sugere como, no crescente campo da computação ubíqua, os seres humanos, dispositivos e seus ambientes compartilhados podem coexistir em uma relação mutuamente construtiva. Se pensarmos em ter conversas com nosso ambiente nas quais cada um ter que aprender uns com os outros, então as primeiras experiências de Pask com mecânica e sistemas eletroquímicos fornece uma estrutura conceitual para a construção de artefatos interativos que lidam com a complexidade dinâmica que os ambientes devem ter, sem se tornar prescritivos, restritivos e autocráticos. ${ }^{169}$

Os experimentos aos quais Haque (2007, p.56) se refere, compreendem, dentre outros, o Musicolor Machine (1953), Self-Adaptive Keyboard Instructor (SAKI) (1956) e o Colloquy of Mobiles (1968). "É importante ter em mente que cada um deles é anterior ao computador digital comum e, portanto, foi construído principalmente com componentes analógicos" ${ }^{170}$ (Haque, 2007, p. 56). Estas iniciativas introduzem

\footnotetext{
168 Do original em inglês: [...] In my case the conversation is about engagement and the conversation is an exchange of gestures and observation. So, on one hand you have the machine that is making these gestures but they are also observing us, and we are making gestures in return, we are choosing to look at it and maybe look at one of its neighbors and we're also observing it. So, there's this kind of cyclical conversation in there, between our gestures and our observations and it's gestures and it's observations. This machine is kind of learning about us while we are learning about it (GLYNN, 2010).

169 Do original em inglês: Now, at the beginning of the 21st century, Pask's Conversation Theory seems particularly important because it suggests how, in the growing field of ubiquitous computing, humans, devices and their shared environments might coexist in a mutually constructive relationship. If we think of having conversations with our environments in which we each have to learn from each other, then Pask's early experiments with mechanical and electrochemical systems provide a conceptual framework for building interactive artefacts that deal with the natural dynamic complexity that environments must have without becoming prescriptive, restrictive and autocratic (HAQUE, 2007, p. 55).

170 Do original em inglês: It is worth bearing in mind that each of these predates the common digital computer and was therefore constructed mainly using analogue components(HAQUE, 2007, p. 56).
} 
estruturas para a criação de ambientes interativos que estimule uma relação criativa entre homem e tecnologia. $\mathrm{O}$ autor assim resume os experimentos de Pask:

Neste contexto, suas máquinas de ensino e conversação demonstram sistemas autenticamente interativos que desenvolvem perfis de interação únicos com cada participante humano. Esta abordagem contrasta com a abordagem do "Star Trek Holodek" buscadas muitas vezes nos chamados ambientes inteligentes, que pressupõe que todos nós vemos todas as coisas da mesma maneira, e que nega o papel criativo-produtivo do participante na interação com esses ambientes ${ }^{171}$ (HAQUE, 2007, p.55).

Pask (1970, p.76) define os ambientes que implementam este tipo de interação como aesthetic potent environments (ambientes esteticamente potentes), "[...] ou seja, ambientes destinados a incentivar ou promover um tipo de interação que seja (por hipótese) agradável”172. Por interação agradável, o autor refere-se a um modo genérico de processo mental que as pessoas alcançam ao se envolver em atividades criativas, tais como pintar um quadro, compor uma música, tocar uma música ou mesmo apreciar uma obra de arte. Segundo Pask, para que um ambiente seja capaz de fornecer a base para este tipo de interação este deve conter os seguintes atributos:

(a) Deve oferecer variedade suficiente para proporcionar uma novidade potencialmente controlável exigida por um homem (no entanto, não deve inundá-lo com variedade - se for assim, o ambiente será apenas ininteligível);

(b) Deve conter formas que um homem pode interpretar ou aprender a interpretar em vários níveis de abstração;

(c) Deve fornecer pistas ou instruções implicitamente estabelecidos para orientar o processo de aprendizagem e abstração;

(d) Pode, além disso, responder a um homem, envolve-lo em uma conversa e adaptar as suas características para o modo predominante de discurso. ${ }^{173}$ (PASK, 1970, p.76)

\footnotetext{
171 Do original em inglês: In this context, his teaching and conversational machines demonstrate authentically interactive systems that develop unique interaction profiles with each human participant. This approach contrasts sharply with the 'Star Trek Holodek' approach often attempted in so-called intelligent environments, which presumes that we all see all things in the same way and which denies the creative-productive role of the participant in interactions with such environments (HAQUE, 2007, p.55).

172 Do original em inglês: that is, of environments designed to encourage or foster the type of interaction which is (by hypothesis) pleasurable (PASK, 1970, p. 76).

173 Do original em inglês: (a) It must offer sufficient variety to provide the potentially controllable novelty required by a man (however, it must not swamp him with variety-if it did, the environment would merely be unintelligible). (b) It must contain forms that a man can interpret or learn to interpret at various levels of abstraction. (c) It must provide cues or tacitly stated instructions to guide the learning and abstractive process. (d) It may, in addition, respond to a man, engage him in conversation and adapt its characteristics to the prevailing mode of discourse. (PASK, 1970, p. 76).
} 
De acordo com este pesquisador, para que um ambiente tenha estas características, ele não necessariamente precisa ter tecnologia computacional embarcada em sua estrutura. Entretanto, o autor utiliza as possibilidades tecnológicas para ilustrar com mais profundidade como sua estrutura conceitual pode ser replicada na concepção e construção de espaços mais integrados com o ser humano. Segundo Pask (1969, p.72):

Edifícios sempre foram classificados como obras de arte. A nova sub-teoria é que as estruturas podem ser projetadas (assim como previstas) para promover um diálogo produtivo e prazeroso .... No plano arquitetônico, este tipo de projeto .... atinge a maturidade no trabalho de Gaudí, em especial no Parque Güell .... Enquanto você explorar a coisa, declarações são feitas em termos de liberadores, sua exploração é guiada por feedbacks especialmente planejados, e variedade (valor surpresa) é introduzido em locais adequados para te fazer explorar. ${ }^{174}$

Pask não apenas apresenta uma definição e uma estrutura para este tipo de ambiente como também propõe um modo de design que julga adequado para criação destes espaços, quando entendidos como entidades dinâmicas e não como objetos estáticos. Neste caso, o arquiteto é levado a incluir, em seu escopo de atuação, propriedades não tangíveis tais como o potencial comunicativo do espaço, novos tipos de controle de sua estrutura, ou mesmo regras de evolução, regulagem e ajustes. Neste contexto, de design de ambientes adaptativos e reativos, Pask (1968) descreve as seguintes etapas de criação:

(1) A especificação do objetivo ou meta do sistema (em relação aos habitantes humanos). Deve ser enfatizado que o objetivo pode ser e quase sempre será sub-especificado, ou seja, o arquiteto não vai saber mais sobre o propósito do sistema do que o que ele realmente sabe sobre o propósito de uma casa convencional. Seu objetivo é fornecer um conjunto de restrições que permitem certos modos, presumivelmente desejáveis, de evolução;

(2) A escolha dos materiais básicos ambientais;

(3) Seleção dos invariantes que devem ser programáveis no sistema. Parcialmente nesta fase e na (2) acima, o arquiteto determina quais propriedades serão relevantes no diálogo homem-ambiente;

(4) Especificação de sobre o que o ambiente vai aprender e como ela irá se adaptar;

\footnotetext{
174 Do original em inglês: Buildings have always been classified as works of art. The novel sub-theory is that structures may be designed (as well as intuited) to foster productive and pleasurable dialogue .... At the architectural level, this type of design .... reaches maturity in Gaudi's work, especially the Parque Güell .... As you explore the piece, statements are made in terms of releasers, your exploration is guided by specially contrived feedback, and variety (surprise value) is introduced at appropriate points to make you explore (PASK, 1968, p.72).
} 
(5) A escolha de um plano de adaptação e desenvolvimento. No caso de o objetivo do sistema ser sub-especificado, como em (1), o plano irá consistir principalmente em um número de princípios evolutivos. ${ }^{175}$ (p.75)

De modo geral, esse conjunto de idéias muito contribuem para a perspectiva de espaços interativos que esta pesquisa pretende abordar. Acima de tudo, Pask (1975) oferece uma abordagem não prescritiva para a arquitetura interativa, na qual valores e intenções são partes constituintes de seu discurso. Junto aos modelos holísticos, com base na sustentabilidade e na otimização e facilitação de atividades, essas perspectivas não representam um cenário absoluto de possibilidades, nem mesmo são restritivas, elas apenas indicam leituras plausíveis. Tanto a combinação entre elas, quanto o entendimento, a partir de outros ponto de vista, são possíveis e necessários.

É importante perceber, que a lógica interna dos sistemas digitais são sempre ditadas por entendimentos e modelos de mundo que incluem sua interação com outros sistemas, ou seja, relacionam-se com sua coerência externa. Por mais holísticos que possam ser, esses modelos representam sempre uma redução, uma abstração. Os limites do dentro e do fora nunca são naturais, ao contrário, são resultados de escolhas que se baseiam em julgamentos e pontos de vista. Nesse sentido, cuidados devem sempre ser tomados no que se refere ao entendimento dos valores intrínsecos aos sistemas digitais. Os modelos descrevem a essência dos sistemas, e é apenas por meio de sua explicitação que discussões e questionamentos podem ser conduzidos, de forma a elaborar as questões conceituais trazidas pela arquitetura que os incorporam em sua estrutura.

A incorporação da tecnologia digital nos espaços confere à arquitetura interativa sua especificidade. Materiais, componentes, lógica interna e coerência externa são aspectos interrelacionados que precisam ser compreendidos tanto em conjunto, quanto a partir de suas peculiaridades. Em um nível fundamental, a arquitetura interativa é um dos produtos da relação entre arquitetura e tecnologia digital, e sua criação compreende, entre outros aspectos, a manipulação de seus elementos estruturais e de suas possibilidades comportamentais. A interatividade, no contexto

\footnotetext{
175 Do original em inglês: (1) Specification of the purpose or goal of the system (with respect to the human inhabitants). It should be emphasized that the goal may be and nearly always will be underspecified, ie, the architect will no more know the purpose of the system than he really knows the purpose of a conventional house. His aim is to provide a set of constraints that allow for certain, presumably desirable, modes of evolution. (2) Choice of the basic environmental materials. (3) Selection of the invariants which are to be programmable into the system. Partly at this stage and partly in (2) above, the architect determines what properties will be relevant in the man-environment dialogue. (4) Specification of what the environment will learn about and how it will adapt. (5) Choice of a plan for adaptation and development. In case the goal of the system is underspecified, as in (1), the plan will chiefly consist is a number of evolutionary principles (PASK, 1968, p.75).
} 
aqui colocado, amplia as possíveis formas de manifestação da arquitetura como um todo.

A aplicação a de recursos interativos relaciona-se com encontrar o momento correto de usá-los da forma correta. E não utilizá-los porque é possível, ou por estar disponível, ou porque outras pessoas estão usando. Mas utilizá-los porque há um propósito para tal, há um significado, há uma narrativa. Provavelmente há um significado para você fazer isso, aí sim faz sentido. ${ }^{176}$ (SAUTER, 2010)

Interações mais complexas não criam automaticamente espaços mais interessantes, úteis, funcionais, sustentáveis ou belos. Apesar de não haver razões que tornem o interativo melhor, existe algo único em estruturas capazes de se engajar em trocas dinâmicas com seu contexto e capazes de modificar esse comportamento com o passar do tempo. Essas possibilidades colocam oportunidades específicas de expressão que diferenciam os espaços interativos daqueles "não-interativos".

A interação implementada por meio da computação possui qualidades próprias, assim como qualquer outro elemento passível de ser adicionado aos espaços. Mais do que definir o que é melhor ou pior, mais ou menos, novo ou velho, o importante é reconhecer que cada recurso promove possibilidades distintas e possui suas próprias qualidades.

Nesse sentido, a dinâmica e a interatividade não são essenciais, mas são recursos que precisam ser entendidos e incorporados na paleta de possibilidades arquitetônicas de maneira fundamentada e consciente. Nesse sentido, espera-se que a fundamentação da arquitetura interativa, aqui colocada, ofereça elementos suficientes para expandir o entendimento conceitual que envolve a incorporação de sistemas digitais no espaço construído.

\footnotetext{
176 Do original em inglês: Its about finding the right moment where to use it in the right way. And not to use it because you can use it, or not only because it's available, or not only because the others are doing it but doing it because there's a purpose to do it, there's a meaning, there's a narration probably there's a meaning why you do it, and then it makes sense (SAUTER, 2010).
} 
O elemento motivador desta pesquisa é o design da arquitetura interativa, tema deste capítulo. A necessidade de elucidar questões teóricas e práticas necessárias para a criação fundamentada deste tipo de espaço, guiou a elaboração dos capítulos anteriores. De tal modo, o entendimento da complexidade dos contextos, somado à definição das particularidades deste tipo de espaço, compõem a base para discutir seu processo de design.

A discussão, aqui colocada, é resultado da adoção de premissas específicas que guiaram o processo de investigação deste trabalho. A principal, parte da hipótese que o design de interações, campo do conhecimento cujo escopo engloba a criação de produtos interativos, possui elementos práticos e conceituais de extrema relevância para o design da arquitetura interativa. Nesse sentido, é importante ressaltar que o conteúdo apresentado resulta, especificamente, da aproximação entre essa área, em particular, com a arquitetura. O movimento empreendido buscou, desde o início, revelar as oportunidades e limitações desse intercâmbio, de tal forma que estratégias para o design de arquiteturas interativas pudessem ser sistematizadas.

Para elucidar os resultados alcançados, faz-se necessário, primeiramente, contextualizar especificidades do processo de design no campo da arquitetura e do design de interações. Isso é feito com o intuito de esclarecer questões específicas recorrentes em cada uma dessas áreas do conhecimento, de indicar pontos de contato, bem como esboçar métodos e conceitos que, adaptados, podem ser úteis para a criação de espaços interativos.

Em um segundo momento, são descritos processos de design que ilustram, na prática, o diálogo entre esses campos. O Ambiente Interativo D3 é um projeto de espaço empresarial (uma sala de $70 \mathrm{~m}^{2}$ ) que utiliza sistemas computacionais customizados 
para expressar aspectos conceituais da arquitetura como um todo. Para alcançar tal, resultado foram incluídas estratégias específicas em seu processo de design, inspiradas pelo design de interações. Os projetos Low2No e FredericiaC+ são propostas de desenvolvimento urbano que incluíram, em sua equipe, escritórios de engenharia, arquitetura e design de interações. Portanto, indicam possibilidades interessantes de diálogo entre as áreas. A participação no desenvolvimento desses projetos foi parte importante do processo de investigação dessa pesquisa e influenciaram fortemente os resultados alcançados, tanto por possibilitar a investigação prática de questões teóricas, como por indicar a inclusão de temas complementares.

Por fim, são esboçados alguns parâmetros sistematizados por esta pesquisa para guiar o design da arquitetura interativa. Os parâmetros compreendem princípios elaborados para fornecer aos arquitetos e designers elementos conceituais passíveis de serem manipulados. Estes parâmetros possuem uma tripla função: podem ser utilizados para auxiliar o entendimento das especificidades deste tipo de arquitetura, adotados como um conjunto de requisitos a serem ponderados, e, também, incorporados como um vocabulário comum entre grupos que se ocupam com sua criação.

\subsection{Processos de design}

Falar em processos pressupõe duas questões, tempo e diferença. Processos estão ligados ao movimento de algo e, para que o movimento seja compreendido enquanto tal, faz-se necessária a percepção de diferença(s) entre um suposto estado inicial e um estado final, entre um antes e depois. Se nenhuma diferença for percebida, pode-se afirmar que nada aconteceu, ou seja, nenhuma descrição de processo pode ser derivada dessa observação, pois não houve transformação. Fundamentalmente, processos são subjetivos, porque dependem do olhar do observador e da definição $a$ priori tanto do estado inicial e dos parâmetros de comparação, quanto do tempo utilizado para marcar as mudanças. Essa relação com pontos de vista é destacada por Dubberly (2004, p.13), ao descrever a qualidade fractal dos processos:

Processos possuem uma qualidade fractal. Você pode ampliar ou reduzir, aumentando ou diminuindo a abstração ou especificidade. Você pode adicionar mais detalhes - dividindo fases em etapas e etapas em sub-etapas, quase infinitamente. Processos raramente possuem começos e finais fixados. Você pode quase sempre adicionar etapas acima ou abaixo.177

177 Do original em inglês: Processes have a fractal quality. You can zoom in or out, increasing or decreasing abstraction or specificity. You can add more detail-dividing phases into steps and steps into sub-steps, almost 
Como Jones (1992, p.4) ${ }^{178}$ aponta, o termo processos de design pode designar diversas conotações, de forma que "[...] parece haver tantos tipos de processos de design quanto há escritores sobre o assunto" ${ }^{179}$. Contudo, quando a palavra design é entendida como atividade de projeto, todas as descrições incluem, de certa maneira, a produção de diferenças, durante, como resultado de cada ação, e no final do processo. Essas descrições podem ser tanto adequadas às expectativas iniciais quanto inferiores ou superiores a tais. Da mesma forma, a medição da diferença alcançada pode, ainda, depender do ponto de vista de quem analisa o processo.

Isso posto, pode-se questionar a existência de inúmeros outros processos capazes de produzir diferença. Em resposta a tal argumento, Jones (1992, p.10) descreve a singularidade dos processos de design como uma mistura de três outros modelos de pensamento, também, voltados para a produção de diferenças, quais sejam: o científico, o matemático e o artístico. Nessa perspectiva, o design enquanto ação, "[...] é uma atividade híbrida que depende, para a sua realização bem-sucedida, de uma combinação adequada de todos os três, e é mais difícil ser bem sucedido se for exclusivamente identificado com qualquer um"180.

Além de se identificar com esses outros campos, o design é singular, pois, em sua essência, trata como real o que existe em um futuro imaginado e tem como objetivo a especificação de ações que possam tornar essa visão realidade. A ciência e a arte, cada um da sua maneira, partem do momento histórico presente como principal insumo para suas ações, enquanto a matemática é atemporal por tratar de relações abstratas independentes de contextos (JONES, 1992, p.10).

Uma vez que, para poder imaginar futuros, o designer precisa conhecer o presente, os métodos científicos - cujo objetivo é descrever e explicar sistematicamente fenômenos observados - possuem seu lugar nos processos de design (JONES, 1992). A intuição artística - capacidade de diálogo intenso com imagens mentais de possíveis soluções durante o processo - é importante para designers por se tratar da exploração rápida e instintiva de possibilidades. Na matemática, uma vez que um problema é

infinitely. Processes rarely have fixed beginnings or endings. You can almost always add steps upstream or downstream (DUBBERLY, 2004, p.13).

178 A edição utilizada para consulta foi a de 1992, mas é importante apontar que a primeira edição do Design Methods de Jones foi publicada em 1973.

179 Do original em inglês: [...] there seem to be as many kinds of design process as there are writers about it (JONES, 1992, p.4).

180 Do original em inglês: [...] it is a hybrid activity which depends, for its successful execution, upon a proper blending of all three and is most unlikely to succeed if it is exclusively identified with any one (JONES, 1992, p. 10). 
representado, simbolicamente, ele passa a ser real, não há necessidade de explicar intenções e motivações que guiaram sua elaboração, o que importa é sua solução lógica. Essa estratégia é útil, quando se chega a um problema estável e bem definido pois pode otimizar a procura de soluções para tal. Acima de tudo, quando um problema de design pode ser descrito matematicamente, significa que ele pode ser implementado por um computador, fato este de grande relevância frente a crescente simbiose entre design e tecnologia digital.

As descrições elaboradas pelo autor fazem parte de um contexto maior de questionamento, característico da segunda metade do século XX (pós II guerra). Até então, design era simplesmente a atividade empreendida, dentre outros, por arquitetos, engenheiros e desenhistas industriais, para produzir desenhos e propostas. $\mathrm{O}$ questionamento dos modos tradicionais (modernistas) de trabalho e a necessidade de criar novos procedimentos para necessidades emergentes, culminaram na "[...] tentativa de isolar a essência do design e descrevê-lo como um método padrão ou uma receita, que pode servir de base para todas as situações" ${ }^{181}$ (JONES, 1992, p.3).

Como aponta Bazjanac (1974, p.6), os primeiros modelos desenvolvidos com o intuito de esclarecer a natureza dos processos de design possuíam uma característica em comum, "[...] todos eles veem o processo de design como uma sequência de atividades bem definidas e são todos baseados no pressuposto de que as ideias e os princípios do método científico pode ser aplicado a ele" ${ }^{182}$. Partia-se do pressuposto de que, uma vez definido o problema, a aplicação de procedimentos sistemáticos, logicamente, permitiriam que melhores soluções fossem prontamente determinadas. As críticas a essas primeiras iniciativas argumentavam que o “[...] design não é um processo estritamente seqüencial, e problemas de projeto são 'wicked'183, e um processo linear passo-a-passo aplicado a eles não pode, por si só, resultar em quaisquer soluções"184 (BAZJANAC, 1974, p.8).

\footnotetext{
181 Do original em inglês: [...] the attempt to isolate the essence of designing and to write it down as a standard method, or recipe, that can be relied upon in all situations (JONES, 1992, p.3).

182 Do original em inglês: [...] they all view the design process as a sequence of well defined activities and are all based on the assumption that the ideas and principles of the scientific method can be applied to it (BAZJANAC, 1974, p.6).

183 Wicked problems (sem tradução direta para o português), são essencialmente problemas mal-definidos. Bazjanac cita a definição dada por Horst Rittel ao termo, na qual, wicked problems é uma classe de problemas do sistema social que são mal-formulados, na qual a informação é confusa, na qual existem vários clientes e formadores de opinião com valores conflitantes, e na qual as ramificações no sistema como um todo são completamente confusas (Rittel apud BAZJANAC, 1974, p.8-9). Do original em inglês: ... class of social system problems which are ill formulated, where the information is confusing, where there are many clients and decision makers with conflicting values, and where the ramifications in the whole system are thoroughly confusing 184 Do original em inglês: [...] design is not a strictly sequential process, and design problems are 'wicked' and a linear step-by-step procedure applied to them cannot by itself yield any solutions (BAZJANAC, 1974, p.8).
} 
Inúmeras críticas apareceram, porém a intenção das propostas de revisão desses entendimentos mais aprimorar a compreensão dos processos, do que refutar a validade de qualquer tentativa de sistematização. Assim sendo, os inúmeros métodos descritos naquela época, em especial aqueles elencados no glossário de métodos, organizado por Jones em 1973, ainda são de grande relevância para variados processos contemporâneos (JONES, 1992). O desdobramento dessas críticas levou a um entendimento do processo de design enquanto um processo argumentativo, ou seja, "[...] um processo que envolve mudar o modo como se percebe a situação 'conversando'"' (LAWSON, 2011, p. 246). Nesse processo, a tentativa de solucionar um problema pode levar à redefinição do próprio problema.

Segundo Lawson (2011, p.245), é mais fácil perceber o processo de design como uma conversa, quando o trabalho é realizado em equipes, onde "[...] o processo é realizado, pelo menos em parte, com as conversas que acontecem entre os integrantes dessas equipes". Porém, essa conversa pode acontecer, também, entre o designer e as diferentes formas de representação (dos desenhos aos modelos computacionais), assim como na imaginação do designer, desde que as estratégias adotadas atuem para sustentar linhas de pensamento específicas, sobre o problema em questão. Nesse modelo circular, no qual representações geram novas informações que são retroalimentadas, no processo como um todo, etapas continuam existindo, mas não são descritas, a partir da seqüência de atividades ou aplicação de métodos específicos. O que era visto antes como etapas do processo é, atualmente entendido mais como uma forma de trabalho que perpassa o processo como um todo.

Essas perspectivas generalizantes dos processos de design, assim como o entendimento do design enquanto um objeto a ser estudado do qual teorias podem ser derivadas é um ponto de encontro importante para as diferentes práticas que, daí, se desdobram. A partir de então, o interesse maior desta pesquisa é esclarecer o que há de específico entre diferentes áreas, em especial, na arquitetura e no design de interação. Acredita-se que são essas diferenças que se desdobram, a partir dos entendimentos genéricos, que podem indicar as oportunidades de diálogo que este trabalho procura.

\subsubsection{Arquitetura}

Curiosamente, as principais iniciativas que buscaram sistematizar processos de design, na década de 1960 e 1970, partiram de arquitetos, tais como Alexander (1964) e Broadbent (1974). Isso pode até parecer estranho, pois nem sempre essas discussões 
são trazidas às escolas de arquitetura, em especial, àquelas com forte tradição modernista. Contudo, foi a insatisfação com a produção modernista que inspirou outros arquitetos a investigarem questões relacionadas aos processos de design e de solução de problemas, em geral.

A história contada no livreto de visitação da Villa Savoye - casa projetada por Le Corbusier e ícone da arquitetura moderna - ilustra bem um dos pontos recorrentemente criticado. Nela fica nítida a distância entre a intenção inicial de se criar uma máquina para morar e uma máquina para produzir emoções (palavras do arquiteto citadas na contracapa da edição), e o que realmente aconteceu.

O projeto alcançou a aprovação dos clientes, mas colocá-lo em prática logo mostrou ser outra questão. A construção mal havia sido concluída, no verão de 1931, quando se descobriu que a casa - como muitos edifícios modernos da época - não era resistente à água, sendo a rampa a principal culpada. Uma primeira campanha de restauração, portanto, teve que ser organizada, os principais objetivos eram impermeabilizar os terraços e restaurar o trabalho de pintura, mas o arquiteto teve pouco interesse no processo! A casa não era muito confortável e os seus proprietários logo a abandonaram"185 (MOREL-JOURNEL, 2000, p.7).

Essa distância, entre intenção e resultado das quais os edifícios modernos são acusados, normalmente causa controvérsia. Por um lado, esses edifícios, ainda, são mostrados como exemplos de boa arquitetura e seus princípios são recorrentemente reproduzidos. Por outro, essa disparidade é o ponto de partida para discussões sobre o papel do arquiteto e da arquitetura, na sociedade como um todo.

Lang et al (1974, p.5) segue essa segunda inclinação, ao comentar três perspectivas que, para ele, elucidam aspectos da natureza problemática da arquitetura moderna. A primeira é decorrente da relação paternalista do arquiteto, em relação aos clientes e futuros usuários dos espaços que projetam. Esse tipo de aproximação parte, normalmente, de uma premissa generalista na qual “[...] todas as pessoas vão perceber as possibilidades no ambiente projetado da mesma forma que ele [o arquiteto] as veem" ${ }^{186}$.

\footnotetext{
185 Do original em inglês: The project met with the client's approval, but putting it into practice soon proved to be quite another matter. Hardly had building been completed, in the summer of 1931, when it was discovered that the house - like many modern buildings of that time - was not watertight, the main culprit being the ramp. A first restoration campaign therefore had to be organized, the main objectives begin to seal the terraces and restore the paint work, but the architect seems to have taken little interest in the proceedings! The house was not very comfortable and its owners soon abandoned it (MOREL-JOURNEL, 2000, p.7).

186 Do original em inglês: [...] all people will perceive opportunities in the designed environment in the same way that he [the architect] sees them (LANG et al, 1974, p. 5).
} 
Broadbent (1973, p. 76-77) complementa essa visão ao afirmar que observação e análise de usuários faziam, sim, parte do processo desses arquitetos, entretanto, isso acontecia com o intuito de delinear padrões básicos aplicáveis a todas as pessoas. Partia-se do princípio de que os seres humanos são, essencialmente, iguais, já que possuem o mesmo organismo, mesmas funções e necessidades. Uma vez que o arquiteto - conhecedor e mestre - estabelecia o modelo do homem moderno ideal, cabia às pessoas adaptaram-se aos espaços e edifícios que construíam. Assim sendo,

Eles criaram sistemas auto-consistentes de tempos em tempos, com base em percepções pessoais; eles até tentaram formular verdades auto-evidentes ou axiomas. Pensa-se em "a forma segue a função" de Sullivan, no "espaço interno é a realidade do edifício" de Wright, ou "o plano é o gerador" de Le Corbusier. Na melhor das hipóteses, esses arquitetos conseguiram uma fusão maravilhosa entre racionalismo e empirismo (o que é particularmente verdade com Wright), mas [...] quanto mais se aproximavam do racionalismo puro, menos satisfatórios seus edifícios provaram ser, do ponto do conforto do usuário. [...] Já era ruim o suficiente quando seu racionalismo determinava a forma do edifício em si, mas, na pior das hipóteses, ele também se estendida para tentar determinar as vidas que as pessoas deveriam viver dentro dele. ${ }^{187}$ (BROADBENT, 1973, p.75)

A segunda questão problemática dos arquitetos modernos é a que Lang et al (1974, p.5) denomina de determinismo arquitetônico, “[...] a crença que o ambiente projetado tem grande um impacto no comportamento social" ${ }^{\prime 188}$. Se essa premissa fosse verdadeira, a substituição de favelas e assentamentos por moradias dignas seria suficiente para eliminar grande parte dos problemas sociais de uma cidade. Mesmo se essa hipótese tivesse algum fundamento, caso o significado de digno fosse imposto sem entender os valores locais, e se essas novas moradias fossem construídas para apenas um tipo idealizado de homem, ainda assim, seria difícil visualizar esse cenário com entusiasmo. O desenrolar da apropriação de alguns edifícios modernos mostra outra realidade. Como os autores apontam,

\footnotetext{
187 Do original em inglês: They set up self-consistent systems on the basis of personal insights from time to time; they even tried to formulate self-evident truths or axioms. One thinks of Sullivan's 'form follows function', Wright's 'internal space is the reality of the building', or Le Corbusier 'the plan is the generator'. At their best, these architects achieved a marvelous fusion between rationalism and empiricism (which is particularly true of Wright). but,[...] the closer they approached to pure rationalism, the less satisfactory their buildings prove to have been, from the point of user comfort.[...] It was bad enough when their rationalism determined the form of the building itself, but at worst it extended also to trying to determine the lives which people should live within it (BROADBENT, 1973, p.75).

188 Do original em inglês: [...] the belief that the designed environment has a major impact on social behavior (LANG et al, 1974, p.5).
} 
Agora é claro que a probabilidade de qualquer comportamento espacial, cognitivo ou emocional - é uma função complexa de hábitos e intenções de uma pessoa, bem como fatores que podem ser considerados como facilitadores desse comportamento. As próprias intenções são uma função de pressões sociais, do desejo de determinado comportamento para a pessoa ou pessoas envolvidas, e das suas consequências percebidas. Os facilitadores podem ser de natureza arquitetônica, mas também é provável que seja administrativa, financeira ou algum outro fator ${ }^{189}$ (LANG et al, 1974, p.5-6).

De um modo geral "[...] os arquitetos devem parar de impor projetos que eles, como uma sub-cultura, gostam, a pessoas com diferentes conjuntos de necessidades e

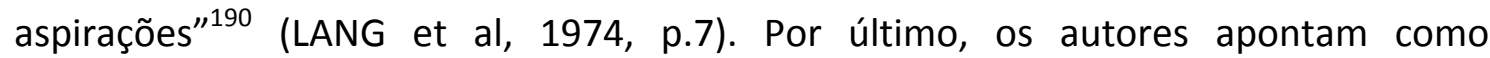
problemático o fato de que, na maioria das vezes, os teóricos da arquitetura preocupam-se, especialmente, com a relação entre o arquiteto e o artefato que ele produz. Ou seja, a principal questão das teorias da arquitetura, muitas vezes, é como o arquiteto se relaciona e interpreta seu contexto, faz uso das ferramentas e dos materiais disponíveis, e quais formas, tipos e estilos arquitetônicos são derivadas desse processo. "Não tem se centrado na compreensão de como o ambiente é percebido, o significado que ele tem para as pessoas tanto em termos concretos quanto simbólicos, ou as oportunidades que as diferentes pessoas percebem nele"191 (LANG et al, 1974, p.8).

As críticas de LANG et al (1974) podem até incluir argumentos contestáveis, mas ilustram algumas das principais questões levantadas nas décadas de 1960 e 1970, em especial sobre a limitação da abordagem modernista da criação da arquitetura. Nessa conjuntura, as sistematizações de processos de design foram realizadas em contraposição à tradicional aproximação assistemática da observação e análise, que se mostraram incapazes de lidar com os problemas mais complexos, com a heterogeneidade de clientes e usuários dos espaços bem como com as mudanças nas necessidades dessa época. Além disso, como foi abordado no primeiro capítulo, a ciência viveu seu auge, após a segunda guerra mundial, e não tardou para que

\footnotetext{
189 Do original em inglês: It is now clear that the probability of any behavior - spatial, cognitive, or emotional - is a complex function of a person's habits and intentions as well as factors which can be regarded as facilitators of that behavior. The intentions themselves are a function of social pressures, the desirability of that particular behavior for the person or people involved, and its perceived consequences. The facilitators may be architectural in nature, but they are just likely to be administrative, financial or some other factor (LANG et al, 1974, p.5-6). 190 Do original em inglês: [...] architects must get away from imposing designs which they as subculture like on people with different sets of needs and aspirations (LANG et al, 1974, p.7).

191 Do original em inglês: It has not focused on understanding how the environment is perceived, the meaning it has for different people in either concrete or symbolic terms, or the opportunities that different people perceive in it. (LANG et al, 1974, p.8).
} 
aproximações sistemáticas fossem transpostas para a arquitetura, como aponta Bazjanac (1974, p.5):

Quando pesquisadores de operação e cientistas da computação comerçar a alegar sucesso nas aplicações de seus métodos na indústria e em outras disciplinas, foi apenas uma questão de tempo até esses métodos chegarem na arquitetura e causarem uma mudança no pensamento sobre o processo de design e os produtos do design"192

A partir desse momento, surge, então, o principal esforço empreendido por Broadbent (1974) ao analisar possibilidades de diálogo entre a arquitetura e os diversos temas emergentes da ciência naquele tempo. O autor destaca, por exemplo, a relevância das questões procedentes da pesquisa operacional e técnicas de resolução de problemas em geral; dos modelos sociológicos de como as sociedades se organizam e funcionam desenvolvidas pelas ciências humanas; da nova matemática, que inclui, dentre outros, estudos topológicos, teoria dos grafos e topologia, geometria e morfogênese celular; do design assistido por computador bem como diversas outras questões.

Com essa aproximação, Broadbent (1974, p. xiv) procura introduzir as principais idéias e terminologias de cada campo para auxiliar arquitetos e designers a procurarem as informações de que precisam, colaborarem com diferentes campos do conhecimento e, assim, expandir sua prática. Como relata, "[...] em cada caso, tentei olhar para os assuntos como arquiteto, preocupado com decisões de design, procurando abstrair deles aqueles aspectos que pareciam mais relevantes para o design" ${ }^{193}$.

A integração de métodos e conhecimentos analíticos ao processo de design é, e deve sempre ser, encarada com cautela e desconfiança. No entanto, o receio de que a racionalização extrema pudesse vir a substituir a criatividade não tem impedido que arquitetos explorem e extrapolem os programas computacionais, implementando modelos e algoritmos advindos de outras áreas do conhecimento para explorar possíveis espacialidades e técnicas construtivas para seus projetos, como abordado no item 2.1.1 desta tese. A cada dia mais, a complementaridade dessas questões, aparentemente contraditórias, têm sido assumidas e cultivadas por arquitetos e designers em geral. Tal fato pode ser observado no que Kolaveric (2003) denomina de

\footnotetext{
192 Do original em inglês: When operations researchers and computer scientits started claiming success in the applications of their methods to industry and some other disciplines, it was only a question of time before those methods reached architecture and caused a change in thinking about the design process and the products of design (BAZJANAC, 1974, p.5).

193 Do original em inglês: In each case, I have tried to look at the subject as an architect, concerned with design decisions, trying to abstract from it those aspects which seem most relevant to design (BROADBENT, 1974, $\mathrm{p}$. xiv).
} 
"arquitetura da era digital", caracterizada, sobretudo, por estratégias que utilizam integralmente a tecnologia nos processos de design, produção e construção de edifícios.

Segundo Kolaveric (2003, p.13), a principal característica dessa arquitetura reside, não nas formas contínuas e curvilíneas, mas sim, nos processos que as originam. Ao descrevê-los enfatiza, em um primeiro momento, a utilização da tecnologia como uma ferramenta para a geração e transformação da forma. Segundo o autor,

"[...] em vez de modelar uma forma externa, os designers articulam uma lógica interna geradora que, em seguida produz, de forma automática, uma gama de possibilidades, a partir das quais o designer pode escolher proposições formais adequadas para um maior desenvolvimento"194.

Nessa perspectiva, relações formais previsíveis são substituídas por complexidades geradas pelo computador. Somadas à utilização de algoritmos para gerar a forma, Kolaveric (2003) destaca também a influência exercida pelos processos digitais de produção (computer aided manufacturing - CAM) no processo de criação da arquitetura da era digital. Não apenas as formas complexas são exploradas, como também, o fato dessas formas serem descritas precisamente e passíveis de serem computadas, as tornam aptas a serem construídas por meio de processos baseados em controles numéricos computadorizados (computer numeric control - CNC). Isto posto, o autor aponta que,

“[...] a conseqüência é que arquitetos estão se tornando muito mais diretamente envolvidos nos processos de fabricação, já que criam a informação que é traduzida por fabricantes diretamente nos dados de controle que comandam o equipamento digital de fabricação"195 (KOLAVERIC, 2003, p.33).

O projeto SeedArchSystem ${ }^{196}$, desenvolvido durante workshop oferecido pela Architectural Association (AA), no Rio de Janeiro, ilustra bem algumas características desses novos processos (Figura 87-99). O workshop foi realizado no barracão da Escola de Samba Infantil Pimpolhos, e sua proposta incluía a experimentação com máquinas de fabricação digital (CNC, impressora a laser, corte de adesivos) no contexto de

\footnotetext{
194 Do original em inglês: [...] instead of modeling an external form, designers articulate an internal generative logic, which then produces, in an automatic fashion, a range of possibilities from which the designer could choose an appropriate formal propositional for further development (KOLAVERIC, 2003, p. 13).

195 Do original em inglês: [..] the consequence is that architects are becoming much more directly involved in the fabrication processes, as they create the information that is translated by fabricators directly into the control data that drives the digital fabrication equipment (KOLAVERIC, 2003, p. 33).

196 Projeto desenvolvido por Gabriela Carneiro, Helena Daher, Isabela Ferrante e Mariana Bomtempo (2011).
} 
produção tradicional do carnaval. Além da introdução a softwares tais como Rhino e seu plugin Grasshopper, assim como Arduino, Processing e Ecotec, foram feitas várias visitas a barracões de outras escolas de samba nas quais os participantes tiveram contato com resultados da produção artesanal que deram origem às fantasias e aos carros alegóricos.

A partir desse contexto, foi conduzido um processo exploratório, cujo objetivo era a criação de um sistema arquitetônico que pudesse ser utilizado para gerar diferentes espaços. O nome seed, que em português significa semente, refere-se à unidade básica desse sistema, composto por células, junções e comportamentos que podem ser

Figura 87-89: Estudo de implantação de instalção, criada com o seedArchSystem (Fonte: Gabriela Carneiro)
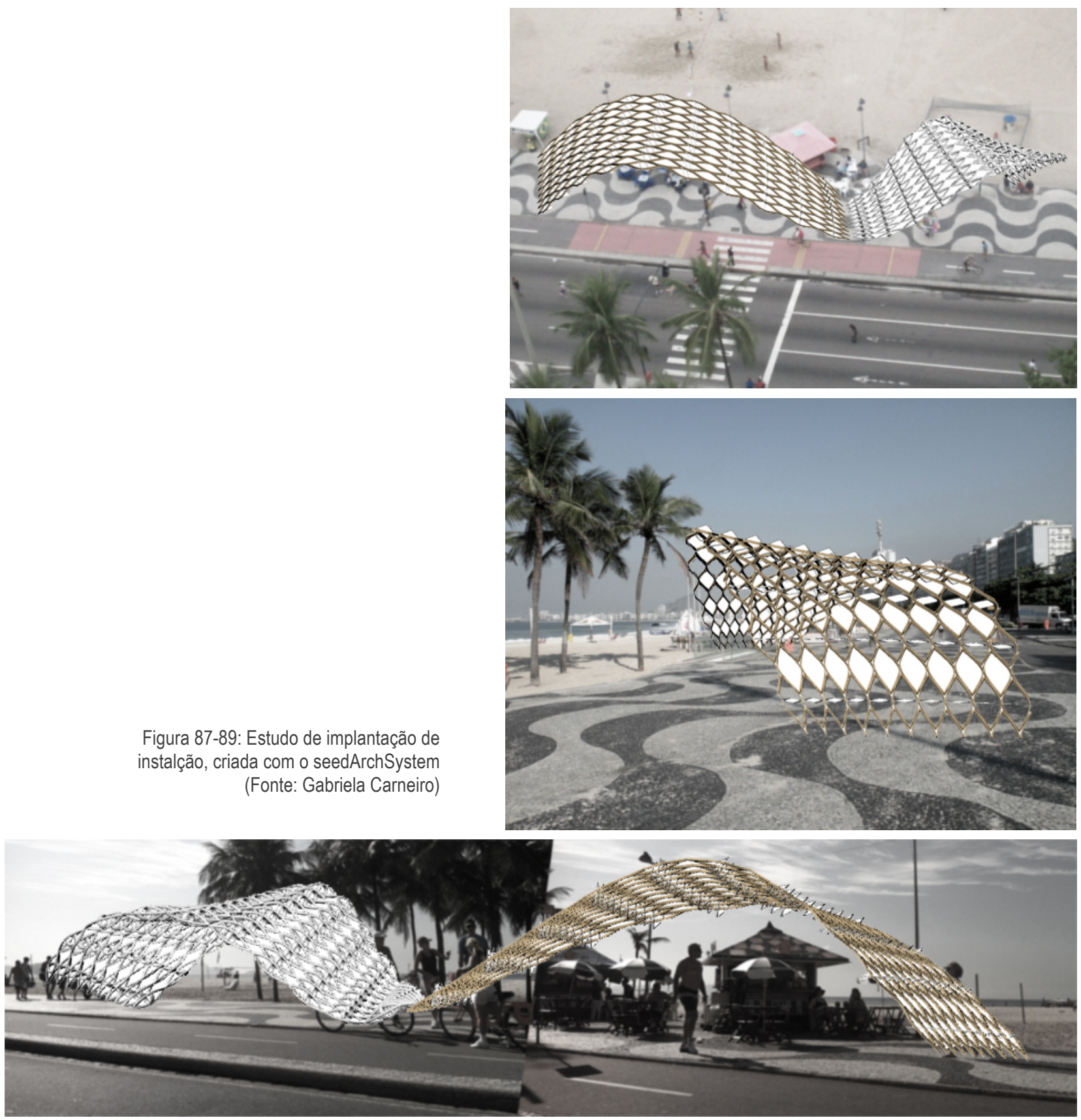

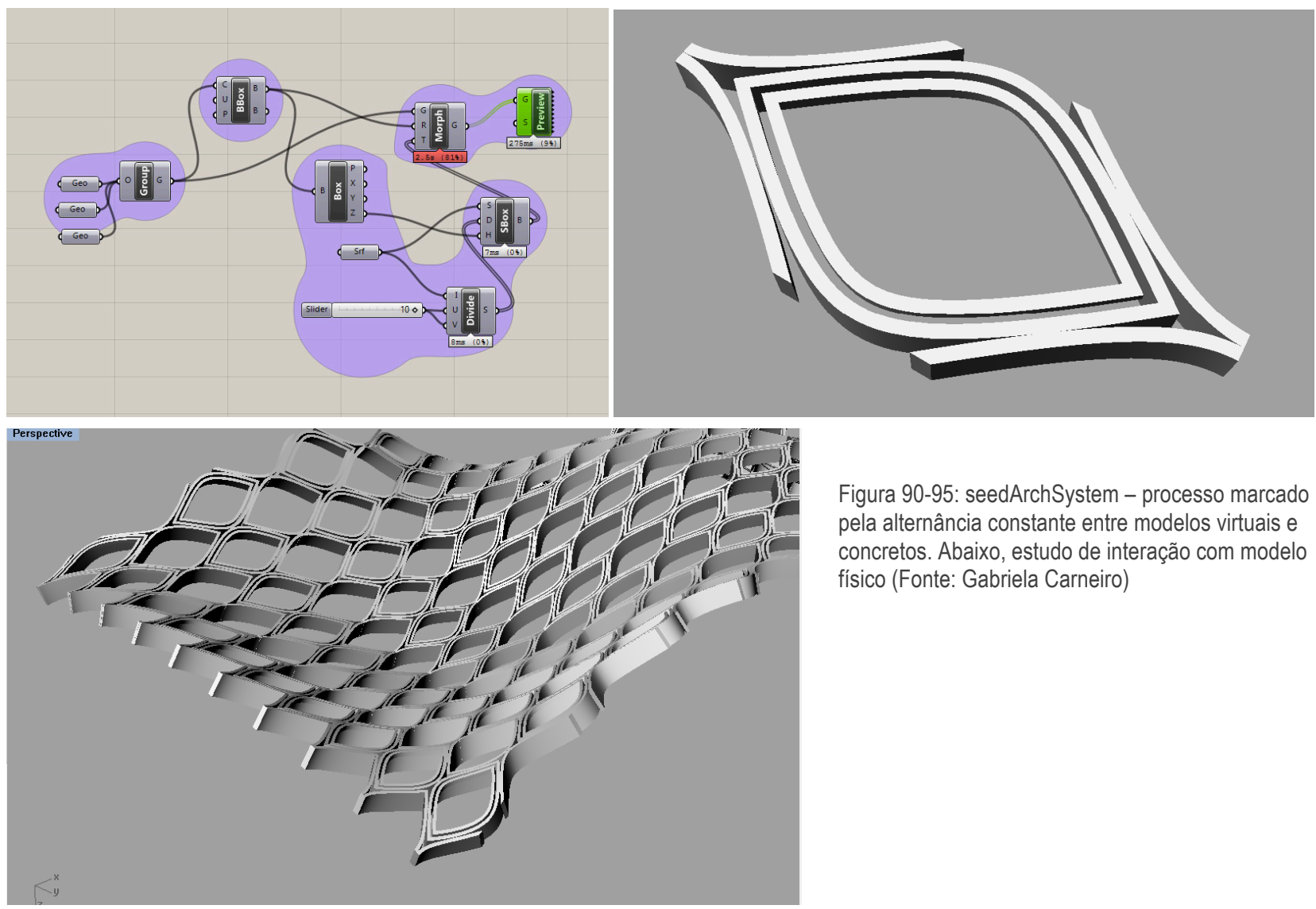

Figura 90-95: seedArchSystem - processo marcado pela alternância constante entre modelos virtuais e concretos. Abaixo, estudo de interação com modelo físico (Fonte: Gabriela Carneiro)
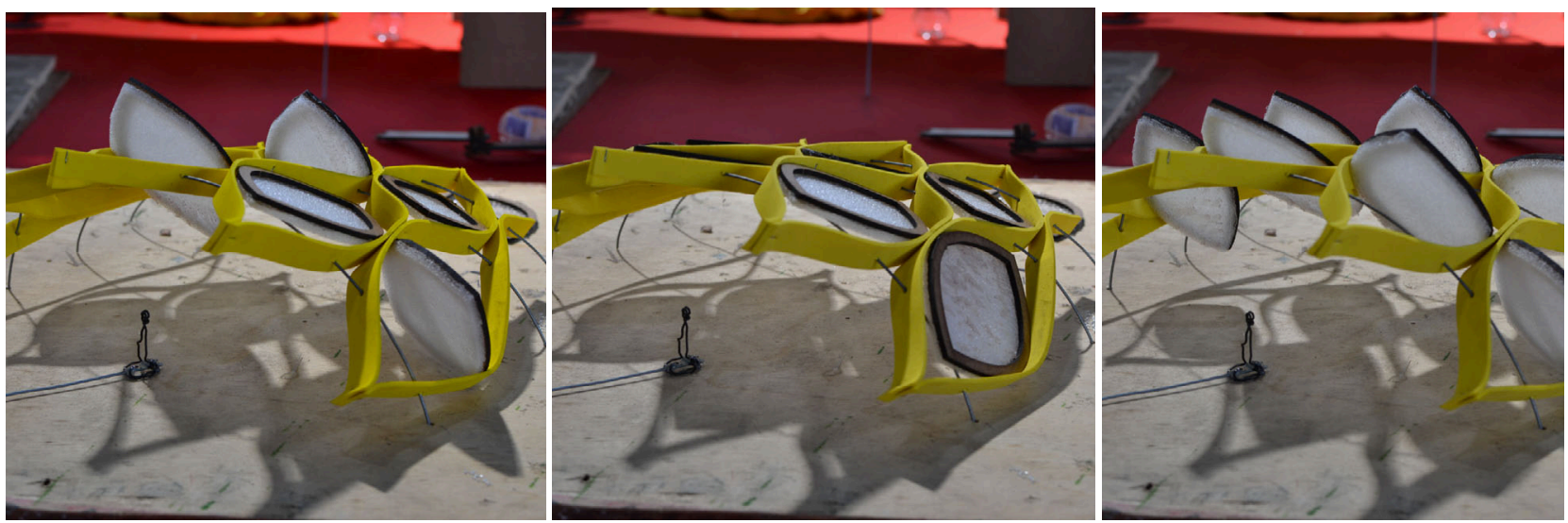

replicados e aplicados para criar superfícies interativas e adaptáveis. O processo foi caracterizado por duas abordagens simultâneas e complementares: uma partia da investigação de materiais, estruturas e junções e outra empenhava-se na exploração de superfícies, contextos e espacialidades.

Modelos físico e digital foram empregados em um processo contínuo de retroalimentação, em que os avanços e as novas informações trazidas pela exploração de um eram sistematicamente introduzidas no desenvolvimento do outro (Figura 9095). Um aspecto importante a ser destacado é a utilização dos modelos como parte 

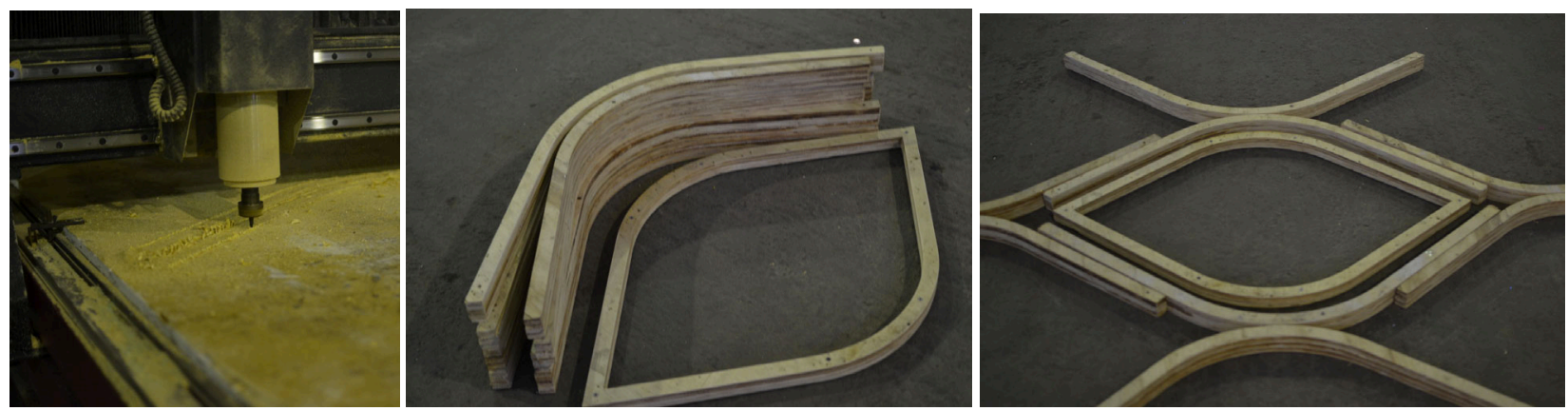

Figura 96-98 - acima: seedArchSystem - produção do protótipo 1:1 com CNC e montagem (Fonte: Gabriela Carneiro)

Figura 99-100 - abaixo: seedAcrhSystem- protótipo 1:1 da célula (esq.) e maquete final de PVC, cortada à laser (dir.) (Fonte: Gabriela Carneiro)
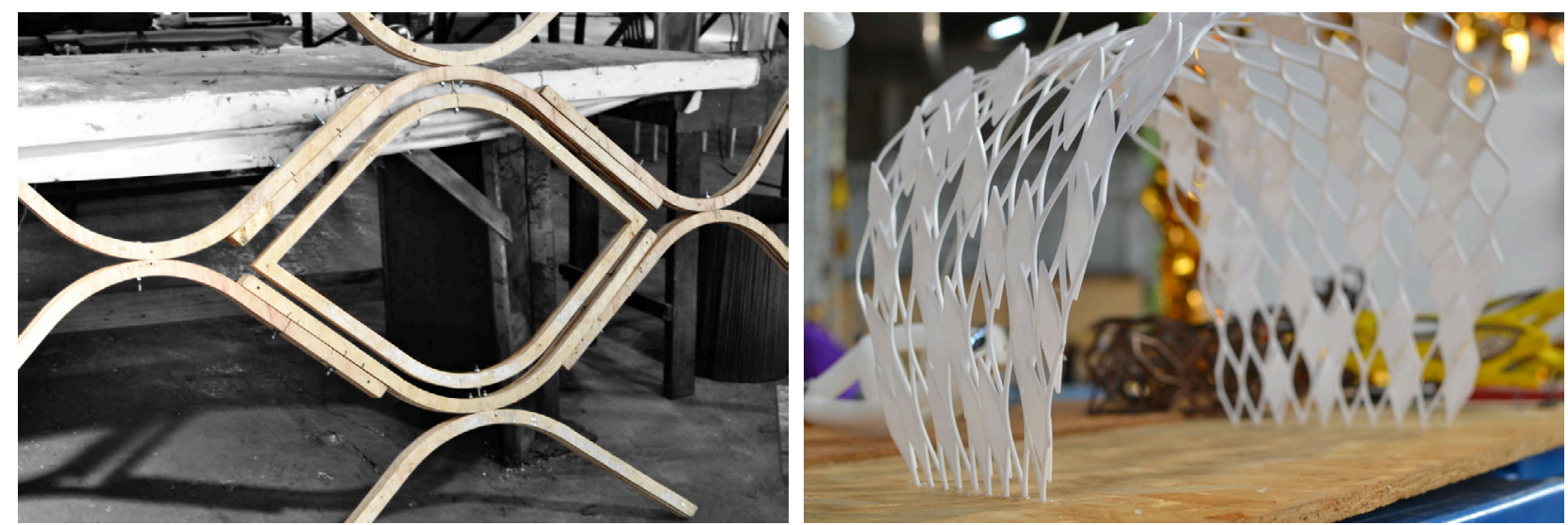

importante no processo argumentativo do desenvolvimento da proposta, e não apenas para comunicar e ilustrar idéias. A execução de cada novo modelo era sempre feita de forma a produzir mais informações para o processo como um todo. Ao final, as informações produzidas para produção dos modelos de estudo foram praticamente as mesmas que alimentaram as máquinas para cortar a madeira do protótipo 1:1 (Figura 96-100).

Os avanços científicos e tecnológicos têm influenciado não apenas os processos de design, mas também, a maneira de o arquiteto compreender o mundo como um todo. Nesse sentido, Fox e Kemp (2009) apontam uma mudança de paradigma, do mecânico para o biológico, que acompanha esse desenvolvimento, na qual as questões pragmáticas e funcionais são apenas parte da história. A adoção de analogias com processos naturais, a partir de princípios biologicamente inspirados, também se desenrola na reinterpretação de como o arquiteto trabalha e vê o mundo. A partir dessa perspectiva, o arquiteto passa a atuar como o catalisador de processos que evoluem, e a arquitetura como um sistema vivo em constante transformação.

É notável que, com essas novas ferramentas, outros entendimentos de mundo estão sendo introduzidos na arquitetura - que a cada dia mais se inspira nos desenvolvimentos de outros campos do conhecimento. Porém, algumas questões 
críticas precisam ser levantadas. Quanto à natureza dessa arquitetura, vale lembrar que o paradigma biológico é, acima de tudo, um paradigma científico, ou seja, carrega todos as limitações analisadas no Primeiro Capítulo desta tese. Muitas vezes, inspirarse na natureza significa, efetivamente, fazer uso da aplicação de algoritmos (equações matemáticas) que tentam explicar aspectos biológicos.

Ainda resta, também, a questão de como essas experimentações estão, efetivamente, produzindo espaços orgânicos e evolutivos em harmonia com seu contexto, ou se estão apenas reproduzindo a tradicional visão moderna do mundo. Quanto ao papel do arquiteto, esses processos, dos quais são catalisadores, são, normalmente, os processos de geração de forma. Nos textos que tratam da arquitetura da era digital, por exemplo, Kolaveric (2003) e Fox e Kemp (2009), pouco é mencionado sobre como os comportamentos das pessoas nesses ambientes construídos são afetivamente influenciados, ou mesmo quais são os parâmetros para a criação de espaços que atuem como catalisadores, depois de construídos.

Se as críticas feitas por LANG et al (1974) forem cruzadas com esses desenvolvimentos, é como se esses novos paradigmas estivessem sendo implementados por arquitetos com uma auto-consciência essencialmente modernista. Não há muitos indícios de que, com esses novos espaços, o arquiteto tenha deixado de ser parte de uma subcultura, ou que não mais generaliza e impõe sua visão de mundo. De maneira geral, falar sobre processos de design, mesmo que este inclua as novas ferramentas de representação e produção ( $C A D / C A M)$, ainda é, na maioria das vezes, falar sobre a relação entre o arquiteto e seu objeto. Mesmo quando o assunto são as arquiteturas interativas, na maioria das vezes, o foco é muito mais em sua lógica interna, quão complexo é seu comportamento (algoritmo) (GLYNN, 2008) ou em questões genéricas de sua coerência externa (FOX; KEMP, 2009).

Talvez isso aconteça, pelo fato de a arquitetura interativa ainda estar em sua infância, ou seja, em sua fase inicial. Consequentemente faltam elementos conceituais e especulativos para abordar as questões relacionadas às especificidades das interações em ação. Nesse sentido, é compreensível que, em um primeiro momento, o foco priorize o entendimento do potencial estético dessas possibilidades. Para essa pesquisa, é nesse espaço que o diálogo com o design de interação pode gerar desdobramentos capazes de enriquecer a prática da arquitetura.

Para o design de interação, questões relacionadas à usabilidade, experiência e apropriação são centrais. Se um produto "falha" em satisfazer aquilo à que ele se 
propõe, dificilmente é levado adiante. Segundo Smith (2007, p. xii) "[...] nossos usuários não são, com razão, preparados para gastar tempo dominando novos sistemas complicados. E eles não são obrigados a usar nossos produtos: se eles não conseguem fazê-los funcionar, eles vão levá-los de volta à loja"197.

Nesse sentido, o produto não é imposto e não considera apenas a visão de mundo daquele que o concebe, ao contrário, seu desenvolvimento é calcado em muita pesquisa sobre comportamento, grupos de interesses e contextos de aplicação, para a identificação de oportunidades que se desdobrem em efetivas apropriações pelas pessoas. Além disso, se a arquitetura pretende ser interativa, faz sentido observar e aprender com o campo do conhecimento responsável por elaborar e sistematizar a criação de produtos interativos como um todo.

\subsubsection{Design de interação}

O design de interação é um campo emergente que surgiu na década de 1990 e que vem ganhando importância na primeira década do século XXI, especialmente com a superação do computador pessoal, marcada pela disseminação de sistemas computacionais, nos mais variados objetos e lugares. Nesse contexto, a função da computação, no cotidiano, não se restringe mais a automatizar ações ou melhorar a eficiência de processos. Ela passa, acima de tudo, a mediar a relação das pessoas com outras pessoas, objetos, ambientes e natureza como um todo. Logo, como Smith (2007, p. xi) aponta, “[...] nós chegamos a uma fase na qual a tecnologia computacional precisa ser projetada como parte da cultura diária, de forma que seja bonita e intrigante, de forma que tenha qualidades tanto emotivas quanto funcionais" ${ }^{198}$.

O design de interação surgiu da preocupação com a criação de um tipo específico de produto, delineado como "[...] o design de tudo que é tanto digital quanto interativo"199 (MOGGRIDGE, 2007, p.660). Nesse contexto, na maioria das vezes, o designer trabalha em equipes multidisciplinares e sua função específica “[...] é a

\footnotetext{
197 Do original em inglês: [...] our users are, justifiably, not prepared to spend time mastering tricky new systems. And they are not obliged to use our products: if they can't make them work, they take them back to the store (SMITH, in MOGGRIDGE, 2007, p. xii).

198 Do original em inglês: [...] we've come to a stage when computer technology needs to be designed as part of everyday culture, so that it's beautiful and intriguing, so that it has emotive as well as functional qualities (SMITH, in MOGGRIDGE, 2007, p. xi).

199 Do original em inglês: [...] a broad definition of interaction design is: 'The design of everything that is both digital and interactive' (MOGGRIDGE, 2007, p.660).
} 
criação de um diálogo entre a pessoa e um produto, serviço ou sistema" ${ }^{200}$ (KOLKO, 2010, p.11). Mais do que responder aos objetivos do cliente, a ênfase é a experiência do usuário, ou seja, daqueles a quem seus produtos se destinam. "Goste ou não, as pessoas e seus objetivos são a finalidade dos nossos sistemas, e nós devemos projetar para elas" ${ }^{201}$ (SMITH, 2007, p. xii).

Para tanto, o design de interação faz uso de diversas metodologias e modos de trabalho que, geralmente, possuem como questão central "[...] entender as pessoas e utilizar protótipos" ${ }^{202}$ (MOGGRIDGE, 2007, p.643). Protótipos entendidos, a partir de uma perspectiva ampla, que inclui as mais variadas formas e recursos utilizados para visualização e comunicação de idéias, desde a construção de modelos físicos à utilização de vídeos ou, até mesmo, a elaboração de diagramas da interação do sistema. Isso confere ao processo uma característica de atividade argumentativa - tal como abordada na introdução deste capítulo - estabelecida tanto entre o designer e as pessoas a quem o produto/sistema se destina, quanto com as representações que utiliza para desenvolver as idéias.

Como aponta Sharp, Rogers e Preece (2007, p. vxii), o design de interação vai além da interação homem-computador - $\mathrm{IHC}^{203}$ - pois “[...] se preocupa com um escopo mais amplo de questões, tópicos e paradigmas" ${ }^{204}$. IHC é a disciplina que se encarrega do design, avaliação e implementação de sistemas computacionais, considerando a usabilidade do sistema e as necessidades humanas (KOLKO, 2010, p. 28). Esse campo consolidou-se, especialmente, com o computador pessoal, dada a necessidade e importância de desenvolver interfaces e funcionalidades "amigáveis" para que todas as pessoas, especialistas ou não, fossem capazes de encontrar alguma utilidade para a máquina e conseguir, efetivamente, usá-la para tal. Nielsen $(1993$, p.8) assim descreve essa transição:

As interfaces de usuários são agora uma parte muito mais importante dos computadores do que costumavam ser. A revolução dos computadores pessoais e a queda dos preços dos hardwares estão tornando os computadores disponíveis para grupos cada vez mais amplos de usuários, e esses usuários estão usando os computadores para uma maior variedade de tarefas.

\footnotetext{
200 Do original em inglês: [...] interaction design is the creation of a dialogue between a person and a product, service or system (KOLKO, 2010, p.11).

201 Do original em inglês: Like it or not, people and their goals are the point o four systems, and we must design for them (SMITH, in MOGGRIDGE, 2007, p. xii).

202 Do original em inglês: [...] understand people and use prototypes (MOGGRIDGE, 2007, p.643).

203 Termo derivado do inglês human-computer interaction - HCI.

204 Do original em inglês: [...] is concerned with a broader scope of issues, topics, and paradigms [...] (SHARP; ROGERS; PREECE, 2007, p.vxii).
} 
Quando os computadores eram utilizados apenas por um pequeno número de pessoas, que em sua maioria realizavam tarefas muito especializadas, fazia sentido exigir um alto grau de aprendizagem e experiência dos usuários. ${ }^{205}$

Porém, inicialmente, mesmo com os usuários em mente, profissionais da área do design eram, normalmente, incluídos no processo de criação do software, apenas, quando todas as decisões sobre a estrutura do sistema já tinham sido tomadas e seu papel se restringia a desenvolver a aparência da interface. Cooper (2003), em meados da década de 1990, foi um dos primeiros a teorizar sobre a importância de se inserir questões e métodos de design, antes da engenharia do sistema, quando decisões sobre seus objetivos e sua estrutura geral ainda podiam ser tomadas. Com a disseminação do poder computacional pelas coisas e lugares, a importância do design passa a ser mais fundamental, pois é ele, acima de tudo, que questiona a validade das intenções do ponto de vista das pessoas.

Por ser bastante dependente de questões tecnológicas, o design de interação está fortemente vinculado a disciplinas destas áreas, tais como a engenharia e a ciência da computação. Porém, sua principal característica deriva da incorporação de toda a tradição criativa de áreas tradicionais do design (gráfico, industrial e arquitetura), junto a possibilidades técnicas e investigações sociais, com o objetivo de trazer questões humanas para a tecnologia. Acredita-se que, assim, seja possível criar experiências convincentes, oportunas e atraentes, e não apenas técnicas. É nesse sentido que o design de interação extrapola o IHC, ampliando suas possibilidades e alargando o pensamento que direciona a disseminação da computação no cotidiano.

Para entender exatamente qual é o produto (resultado) do trabalho do designer de interação, diversas aproximações podem ser estabelecidas. Em geral, esses produtos possuem tecnologia digital em alguma instância, porque é ela que introduz as possibilidades de comportamento com as quais o designer de interações normalmente se ocupa. Moggridge (2007) define três categorias de produtos: experiências baseadas na tela (interfaces gráficas), produtos interativos e serviços. Segundo o autor,

No início das interfaces gráficas para usuários, as habilidades visuais dos designers profissionais eram geralmente aplicadas ao design de ícones, ou às representações visuais de

\footnotetext{
205 Do original em inglês: User interfaces are now a much more important part of computers than they used to be. The revolution in personal computers and falling hardware prices are making computers available to ever broader groups of users, and these users are using computers for a larger variety of tasks. When computers were only used by a small number of people who mostly performed very specialized tasks, it made sense to require a high degree of learning and expertise of the users (NIELSEN, 1993, p.8).
} 
comportamentos, tais como estruturas de janelas ou barras de ferramentas, ou talvez em um nível mais básico de concepção de fontes $^{206}$ (MOGGRIDGE, 2007, p.703).

Aos poucos, o designer passou a atuar no processo de criação da funcionalidade e do comportamento do software, da página da internet e do aplicativo como um todo. Os produtos interativos compreendem os objetos cotidianos que possuem comportamentos implementados com tecnologia digital. Conforme Moggridge (2007, p.715),

Essa é a versão do design de interação na qual o objeto físico é integrado com o hardware e software eletrônico, e as pessoas interagem com aparatos de computação ubíqua, as vezes sem pensar neles como computadores e sim como produtos que são responsivos e inteligentes de alguma maneira. ${ }^{207}$

No design de serviços, a "[...] interatividade acontece entre a empresa e a relação mais ampla com o consumidos, misturando interações baseadas no tempo com múltiplos canais - espaços, produtos, a Web, e assim por diante"208 (MOGGRIDGE, 2007, p.702). Essa faceta do design de interação também é considerada por Saffer (2007, p.175), como a nova fronteira do campo e, assim, destaca sua qualidade sistêmica:

"O design de serviços, como o design de sistemas, foca no contexto - no sistema de uso completo. As pessoa usam produtos (normalmente com outros) em ambientes em processos estruturados. 0 design de sistemas na verdade é o design de todo esse sistema de uso".

É importante enfatizar, também, que essas categorias de produtos não são estanques, são parte de uma estratégia para delinear o campo de atuação. O trabalho do designer de interação é, acima de tudo, criar interconexões entre essas e outras partes, ou seja, contextos para interação entre pessoas, objetos e ambiente.

Dado o escopo da área, o próximo passo é entender seus modos de trabalho, afinal, “[...] a maior contribuição que um designer de interação pode oferecer a um contexto de negócios é um forte processo que conecta pessoas, tecnologia, e as qualidades

\footnotetext{
206 Do original em inglês: In early days of graphical user interfaces, the visual skills of a profesisonal designer were usually applied to the design of icons, or the visual representations of behaviors such as window structures or tool bars, or perhaps at a more basic level to design of typefaces 206 (MOGGRIDGE, 2007, p.703).

207 Do original em inglês: This is the version of interaction design where the physical object is integrated with the electronic hardware and software, and people are interacting with ubiquitous computing devices, sometimes not thinking of them as computers at all but rather as products that are responsive or intelligent in some way (MOGGRIDGE, 2007, p.715).

208 Do original em inglês: [...] interactivity occurs between a company and the broader relationship with the customer, blending time-based interactions with multiple channels - spaces, products, the Web, and so on (MOGGRIDGE, 2007, p.702).
} 
emocionais dos dados sensoriais" ${ }^{209}$ (KOLKO, 2010, p.41). Primeiramente, é importante elucidar o papel das pessoas, aquelas a quem os produtos se destinam, no processo. Porém, não se trata de esboçar fases e associar sua participação com estágios específicos, até porque as pesquisas sobre design já deixaram claro que seu processo nada tem de passo a passo. Mais importante, é perceber a natureza das estratégias que o designer de interação usualmente possui ao seu dispor, e como estas contribuem para a elaboração de critérios relevantes para a elaboração do comportamento dos produtos.

Colocar as pessoas no centro do processo vai além de entender quais são seus requerimentos físicos, perceptivos e cognitivos. Não basta sistematizar e dominar as dimensões do corpo humano ou desvendar como a memória funciona, decisões são tomadas e objetivos alcançados. Pessoas, com toda sua bagagem cultural e emocional, são muito mais que conjuntos simplificados de requerimentos. Levar as pessoas em consideração significa, acima de tudo, abrir-se para outros pensamentos e modos de vida. É estar sinceramente disposto a sair de uma visão autocentrada, a partir da qual designers criam coisas como se estivessem criando para si mesmos, como se outras percepções da realidade não fossem válidas ou possíveis. Desse modo, há de se concordar com Moggridge (2007, p.681) quando afirma que:

É muito difícil ser um bom designer sem ter um grande ego. Afinal de contas, nós tempos que acreditar suficientemente na nossa própria habilidade de sintetizar intuitivamente a solução correta, e ao mesmo tempo admitir que talvez não tenhamos realmente a explicação mais lúcida das razões. Talvez seja por isso que nós achamos muito mais fácil projetar para nós mesmos do que para outras pessoas. $^{210}$

Uma vez que essa intenção de abertura e aprendizado esteja presente, existem diversos métodos e atividades sistematizadas que podem contribuir para a intuição do designer. Muitos desses métodos estão documentados nas method cards (IDEO, 2002), um conjunto de cartões nos quais estão descritos as principais estratégias utilizadas pela empresa IDEO em seus projetos. São 51 cartas, cada uma com um método, seguido de descrição, exemplo e sugestão de aplicação, como mostra a Figura 101102. As cartas são, ainda, divididas em quatro categorias: pergunte, observe,

\footnotetext{
209 Do original em inglês: [...] the major contribution an interacion designer can provide in a business setting is a strong process that connects people, tehcnology, and the emotional qualities of sensory data (KOLKO, 2010, p.41).

210 Do original em inglês: It is very difficult to be a good designer without having a big ego. After all, we need to believe enough in our own ability to synthesize the right solution intuitively, while at the same time admiting that we may not readly have the most lucid explanation of the rationale. That may be why we find it much easier to design for ourselves than for other people. (MOGGRIDGE, 2007, p. 681).
} 
A ideia dos method cards é fazer um grande número de diferentes técnicas serem acessíveis a todos os membros do time de design e encorajar uma aproximação criativa à busca de informações e intuições na medida em que seus projetos evoluem. A intenção é fornecer uma ferramenta que pode ser utilizada flexivelmente para ordenar, navegar, procurar, espalhar e empilhar ${ }^{211}$
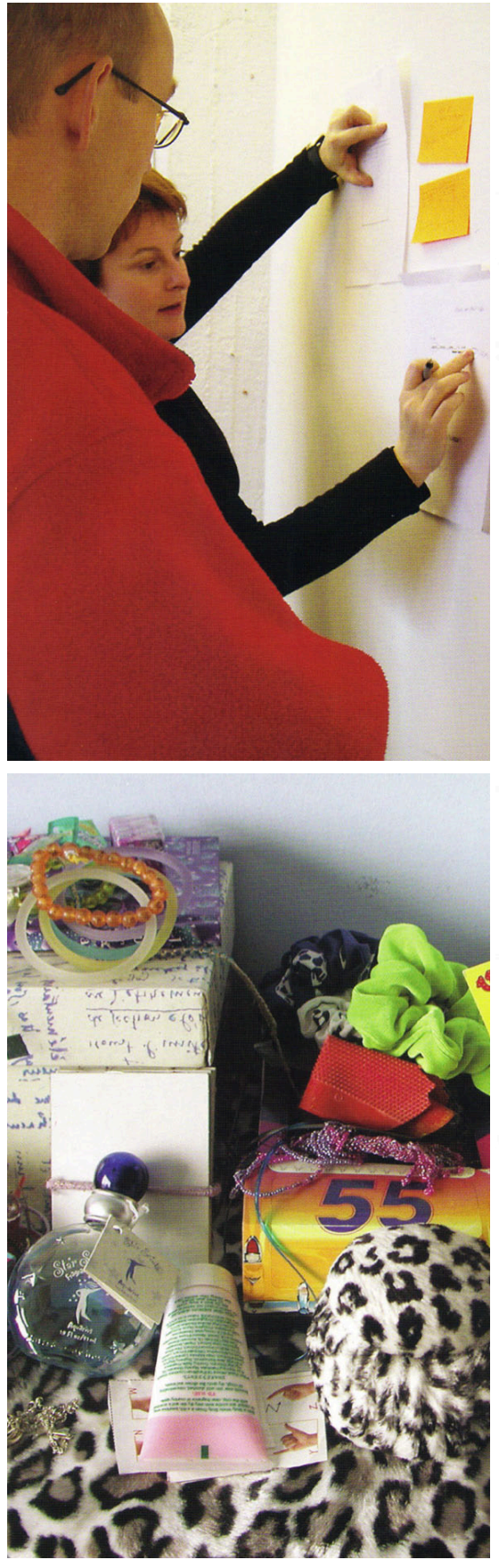

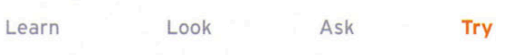

\section{Paper Prototyping}

HOW: Rapidly sketch, layout, and evaluate interaction design concepts for basic usability.

WHY: This is good way to quickly organize, articulate, and visualize interaction design concepts.

Sketching out various screens and testing their sequence helped the IDEO team to demonstrate the locic necessary for a successful interaction with an in-store inventory catabase.

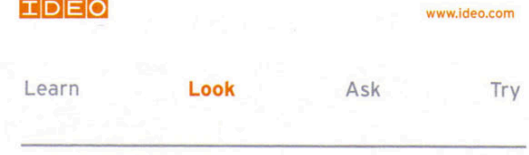

\section{Personal Inventory}

HOW: Document the things that people identify as important to them as a way of cataloging evidence of their lifestyles.

WHY: This method is useful for revealing people's activities, perceptions, and values as well as patterns among them.

For a project to design a handheld electronic device, the IDEO team asked people to show and describe the personal objects they handle and encounter every day.

TIDIEO
Figura 101: Exemplo da IDEO Method Cards, do grupo try (tente) - carta com explicação do método "prototipagem em papel", utilizado para esboçar e avaliar conceitos rapidamente (Fonte: IDEO, 2007)
Figura 102: Exemplo da IDEO Method Cards, do grupo look (observe) - carta com explicação do método

"inventório pessoal", que documenta as coisas que as pessoas acham importantes para entender diferentes modos de vida (Fonte: IDEO, 2007)

211 Do original em inglês: The idea of the methods cards is to make a large number of different techniques accessible to all members of a design team and to encourage a creative approach to the search for information and insights as their projects evolve. The intention is to provide a tool that can be used flexibly to sort, browse, search, spread out, or pin up (MOGGRIDGE, 2007, p. 669). 
Mais importante que os métodos em si, são as ações de abertura que as cartas propõem. Perguntar significa, acima de tudo, convidar outras pessoas a participarem do processo. É admitir para si e para os outros, a importância e relevância do que se tem a dizer sobre o assunto tratado, que existem informações que só elas - as pessoas - saberiam fornecer. Os métodos de observação permitem a descoberta de como as pessoas realmente fazem as coisas, e não como elas dizem que fazem. A experimentação de situações ou a imaginação de cenários, permite o desenvolvimento de maior empatia com as pessoas e conduz à avaliação de soluções, a partir de outros pontos de vista. Para completar esse movimento, é necessário aprender com o processo, ou seja, ser capaz de analisar informações coletadas para identificar padrões e insights para o projeto.

Existem métodos que podem auxiliar cada um desses movimentos, mas eles de nada valem se não forem precedidos da intenção de abertura, ou se forem aplicados apenas para confirmar opiniões e pontos de vista préconcebidos. Os métodos apenas auxiliam nesse deslocamento e não são receitas que garantem resultados, ao contrário, "[...] é normalmente mais valioso aplicar, ou algumas vezes modificar, um conjunto de métodos diferentes para cada projeto"212 (MOGGRIDGE, 2007, p. 669).

A outra importante característica do processo de criação do design de interação, está relacionada às estratégias que utiliza para dialogar com os problemas em questão. $A$ inclusão de pessoas leigas no processo está diretamente ligada a essa natureza argumentativa do processo de design nesse campo, mas essa argumentação vai além. Geralmente, estratégias de prototipagem (MOGGRIDGE, 2007) e esboços (sketching) (SAFFER, 2007), tratam-se de meios de comunicação e externalização do pensamento, assim descritos por Dix e Gongorra (2011, p.31):

Externalização é o passo além, a conformação ativa do mundo como um recurso intelectual, talvez uma capacidade exclusivamente humana e, certamente, a fundação da cultura e civilização. Exteriorização envolve a corporificação, representação e exploração de nossos próprios pensamentos, sentimentos e vida interior. ${ }^{213}$

\footnotetext{
212 Do original em inglês: [...] it is generally most valuable to apply, or sometimes to modify, a range of different methods for any given project (MOGGRIDGE, 2007, p. 669).

213 Do original em inglês: Externalisation is the step beyond, the active shaping of the world as an intellectual resource, maybe a uniquely human ability and certainly the foundation of culture and civilisation. Externalisation involves the embodiment, representation and exploration of our own thoughts, feelings and interior life (DIX; GONGORA, 2011, p.31).
} 
Técnicas e estratégias de externalização perpassam as diferentes áreas do design, cada uma com ênfases distintas. No design de interação, destaca-se a "[...] importância de considerar o papel do tempo e do comportamento na modelagem da experiência em

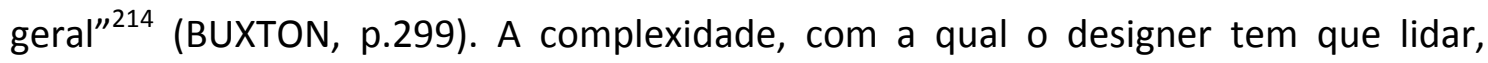
deriva, principalmente, do caráter não-físico de grande parte dos sistemas. Nesse sentido, é a combinação dos mais variados recursos que permite a construção de visualizações que possibilitam o entendimento dessas relações.

Durante o processo de design, o designer de interação procura construir visualizações significativas entre os componentes individuais, em um esforço de compreender as relações ocultas. 0 objetivo final da criação dessas visualizações é compreender. Ao reformular as idéias de maneiras novas e interessantes, o designer pode ganhar uma compreensão mais profunda das ligações abstratas e semânticas entre as idéias. Essas visualizações podem então ser usadas para se comunicar com outros membros da equipe de projeto, ou podem ser utilizadas como plataforma para a criação de esboços generativos ou na produção de modelos. Frequentemente, o ato de diagramar é uma forma de síntese e uma forma ativa de ganhar conhecimento 215 (KOLKO, 2007, p.64).

Nesse sentido, é por meio de modelos, diagramas e documentos que o designer de interação realmente projeta. Mais do que representações, essas estratégias permitem o diálogo do designer com suas idéias. Como aponta Saffer (2007, p.90),

"Os designers usam esses modelos e diagramas para demonstrar sua habilidade, conhecimento e idéias, assim como para visualizar e analisar o que aprenderam anteriormente no processo de design. [...] Cada modelo ou diagrama produzido deve levar o projeto um passo a frente rumo à realização. Esses documentos de projeto são o coração do ofício do design de interação" 216 .

Buxton (2007, p.135) complementa estas considerações, ao afirmar que essa estratégia “[...] tem mais a ver com o exercício da imaginação e do entendimento do

\footnotetext{
214 Do original em inglês: [...] one of the distinctions that we have made between traditional product design and interaction design is the importance of considering the role that time and behavior have in shaping the overall experience (BUXTON, 2007, p.299).

215 Do original em inglês: During the process of design, the interaction designer attempts to construct meaningful visualizations between individual components in an effort to understand hidden relationships. The ultimate goal of the creation of these visualizations is to understand. By reframing ideas in new and interesting ways, the designer can gain a deeper understanding of the abstract and semantic connections between ideas. These visualizations can then be used to communicate to other members of the design team, or can be used as platforms for the creation of generative sketching or model making. Frequently, the act of diagramming is a form of synthesis, and is a way to actively gain knowledge (KOLKO, 2007, p.64).

216 Do original em inglês: Designers use these models and diagrams to demonstrate their skill. Knowledge, and ideas as well as to visualize and analyze what they learned earlier in the design process (SAFFER, p.90).Each model or diagram produced should take the project one step further toward completion. These design documents are at the heart of the craft of interaction design (SAFFER, p.90).
} 
que com os materiais utilizados. [...] A importância dos esboços está na atividade e não no artefato resultante" ${ }^{217}$. Todo esse destaque em relação aos meios utilizados para desenvolver os projetos advém da tendência dos designers, a quererem trabalhar diretamente com a mídia final do projeto, sem levar em conta que outros materiais podem ajudá-los a experimentar com as restrições básicos da usabilidade e valor percebido (MOGGRIDGE, 2007).

Segundo Kolko (2007), são os diferentes tipos de visualização que permitem ao designer desenhar com a quarta dimensão. Tanto maneiras mais abstratas de representação como os diagramas de fluxos ou mapas conceituais, quanto aquelas mais contextualizadas como histórias em quadrinhos ou cenários futuros, podem ser bastante úteis como meio de modelar o comportamento ao longo do tempo. Afinal, no design de interação não basta criar o objeto, é necessário, também, levar em consideração o diálogo a curto, médio e longo prazo com o produto, incluindo, aí, tanto a necessidade de atualizações, quanto as possibilidades de usos e desusos do produto.

A lógica interna e a coerência externa do comportamento são, normalmente desenvolvidas, simultaneamente, em um processo de retroalimentação constante. Isso é essencial, já que “[...] as tecnologias que nós criamos não existem, e nunca irão, em um vácuo. Em qualquer sentido possível, elas só tem significado ou relevância em um contexto físico e social. E, cada vez mais, esse contexto social é com relação a outros dispositivos, assim como pessoas" ${ }^{218}$ (BUXTON, 2007, p.32). Deste modo, um dos principais papéis do designer de interação é ampliar o campo de consideração do problema, incluindo tanto o produto quanto o ecossistema do qual fará parte.

Essas aproximações que extrapolam a lógica interna do produto são importantes não apenas para gerar informações para o projeto, como aponta Moggridge (2007, p. 707), mas podem também desvendar possibilidades, pois, “[...] quando voltamos para o básico da experiência da pessoa como um todo e pensamos sobre o que acontece do início ao fim, é comum encontrarmos áreas de oportunidades de design"219. Para que

\footnotetext{
217 Do original em inglês: It [sketching] has more to do with exercising the imagination and understanding (mental and experimental) that about the materials used. [...] The importance of sketching is in the activity, not the resulting artifact (BUXTON, 2007, p.135).

218 Do original em inglês: [...] the technologies that we design do not, and never will, exist in a vacuum. In any meaningful sense, they only have meaning, or relevance, in a social and physical context. And increasingly, that social context is with respect to other devices as well as people (BUXTON, 2007, p.32).

219 Do original em inglês: [...] when we go back to the basics of the experience that a person has as a whole and think about what happens form start to finish, we often find areas of design opportunity (MOGGRIDGE, 2007, p.707).
} 
tudo isso aconteça, diversas estratégias podem ser adotadas, algumas são, assim, resumidas por Saffer (2007, p.90):

\begin{abstract}
"Modelos das pesquisas mostram o que foi aprendido nas pesquisas com usuários. Personas demonstram uma compreensão da audiência. Casos de usos e análises de tarefas delineiam o que o produto ou serviço precisa realizar. Quadros de humor, cenários, sotryboards, fluxos de tarefas, esboços, wireframes e protótipos juntam todas as peças, em uma visão do que o produto ou serviço final será. Os testes garantem que essa visão seja compartilhada pelos usuários."220
\end{abstract}

Em relação à aplicação dessas técnicas, Buxton (2007, p.201-202) alerta que “[...] se perdermos de vista a interdependência das várias habilidades que compõem o todo, nós provavelmente iremos falhar". Não se tratam de receitas a serem seguidas e, sim, técnicas que, dependendo de como forem adaptadas e adotadas para cada caso, complementam umas às outras e podem vir a melhorar a capacidade dos designers de explorar idéias. "Em conjunto, tudo isso serve o propósito de propiciar, incentivar, e enriquecer as conversas que temos com nós mesmos, nossos esboços, nossos colegas e nossos clientes." ${ }^{221}$

Colocadas as principais questões referentes ao processo criativo do design de interação, algumas ressalvas precisam ser feitas. $O$ aspecto focalizado nesta pesquisa, evidenciou, especificamente, os métodos e estratégias de criação adotados por este campo emergente. Todavia, não incluiu em seu escopo analisar, criticamente, a natureza dos produtos resultantes, isso já seria, certamente, conteúdo para uma outra tese. Contudo, cabe observar que se tratam de produtos tecnológicos, o que faz com que se incorporem todas as questões e ambigüidades tratadas no Primeiro Capítulo. Abster-se dessa visão crítica, significa reafirmar os valores hegemônicos. Assim, além de pensar nas estratégias e etapas que envolvem o processo criativo, é importante inserir as criações nos diversos outros contextos com os quais dialogam e explicitar os pressupostos, valores e visão de mundo que sustentam.

Por fim, exploradas as especificidades de cada área, a próxima etapa deste trabalho, é ilustrar possibilidades de diálogo entre elas. Isso será feito com o intuito de abrir

\footnotetext{
220 Do original em inglês: Research models show what was learned from the user research. Personas demonstrate an understanding of the audience. Uses cases and task analyses outline what the product or service needs to accomplish. Mood boards, scenarios, storyboards, task flows, sketches, wireframes, and prototypes pull all the pieces together into a vision of what the final product or service will be. Testing makes sure that that vision is shared by the users (SAFFER, 2007, p. 90).

221 Do original em inglês: Taken together, all this serves the purpose of affording, encouraging, and enriching the conversations that we have with ourselves, our sketches, our colleagues and our clients (BUXTON, p.201, 202).
} 
caminhos para o estabelecimento dessa relação. Essa aproximação é conduzida, a partir da análise de projetos específicos que, cada um da sua maneira, ilustram oportunidades de incorporação de alguns princípios e estratégias do design de interação, pela arquitetura. Tratam-se de oportunidades de desenvolvimento de projetos que apareceram, durante a realização desta pesquisa, e que foram encarados como chances de verificar, na prática, algumas questões.

\subsection{Arquitetura e interatividade}

As análises feitas, mostraram que a difusão da tecnologia digital, na vida cotidiana, tem incidido na arquitetura de diversas maneiras. Isso acontece, por exemplo, com as novas ferramentas de criação e produção de espaços, na introdução de sistemas digitais de gerenciamento urbano, na incorporação de sensoriamento nos edifícios e, também, no crescente número de aparatos digitais carregados pelas pessoas. Tudo isso, tem mostrado um grande potencial no que se refere à conformação da experiência urbana e social humana. Por outro lado, como alerta Greenfield (2013), se arquitetos e urbanistas não se colocarem como protagonistas da criação e adaptação desses sistemas, corre-se o grande risco de as empresas desenvolvedoras, desses sistemas, tornarem-se responsáveis por diversas decisões que podem incidir, diretamente, na conformação das cidades e da vida das pessoas.

Muito já tem sido discutido sobre o impacto dos softwares e das tecnologias de produção e fabricação digital, na arquitetura. Portanto, a perspectiva colocada por esta pesquisa tem como objetivo acrescentar outras perspectivas a esse contexto, indicando possibilidades de aplicação de estratégias de criação do design de interação na arquitetura interativa. Para isso, a partir dessa perspectiva, são analisados três projetos que indicam oportunidades relevantes de troca entre as áreas. Isso é feito, acima de tudo, para chamar a atenção dos dois campos para a necessidade de estratégias comuns e de troca para tratar questões relacionadas à tecnologia digital no ambiente construído.

O Ambiente Interativo D3 é um dos principais produtos desta pesquisa, pois nele foi possível incorporar em todo seu processo de design, importantes questões referentes ao design da arquitetura interativa. Trata-se de um escritório projetado, em parceria com um estúdio de arquitetura, para clientes reais, o que faz dele um fértil campo de exploração e aplicação de estratégias experimentais. Além disso, durante a vigência da pesquisa, foi possível completar a obra e, após um ano, conversar com um dos clientes sobre o que aconteceu uma vez que o espaço foi concluído. 
Os projetos Low2No e FredericiaC+ são exemplos significativos das possibilidades de diálogo entre as práticas da arquitetura e do design de interação. Trata-se de dois projetos de desenvolvimento urbano, com aproximações semelhantes, desenvolvidos, a partir da parceria de escritórios de engenharia, arquitetura e design de interação. $A$ análise desses projetos é feita a partir dos documentos das propostas, de entrevistas com envolvidos nos projetos e da vivência direta no processo de design do segundo (Fredericia $\mathrm{C}+$ ), como parte da equipe do escritório de design de interação.

\subsubsection{Ambiente Interativo D3}

O ambiente interativo analisado neste trabalho, foi projetado para ser sede de uma produtora digital, empresa que trabalha em conjunto com agências de publicidade para produzir aplicativos e websites (Figura 103). O fato de ela trabalhar com diferentes mídias estimulou a concepção de um espaço que refletisse, ao máximo, as atividades e processos criativos que ali ocorrem. Deste modo, sua criação sobrepôs a presença da interação e o desenvolvimento de seu sistema, ao desenho das formas, à escolha das cores e dos materiais que compõem o espaço. Seu processo de design, já analisado em outras ocasiões (CARNEIRO et al, 2011a ; CARNEIRO et al, 2011b), ilustra diversas questões específicas do design da arquitetura interativa, que podem servir de insumos para outros projetos.

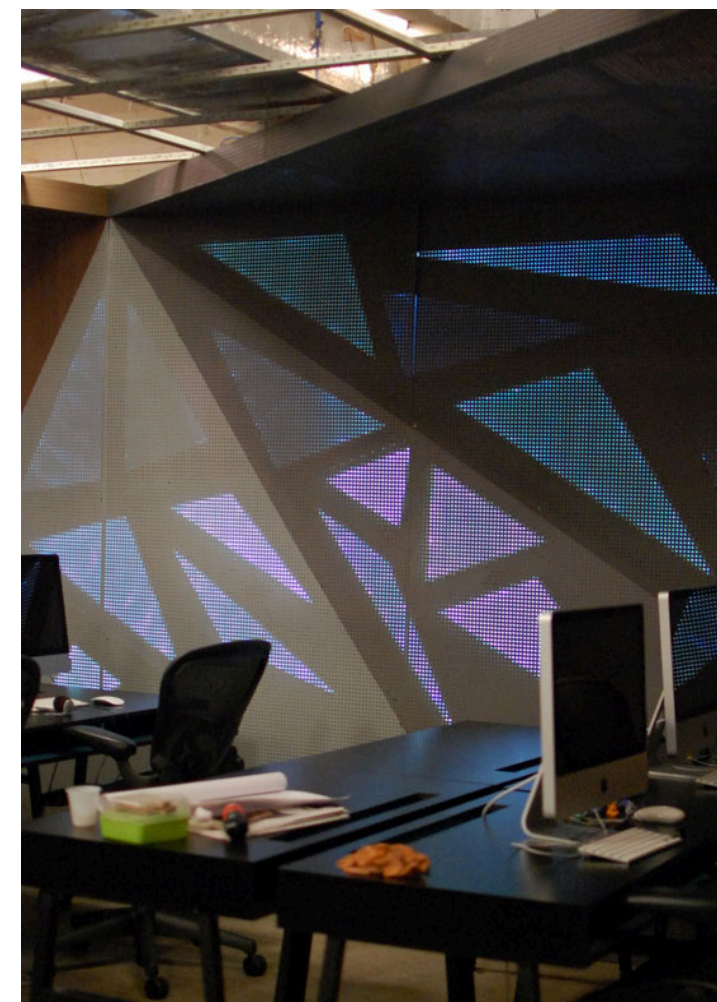

Figura 103: Ambiente Interativo D3 (Fonte: Gabriela Carneiro)
Procurou-se, acima de tudo, elaborar uma aproximação holística na qual a tecnologia digital, enquanto meio de expressão, esteve presente desde o início. A partir das informações inicialmente fornecidas pelos clientes, desde os primeiros esboços, já foram previstos padrões luminosos em uma das laterais, com um desenho que seguia a linguagem adotada para toda a marcenaria do projeto, com base em triangulações irregulares. Os padrões forma compostos por 25 triângulos luminosos, visíveis apenas quando acesos. Em alguns momentos, optou-se por deixar aparentes aspectos da 
infraestrutura do espaço, na qual foram conectados os sensores que captam informações sobre as atividades que ali ocorrem.

A intenção era conceber um ambiente que explorasse diversas camadas de interação. Da mesma forma que as pessoas alteram propriedades físicas do espaço, por meio de sua movimentação, elas passam, também, a entender um pouco mais dos hábitos e atividades que ali ocorrem. Além disso, trata-se de um comportamento que pode ser aberto e redesenhado, o que transforma o espaço em um plataforma de experimentação. Para isso, foi disponibilizada uma biblioteca de comandos que permite o desenvolvimento futuro de outras possibilidades interativas pelos clientes e usuários.

Como a essência do projeto incluía a futura apropriação criativa do espaços pelas pessoas que ali trabalham, a participação destas, foi essencial, durante a concepção e desenvolvimento do projeto. Para compreender as possibilidades de participação, foram utilizadas diversas referências do design de interação, em especial para a elaboração de um workshop criativo, organizado com o objetivo de

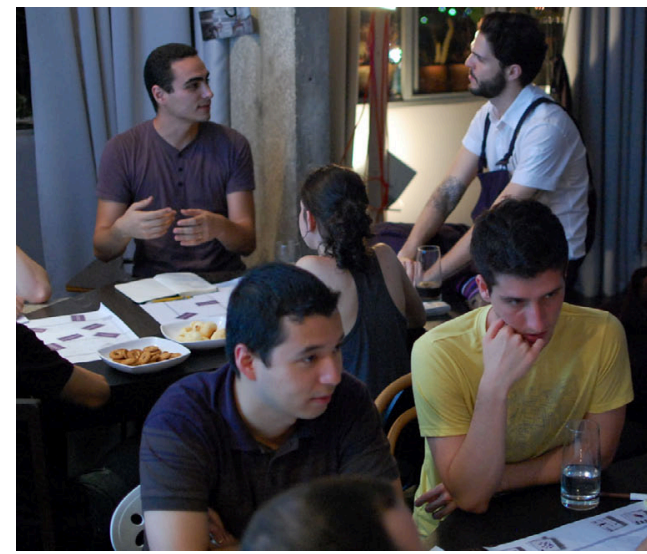

Figura 104: Workshop colaborativo realizado durante 0 processo de design do Ambiente Interativo D3 (Fonte: Gabriela Carneiro) gerar insumos para a finalização conceitual do projeto (Figura 104). Um dos motivos para a realização dessa atividade, foi a falta de referências sobre este tipo de arquitetura, o que, normalmente, gera inúmeras incertezas nos momentos de tomadas de decisões. Contudo, a principal intenção, foi levantar informações relevantes sobre as atividades da empresa bem como das expectativas de clientes e usuários sobre a apropriação do espaço.

Com a parede de triângulos (output) já instalada, o principal objeto de discussão foram os sensores que seriam utilizados para captar as informações (input) e o comportamento, ou seja, como os dados afetariam os triângulos luminosos. O workshop foi uma atividade única, controlada, e com a duração de uma hora e meia. Além do mediador, o workshop contou com a presença de dois representantes dos clientes (usuários), dois funcionários da empresa (usuários), três arquitetos, um engenheiro elétrico e dois pesquisadores convidados, perfazendo um total de 10 participantes, distribuídos em dois grupos homogêneos. O dois grupos foram 
formados, com a preocupação de equilibrar as funções que os participantes exercem no projeto como um todo.

Como parte das atividades realizadas no workshop, os dois grupos discutiram sobre o espaço, os comportamentos e os hábitos das pessoas, relacionando estes com possíveis sensores e com as interações que poderiam acontecer no ambiente. Como material de suporte, foram utilizadas plantas do espaço na escala 1:50, juntas com as i/o cards (CARNEIRO, 2012), um conjunto de cartões desenvolvido para estimular a conversação e troca de ideias durante a concepção de sistemas interativos.

As i/o cards são divididas em dois grupos: um trabalha questões estruturais do sistema interativo e o outro aborda algumas preocupações conceituais necessárias para a criação de experiências interativas. O primeiro grupo contém representações gráficas do microcontrolador e dos principais sensores-atuadores que um iniciante em computação física precisa conhecer, com a indicação do tipo de informação que fornecem (analógica ou digital), conforme apresentado na Figura 105. O segundo grupo possui, em uma de suas faces, os conceitos importantes para o desenvolvimento de comportamentos interativos focados na experiência das pessoas, e, na outra face, breves explicações destes conceitos (Figura 106). Para este workshop, o grupo conceitual foi adotado, na sua totalidade, enquanto o das cartas estruturais apenas os sensores foram utilizados, de forma que as representações dos atuadores e o microcontrolador foram deixados de lado.

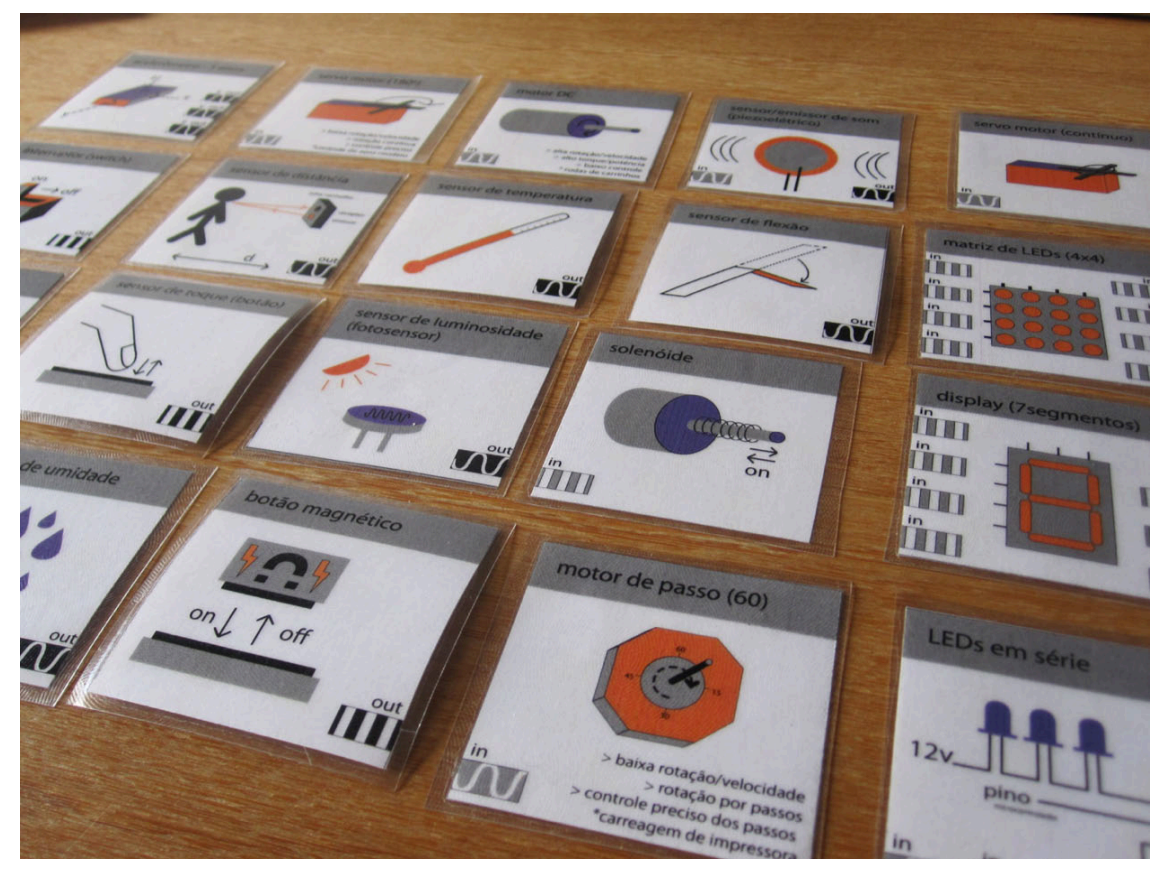

Figura 105: Cartas estruturais das ilo Cards (Fonte: Gabriela Carneiro) 


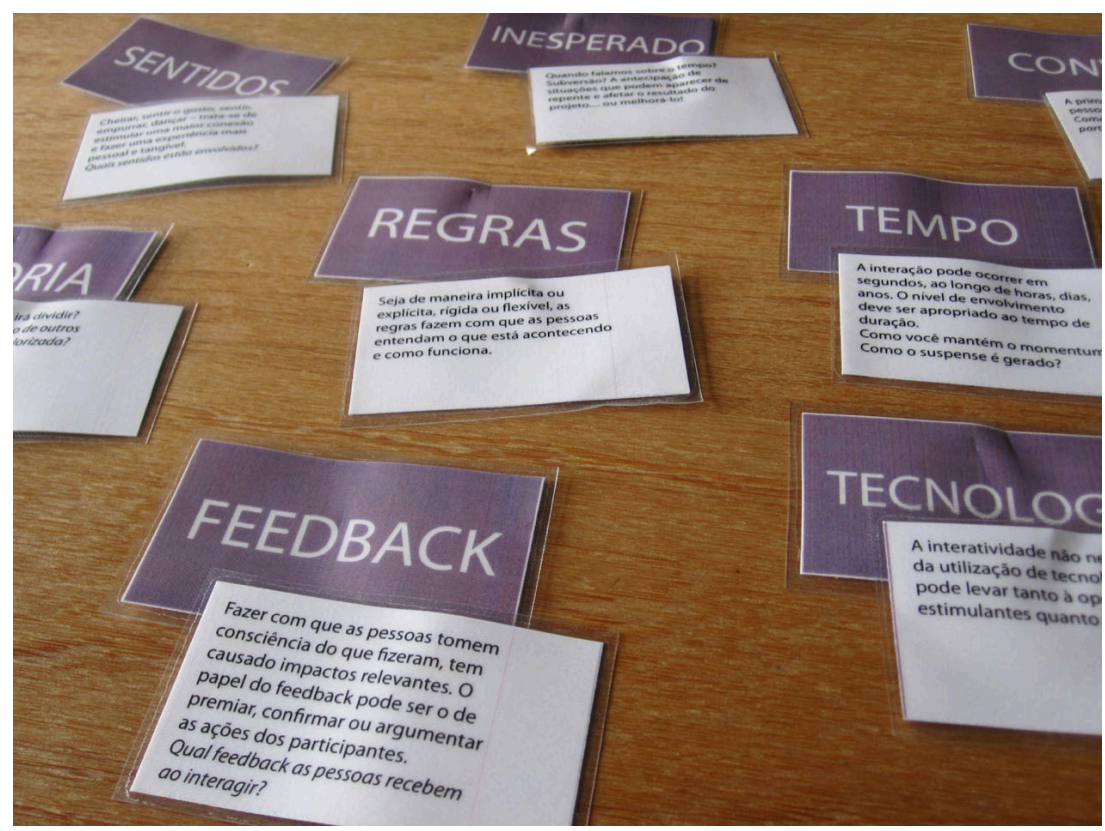

Quanto à dinâmica do workshop, ilustrada da Figura 107, ambos os grupos começaram com as plantas em mãos. As cartas foram, então, distribuídas de maneira alternada sendo que o Grupo 1 começou a atividade com os elementos estruturais (no caso, apenas os sensores), e o Grupo 2 com os conceituais. Após 15 minutos, o restante das cartas foi distribuído para os dois grupos. Desse modo, um grupo foi forçado a começar a discussão pela questão técnica e o outro pela experiência.

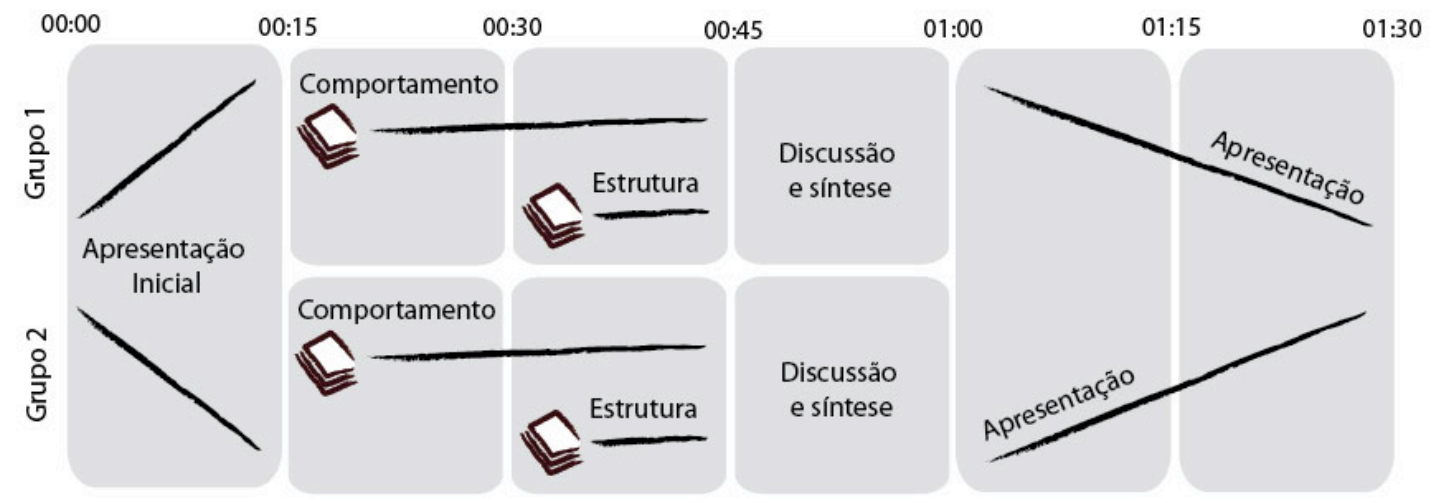

Figura 107: Gráfico com dinâmica do workshop (Fonte: Gabriela Carneiro)

Após 30 minutos de discussão, os grupos tiveram um tempo para organizar as idéias e finalizar a atividade com a apresentação das mesmas, seguida de uma discussão coletiva. No final da sessão, com o intuito de avaliar a atividade, foi requisitado aos participantes que redigissem e enviassem por e-mail sua impressão individual sobre o workshop.

Como resultado, a dinâmica adotada para o workshop possibilitou uma discussão aprofundada, em um tempo relativamente curto, de diferentes possibilidades para o ambiente. As principais ideias foram sintetizadas pelos próprios participantes e 

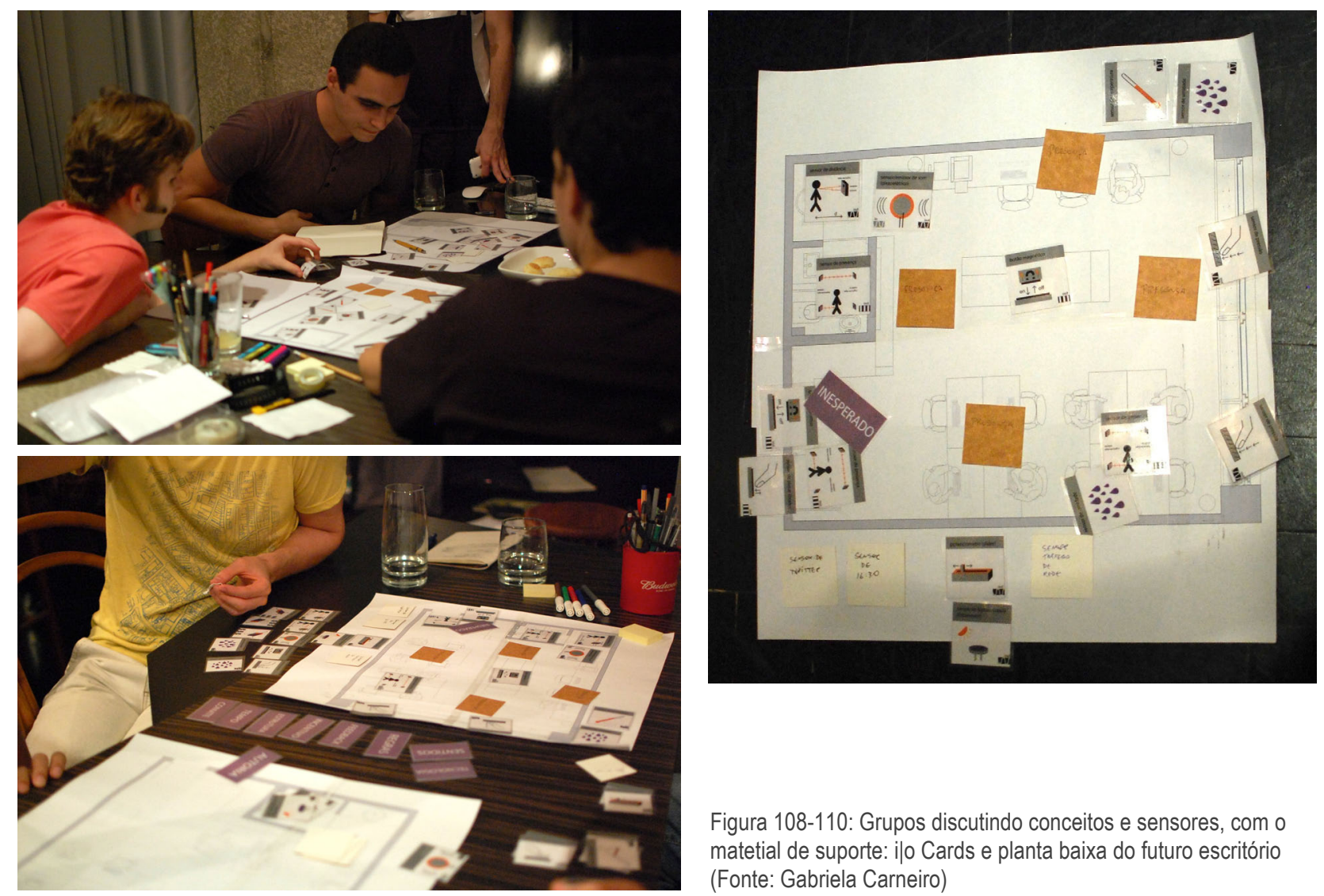

Figura 108-110: Grupos discutindo conceitos e sensores, com o matetial de suporte: ilo Cards e planta baixa do futuro escritório (Fonte: Gabriela Carneiro)

apresentadas no momento final. Para servir de input para o projeto, esta apresentação foi gravada e, em seguida, integralmente transcrita. As ideias foram então sintetizadas e utilizadas para a definição do comportamento padrão do sistema.

Após a análise das informações obtidas durante workshop, foram definidos os sensores a serem instalados no espaço e sua localização, assim como o comportamento padrão a ser implementado. Além dos 25 triângulos luminosos, o sistema interativo contou, também, com seis sensores ultrasônicos instalados, na estrutura do teto, um microfone na proximidade da cozinha e um sensor para captar a abertura e fechamento da porta de entrada. O comportamento foi implementado em linguagem PHP e pode ser tanto alterado quanto substituído por outros algoritmos, desenvolvidos pelos próprios usuários.

O comportamento padrão utiliza os sensores ultrasônicos de distância, dispostos na estrutura do teto. São oito sensores que captam nuances da movimentação das pessoas pelo espaço, e fazem com que a parede emita diferentes padrões luminosos, ao longo do dia. Por se tratar de um tipo de informação periférica, presente durante o dia inteiro, fez-se necessário o desenvolvimento de um padrão suave e discreto. 
Os triângulos luminosos respondem, também, a dois eventos. O primeiro é a entrada e saída de pessoas no espaço, sendo que, toda vez que a porta é aberta ou fechada, um padrão específico é acionado. Uma vez que as pessoas da empresa cultivam um hábito diário de parar para tomar café, todos ao mesmo tempo, o som captado na copa é também interpretado, gerando um padrão mais dinâmico, que representa a interação entre as pessoas.

De modo geral, o workshop englobou questões, que vão muito além dos insumos para a criação de um comportamento padrão, previsto como parte do espaço, na proposta inicial do projeto. Dentre outras constatações, é importante ressaltar seu papel de gerador de insumos para a definição de um comportamento calcado no uso efetivo do espaço. Neste sentido, fica claro que convidar pessoas para participar do processo criativo, não significa dizer que eles irão definir questões e, sim, que eles gerarão dados a serem posteriormente considerados pelos designers responsáveis. Como Lawson (2005) afirma, é muito importante compreender as demandas reais dos usuários de um sistema ou ambiente.

Neste projeto, o workshop teve, ainda, um papel fundamental em relação ao futuro deste espaço. Uma vez que uma das características do sistema interativo, desenvolvido para este espaço, é a possibilidade de intervenções futuras por meio de sua reprogramação, o workshop gerou insumos tanto para os arquitetos quanto para os próprios usuários. Ideias específicas que não foram, inicialmente, implementadas, puderam estimular futuras intervenções.

É importante ressaltar, que o desenvolvimento de um sistema interativo aberto - que prevê a possibilidade de alteração - foi uma resposta elaborada, pelos arquitetos, ao perfil dos clientes e usuários, cujas habilidades incluem a programação de websites e notável abertura para experimentações com a tecnologia digital. Aqui a arquitetura vai além de seu papel de invólucro e, o próprio espaço, atua como estimulador de atividades criativas e trocas entre seus usuários.

A participação dos clientes e usuários, no processo de design, por meio do workshop, promoveu também o sentimento de apropriação do espaço pelos mesmos. Um dos participantes, relatou que "[...] no final, minha própria percepção do projeto geral amadureceu bastante e agora estou mais empolgada do que antes"222. Dado o caráter inovador da proposta, a dinâmica auxiliou no processo de entendimento e aumentou a

222 Relato informal enviado por e-mail, por um dos participantes, após o workshop. 
consciência e conhecimento das pessoas que irão usufruir desta espacialidade, no que diz respeito às possibilidades ali presentes.

Outro aspecto a ser considerado, é o subsídio da dinâmica para ampliar o repertório conceitual e prático dos participantes em geral. O grupo heterogêneo - de clientes/usuários, arquitetos e pesquisadores - forneceu uma base ampla e mista que contribuiu nitidamente para o enriquecimento das discussões colocadas. Sobre esse ponto, outro participante relatou: "[...] acredito que tudo isto produziu um número incrível de ideias e de ideias para outras ideias." ${ }^{223}$

A utilização de material de suporte foi um aspecto essencial para o resultado positivo do workshop. As cartas e plantas permitiram a experimentação prática do processo de design, de um espaço interativo, assim como abriram a oportunidade para diversos outros questionamentos e ações. Por outro lado, também teria sido interessante a utilização de suportes materiais para exploração dos padrões luminosos do conjunto de triângulos. Em um dado momento, o Grupo 2 chegou a esboçar estes padrões em um papel, o que constata que pensar em maneiras de facilitar e tornar tangível, também, este estudo, teria contribuído ainda mais, com o resultado final.

Depois de um ano da entrega do espaço, foi feita uma entrevista com um dos clientes/usuários na qual diversos tópicos sobre o processo e o produto final foram abordadas. Na primeira parte, foram colocadas questões sobre o significado do espaço para a empresa, dentre elas, como normalmente se referem ao espaço e quais são suas principais possibilidades e limitações. Na sequência, questões específicas sobre seu processo de criação foram contempladas. Por fim, foi explorado seu papel enquanto plataforma de experimentação, como até que ponto essa intenção foi efetivada.

Em relação ao significado do espaço, destaca-se a forma como ele é utilizado para exemplificar o tipo de trabalho que o escritório desenvolve, assim explicitado por Pavoni (2013, n.p.), designer e diretor criativo da empresa:

Hoje quando estou em uma reunião, falo: está vendo isso aqui, é nosso espaço e essa parte sem forro tem vários sensores, e essa parede tem um comportamento luminoso que, de acordo com o comportamento das pessoas na sala, ele se altera. Então a sala acaba explicando bem o que a D3 faz para as pessoas. As pessoas falam, ah, que legal, olha como vocês são. E é isso mesmo, esse é o

\footnotetext{
223 Relato informal enviado por e-mail, por um dos participantes, após o workshop.
} 
tipo de projeto que agente faz, esse é o tipo de coisas que agente faz. Coisas que são interativas e que ao mesmo tempo as pessoas usam.

Sobre questões específicas do workshop, o designer destaca, além do material de suporte, a diferença feita pela inclusão de pessoas que não faziam parte do grupo dos principais interessados pelo projeto - neste caso, outros funcionários do escritório e pesquisadores interessados sobre o tema. Para Pavoni (2013), isso foi essencial para configurar aquele como um momento de troca e criação, e não apenas uma reunião de projeto. A representação gráfica das possibilidades de sensoriamento e o formato das cartas foram apontados como diferenciais importantes.

A principal informação que a entrevista forneceu, foi em relação da utilização do espaço como plataforma de experimentação, sobre a qual Pavoni (2013) descreve três categorias de apropriação do sistema. A primeira concerne experimentos rápidos e funcionais (testes), relacionados a outros projetos em andamento no escritório. Nesse caso, por exemplo, pelo fato do sistema estar conectado na internet (possui um API), ele é utilizado para testar aplicações que precisam funcionar remotamente, para checar se as instruções realmente funcionam.

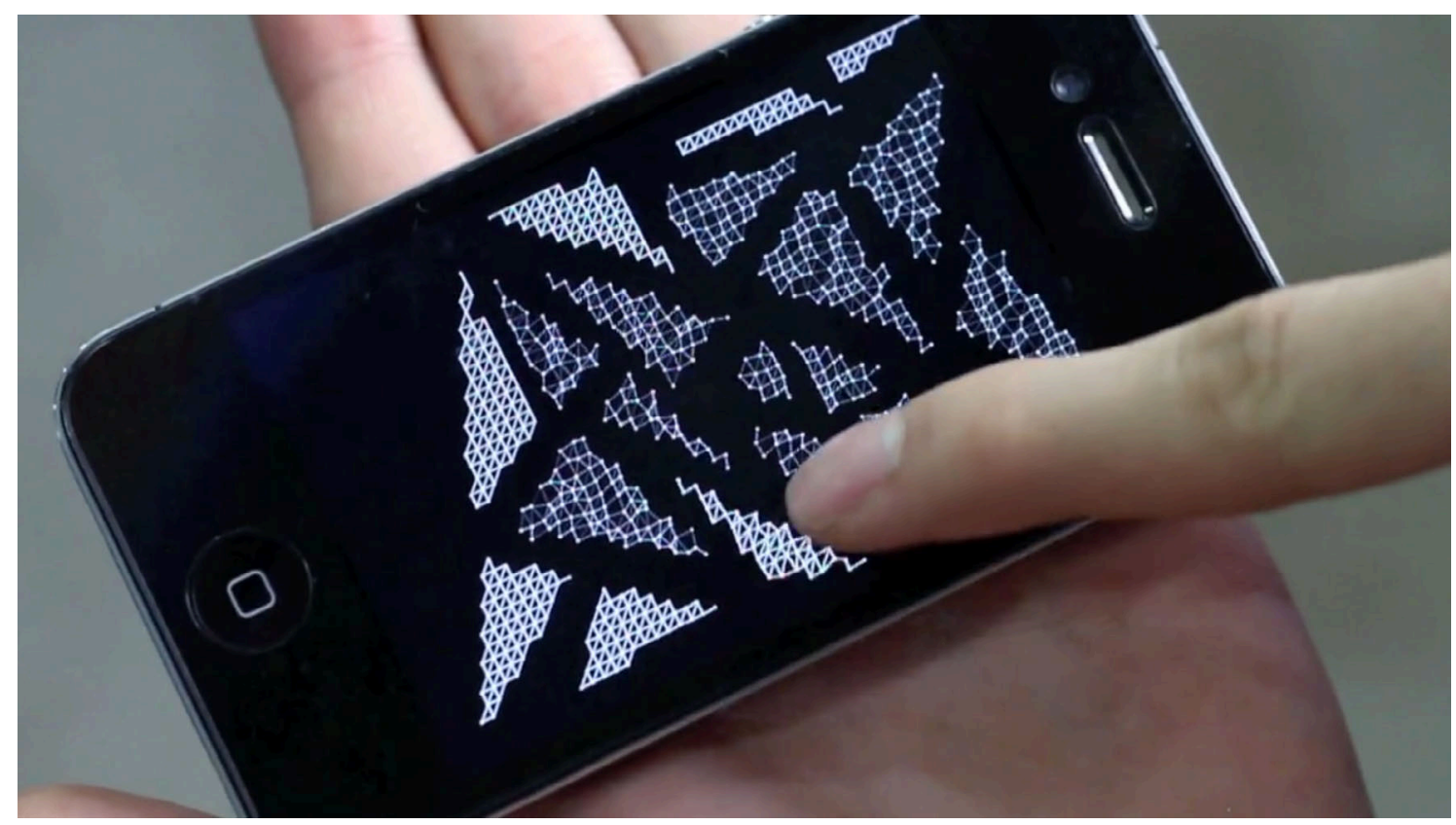

Figura 111: Aplicativo desenvolvido pela empresa, que permite o controle dos triângulos luminosos por meio de um aplicativo para cellular (Fonte: D3 Produtora Digital)

A segunda categoria de uso envolve o desenvolvimento de protótipos e aplicativos, para nutrir o portfólio da empresa. Isso aconteceu, por exemplo, quando começaram a desenvolver aplicativos para iPhone. Para praticar e ilustrar esse novo campo de 
interesse, foi desenvolvido um aplicativo que permite enviar, remotamente, por meio dos aparelhos, animações que são reproduzidas nos triângulos luminosos.

O terceiro tipo de uso está relacionado a prática constante da empresa, de formar profissionais especializados na área. Para isso, estagiários ficam, por seis meses, participando de projetos, aprendendo com os outros profissionais e desenvolvendo experimentos próprios para colocar em prática o que foi aprendido. Uma vez pronto o espaço, uma das tarefas desses estagiários passou a ser criar, livremente, aplicações utilizando os recursos do espaço (Figura 112).

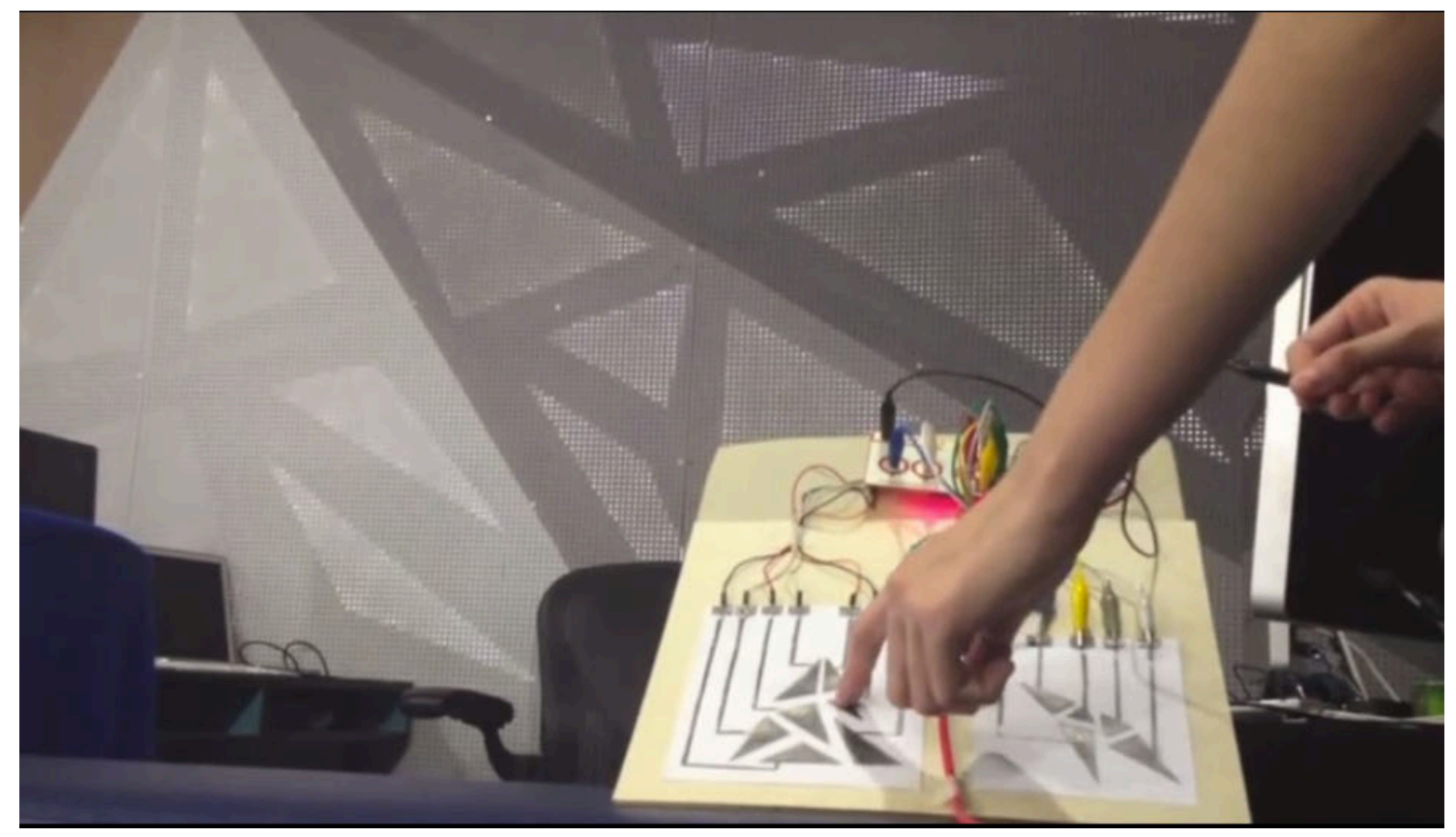

Figura 112: Esperimento realizado por estagiários utilizando o espaço (Fonte: D3 Produtora Digital)

Além dessas informações, do relato de Pavoni (2013), podem ser extraídas também, pontos nos quais o projeto deixou a desejar. De modo geral, as críticas estão relacionadas à lógica interna do sistema implementado. Em primeiro lugar, há de se destacar a fragilidade do comportamento implementado, o qual constantemente trava o sistema e é preciso reiniciá-lo. Por outro lado, Pavoni (2013) acrescenta que a base do sistema é extremamente robusta e confiável:

O que aconteceu é que a parte que está bem desenvolvida funciona $100 \%$ e agente usa bastante. A parte que ficou médio desenvolvida, quer dizer, funcionou um mês e depois teve seus problemas, ela deixou de ser usada. Então se tem uma coisa que eu diria que é critico para esse projeto, é isso. Você tem que pensar em quanto tempo vai durar, porque a implementação de baixo nível ficou excelente. Agente muda e faz várias mudanças e ela continua funcionando, ela tem vários mecanismos para ser 
reiniciada e tal. Ela realmente é bem segura. A implementação por cima disso ficou assim, é aquela coisa que funcionou no evento mas não foi pensada pra funcionar para sempre.

Outra questão crítica, foi a escolha das funções, criadas para o desenvolvimento de outras interações com o espaço. Pavoni (2013) afirma que, nesse aspecto, faltaram funções básicas de animação que poderiam ter sido explicitadas caso, houvesse mais trocas sobre essas questões. Contudo, apesar das críticas, as questões mencionadas pelo designer (2013), confirmam várias intenções iniciais e práticas adotadas pelo projeto, além de indicar pontos importantes a serem revistos.

Do ponto de vista de quem se envolveu com todo o processo, especialmente no desenvolvimento do sistema interativo, outras questões críticas também podem ser destacadas. A primeira foi a dedicação conferida à construção do sistema que, nesse caso, foi muito maior do que o tempo despendido com a implementação do comportamento final. Isso ocorreu, em parte, pela grande quantidade de trabalho manual realizado para sua construção. Talvez, sistemas pré-prontos e adaptáveis para o espaço, poderiam ajudar a equalizar o tempo de desenvolvimento e implementação da estrutura e do comportamento. Contudo, é importante lembrar que, para isso, não são suficientes os atuais sistemas de automação residencial. Ao contrário, fazem-se necessárias soluções que, apesar de pré-concebidas, ainda permitam sua adaptação e a utilização da tecnologia digital, enquanto meio de expressão dos conceitos do espaço.

Além dessas questões técnicas, é também relevante destacar que, fundamentalmente, esse tipo de proposta só se completa quando se constata a apropriação de suas possibilidades por aqueles para quem o projeto foi destinado. Para que isso ocorra, além da solução representar bem seu contexto, são necessárias estratégias que envolvam as pessoas e as conduzam a se imaginar no cenário proposto e se identificar com o espaço que está sendo desenvolvido. Nesse sentido, a arquitetura interativa não é essencial para a vida humana, mas pode ser um recurso interessante quando utilizado, coerentemente, para refletir contextos e intenções específicas.

\subsubsection{Low2No e FredericiaC+}

Os projetos Low2No (2010) e FredericiaC+ (2011) são propostas de desenvolvimento urbano que resultaram, nos dois casos, da parceria entre escritórios de engenharia, arquitetura e design de interação. Dessa maneira, é a presença do design de interação como parte da equipe de projeto que os tornam relevantes para a análise proposta pelo presente trabalho. Como insumos foram utilizados: os documentos dos projetos 
disponíveis online $e^{224}$, as conversas e as entrevistas com pessoas envolvidas nas propostas bem como a experiência prática de vivência e participação, durante seis semanas, na finalização do FredericiaC+ como integrante da equipe do escritório de design de interação.

Nesses dois projetos, a aproximação com as questões levantadas pelas propostas e as estratégias utilizadas foram semelhantes e complementares, o que faz com que sejam tratados em um mesmo tópico. Em ambos os casos, as equipes foram lideradas pelo escritório de engenharia, que escolheu os arquitetos (diferentes em cada projeto) e identificou a oportunidade de incluir, no grupo, profissionais do design de interação. Trata-se de propostas de desenvolvimento urbano, em diferentes escalas e com objetivos distintos, com questões de sustentabilidade como fio condutor dos discursos.

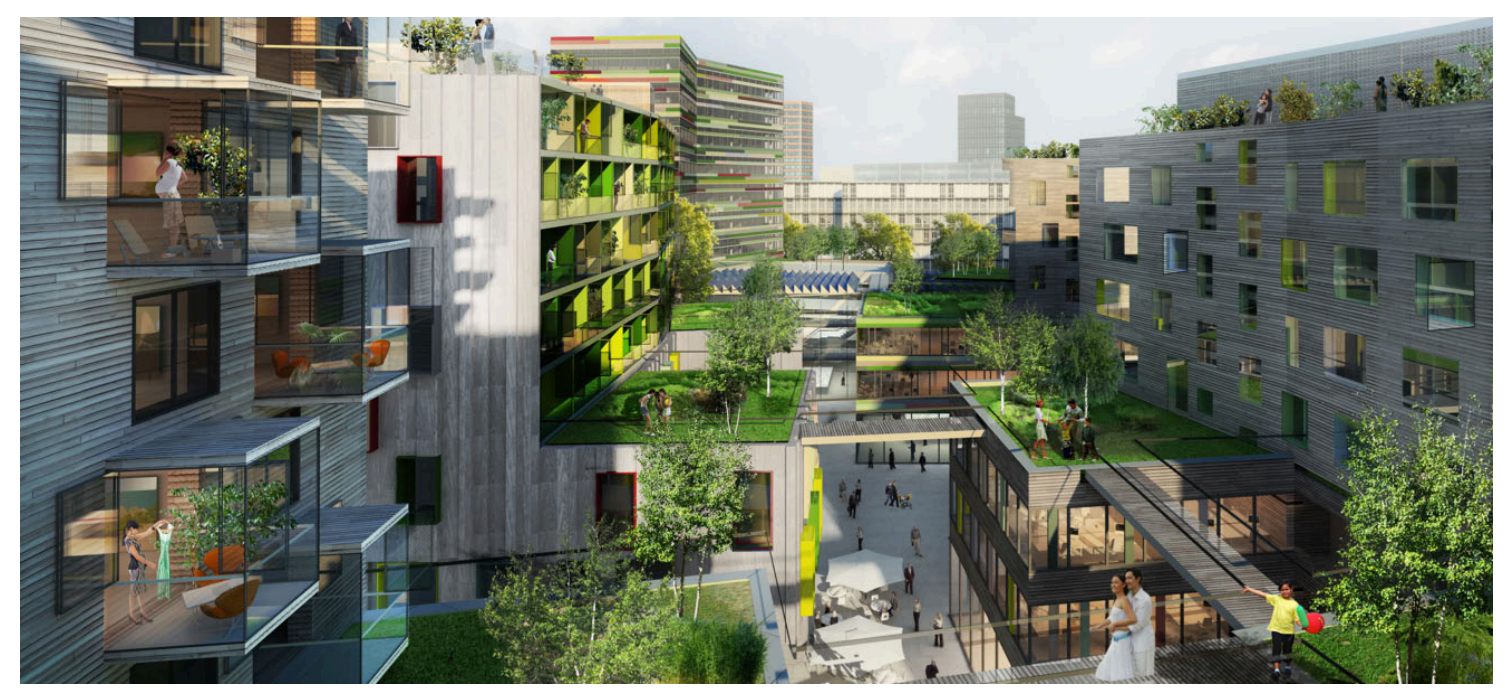

Figura 113: Perspectiva do conjunto habitacional proposto para o Low2No (Fonte: ARUP; SAUERBRUCH HUTTON; EXPERIENTIA, 2009, p.53)

O Low $2 \mathrm{No}^{225}$ foi um concurso realizado por uma agência de inovação finlandesa, junto a incorporadores e outros parceiros governamentais, cujo objetivo era criar um conjunto habitacional, em um vazio urbano da cidade de Helsinki. Os projetos submetidos deveriam ter como objetivo a exploração de modos de construção e vida sustentáveis, de forma que as soluções apresentadas pudessem servir como modelo a ser reproduzido em outras cidades e contextos. O desafio era repensar o crescimento

\footnotetext{
224 Ambos os projetos foram produtos de concursos cujas propostas de todas as equipes estão disponíveis online. No caso do Low2No, os documentos encontram-se no site <http://www.low2no.org/pages/outcomes>, acesso em 28 de Jan, 2014; os do Fredericia C+ estão disponíveis em:

<http://www.fredericiac.dk/Planer+og+byggeri/Parallelkonkurrencen/Holdenes+forslag.aspx>, acesso em 28 de Jan. 2014.

225 Mais informações sobre o Low2No disponíveis em <http://www.low2no.org/pages/competition>. Acesso em 02 Jan. 2012.
} 
das cidades e sua transformação, a partir de propostas que minimizassem o impacto ambiental, tanto da construção e do edifício quanto dos hábitos e modos de vida das pessoas que iriam, posteriormente, ocupar esse espaço.

Nesse projeto, o escritório de design de interação contribuiu com o desenvolvimento de estratégias sustentáveis para a área. Projetou-se um cenário humano de evolução, a partir de uma extensa pesquisa em modelos de serviços, tecnologias, espaços e soluções, já existentes em outros locais do mundo. Além disso, promoveu-se uma série de workshops participativos com possíveis moradores da nova área. Em síntese, aplicaram-se as ferramentas que geralmente se utilizam para o desenvolvimento de interfaces, no projeto de um espaço para a cidade. Uma vez que venceram o concurso, a parceria continuou, conforme comentários do fundador e diretor criativo do escritório de design de interação:

[...] Nós estamos trabalhando em diversos desses aspectos que lidam com modos de vida sustentáveis, modos de vida engajados, usando idéias que circundam a mudança comportamental, uso misto, design participativo e soluções de gerenciamento de demanda para ampliar a perspectiva do que os arquitetos e planejadores normalmente fazem. E novamente, trazemos para o processo um amplo conjunto de habilidades etnográficas para realmente entender as partes interessadas e dar suporte à elas no desenvolvimento 226 (ZOELS, 2011, n.p.).

FredericiaC+ foi um concurso destinado a escolher propostas para ocupar uma área muito maior, que demandava um planejamento complexo a ser implementado, gradualmente, em um período de 25 anos. Trata-se da reurbanização de uma grande gleba urbana de Fredericia, uma cidade dinamarquesa de 40 mil habitantes (Figura114).

A área a ser implantado o projeto, dava lugar a um antigo porto e a uma fábrica de fertilizantes, o que tornou o solo altamente contaminado, impedindo sua ocupação. Apesar do time de engenheiros, arquitetos e designers de interação não terem vencido esse concurso, as estratégias de aplicação dos modos de trabalho do design de interação em um projeto de arquitetura, contribuem diretamente para este trabalho.

\footnotetext{
226 Do original em inglês: [...] We're working on several of these aspects dealing with sustainable lifestyles, engaging lifestyles, using ideas around behavioral change, mixed use, participatory design and demand management solution to widen the outlook of what architects and planners and engineers normally do. And again, bringing in strong ethnographic skill sets to really understand stakeholders and support them in the development (ZOELS, 2011, p.2).
} 


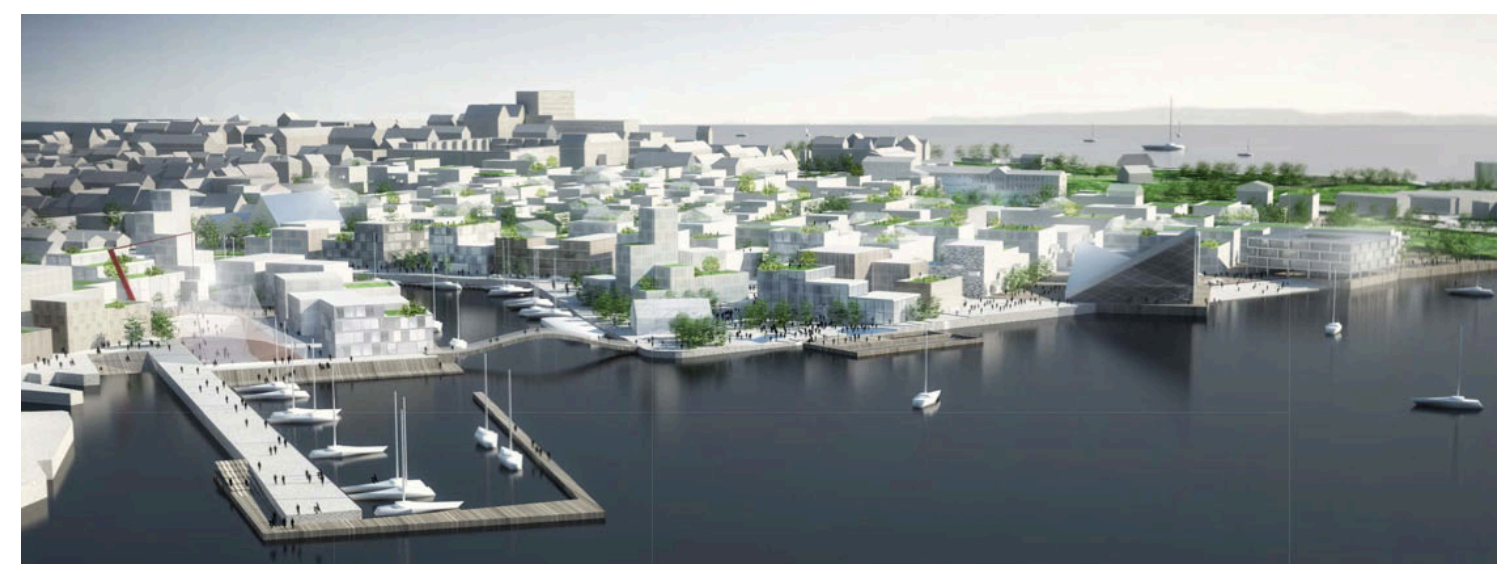

Figura 114: Proposta de desenvolvimento urbano para Fredericia, Dinamarca (Fonte: <http://www.fredericia.dk> Acesso em: 10 Fev. 2014)

Nestas propostas de desenvolvimento urbano, com grande foco em questões sustentáveis, o escritório de design de interação foi responsável pela proposta de diferentes estratégias de comunicação e serviços, a serem implantados, gradativamente, na área. A intenção era elaborar sugestões de práticas, tendo em vista tornar essas áreas, desde o início, vivas, atrativas e capazes de fornecer suporte para uma mudança comportamental, em relação aos modos de vida, consumo e à sustentabilidade.

Em ambos os projetos, em relação à forma como as responsabilidades foram divididas na equipe, os engenheiros se responsabilizaram por questões infraestruturais e estruturais, a arquitetura pelas questões espaciais, e o design de interação pela proposta de cenários do dia a dia, que ilustrassem as interações entre as pessoas que iriam habitar e interagir com e por meio do espaço e da infraestrutura implementada. Assim Zoels (2011, n.p.) define a participação de seu escritório no processo:

Aplicamos coisas tais como métodos de pesquisa etnográfica, observações do que as pessoas fazem, do que elas precisam, o que são os espaços, quais são as interações e, em seguida, realmente trazendo elas para o processo de design. Isso, como temos visto, tem realmente aberto muitas portas. As pessoas tem nos percebido, que estamos ouvindo, que estamos usando esses inputs do processo de escuta ou observação no design para projetar espaços mais viáveis, apropriados e atrativos. ${ }^{227}$

Para ilustrar esse discurso, é importante descrever alguns produtos, desenvolvidos para os projetos e que foram incorporados em seu material de apresentação, junto

227 Do original em inglês: We use things as like ethnographic research methods, observing what people do, what they need, what are the spaces, what are the interactions and then actually bringing this into the design process. This we have seen, has really opened a lot of doors. People have perceived us, that we're listening, that we are using these insights from the listening processes or observation processes in the design and therefore to design more feasible, appropriate and engaging spaces (ZOELS, 2010, p.3). 
com plantas, desenhos, memorial descritivo e estratégias de implementação da infraestrutura. No geral, a contribuição do design de interação se deu, por exemplo, na proposição de personas, dia na vida (day in a life) e cenários (Figura 115-116), bem como na sistematização de 50 estratégias (ferramentas e serviços) que poderiam servir de apoio e estímulo para o desenvolvimento de hábitos de vida mais sustentáveis pelos moradores. Essa aproximação com o projeto foi assim descrita:

Para criar os conceitos para mudança de comportamento, começamos através da elaboração de perfis hipotéticos das pessoas que poderiam viver na área e do tipo de estilo de vida que elas poderiam usufruir [personas]. Olhando para o movimento do dia-a-dia dessas pessoas, começamos a gerar ideias em torno do tipo de necessidades e atitudes que poderiam ter, do tipo de serviços e produtos que poderiam querer, e como seus comportamentos deveriam e poderiam mudar para se tornarem mais sustentáveis 228 (ARUP; SAUERBRUCH HUTTON; EXPERIENTIA, 2009, p.79).
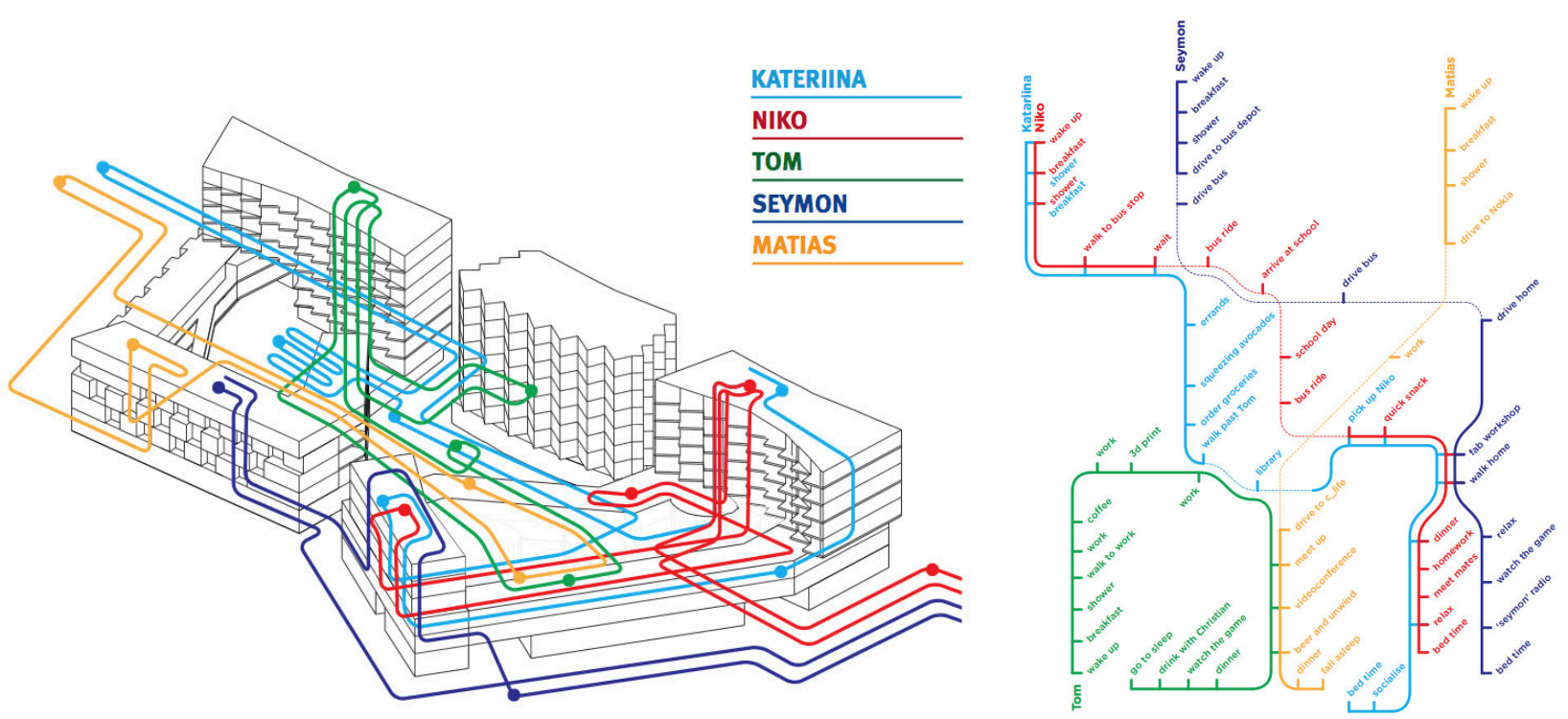

Fig. 115-116: Dinâmica e circulação das personas ao londo de um dia, no novo edifício do projeto Low2No. Essa estratégia auxilia na visualização da integração dos serviços propostos, no cotidiano das pessoas (Fonte: ARUP; SAUERBRUCH HUTTON; EXPERIENTIA, 2010a, p.26)

As ferramentas e serviços, elencados pelo escritório de design de interação, foram, segundo Aalen (2011) - arquiteto, gerente de projetos do escritório de arquitetura do projeto Low2No - importantes para delimitar o conteúdo e escopo do espaço. Em um primeiro momento, a partir da observação e pesquisa foi possível elaborar a descrição de perfis hipotéticos, de possíveis serviços a serem implementados na área, bem como

\footnotetext{
228 Do original em inglês: In order to create our behavior change concepts, we started by drafting hypothetical profiles of the people who might live in the area and the kind of lifestyles they might live. Looking at the day-today movement of these people, we started to generate ideas around the type of needs and attitudes they might have, the type of services and products they might want, and how their behaviors should and could change for them to become more sustainable (ARUP; SAUERBRUCH HUTTON; EXPERIENTIA, 2010, p.79).
} 
de recursos informacionais para estimular o senso de comunidade e de sustentabilidade dos moradores. Essa contribuição se fez fundamental, especificamente no caso do Low2No, no qual as intenções e programa do concurso eram bastante abstratas, já que se tratava, além da construção de edifícios, também da exploração de idéias alternativas relacionadas à sustentabilidade.

Uma vez que a equipe composta pelos três escritórios fora contemplada no concurso e o projeto oficialmente iniciado, uma estratégia de design centrada nas pessoas, multidisciplinar e colaborativa, foi colocada em prática. Dentre outras ações, pesquisas em campo com pessoas reais (habitantes da cidade) em suas casas, cujo perfil se assemelha ao almejado, forneceram informações sobre hábitos de consumo e entendimentos sobre sustentabilidade (Figura 117). As percepções, geradas por essas atividades, desencadearam a elaboração de diversos conceitos, utilizados para o desenvolvimento de sistemas inteligentes, para a proposição de uso misto para a área e para a proposição de outros processos para a equipe geral do projeto. (ARUP; SAUERBRUCH HUTTON; EXPERIENTIA, 2010b).

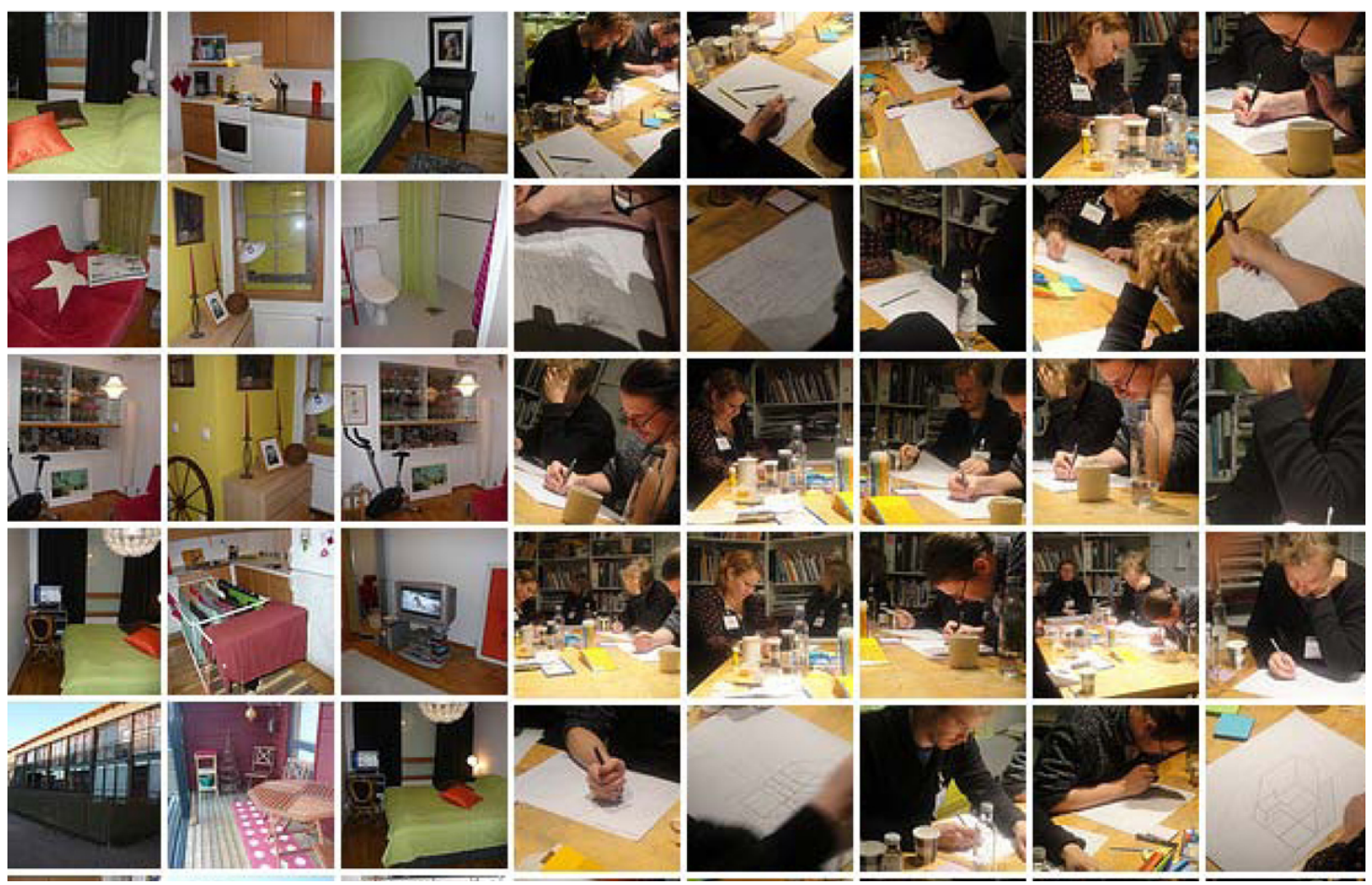

Fig. 117: Workshop Futuros Residentes (Fonte: <http://www.low2no.org/blog/51-52-week-in-review> Acesso em: 30/01/2014)

Os diversos sistemas inteligentes propostos, enquadram-se no que se denomina de informática urbana (urban informatics) e resultam de uma aproximação holística às questões colocadas pelo projeto (ARUP; SAUERBRUCH HUTTON; EXPERIENTIA, 2010b). Nessa perspectiva, a descrição do projeto inclui não apenas a forma como edifícios são projetados, construídos e gerenciados, mas também as camadas 
informacionais que influenciam em como os espaços são utilizados e evoluem. Para ilustrar as possibilidades tecnológicas e sua inserção no cotidiano dos moradores e frequentadores do edifício, diversos cenários de utilização desses recursos foram elaborados, a partir das personas criadas, bem como sua integração nos diferentes espaços (Figura 118-119).
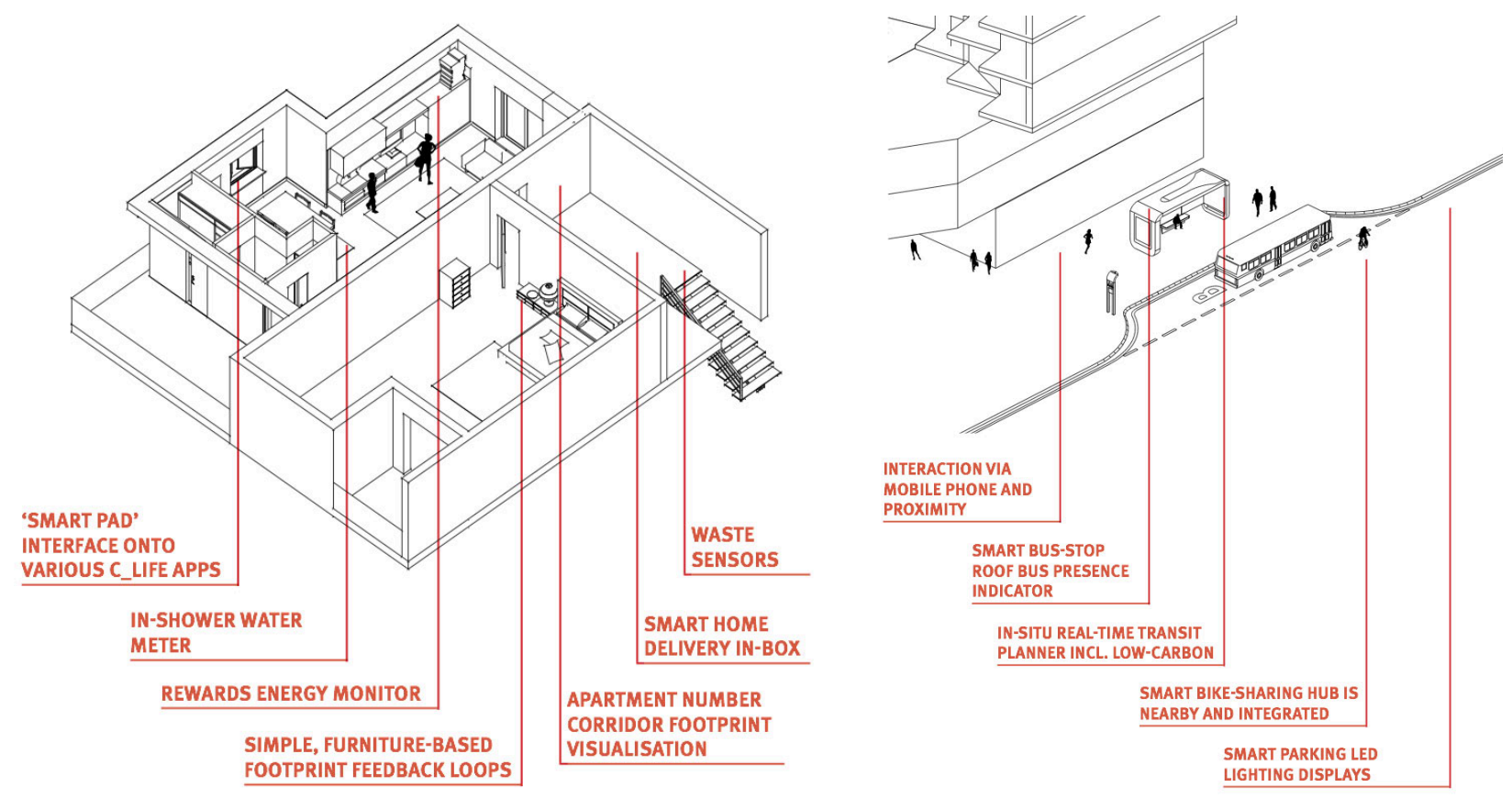

Figura 118-119: Dispersão dos diversos sistemas informacionais nos espaços. Sua incorporação pelas pessoas é ilustrada nas histórias das personas (Fonte: ARUP; SAUERBRUCH HUTTON; EXPERIENTIA, 2010a, p.36)

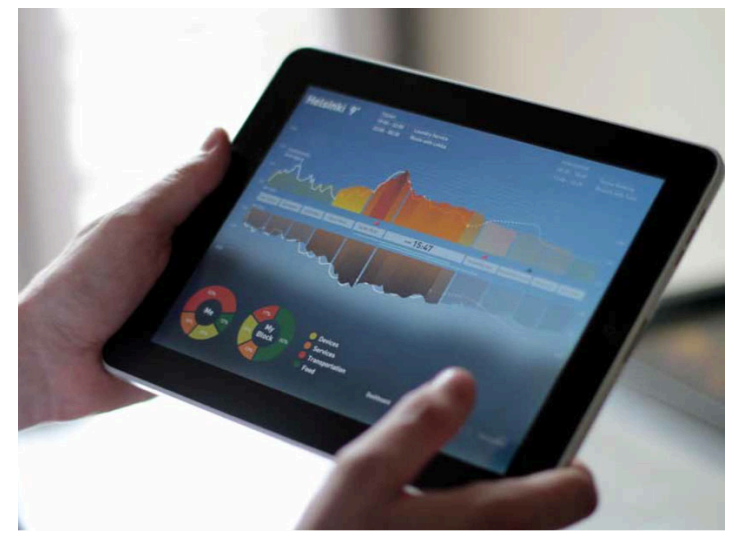

Figura 120: Interface para dispositivo móvel do home assistant (Fonte: ARUP; SAUERBRUCH HUTTON; EXPERIENTIA, 2010b, p.32)
Em decorrência da importância conferida pelo projeto aos comportamentos sustentáveis, uma especial atenção foi dada à elaboração de uma plataforma online que funcionasse como um assistente doméstico (home assistant) (Figura 120). Suas funcionalidades incluem visualizações e comparações do consumo energético, acompanhadas de sugestões comportamentais para reduzir o gasto. A consciência do consumo energético, nesse caso, além de ser pensado em nível individual, é, também, estimulado coletivamente, de forma a nutrir o senso de comunidade e consciência dos moradores.

No projeto FredericiaCt, apesar da utilização de modos de trabalho semelhantes, as principais questões trabalhadas foram outras. O objetivo do Low2No era desenvolver 
estratégias para implementação de modos de vida sustentáveis, que pudessem ser posteriormente reproduzidas. Já, em FredericiaC+, o desafio era propror um plano de ação para os próximos 25 anos, para uma área que, até então, tinha sido evitada pela população, dado o alto grau de contaminação do seu solo. Ao mesmo tempo, sua localização é privilegiada por separar a cidade do mar. Zoels (2011, n.p.) assim comenta sobre a especificidade desse projeto:

[...]Nos vemos contribuindo especificamente imaginando ou propondo uma série de processos participativos que podem ajudar essa área diversificada a crescer. Crescer em múltiplas etapas. Assim, achamos que os processos participativos, que descrevemos e sugerimos para diferentes etapas, podem realmente ajudar o cliente a tomar decisões mais apropriadas. Ajudamos, por meio do desenvolvimento de uma série de idéias para uma Fredericia sustentável, a modelar conteúdos alternativos para a área dos edifícios e pensar a partir de uma perspectiva social, econômica e sustentável, o que faz uma área ser rica, o que faz ela ser atraente, o que ajuda as pessoas a se mudarem para ela, e como isso lida com alguns problemas que existem atualmente naquela comunidade. ${ }^{229}$

As idéias para uma Fredericia sustentável foram elaboradas, inicialmente, em resposta a uma primeira etapa do projeto, cujo objetivo era apresentar propostas de usos temporários para a área. A intenção era ocupar o espaço de imediato, implementar soluções ainda durante a competição até as obras serem iniciadas. Para isso, foram elencadas atividades que contribuíssem para o estímulo da apropriação daquela área, tanto afetiva quanto funcionalmente, pelos atuais moradores da cidade. O conteúdo foi organizado na forma de cartas, entregues às partes interessadas, durante a apresentação.

As cartas consistiam em quatro categorias de atividades: comida e hospitalidade, laboratório de memórias, sustentabilidade e cultura. Cada tópico era explorado com aproximadamente 12 idéias, cada uma em uma carta, contendo imagem ilustrativa, título e curta descrição (Figura 121-128). Com as cartas na mão, as pessoas poderiam priorizar aquelas sugestões que eram mais ou menos atrativas bem como que

\footnotetext{
229 Do original em inglês: [...] we see ourselves particularly contributing to imagining or proposing a series of participatory processes which can help these diverse area to grow. Grow over multiple stages. So, we think the participatory processes, which we outlined and suggested in different stages, can actually help the client make smarter decisions. We helped, through a series of idea developments for a sustainable Fredericia, to model alternative content for these building area and to think from a social, economical, and sustainable perspective, of what makes an area a rich area, of what makes it engaging, what helps people to move over that. And how does it address some of the existing problems in the community right now [...]. So, these are identity issues, these are social issues and how we addressed, we didn't look automatically what does it mean purely for the build space (ZOELS, 2011, n.p.).
} 
julgavam realizáveis ou sem qualquer sentido. Como comenta Zoels (2011, n.p.), "[...] ]essencialmente estamos fazendo um mapeamento de oportunidades e permitindo que as pessoas façam algumas seleções por elas mesmas. No lugar de mostrar apenas uma ou três idéias, mostramos um conjunto de $50 .{ }^{230}$

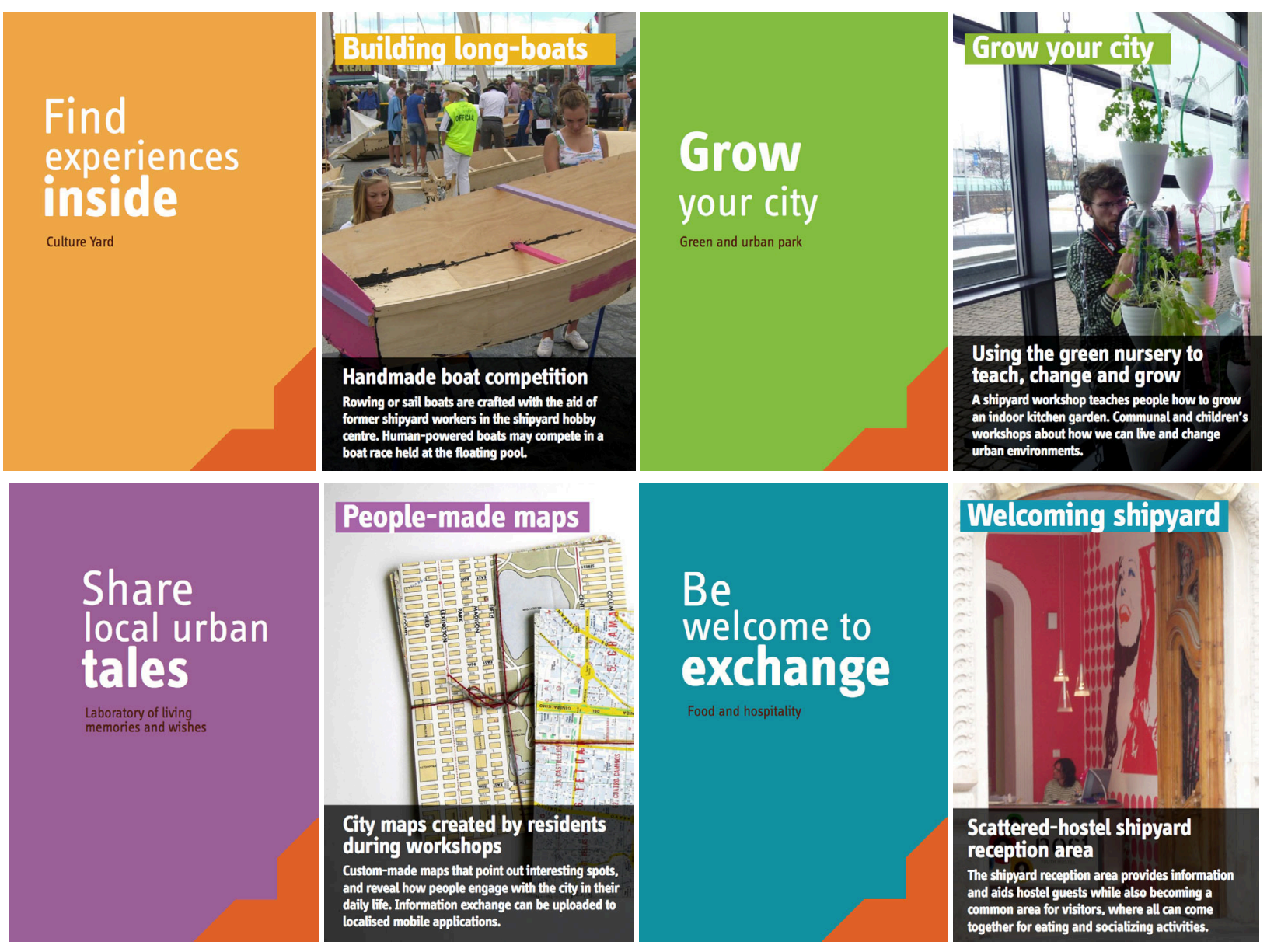

Figura 121-128: Categorias das atividades temporárias e exemplos correspondentes (Fonte: Experientia)

Esse mesmo material foi, também, apropriado pela equipe do escritório de design de interação, como insumo para discussões etapas que se seguiram, do projeto (Figura 129). Do temporário ao permanente, a principal contribuição dessa perspectiva comportamental ao projeto, era imaginar e ilustrar a introdução de estratégias iniciais e como essas se desenvolveriam ao longo do tempo. A intenção era fomentar a mudança de opinião das pessoas sobre aquela área, até então, degradada, engajá-las em processos social e economicamente sustentáveis bem como construir concomitantemente o espaço físico e seu conteúdo.

230 Do original em inglês: [...] essentially, we are doing a opportunity mapping and enabling people to make some selection processes in itself. Instead of just showing one or three ideas, showing a range out of fifty (ZOELS, 2011, n.p.). 
No caso de Fredericia, o desenvolvimento de personas e cenários deu-se a partir de objetivos distintos daqueles que guiaram a criação de personas para o projeto Low2No. No caso finlandês, a intenção era imaginar e ilustrar as pessoas, no contexto do espaço construído, interagindo entre si, com as diversas plataformas e infraestrutura propostas. No FredericiaC+, dada a grande escala do projeto e seu longo tempo de duração, essas estratégias foram utilizadas para ilustrar a apropriação da área com o passar dos anos. Assim, foram explorados, dentre outros, perfis de: pessoas que já moram na cidade e que no futuro se mudariam para a nova área; pessoas que não moram na área mas passam a utilizá-la para o lazer e trabalho; pessoas atraídas para a cidade em decorrência do projeto; e histórias de famílias se formando e crescendo junto com esse novo espaço (Figura 130).

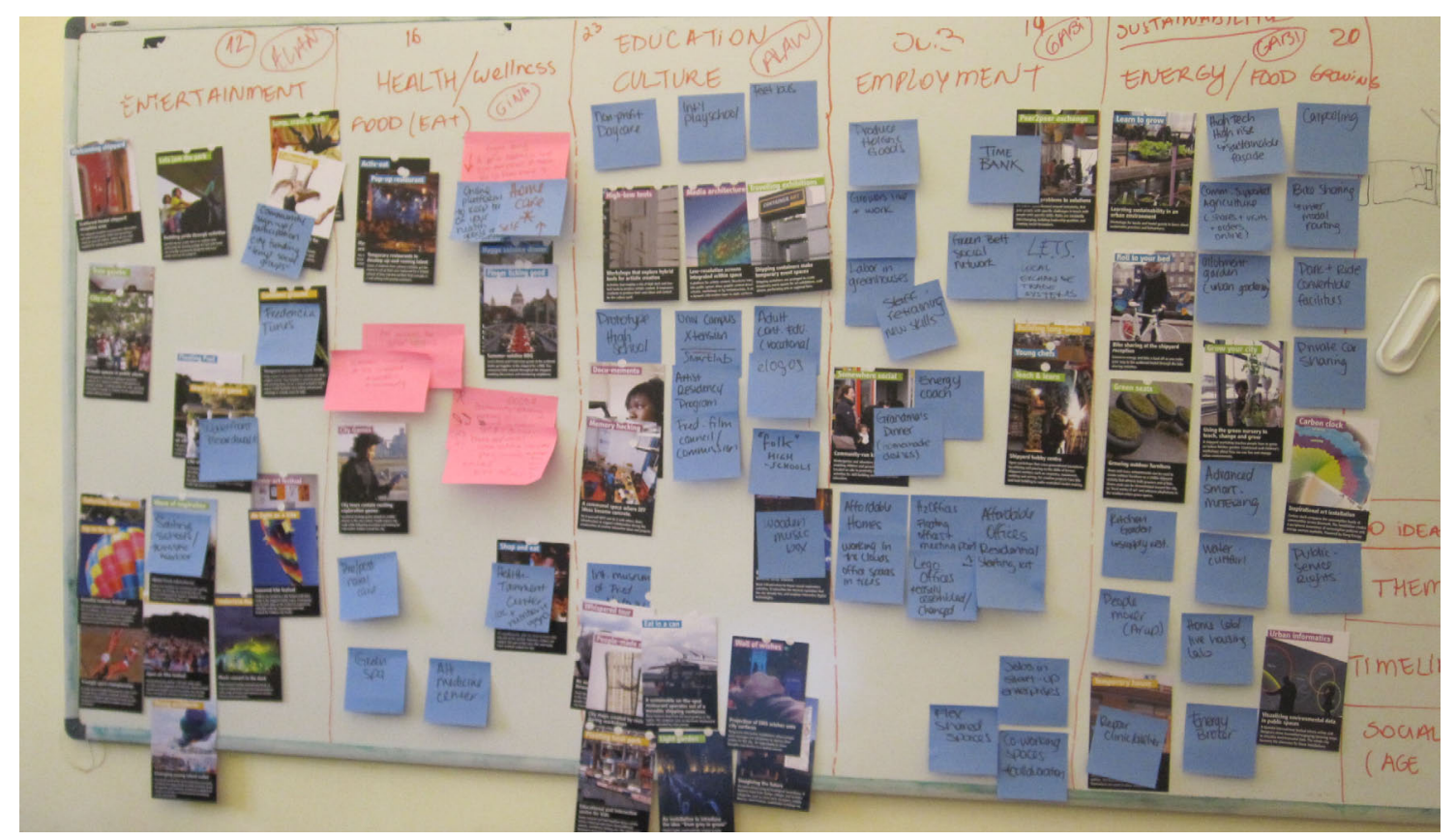

Fig. 129: Painel montado no escritório, com as cartas das atividades temporárias, para discussão sobre a evolução das atividades temporárias para permanentes (Fonte: Gabriela Carneiro)

De modo geral, a perspectiva do design de interação ajudou na visualização e entendimento do espaço proposto, a partir do ponto de vista das possíveis pessoas que poderiam vir a usufruir dessas propostas. No início, personas e cenários são criados, a partir de pesquisa e observação, mas, uma vez que os projetos são aprovados, workshops participativos são incorporados no processo, com a presença de diversos grupos interessados, para o aprimoramento de idéias. Aalen (2011, n.p.) assim resume a contribuição do design de interação para a execução do Low2No:

Quando o projeto confrontou a realização, essas cinqüenta idéias tiveram que encontrar seu lugar e forma. Agora não existem mais 50 mas talvez 10 ou algumas foram fundidas em uma, e os designers de interação descobriram uma boa maneira de 
encontrar a tradução dessas idéias iniciais para a realidade. Eles também ajudaram com o gerenciamento disso. Eles ajudaram a encontrar partes interessadas para o programa de varejo, eles ajudaram a definir o programa para as habitações baseados nos workshops de design participativo, eles ajudaram a olhar para a maneira que o transporte poderia afetar o edifício. 231

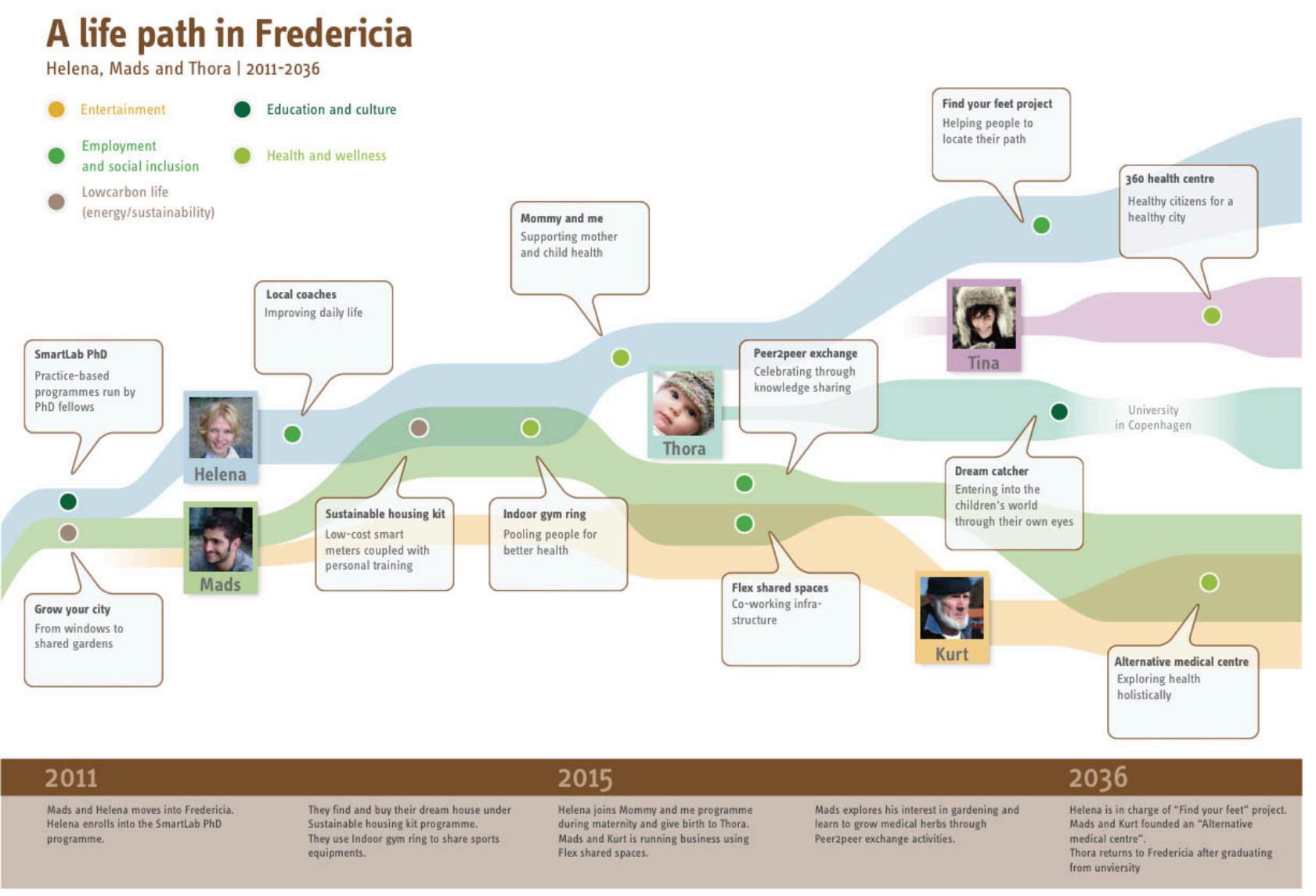

Figura 130: Integração das diferentes personas, com a implentação dos diferentes espaços, ao longo dos 25 anos (Fonte: $<$ http://www.fredericia.dk> Acesso em: 10 Fev. 2014)

No entanto, por mais que as descrições, aqui colocadas, indiquem caminhos interessantes para o diálogo entre essas duas áreas, existem ainda diversas questões problemáticas que emergiram ao longo dos processos, que devem ser encaradas como oportunidades. Pelo que foi observado e vivenciado, uma das principais questões é a tradução dos produtos de uma área em inputs para o projeto da outra. Nesse sentido, existe, ainda, a necessidade de um estudo mais aprofundado de ambos os processos para a criação de estratégias mais compactas e sistematizadas de troca.

\footnotetext{
231 Do original em inglês: As the project faced realization this fifty ideas have to find its place and shape. Now there are no longer fifty but maybe ten or some of them have merged into one. And the interaciton designers has quite successfully found the good way to find the translation of those initial ideas into reality. They have also helped with the management of part of that. They have helped finding the stakeholders of the retail program they have helped defining the program for the housing based on their participatory design workshop, they have helped looking at the way that transport could affect the building (AALEN, 2011, n.p.).
} 
Assim sendo, acredita-se que os parâmetros propostos por essa tese, podem ser entendidos como um passo nessa direção. Ao elaborar conceitos a serem tratados durante o projeto da arquitetura interativa, são trazidos para a arquitetura diversos termos e modos de trabalho comuns ao design de interação. Ao mesmo tempo, a explicação dos parâmetros contribui para o caminho inverso, inclui nos termos e estratégias, aspectos relevantes para que o design de interação compreenda algumas especificidades da arquitetura e possa, assim, elaborar meios mais específicos de colaboração.

\subsection{Parâmetros conceituais para o design da arquitetura interativa}

Os parâmetros para o design da arquitetura interativa, aqui descritos, derivam do questionamento a respeito de como conceber e projetar objetos e espaços interativos. $\mathrm{Na}$ pesquisa de mestrado sobre objetos interativos, conforme Carneiro (2008), o principal questionamento foi a importância de encarar os sistemas digitais da mesma maneira que são tratadas as formas e os materiais. Trata-se de sua incorporação ao design do objeto como um todo, como um dos recursos a serem utilizados para transmitir significados, ideias e visões de mundo.

Para viabilizar essa perspectiva foi importante, em um primeiro momento, o entendimento de possibilidades técnicas de programação de microcontroladores e desenvolvimento de circuitos integrados. Acreditava-se que, para ser possível esse tipo de design de objetos e espaços, era imprescindível a apropriação prática dessa linguagem e de suas possibilidades. Porém, nem sempre todas as pessoas envolvidas no design, deste tipo de produto, são fluentes em programação e em temas técnicos específicos da tecnologia digital. Da mesma maneira, nem sempre há tempo hábil em um processo de design para a explicação de todas essas questões.

A necessidade de dialogar sobre questões técnicas, em equipes mistas e heterogêneas - com pessoas leigas e especialistas - motivou o desenvolvimento das i/o Cards (CARNEIRO et al, 2012). Como já mencionado, trata-se de um conjunto de cartas para serem utilizadas como suporte para, rapidamente, explicar o conteúdo técnico e inspirar pessoas não especialistas a discutirem propostas de objetos e espaços interativos. As cartas foram utilizadas em diversas dinâmicas, e foram sempre muito bem recebida pelos participantes, enquanto ferramenta para estimular o dialogo e a criatividade, como ilustra a Figura 131-134.

As cartas são divididas em dois grupos: estruturais e conceituais. Foram as cartas estruturais (Figura 105, pg. 188) que motivaram o desenvolvimento das ilo Cards, de 
forma que foram as primeiras a serem criadas. Derivam da necessidade de apresentar os fundamentos da tecnologia digital (input-processamento-output) nas discussões, identificada no trabalho de mestrado (CARNEIRO, 2008). Nas primeiras vezes, nas quais as cartas foram empregadas, tratavam-se de workshops cujo objetivo era introduzir questões técnicas para designers e direcioná-los durante o design de objetos interativos. Dessa maneira, para complementar, eram mostrados os componentes reais correspondentes àqueles ilustrados pelas cartas.
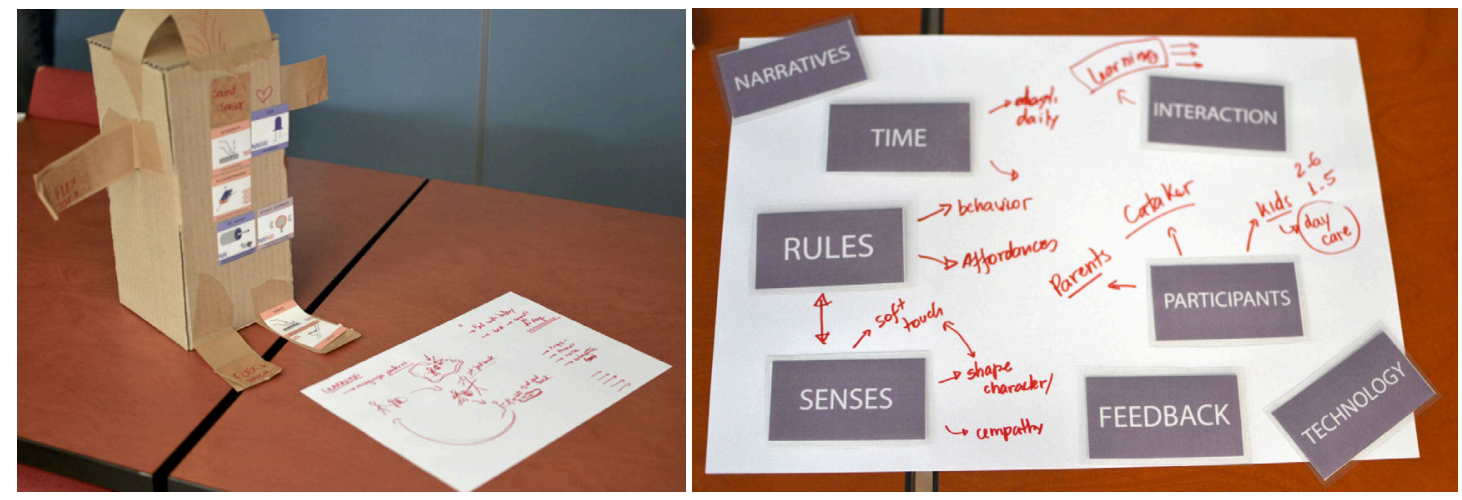

Figura 131-132: i|o Cards sendo utilizadas em workshop criativo (Fonte: Gabriela Carneiro)

Figura 133-134: i|o Cards utilizadas em conjunto com storyboard tetral, para ilustração da estrutura do sistema e do conceito do objeto (Fonte: Gabriela Carneiro)
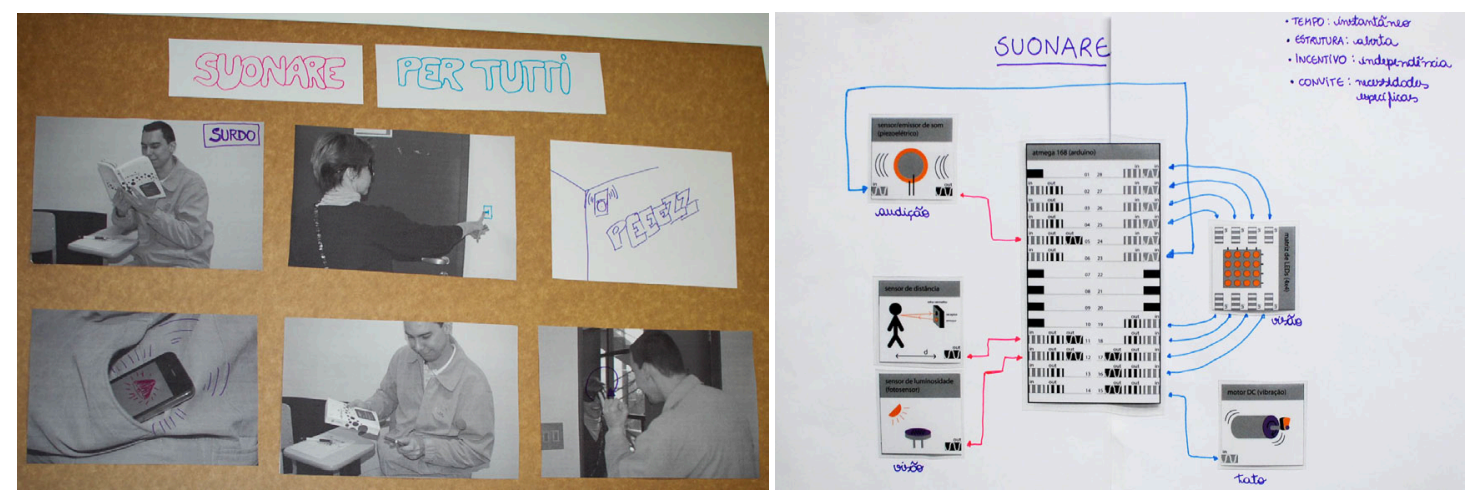

As cartas conceituais (Figura 106, pg. 189) foram inseridas no conjunto, como um material complementar, para auxiliar no processo de design. A primeira versão dos conceitos foi uma adaptação parcial da metodologia, proposta por Mongiat e Snook (2007, p.5), que visa promover maior envolvimento das pessoas em projetos que demandem participação de diferentes grupos de partes interessadas (stakeholders). Parte dessa metodologia, consiste na proposição de "[...] componentes fundamentais da interação". Esse componentes, são apresentados, na forma de uma lista (checklist) de questões necessárias para planejar um ambiente para troca e participação, em um processo de design ou em uma obra de arte interativa. 
Aos poucos, a partir das avaliações realizadas após os workshops com as i|o Cards, ficou clara a relevância e oportunidade que as cartas conceituais representam. Depois de diversas experimentações, entende-se que questões conceituais e subjetivas são de extrema importância para a criação dos objetos e espaços interativos e as questões técnicas, antes encaradas como centrais, tornaram-se complementares. Motivações, intenções e visões de mundo são anteriores a como implementar um sistema e qual tecnologia aplicar.

Os parâmetros conceituais, propostos por este trabalho, derivam desse caminho e do aprofundamento e da adaptação do conteúdo das i|o Cards. O termo parâmetro faz referência ao design paramétrico (Figura 135), processo de design desenvolvido a partir de rotinas que possuem, como base, parâmetros pré-determinados, normalmente utilizados por softwares de modelagem para a geração de formas. Nesse caso, a atribuição de diferentes valores aos parâmetros gera alternativas de soluções, mantendo nelas as mesmas características (CELANI, 2003).

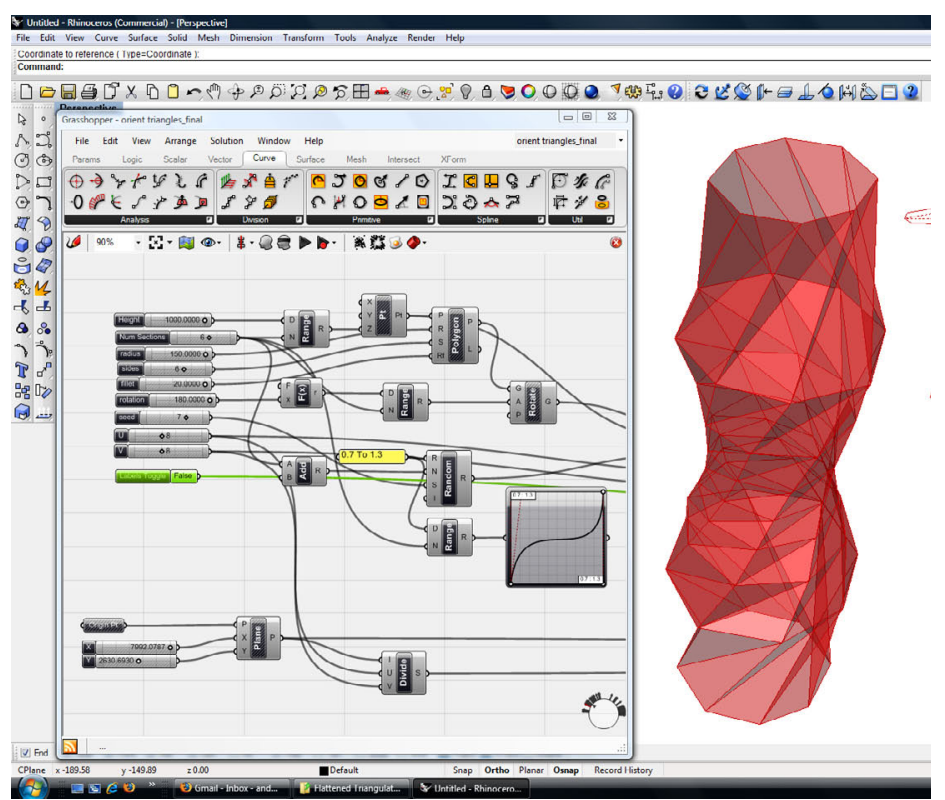

Figura 145: Exemplo de interface de software paramétrico. À esquerda os parâmetros e suas interrelações e à direita a forma resultante. A manipulação dos diferentes parâmetros, bem como a alteração de como se relacionam, geram diferentes soluções formais (Fonte: <http://mlab.cca.edu/wpcontent/uploads/2009/08/toronto-workshop_screen13.jpg> Acesso em $11 \mathrm{fev}$ 2014)

Por outro lado, os parâmetros conceituais diferem-se daqueles utilizados pelo design paramétrico pois uma de suas característica é não serem quantificáveis. Em sua essência, são princípios elencados para fornecer elementos conceituais passíveis de serem manipulados durante o design da arquitetura interativa. Nesse sentido, não se trata de uma prescrição de conceitos ou critérios a serem seguidos exatamente como são propostos, mas sim, da sugestão de questões conceituais a serem debatidas pelos participantes do processo. Estas podem aparecer com maior ou menor relevância, dependendo do conceito explorado e dos recursos disponíveis.

A partir dessa perspectiva, os parâmetros conceituais, aqui propostos, podem ser utilizados para diversos fins. Em primeiro lugar, podem ser adotados como um conjunto de requisitos a serem ponderados em diversas etapas do processo de design, com o intuito de estimular conversas e oferecer outras perspectivas das propostas. Além disso, a discussão desses conceitos (e de outros que forem relevantes) pode 
levar à especificação de um vocabulário comum entre grupos de diferentes procedências e especializações, envolvidos no processo de design. Por fim, esses parâmetros podem ser, também, utilizados para auxiliar o entendimento e a análise das especificidades deste tipo de arquitetura.

Vale ressaltar que, a necessidade de manipulação de variáveis conceituais, deriva do entendimento da arquitetura interativa enquanto entidade dinâmica que troca informações com seu contexto. A partir desse pressuposto, são propostos nove parâmetros, que podem ser utilizados, como pontos de partida para a criação desse tipo de espaço. Essa abordagem é resultado direto da pesquisa empreendia para essa tese, e é proposta com a intenção de expandir as possibilidades projetuais de arquitetos e designers. Acredita-se que, com a incorporação desses parâmetros, seja possível a esses profissionais, mesmo sem conhecimento prévio de questões técnicas dos sistemas digitais, atuarem no design da arquitetura interativa.

\subsubsection{Participantes}

- Quais são as partes envolvidas na interação?

- De que maneira esses participantes atuam - antes, durante e depois - no processo de design?

- Como cada participante se relaciona com a arquitetura interativa proposta?

O termo participantes é utilizado para incluir, na discussão da arquitetura interativa, partes outras além daqueles à quem o espaço se destina. A intenção é ampliar a perspectiva do usuário ou do interator, incluindo nela outros elementos que, de alguma maneira, podem vir a influenciar o comportamento do espaço. Essa abordagem inclui, por exemplo, questões ambientais, quando dados específicos são extraídos desses aspectos e influenciam, de alguma maneira, o interação como um todo. Assim, o clima e sua variação pode ser encarado, dependendo da relevância que essa questão exerce no sistema, como um dos participantes da interação.

Falar sobre participantes pode, em um primeiro momento, parecer óbvio. Porém, acredita-se que este é um aspecto de extrema relevância para o design da arquitetura interativa, assim, não deve ser encarado como uma questão simplesmente dada pelo escopo do projeto. O design desse tipo de espaço deve incluir os diferentes participantes a partir de suas especificidades - histórias, interesses, comportamentos e relevância - e da possibilidade de contribuição para o projeto. Desse modo, a sistematização desses aspectos auxilia, significativamente, a elaboração e elucidação da trama de relações da qual o espaço fará parte. 
Nesse sentido, Mongiat e Kelsey (2007) elencam quatro categorias de participantes, que ilustram a abordagem proposta por este trabalho, a saber: os agentes executores (makers), os clientes, a audiência e o ambiente. Os agentes executores são as pessoas envolvidas no processo, com a responsabilidade de realizá-lo, ou seja, de efetivamente fazê-lo acontecer. Podem ser tanto pessoas com habilidades específicas, quanto aquelas com funções administrativas ou habilidades comunicativas. Os clientes compreendem as pessoas ou grupo interessados em passar alguma mensagem específica, por meio do projeto em questão. São os preocupados em fazer a coisa acontecer, seja lá qual ela for, pois possuem interesses específicos sobre ela. A audiência é composta pelas pessoas para quem o projeto será concebido, sejam elas usuários, visitantes, espectadores, interatores ou, até mesmo, passantes e transeuntes. O ambiente englobam o espaço físico, ambiente natural, espaço digital, bem como outras dimensões, tal como a internet e a conectividade móvel. Isto é, qualquer entidade, passível de ser descrita, que desempenhe papéis específicos no desenrolar da interação.

A importância de trazer essas questões à tona, como um parâmetro de projeto, deriva do fato de não serem evidentes e nem mesmo estanques. Dependendo do contexto, a audiência pode, igualmente, ser o cliente, ou um agente executor. Mapear os participantes e seus contextos logo no início do projeto ajuda, assim, a apoiar as relações que podem ser criadas no desenrolar do processo. Assim, a especificidade de cada parte pode vir a influenciar a dinâmica global da interação pretendida. Quem é, bem como o que caracteriza cada participante são conceitos maleáveis, que atuam como variáveis, podendo assim, assumir diferentes constituições nos diversos momentos do projeto. Por este motivo devem ser constantemente explicitados e reelaborados.

Uma análise da estrutura de criação e de interação do Ambiente Interativo D3, ajuda a ilustrar essa questão. No início, estava clara a existência de executores (arquitetos) e clientes - neste caso, também audiência - e o ambiente era, simplesmente, o resultado pretendido. Com a aceitação da proposta interativa para o espaço, essas categorias adquiriram certa maleabilidade. O ambiente deixou de ser apenas um resultado estanque do processo e passou a atuar como entidade dinâmica. Dados de sua utilização passaram a ser importantes para o contexto interativo e, assim, passaram a ser incorporados como participantes da interação. 
Os clientes e audiência, ao longo do processo, foram capacitados para se tornarem, também, executores (makers), já que a estrutura da interação previa sua incorporação criativa pelos habitantes do espaço. Falar sobre participantes significa, assim, construir uma estrutura conceitual, que permita a determinação de diferentes níveis de participação das partes, ao longo do processo.

No caso do Ambiente Interativo D3, por exemplo, a inclusão dos clientes e audiência, no processo, foi essencial para criar um senso de compromisso e pertencimento destes, com a dinâmica proposta para o espaço. Nesse projeto como um todo, existe uma linha tênue, que diferencia o processo de design do resultado final. Isso acontece, pois, partia-se do princípio que o espaço só estaria pronto, uma vez que tivesse sido, de alguma maneira, apropriado pelos participantes da interação como plataforma para criação de outras dinâmicas interativas.

Isso mostra que, muitas vezes, a participação das partes, em um projeto de arquitetura interativa, não se restringe ao espaço final e construído. Ela pode também compreender as etapas de projeto. Nesse caso, as necessidades e critérios para a interação, definidas para espaço final, foram construídas ao longo de seu processo de design, como resultado das diversas interações que foram estimuladas, entre os participantes.

De modo geral, falar sobre os participantes do projeto, e das especificidades de cada um, ajuda na determinação do contexto maior da interação. Trata-se, assim, de estipular de onde advém as informações que serão utilizadas e processadas, tanto diretamente pelo espaço construído, quando durante as fases de concepção. Mapear as partes que determinam um projeto, e sua influência ao longo do tempo, auxilia também, na visualização de oportunidades de quando e como trocas podem acontecer.

\subsubsection{Tempo}

- O que acontece imediatamente, em segundos, ao longo de horas, dias e anos?

- Como as diferentes escalas temporais são incorporadas pela interação proposta?

Como mencionado anteriormente, uma das principais características do sistema digital é a maleabilidade do mapeamento lógico do que acontece, quando é estimulado. Um interruptor comum, acende uma lâmpada ao ser acionado. Nesse caso, há um circuito elétrico fixo, esperando apenas a passagem de energia para funcionar de maneira já 
determinada. O sistema digital permite que essa relação entre ação e reação adquira características mais elaboradas. Por exemplo, pode-se determinar que, quando o sistema for acionado por três horas, deixe de funcionar pelas próximas cinco, ou mesmo que ele ligue e desligue em horários específicos.

Quando é um sistema digital que está em questão, nem toda ação pressupõe uma imediata reação. Da mesma maneira, a reação não precisa ser sempre a mesma e nem acontecer de forma previsível. Assim, falar sobre o tempo enquanto parâmetro conceitual para a arquitetura interativa, significa incorporar o que essas possibilidades podem vir a agregar à idéia como um todo. Trata-se de discutir o que acontece e quando acontece, bem como o significado disso em um contexto mais amplo.

Respostas imediatas podem capturar o interesse momentâneo das pessoas que interagem com o espaço. Esse recurso pode ser utilizado, por exemplo, como recurso para estimular um envolvimento lúdico da pessoa com a arquitetura. A percepção de que alguma ação desempenhada por ela, possa ter estimulado comportamentos inesperados no espaço, pode estimulá-la a entender a lógica do ocorrido. A pessoa pode, assim, repetir a ação e observar a reação e tentar outras estratégias para ver se algo diferente acontece.

Respostas a médio e longo prazo podem estimular relacionamentos com atributos mais duradouros, das pessoas com a arquitetura interativa. De tal modo que, em cada visita ao espaço, podem perceber que suas características não são mais as mesmas da última vez, e podem ficar curiosas com este fato. No geral, o ponto principal é compreender que, quando e como o sistema reage, são propriedades importantes de serem exploradas.

Diferentes estímulos podem gerar variadas reações. Uma boa estratégia para lidar com essa possibilidade é estabelecer uma hierarquia de reações ao longo do tempo, de acordo com o estímulo recebido. Comportamentos prioritários são sobrepostos aos que se encontram abaixo deles, na escala hierárquica. Como exemplo, pode-se imaginar um espaço que reage à variação anual de temperatura porém, quando uma pessoa entra, responde imediatamente a seus movimentos. Se, em seguida, várias outras pessoas entram, inicia-se um terceiro tipo de resposta, dessa vez levando em consideração o barulho emitido por elas. Na medida em que as pessoas saem, entra em vigor, novamente, o comportamento inicial. 
Da mesma forma, um tempo pode influenciar outros. A utilização de um espaço a longo prazo, pode servir de insumo para a determinação de novos padrões para as reações imediatas. Assim como, o estímulo constante, pode também influenciar nas equações que geram outros tipos de resposta. Variações dessa estratégia, podem adicionar fatores de imprevisibilidade à interação, já que novas respostas e comportamentos são gerados pelo sistema, a partir de como se desenrolam os usos efetivos do espaço.

A sobreposição de interações ao longo do tempo pode ser outro recurso interessante a ser manipulado. Diferentes reações podem ser estimuladas, por exemplo, com muitas ações ao mesmo tempo, poucos estímulos em muito tempo, assim como uma atividade intensa em um longo intervalo temporal. Pensar essas questões é, acima de tudo, encarar o tempo enquanto parâmetro conceitual, ou seja, enquanto variável a ser manipulada com o objetivo de implementar os conceitos e as interações desejadas. Nesse sentido, não há certo ou errado, o que existe é um amplo espectro de oportunidades a ser explorado, e que deve ser utilizado de forma apropriada, de acordo com as intenções do projeto.

O importante é tratar o tempo não apenas como algo linear e seqüencial, mas sim, como diversas dinâmicas paralelas, que podem influenciar e serem influenciadas umas pelas outras, bem como sobrepostas. Essa perspectiva é proposta, a partir do pressuposto, que os caminhos entre os inputs e os outputs, de um sistema interativo, podem ser muito mais complexos do que ações e reações imediatas e previsíveis. Uma das questões a serem abordadas é como essa interação se desdobra ao longo do tempo.

\title{
3.3.3 Interação
}

\author{
- Automático? Reativo? Interativo? Conversação? \\ - Quais são os modos possíveis de interação \\ viabilizados pelo sistema? \\ - Como os conceitos de interação se relacionam com \\ sua lógica interna e sua coerência externa?
}

Muito tem sido discutido sobre o conceito de interação, no que diz respeito às possibilidades da tecnologia digital. Mais importante que encontrar a definição perfeita do termo, ou ser capaz estruturar modos, a cada dia, mais avançados de interação, essas discussões devem ser encaradas como um meio de ampliar o conhecimento do que é possível. Assim, elas contribuem para deslocar o foco e evitar 
a simplificação das qualidades da interação, quando viabilizada por recursos computacionais.

Apesar do termo interação ser anterior à tecnologia digital, é importante entender suas particularidades. Acentua-se, nesse caso, o que ela oferece em termos de processos de comunicação e troca de informações entre partes - ou participantes - de um sistema. A interação enquanto parâmetro conceitual, para o design da arquitetura interativa, coloca em discussão essas questões e entendimentos. Assim, é importante, neste tipo de projeto, ter claro quais são os recursos disponíveis em termos de possibilidades interativas.

Glynn (2008), por exemplo, para compreender e desenvolver a prática de projetos interativos, descreve e diferencia três tipos de reações, a saber: automática, reativa e interativa. A automática descreve um sistema que é executado independente de estímulos externos, de forma que possui apenas dois estados, ligado e desligado. A reativa é aquela que possui uma série de estados pré-definidos, acionados de acordo com critérios estabelecidos de antemão.Essas reações, segundo o autor, são falsamente denominadas interativas.

A partir dessa perspectiva, a reação interativa, só pode ser considerada como tal, se certo grau de autonomia for implementado no sistema. Nesse caso, são estabelecidos objetivos a serem alcançados e, o sistema, desenvolve táticas para alcançá-los, por meio do improviso, do aprendizado e da negociação. Assim, o próprio algoritmo sofre modificações, de acordo com os padrões de estímulos recebidos.

A estratégia, descrita por Glynn (2008), é importante para entender possibilidades, porém seu conceito de interação é restrito, especificamente, ao tipo de algoritmo implementado no sistema. De forma complementar, a descrição proposta por Dubberly, Pangaro e Haque (2009), aborda diferentes tipos de interação, como resultado da troca entre dois sistemas. Para os autores, a interação não é característica do sistema em si, mas sim, da natureza da troca entre diversas entidades, de acordo com suas características particulares.

Somadas à essas descrições, a abordagem proposta por esta pesquisa adiciona duas perspectivas, que podem ser utilizadas para discutir possibilidades interativas, são elas: lógica interna e coerência externa. A lógica interna se assemelha com a abordagem de Glynn (2008), já que compreende os algoritmos implementados no sistema. A coerência externa expande a perspectiva de Dubberly, Pangaro e Haque 
(2009), ao incluir, como critério, o significado da interação a partir do contexto maior no qual ela se inscreve, bem como das intenções e modelos de mundo a partir dos quais os sistemas são concebidos e implementados.

De certa maneira, é a coerência externa do sistema que determina o quão apropriado é seu arranjo. É complicado se deter demasiadamente nessas definições, pois, grande parte das vezes, o resultado final inclui, não apenas um recurso interativo, mas sim, diversas soluções, sobrepostas e complementares. De sistemas automáticos até conversacionais, não existe certo ou errado. Mais do que uma qualidade, os diversos níveis de interação, viabilizados por recursos informacionais são recursos, que podem ser utilizados para transmitir diferentes significados e envolver as pessoas em interações com o espaço.

\subsubsection{Narrativas}

Qual é a história que a experiência interativa conta? Qual o papel dos participantes nesta narrativa? Qual a relação da narrativa, com outras histórias e referências do contexto?

Ponderar sobre narrativas, ou a partir de narrativas, está ligado, por um lado, com o caráter intrinsecamente temporal e seqüencial do comportamento da arquitetura interativa. Por outro, faz relação ao fato que, implícito na interatividade, está a relação com outros elementos com os quais estabelecem-se trocas de informação. São estes, os principais fatores, que fazem da narrativa um parâmetro relevante para o design deste tipo de espaço. Recursos narrativos, desta maneira, podem ser interpolados ao processo de design em diversas instâncias, como recurso expressivo para desenvolver e dar coerência ao projeto.

No geral, como aponta Lawson (2011), a criação de narrativas começa com a descrição da situação e dos personagens. Depois, esses personagens recebem personalidades, ou seja, características próprias. A natureza do caráter de cada um, bem como sua relevância para a história como um todo, passa também a ser examinada. Por fim, a trama é desenvolvida a partir da descrição relacionamento dos personagens, e, com isso, são desvendados onde ocorrem conflitos e oportunidades.

$\mathrm{Na}$ arquitetura interativa, a narrativa pode ser entendida como o recurso que amarra tanto as escolhas, quanto a manipulação dos outros parâmetros. Por um lado, ela é utilizada para visualizar e dar sustentação às projeções futuras. Isso é importante, 
especialmente no desenvolvimento da lógica interna, do comportamento do espaço, pois se relacionam, diretamente, com a elaboração dos algoritmos.

Os algoritmos são baseados no raciocínio lógico e temporal, caracterizado, entre outras, por declarações do tipo: "se essa condição for verdadeira, então aquilo acontece", ou também, "enquanto isso acontece, aquilo é disparado". Dessa maneira, as variáveis do sistema podem ser entendidas com os personagens dinâmicos da história, as regras (equações) são as situações que conectam os personagens ao contexto. Isso faz com que, de certa maneira, seja inevitável a utilização de recursos narrativos, pois falar sobre a arquitetura interativa não é apenas descrever sua forma, mas também como ela se comporta.

Por outro lado, em relação à coerência externa do espaço, é importante conectar sua narrativa com as outras de seu contexto. Deste modo, é interessante se dispor de coisas que já aconteceram, tais como memórias, percepções, fatos, analogias e metáforas, para a construção da narrativa própria do espaço. Assim, além da narrativa ser a linha condutora para a amarração dos outros parâmetros, determina também, a relação entre os participantes e suas próprias narrativas. De certa maneira, é ela quem fundamenta o discurso da interação.

\subsubsection{Feedback}

- Qual feedback as pessoas recebem ao interagir? - Como os participantes percebem que suas ações causaram impacto no sistema?

O parâmetro feedback, ou retroalimentação, para a arquitetura interativa, relaciona-se com a circularidade da relação entre o espaço e os participantes da interação. No que diz respeito ao design deste tipo de sistema, a discussão dos feedbacks engloba como e quando o espaço manifesta informações sobre seu estado. Essa questão torna-se relevante de ser incorporada, já que trata-se de uma arquitetura dinâmica, que pressupõe troca constante com seu contexto.

Uma vez que o sistema interativo da arquitetura é ativado, ele passa a esperar que coisas aconteçam, ou seja, que seus sensores sejam estimulados. Uma vez que novas informações são inseridas no sistema, elas são processadas e, dependendo do algoritmo implementado, podem ou não manifestar algum tipo de reação. Esse processo acontece inúmeras vezes por segundo, e é também denominado de iteração. O sistema itera a cada vez que verifica os sensores, processa e responde. Assim, o feedback diz respeito à natureza dessa resposta. 
Nesse caso, falar sobre feedbacks é estabelecer quais aspectos, resultantes das computações, são mostrados, como eles são materializados e qual é a intenção que guia essas questões. São diversos os papéis exercidos pelos feedbacks, por exemplo, eles podem confirmar que algo foi feito, comunicar resultados, bem como estimular ou desencorajar novas ações. Todas essas estratégias, fazem parte do conjunto de possibilidades e decisões que devem ser tomadas no design arquitetura interativa.

No geral, são distinguidos dois tipos de feedback, o positivo e o negativo. Em síntese, no feedback positivo, a relação é diretamente proporcional, ou seja, quanto mais estímulo, mais o sistema responde. Nesse caso, o estímulo inicial causa mais estímulos do mesmo tipo, o que torna o inverso também válido: quanto menos estímulo, menos o sistema responde. No feedback negativo, a relação é inversamente proporcional, de forma que quanto mais estímulo, menos o sistema responde, e vice-versa. As duas versões do feedback negativo são normalmente utilizadas em conjunto para manter o equilíbrio de sistemas, como ocorre, por exemplo com o termostato de uma casa. Essas definições são importantes para compreender possíveis estratégias de aplicação de feedbacks.

O feedback pode, assim, ser aplicado para diversos propósitos. Com o propósito informacional, por exemplo, ele cumpre o papel de apenas conscientizar as partes envolvidas de que o sistema está funcionando, de que as ações estão sendo incorporadas na computação. Com o propósito motivacional, o feedback pode instigar os participantes a desempenharem ações específicas, que podem geras outros padrões de comportamento no sistema.

Assim sendo, entender o feedback como parâmetro conceitual para o design da arquitetura interativa, significa projetar a manifestação do resultado, das ações das pessoas no sistema. Tal abordagem, inclui cogitar a relevância dessa informação para os participantes e de que maneira elas podem vir a estimular outros comportamentos por parte de quem interage com o espaço.

Essa sensação de impacto, estimulada pelos feedbacks, lida com a conscientização dos participantes, de que são agentes ativos na conformação do espaço e de seu comportamento. O projeto da interação, nesse sentido, deve incluir respostas às participações, o que faz dos recursos de feedback, aspectos importantes para sustentar esse envolvimento. 


\subsubsection{Tecnologia}

- Qual é o importância da tecnologia no projeto?

- Começa com conceitos e depois são acrescidos

recursos técnicos? Ou o conceito é uma exploração

direta da tecnologia?

- Como acontece essa negociação ao longo do processo?

No design da arquitetura interativa, a tecnologia em si não deve ser determinante. $O$ ideal é que a adição de sistemas interativos ao espaço seja conseqüência da exploração conceitual e das caracaterísticas que esses sistemas podem incorporar à dinâmica como um todo. Deste modo, a tecnologia é um dos parâmetros que precisam ser ponderados e equilibrados ao longo do processo.

Tratar a tecnologia como parâmetro, é entender sua situação flutuante ao longo do processo de design. Isso é importante pois, da mesma maneira que ela abre uma ampla gama de possibilidades, sua aplicação deslumbrada pode vir a limitar outros aspectos, também importantes para o projeto. Assim, a tecnologia deve ser encarada, em alguns momentos, com profundidade e, em outros, com distanciamento.

Em um extremo desse parâmetro, pode-se falar em um processo que visa a exploração de aspectos técnicos específicos. Por exemplo, o escopo dado para um certo projeto pode partir da exploração de recursos tecnológicos específicos, talvez pela facilidade de acesso à eles, por seu baixo custo, bem como por uma relação próxima dos clientes com determinada solução - caso eles sejam os desenvolvedores da tecnologia. Nesse caso, cabe aos arquiteto e designers, desenvolver um conceito coerente com o contexto, a partir da aplicação do que há disponível.

No outro extremo, encontra-se uma situação na qual não há restrições tecnológicas, e o escopo do projeto compreende, em especial, a exploração conceitual da idéia. Neste caso hipotético, a situação é específica, e o papel da tecnologia no processo de design passa a ser bem diferente. Aqui, são necessárias outras estratégias de processo para delimitar e explorar a relação entre conceito e tecnologia.

Entre esses dois extremos, encontra-se a alternância de diferentes momentos e intensidades, um espaço-entre o determinismo técnico e a exploração conceitual. Mesmo com o conceito já elaborado, em outro momento, a pesquisa de soluções técnicas pode retroalimentar o processo e impor algumas mudanças, tanto na própria 
idéia, quanto em outros aspectos do projeto. Além disso, por exemplo, pode ser necessária a explorações de alternativas técnicas, porém, de forma que não alterem o significado geral da proposta.

Enfim, o mais importante é compreender que, lidar com os aspectos tecnológicos na arquitetura interativa, implica nessa equalização constante. É importante ficar atento, para não insistir em soluções, talvez desnecessariamente, que restrinjam a percepção de outras possibilidades. O essencial do projeto, mais do que a tecnologia em si, é o conceito e seu impacto no contexto. Quando isso é trazido para primeiro plano, a idéia se mantém, mesmo que novas tecnologias apareçam diariamente. A interatividade, afinal, começa com as pessoas, e a tecnologia, no fundo, é (ou deveria ser) apenas uma ferramenta para mediar esse processo.

\subsubsection{Regras}

- Implícitas ou explícitas?

- Quanto a pessoa precisa saber para participar?

- Até que ponto, descobrir as regras, faz parte da interação?

- As regras mudam ou permanecem as mesmas?

No contexto aqui colocado, falar em regras significa abordar as diretrizes da participação na dinâmica interativa com o espaço. Deste modo, as regras definem o que acontece, quando e como o sistema funciona. Em alguns casos, elas são essenciais para orquestrar os diversos acontecimentos relevantes para a interação proposta. Relacionam-se diretamente com a lógica interna da arquitetura interativa, e definem como a interação dos diferentes participantes acontece.

Nesse sentido, não há um conjunto regras, ou uma formalização de como devem ser criadas, que se aplica a todos os casos. As regras podem ser, por exemplo, implícitas ou explícitas. As regras implícitas não são expressas em termos precisos, de forma que elas são subentendidas. Talvez, nesse caso, parte da experiência proposta seja justamente a sua descoberta, ou mesmo a elaboração de entendimentos subjetivos, de como o sistema funciona e o que deve ser feito.

Regras explícitas, ao contrário, são expostas de maneira clara, de modo a não deixar dúvidas. Essa estratégia é importante para contextos que não comportam ambigüidade, ou que uma eventual dúvida de como agir pode levar a conseqüências indesejáveis e desagradáveis. Por outro lado, de uma forma mais amena, o não 
entendimento, do que fazer e como agir, pode gerar um rápido desinteresse das pessoas pela obra e esta, de tão enigmática, torna-se frustrante.

As regras podem, também, ser abertas ou fechadas. Quando fechadas, elas não mudam, o que torna o comportamento sempre previsível, por mais que seja dinâmico. De forma mais específica, pode-se dizer que, uma vez determinados os algoritmos, as funções variam as execuções de acordo com os estímulos, porém a relação entre os valores é sempre fixa. De certa maneira, esse tipo de recurso torna a arquitetura mais prescritiva, o que pode ser interessante de ser explorado, em ocasiões específicas.

Quando as regras são abertas, há a possibilidade de alteração em sua estrutura. Isso pode acontecer, por exemplo, ao permitir que participantes alterem aspectos específicos da dinâmica, ou que construa novas regras. Isso dá a eles, mais influência sobre o conteúdo da interação, e permite que outras partes, além dos executores, exerçam influência significativa no resultado do projeto.

Falar em regras implícitas ou explícitas, abertas ou fechadas, é apenas uma estratégia possível para lidar com esse parâmetro. Essas questões podem ser implementadas nos projetos em diversos níveis e combinações. A própria possibilidade de mudança, em um nível, não deixa de ser uma regra, em outro. Um sistema pode ter regras implícitas e abertas, implícitas e explícitas em diferentes momentos, e assim pode diante.

Assim como os outros parâmetros, as regras apresentam um conjunto de possibilidades a serem ponderadas. Eventos paralelos acontecem em vários níveis e a decisão de quais momentos é interessante deixar as regras implícitas ou explícitas, assim como a relação dessas escolhas com sua abertura ou restrição, dependem da intenção do projeto. Trazer essas questões na forma de um parâmetro, é feito com o intuito de que esse processo de escolha, seja feito de maneira consciente.

\subsubsection{Engajamento}

- Como as pessoas são convidadas e estimuladas a participar?

- Qual é o incentivo para elas se manterem interessadas?

Falar em engajamento, entre outras conotações, pode significar, por um lado, o ato de atrair, seduzir e aliciar algo. Por outro, refere-se à ação de dedicar-se a alguma coisa, no sentido de se esforçar para que algo aconteça. No caso da arquitetura interativa esses dois significados podem balizar escolhas e ações em seu processo. Isso acontece, 
na medida em que, seus elementos podem desempenhar o papel de atratores, como também, sua apropriação pelos participantes pode ser engajadora.

Essas perspectivas aparecem com diversas relevância em diferentes momentos da interação. Pode-se assim, arriscar mencionar a existência de um ciclo de engajamento, aqui descritos em três momentos. O primeiro, é aquele em que se dá o convite à participação, ou seja, que são determinados os elementos que chamam a atenção das pessoas. É a primeira impressão e sinal que avisa a elas, que podem se envolver. Assim, no design da arquitetura interativa, é importante ponderar quais são as circunstâncias em que se torna necessário as pessoas entenderem que são convidadas a interagir com o espaço.

O segundo momento do ciclo, aqui proposto, tem a ver com os aspectos físicos do espaço que indicam, ou dão pista, das regras, ou seja, de como o participante pode ou deve interagir. Trata-se das regras pela arquitetura. Assim, elementos do próprio espaço podem ser atuantes em ajudar o participante a se deslocar pela interação. Novamente, faz parte do design, ponderar em quais momentos esse recurso deve ser implícito ou explícito.

O terceiro e último momento do ciclo, engloba a idéia de incentivo, ou seja, daquilo que mantém o participante ativo no engajamento. Parte desse momento, compreende ajudar as pessoas a entenderem o que podem extrair desse engajamento. Ao apresentar incentivos, é importante a atenção às ações dos participantes para a determinação das próximas reações.

Esse ciclo pode durar segundos, minutos ou dias. Pode ser interessante ou não, dependendo do contexto. De qualquer maneira, os dois primeiros momentos são, até certo ponto, mais controláveis ou passíveis de serem determinados, pois dependem mais de questões estruturais do espaço. O terceiro, depende da vontade, interesse e disposição da pessoa em participar. Porém, apesar de conter certa imprevisibilidade, há como, contribuir para que isso aconteça, oferecendo condições para que o engajamento acontecer, por mais que não haja garantia. Assim, o design da arquitetura interativa a partir do parâmetro engajamento, engloba equacionar como esses, e diversos outros níveis de engajamento são elaborados, ou seja, como são determinador em quais momentos contribuem com as intenções do projeto. 


\subsubsection{Imprevisibilidade}

- Quando se fala sobre o inesperado? Subversão?

- De que maneira é possível incorporar o nãodeterminado e projetar para um controle inexato?

- Em que momento do projeto, essa estratégia se torna relevante?

Lidar com o parâmetro da imprevisibilidade é incluir no processo, a abertura para a incorporação do não-determinado, do acaso e do controle inexato. É conseguir compreender em quais momentos esse aspecto pode vir a agregar coisas positivas ao projeto e, em quais outros, o ambiente deve ter um caráter mais prescritivo e determinante. Trata-se, acima de tudo, de balancear esses dois aspectos.

A imprevisibilidade, em um projeto, instiga a elaborar situações outras, que aquelas previsíveis e otimizadas. Não se trata de impor um modelo, o qual os participantes precisam aprender e se adaptar, e sim abrir espaço para que comportamentos não esperados possam ocorrer. Esse aspecto é bastante relevante, na arquitetura interativa, em especial quando o processo de design pressupõe grande ênfase nas pessoas enquanto participantes, a partir de suas especificidades.

Um exemplo de proposta com alto grau de imprevisibilidade, são os espaços criados como plataforma de experimentação, ou seja, como suporte para que outros conteúdos possam ser adicionados. Nesse caso, são disponibilizados alguns pontos de contato - elementos de transição - entre a estrutura e a intervenção, e a partir daí o que pode ser feito dependerá das circunstâncias futuras. Se o projeto depende dessa apropriação livre para se completar, um projeto rigoroso dessas estruturas de transição deve ser feito, levando em consideração outros aspectos contextuais, ou seja, características dos possíveis participantes.

Uma outra maneira de lidar com a imprevisibilidade, é incluir no discurso, o que pode ser feito caso as situações previstas nunca aconteçam. Pode-se, a partir daí elaborar estratégias alternativas que, aos poucos, possam influenciar nesse aspecto rumo a uma outra situação mais desejada. Esse parâmetro é extremamente relevante, uma vez que a arquitetura interativa, assim como outros aparatos tecnológicos, dependem da participação de partes não controláveis.

Acredita-se, assim, que a imprevisibilidade não deve ser encarada como um dado óbvio e inevitável. Pelo contrário, no design da arquitetura interativa, ela deve ser estrategicamente incorporada no processo, de forma a guiar diferentes ações e 
soluções. Assim, é sempre importante antecipar situações, na medida do possível que podem aparecer de repente e afetar o resultado do projeto, ou apenas criar espaço que isso seja incorporado. No geral, trata-se de incluir as múltiplas interpretações e apropriações como parâmetro de projeto. E permitir que os diferentes participantes exerçam, ali, sua autonomia. 


\section{Considerações finais}

Ao longo do desenvolvimento deste trabalho, nas diversas oportunidades que seu conteúdo foi apresentado ao público, algumas vezes, foi colocado em questão o termo interatividade. Nesses casos, a dúvida era sempre respaldada pelo pressuposto de que a interação não surgiu com a tecnologia digital, ao contrário, o ser humano é um ser naturalmente interativo. Interage o tempo inteiro com as pessoas, com o ambiente e com a natureza.

A resposta padrão a essa questão partia sempre da necessidade de recorte e definição de um objeto de pesquisa. Para esse trabalho, a arquitetura interativa é definida como aquela, viabilizada em alguma instância, por microchips que admitem a implementação de raciocínios lógicos em seu núcleo controlador, somados aos elementos e componentes responsáveis pela entrada e saída de dados do sistema. Da mesma forma, a interação considerada por seu escopo é aquela que também pressupõe a presença desses sistemas. Apesar de modos de interação existirem, não fazem parte dessa investigação. Assim, ao longo dos quatro anos de desenvolvimento deste estudo, essa definição foi fundamental para a manutenção de sua continuidade.

Todas as investigações realizadas, que serviram de base para a construção das discussões colocadas ao longo desta tese, foram feitas em função da adoção desse pressuposto. Quando oportunidades não planejadas apareceram, a primeira consideração a ser feita era em relação à sua contribuição para o objeto de investigação. Caso fosse viável e contribuísse de algum modo para a expansão de seu entendimento, as etapas de trabalho eram rearranjadas para incluir essas novas investigações.

Notou-se, assim, que a aproximação com a tecnologia traz novas temas para a arquitetura em incontáveis níveis. Isso foi percebido, especialmente, após a realização das entrevistas e visitas. O grupo de entrevistados foi determinado, dentre outras coisas, por aparentarem possuir práticas semelhantes. No entanto, após conversar com profissionais e professores, a sensação foi que existem tantos tipos de prática de 
arquitetura interativa quanto existem pessoas fazendo e pensando sobre esse tipo de projeto.

Mesmo diante destas múltiplas possibilidades, manteve-se o desafio de delinear o que é a arquitetura interativa e, além disso, propor estratégias para seu projeto. Contudo, para incluir a tecnologia digital, no discurso da arquitetura, foi necessário compreender criticamente, nuances do contexto maior do qual faz parte. Foi essa a intenção que originou o Primeiro Capítulo desta tese.

Essa delineação dos contextos foi feita com a consciência de que os tópicos tratados apenas introduzem questões e que, de forma alguma, essas questões foram esgotadas. Inúmeros outros ainda poderiam ser incluídos, assim como esses mesmos poderiam ser abordados por pontos de vista alternativos aos colocados. Ainda falta muito para completar essa trama que pretensiosamente é chamada de realidade. Assim, os contextos abordados foram aqueles encarados como essenciais para a construção do discurso dessa tese.

Nesse sentido, o principal objetivo do contexto ideológico foi desvendar alguns valores e visões de mundo que são reproduzidos inconscientemente, em especial, aqueles relacionados à tecnologia e ao progresso. O contexto tecnológico aborda fragmentos da história do desenvolvimento dos sistemas digitais de informação e comunicação, assim, como as especificidades desse tipo de tecnologia, a partir de um ponto de vista não-determinista. O contexto sócio-urbano explora a manifestação dos paradoxos do paradigma técnico, quando encontra a complexidade da vida real.

Quando analisados individualmente, cada um desses contextos coloca questões muito específicas. Porém, quando percebidos como parte de uma realidade maior, fica claro como são intensamente interrelacionados. Essa teia interconectada de contextos engloba, também, a arquitetura interativa que, apesar de possuir suas especificidades, não deve ser pensada à parte desse contexto maior.

Assim, incluir a tecnologia no discurso da arquitetura é, antes de tudo, compreender criticamente o mundo em que vivemos. É, ao mesmo tempo, encantar-se e desconfiar das possibilidades. É expandir o campo do conhecimento e lidar com os paradoxos intrínsecos ao ato de conhecer. É encontrar espaço na racionalidade científica, na lógica matemática, para tentar incluir, conscientemente, valores, moral e subjetividade. 
Apenas após esse primeiro movimento, foi possível colocar o espectro próprio da arquitetura interativa. Em primeiro lugar, deve estar claro que ela é resultado de uma relação muito mais ampla entre a arquitetura e a tecnologia. Porém, no caso do objeto estudado, trata-se, especificamente, da tecnologia digital inserida ao produto final arquitetônico. Para explicar a constituição desse espaço, foram propostas duas perspectivas paralelas que devem, assim como acontece com os contextos, ser entendidas como simultaneamente diferentes e complementares.

Estrutura e comportamento. Acredita-se que essa dupla abordagem consegue definir o que é a arquitetura interativa, e como ela se difere do que não é arquitetura interativa. Estruturalmente, essa arquitetura deve conter algum tipo de processamento de informação digital e, consequentemente, elementos que captem ou reproduzam a informação processada. Exatamente como isso é feito e implementado varia enormemente, de acordo com o projeto, recursos e tecnologia disponível.

Comportamentalmente, uma vez que essa arquitetura contém processamento de informação, consequentemente, ela possui algum nível de raciocínio, implementado por sistemas digitais. Porém, falar desse algoritmo, ou seja, dessa lógica interna é insuficiente para compreender a arquitetura interativa. Por mais que algoritmos não aceitem ambigüidade, a definição de seus parâmetros são totalmente subjetivos. Eles representam o entendimento maior dessa arquitetura por quem a projeta. Nesse sentido, a coerência externa inclui visões de mundo, e o papel daquela arquitetura nesse contexto maior. Implícita ou explicitamente é, a partir dessas perspectivas, que a especificidade do algoritmo é elaborada.

As características e os contextos com os quais a arquitetura interativa dialoga foram, inicialmente, elaborados como base para abordar a principal questão da pesquisa. Se a arquitetura interativa é o objeto de estudo, seu objetivo principal é entender como ela pode ser projetada. As investigações feitas partiram da inquietação frente às, proclamadas, novas maneiras de projetar, viabilizadas por softwares de modelagem espacial e fabricação digital. No caso desta pesquisa, partiu-se do pressuposto de que, para projetar espaços adaptáveis e interativos não basta utilizar algoritmos para gerar sua forma ou mesmo luzes e movimento para torná-los dinâmicos. É preciso, também, trazer questões relacionadas ao seu uso e sua apropriação pelas pessoas.

Nesse contexto, a principal contribuição dessa pesquisa é a proposição de parâmetros conceituais para serem manipulados, durante o projeto desse tipo de arquitetura. Sua elaboração foi resultado de uma abordagem múltipla que combinou desenvolvimento 
de projetos, estágios, entrevistas, conversas com profissionais de outras áreas, dinâmicas colaborativas e intensa revisão bibliográfica. Dentre outras utilidades, a função desses parâmetros é ampliar o vocabulário e os modos de trabalho da arquitetura como um todo, já que a arquitetura interativa faz parte desse contexto maior.

De modo geral, a aproximação, aqui realizada, foi um meio de explorar e entender um pouco mais o mundo tecnológico em que vivemos. Assim, a motivação de compreender o que é necessário para projetar a arquitetura interativa, ou seja, para incluir a tecnologia em seu produto, pressupõe discussões capazes de expandir o campo da arquitetura. Inclui, nele, a possibilidade e necessidade de que arquitetos atuem, além de consumidores dessa tecnologia, também como protagonistas ativos em sua conformação.

A análise, aqui empreendida, em nenhum momento dedicou-se a esgotar o tema. Mais do que tudo, a intenção é abrir caminho para discussões engajadas sobre o papel da tecnologia, no cotidiano e na prática da arquitetura. Uma das principais dificuldades ao escrever o texto foi delimitar sua abrangência. Por conseguinte, cada item e subitem desta tese pode, facilmente, ser desdobrado em outras pesquisas específicas, já que possuem diversas questões encapsuladas.

Por fim, escrever as considerações finais de uma pesquisa é sempre admitir que se iniciasse agora, tudo seria diferente. A tese é o congelamento de um movimento do pensamento, de forma que o próprio ato de escrever traz, em si, novas questões. A sensação que fica, mais uma vez, é a de que o trabalho está apenas começando. Apesar disso, acredita-se que as discussões, aqui colocadas, são extremamente relevantes para o entendimento e apropriação fundamentada da tecnologia.

Ao final desse processo, é necessário concordar que a interatividade realmente não pressupõe a tecnologia digital e que, muitas vezes, esses recursos são desnecessários e sua aplicação duvidosa. Mesmo assim, acredita-se que as questões colocadas por esta tese, sobrevivam, mesmo que todos os recursos digitais sejam retirados do espaço. De certa forma, uma vez que o arquiteto aprende, na prática, sobre a manipulação desses parâmetros e conceitos, por mais que ele não utilize recursos tecnológicos, os fundamentos aprendidos podem, mesmo assim, manter-se e influenciar seu modo de perceber e de se colocar no mundo. Assim sendo, talvez a arquitetura interativa relacione-se mais com um modo especial de entender e abordar a produção da arquitetura do que um tipo específico de construção. 


\section{Referências bibliográficas}

AALEN, Carlos Alarcon. Projeto Low2No. Entrevista concedida a Gabriela Carneiro. Berlim: Acervo pessoal, 12 abr. 2011.

ARUP; SAUERBRUCH HUTTON; EXPERIENTIA. C_Life: Strategy Manual. 2009. Disponível em: <http://www.low2no.org/downloads/Low2No\%20Manual\%20Arup.pdf>. Acesso em: 30 jan. 2014. . Informatics Workbook. Sep, 2010a. Disponível em: <http://low2no.org/downloads/Low2No_Informatics_Workbook_v2.pdf> Acesso em: 30 jan. 2014.

. Enabling Sustainable Lifestyles: Low2No Concepts. Low2No project report, phase 2. Nov, 2010b.

ABBAGNANO, Nicola. Dicionário de Filosofia. São Paulo: Martins Santos, 2012.

ADDINGTON, Michelle; SCHODEK, Daniel. Smart Materials and New Technologies for Architecture and Design Professions. Oxford: Architectural Press, 2005.

ALCORN, Paul. Social Issues in Technology: A Format for Investigaton. Englewood Cliffs, NJ: Prentice-Hall, 1986.

ALEXANDER, Christopher. Notes on the Synthesis of Form. Cambridge. MA: Harvard University Press, 1964 . Systems Generating Systems. 1968. In: MENGES, Achim; AHLQUIST, Sean (Ed.). Computational Design Thinking. London: John Wiley \& Sons, 2011. p. 58-68.

. A Refutation of Design Methodology (Interview with Max Jacobson). Architectural Design, 42, Dec. 1971.

ARAYA, Augustin. Questioning Ubiquitous Computing. IN: CONFERENCE ON COMPUTER SCIENCE - ACM, 1995. Proceedings... New York: ACM, 1995. p. 230237. 
BARROS, Gil; CARNEIRO, Gabriela (2013) . A technique to improve sketches of rich interactions. In: BRAZILIAN SYMPOSIUM ON HUMAN FACTORS IN COMPUTER SYSTEMS - IHC, 13., 2013, Manaus. Proceedings... Manaus, 2013. p. 22-31.

BAZJANAC, Vladimir. Architectural Design Theory: Models of the Design Process. In: Spillers, William (Ed.). Basic Questions of Design Theory. Amsterdam: NorthHolland Publishing Company, 1974.

BIER, Henriette; KNIGHT, Terry. Digitally-Driven Architecture. Footprint Online Journal, ed. 6, p. 1-4, Spring, 2010.

BENIGER, James. The Control Revolution: Technological and Economic Origins of the Information Society. Cambridge, MA: Harvard University Press, 1986.

BATESON, Gregory. Mente e Natureza. Rio de Janeiro: Livraria Francisco Alves Editora, 1986.

BRAUN, Ernst; MACDONALD, Stuart. Revolution in Miniature: the history and impact of semiconductor electronics. Cambrigde, MA: Cambridge University Press, 1982.

BRIGGS, Asa; BURKE, Peter. Uma história social da mídia: de Gutenberg à Internet. Rio de Janeiro: Jorge Zahar Ed., 2004.

BROADBENT, Geofrey. Design in Architecture: Architecture and the Human Sciences. London: David Fulton Publishers, 1988.

BROWN, John Seely; DUGUID, Paul. A vida social da informacão. São Paulo: Makron Books, 2001.

BURRY, Mark (2003). Between Intuition and Process: parametric design and rapid prototyping. In: KOLAREVIC, Branko (ed). Architecture in the Digital Age: Design and Manufacture. London: Taylor \& Francis, 2003. p. 147-162.

BURY, John Bagnell. The Idea of Progress. London: Macmillan and Co, 1921.

CARA, Milene. Do desenho industrial ao design no Brasil: uma bibliografia crítica para a disciplina. São Paulo: Blucher, 2010.

CARNEIRO, Gabriela. Objetos interativos: design e tecnologias da informação e comunicação. Dissertação (Mestrado em Arquitetura e Urbanismo) - Instituto de Arquitetura e Urbanismo, Universidade de São Paulo: São Carlos, 2008. ; BARROS, Gil; COSTA, Carlos Zibel (2010). Objetos interativos em contexto: estrutura, análise e representação de objetos interativos. In: CONGRESSO BRASILEIRO DE PESQUISA E DESENVOLVIMENTO EM DEISGN, P\&D, 9., 2010, São Paulo. Anais... São Paulo: Blücher e Universidade Anhembi Morumbi. ; LI, Julie (2011). i | o Cards: A Tool to Support Collaborative Design of Interactive Objects. In: INTERNATIONAL CONFERENCE ON CREATIVITY AND INNOVATION IN DESIGN, 2., 2011, Eindhoven, Holanda. Proceedings... New York: ACM, p.357-358. 
; SPINOLA, Diego; REQUENA, Guto; COSTA, Carlos Zibel. The Study of a Design Process Intended for Interactive Environments. In: CONFERÊNCIA LATINO AMERICANA DE DESIGN DE INTERAÇÃO, 3., INTERACION SOUTH AMERICA, 2011, Belo Horizonte, UNI-BH. Anais... Belo Horizonte: IxDA-BH, 2011, p.233239. Disponível em:

<http://issuu.com/interactionsouthamerica/docs/isa11_anais>. Acesso em: 03 fev. 2014.

; BARROS, Gil; COSTA, Carlos Zibel. Design colaborativo de comportamentos para ambientes interativos. Revista V!RUS, n. 6, dez. 2011. Disponível em: <http://www.nomads.usp.br/virus/virus06/?sec=4\&item=8\&lang=pt>. Acesso em: 03 fev. 2014.

; BARROS, Gil; COSTA, Carlos Zibel (2012). i|o Cards: A Tool to Support the Design of Interactive Artifacts. In: DESIGN RESEARCH SOCIETY INTERNATIONAL CONFERENCE, 2012, Bangkok, Thailand. Proceedings... Bangkok: Department of Industrial Design, Faculty of Architecture, Chulalongkorn University, 2012. v. 1, p. 213-226.

CASTELLS, Manuel. A Galáxia da Internet: Reflexões sobre a internet, os negócios e a sociedade. Rio de Janeiro: Jorge Zahar, 2003.

CELANI, Gabriela. CAD criativo. Rio de Janeiro: Editora Campus, 2003.

CHAUI, Marilena. Convite à Filosofia. São Paulo: Editora Ática, 2012.

COELHO, Marcelo. Materials of Interaction: Responsive Materials in the Design of Transformable Interactive Surfaces. 2008. Thesis (Master of Science and Technology) - MIT Media Lab, Cambridge, USA, 2008.

COTTON, Bob; OLIVER, Richard. Understanding Media: from Multimedia to Virtual Reality. London: Phaidon Press, 1994.

COUCHOT, Edmond. A tecnologia na arte: da fotográfica à realidade virtual. Porto Alegre: Editora da UFRGS, 2003.

DIZARD, Winston Jr. The Coming Information Age: an overview of technology, economics, and politics. London: Longman Inc, 1989.

DIX, Alan; GONGORA, Layda. Externalization and Design. In: INTERNATIONAL CONFERENCE ON CREATIVITY AND INNOVATION IN DESIGN, 2., 2011, Eindhoven, Holanda. Proceedings... New York: ACM, 2011. p.31-42.

DOURISH, Paul. Where the action is: the foundations of embodied interaction. Cambridge, MA: The MIT Press, 2004a.

. What we talk about when we talk about context. Journal of Personal \& Ubiquitous Computing, 8(1), 2004b. p.19-30.

DUBBERLY, Hugh. How do you design? A Compendium of Models. San Francisco, CA: Dubberly Design Office, 2004. 
; PANGARO, Paul; HAQUE, Usman. What is Interaction? Are there Different Types?. Interactions Magazine. ACM, Jan-Feb, 2009.

DUPAS, Gilberto. Ética e Poder na Sociedade da Informação: De como a autonomia das novas tecnologias obriga a rever o mito do progresso. São Paulo: Editora UNESP, 2000.

EDLER, Tim (2011). Mídia Fachadas: processos de design. Entrevista concedida a Gabriela Carneiro. Berlim: 09 Jun. 2011.

ELLUL, Jacques. A Técnica e o Desafio do Século. Rio de Janeiro: Editora Paz e Terra, 1968.

ENGELBART. Augmenting Human Intellect: A Conceptual Framework. 1962. In: PACKER, Randall; JORDAN, Ken (Ed.). multiMEDIA: from Wagner to Virtual Reality. London: W.W. Norton \& Company, 2002. p. 64-90.

FEENBERG, Andrew (2013). Tecnologia e finitude humana. 2013. TRABALHO APRESENTADO NO COLÓQUIO SOBRE A FILOSOFIA DA TECNOLOGIA DE ANDREW FEENBERG: DEMOCRACIA, RACIONALIDADE E INVENÇÃO, Uberlândia, MG, Universidade Federal de Uberlândia, 10-13 jun. 2013. Não Publicado.

FERRANTE, Isabela. Entre a arquitetura experimental e a arquitetura para a experiência: Máquinas, corpos e próteses de Lars Spuybroek/NOX. Dissertação (Mestrado em Arquitetura e Urbanismo) Faculdade de Arquitetura e Urbanismo, Universidade de São Paulo: São Paulo, 2013.

FERREIRA, Aurélio Buarque de Holanda. Dicionário Aurélio da língua portuguesa. Curitiba: Positivo, 2010.

FORESTER, Tom. The High-Tech Society. Cambridge, MA: The MIT Press, 1987.

FOX, Michael (2009). Redesigning the Brick. In: INTERNATIONAL CONFERENCE ON COMPUTER AIDED ARCHITECTURAL DESIGN RESEARCH IN ASIA, 14., Yunlin, Taiwan, 22-25 Apr. 2009. Proceedings... Yunlin, Taiwan, 2009. p. 381-390. ; KEMP, Miles. Interactive Architecture. New York: Princeton Architectural Press, 2009.

FRAZER, John. An Evolutionary Architecture. Architectural Association, London, 1995.

GAGE, Stephen. Interactivity and architecture. Entrevista concedida a Gabriela Carneiro. Londres: 10 Out, 2011.

GALLOWAY, Alexander. Protocol: how control exists after descentralization. Cambridge, MA: MIT Press, 2004.

; THACKER, Eugene. The exploit: a theory of networks. London: University of Minesota Press, 2007.

GLYNN, Ruairi. Conversational Environments Revisited. In: MEETING OF CYBERNETICS \& SYSTEMS RESEARCH, 19., Graz, Austria, 2008. Proceedings... Graz, Austria, 2008. 
; SHAFIEI, Sara. Digital Architecture: Passages Through Hinterlands. London: BPR Publishers, 2009.

- Arte e robótica: processos de design. Entrevista concedida a Gabriela Carneiro. Londres: 10 Out, 2011.

GRAHAM, Stephen; MARVIN, Simon. Splintering Urbanism: Networked Infrastructures, Technological Mobilities and the Urban Condition. London: Routledge, 2001.

GREENFIELD, Adam. Everyware: the dawning age of ubiquitous computing. Berkeley, CA: New Riders, 2006.

. Against the Smart City. E-pub: Do projects, 2013.

HAEUSLER, Matthias. Media Facades: History, Technology, Content. Ludwigburg, Germany: Avedition, 2009.

HAQUE, Usman (2007). The architectural relevance of Gordon Pask. Architectural Design - Special Issue: 4d Social - Interactive Design Environments, vol. 77, issue 4, p. 54-61, Jul./Aug. 2007.

HEATH, Tom. Method in Architecture. New York: John Wiley \& Sons, 1984.

HORKHEIMER, Max. Eclipse da Razão. Rio de Janeiro: Editorial Labor do Brasil, 1976.

IDEO. IDEO Method Cards: 51 ways to inspire design. San Francisco: William South Architectural Books, 2002.

IGOE, Tom. Making things talk. Canada: O'Reilley Media, 2007.

ISHII, Hiroshi; ULLMER, Brygg (1997). Tangible Bits: Towards Seamless Interfaces between People, Bits and Atoms. HUMAN FACTORS IN COMPUTING SYSTEMS CONFERENCE, CHI, 1997, Los Angeles. Proceedings... Los Angeles, CA: March 22-27, 1997.

IWAMOTO, Lisa. Digital fabrications: Architectural and Material Techniques. New York: Princetown Architectural Press, 2009.

JONES, John Chris. Design Methods. London: David Fulton Publishers, 1980.

KOLAREVIC, Branko (Ed.). Architecture in the Digital Age: Design and Manufacture. London: Taylor \& Francis, 2009.

KOLKO, John. Thoughts on Interaction Design. Burlington, MA: Morgan Kaufmann, 2009.

LANG, Jon; BURNETTE, Charles; MOLESKI, Walter; VACHON, David (eds.). Designing for

Human Behavior: Architecture and Behavioral Sciences. Stroudsburg, PE: Dowden, Hutchinson \& Ross Inc., 1974.

LAWSON, Bryan. Como arquitetos e designers pensam? São Paulo: Oficina de Textos, 2011.

LEA, Doug. Christopher Alexander: An Introduction for Object-Oriented Designers. 1994. Disponível em: 
<http://www.patternlanguage.com/leveltwo/caframe.htm?/leveltwo/../bios/d ouglea.ht>. Acesso em: 04 maio 2012.

LEMOS, André. Mobile Communication and New Sense of Places: a Critique of Spatialization in Cyberculture. Revista Galáxia, n. 16, São Paulo, 2007. p.91108.

. Mídia Locativa e Território Informacional. In: SANTAELLA, Lucia; ARANTES, Pricila (Ed.). Estéticas Tecnológicas: Novos Modos de Sentir. São Paulo: Ed. EDUC, 2008.

LICKLIDER, Joseph Carl Robnett. Man-Computer Symbiosis. 1968. In: Digital Equipment Corporation Systems Research Center. Memoriam: J. C. R. Licklider 1915-1990. Research Report 61. Aug. 1990. Disponível em: <http://memex.org/licklider.pdf>. Acesso em: 02 Feb. 2011. (Reimpressão)

LICKLIDER, Joseph Carl Robnett; TAYLOR, Robert. The computer as a Communication Device. 1968. Do original Science and Technology, April 1968. In: In: Digital Equipment Corporation Systems Research Center. Memoriam: J. C. R. Licklider 1915-1990. Research Report 61. Aug. 1990. Disponível em: <http://memex.org/licklider.pdf>. Acesso em: 02 Feb. 2011. (Reimpressão)

MARCONDES FILHO, Ciro. Ideologia. São Paulo: Global Editora e Distribuidora, 1968.

MATHEWS, Stanley. From Agit-Prop to Free Space: The Architecture of Cedric Price. London: Black Dog Publishing LimitEd, 2007.

McCULLOUGH, Malcolm. Digital ground: architecture, pervasive computing and environmental knowing. Cambridge, MA: MIT Press, 2004.

MENGES, Achim; AHLQUIST, Sean (Ed.). Computational Design Thinking. London: John Wiley \& Sons, 2011.

MITCHEL, Melanie. Complexity a guided tour. New York: Oxford University Press, Inc, 2009.

MITCHELL, William. The Design Studio of the Future. 1990. In: McCULLOUGH, Malcolm; MITCHELL, William; PURCELL, Patrick (Eds.). The electronic Design Studio: Architectural Knowledge and Media in the Computer Era. Cambrigde, MA: The MIT Press, 2009. p.479-494.

MOGGRIDGE, Bill. Designing interactions. Cambridge, MA: The MIT Press, 2007.

MONGIAT, Melissa; SNOOK, Kelsey. Exchange Pieces: Tools and Strategies for Engagement In Design. In: INCLUDE: DESIGNING WITH PEOPLE, 2007. Proceedings... Disponível em <http://www.hhc.rca.ac.uk/kt/include/2007/proceedings/paper.php?ID=1_149 $>$, Acesso em: 13 Jan. 2011.

MOREL-JOURNEL, Guillemette. Le Corbusier's Villa Savoye. Paris: Centre de Monuments Nationaux / Éditions du patrimoine, 2000. 
MURRAY, Jannet. Hamlet no Holodeck: o futuro da narrativa no ciberespaço. São Paulo: Itaú Cultural: Unesp, 2003.

NEGROPONTE, Nicholas. The Architecture Machine. Cambridge, MA: MIT Press, 1970. . Soft Architecture Machines. Cambridge, MA: MIT Press, 1975.

O'SULLIVAN, Dan; IGOE, Tom. Physical Computing: sensing and controlling the physical world with computers. Boston: Thomson, 2005.

OUNGRINIS, Konstantinos-Alketas. "Sensponding" Architecture: Towards a Holistic Approach to Transformable Design. In: TECTONICS MAKING MEANING, 2007, Eindhoven. Proceedings... Eindhoven: Netherlands University of Technology, 2007. Disponível em: <http://www.stud.tue.nl/ cheops/tectonics/Papers.htm>. Acesso em: 19 Maio 2012.

PACKER, Randall; JORDAN, Ken (Ed.). multiMEDIA: from Wagner to Virtual Reality. London: W.W. Norton \& Company, 2002.

PASK, Gordon. The Architectural Relevance of Cybernetics. 1969. In: MENGES, Achim; AHLQUIST, Sean (Eds.). Computational Design Thinking. London: John Wiley \& Sons, 2011, p.78-85.

. A Comment, a Case History and a Plan. 1970. In: REICHARDT, Jasia (Ed.). Cybernetic Art and Ideas. London: Studio Vista, 1971. p. 76-99. Reimpressão.

PAVONI, Edson. Avaliação do Ambiente Interativo D3. Entrevista concedida à Gabriela Carneiro. São Paulo, 10 ago. 2013.

PERNER-WILSON, Hannah. A Kit-of-No-Parts. Thesis (Master of Science) - MIT Media Lab. Cambridge, USA, 2011.

POSLAD, Stefan. Ubiquitous Computing: Smart devices, Environments and Interactions. Chichester, UK: John Wiley \& Sons Ltd, 2009.

POSTMAN, Neil. Tecnopólio: A Rendição da Cultura à Tecnologia. São Paulo: Nobel, 1994.

RHEINGOLD, Howard. Virtual Reality. New York: Summit Books, 1991.

ROCHA, Altin João De Magalhães (2004). Architecture Theory 1960-1980. Emergence of a Computational Perspective. PhD diss., Massachusetts Institute of Technology.

SAFFER, Dan. Designing for Interacion: Creative Innovative Applications and Devices. Berkeley, CA: New Riders, 2007.

SANTAELLA, Lúcia (2008). Mídias Locativas: a internet móvel de lugares e coisas. Revista FAMECOS, Porto Alegre, n. 35, Abr. 2008, p. 95-101.

SANTOS, Boaventura de Souza. Um discurso sobre as ciências. Porto: Edições Afrontamento, 1987. 
. Renovar a Teoria Crítica e Reinventar a Emancipação Social. São Paulo:

Boitempo Editorial, 2007.

SANTOS, Milton (2002a). A natureza do espaço. São Paulo: EDUSP.

SAUTER, Joachim. Espaços e Inteações. Entrevista concedida a Gabriela Carneiro.

Berlim: 30 Maio, 2011.

SCHOLZ, Trebor. Your Mobility for Sale. In: SHEPARD, Mark (Ed.). Sentient City:

Ubiquitous Computing, Architecture and the Future of Urban Space.

Cambridge, MA: The MIT Press, 2011. p. 204-211.

SCHWARTZ, Eugene. A Inflação da Técnica: O Declínio da Tecnologia na Civilização Moderna. São Paulo: Melhoramentos, 1971.

SHARP, Helen; ROGERS, Yvonne; PREECE, Jenny. Interaction design: beyond humancomputer interaction. 2a Ed. England: John Wiley \& Sons, 2007.

SHEPARD, Mark (Ed.). Sentient City: Ubiquitous Computing, Architecture and the Future of Urban Space. Cambridge, MA: The MIT Press, 2011.

SMITH, Gilliam Crampton. What is interaction design? In: MOGGRIDGE, Bill. Designing interactions. Cambridge, MA: The MIT Press, 2007. p. vii-xx.

SPILLERS, William (Ed.). Basic Questions of Design Theory. Amsterdam: North-Holland Publishing Company, 1974.

TALUKDER, Asoke; YAVAGAL, Roopa. Mobile Computing: Technology, Applications and Service Creation. New York: McGraw-Hill, 2007.

TERZIDIS, Kostas. Algorithmic Form. 2003. In: MENGES, Achim; AHLQUIST, Sean (Eds.).

Computational Design Thinking. London: John Wiley \& Sons, 2011. p.94-101.

THOMPSON, Richard Jr. Crystal Clear: The Strugle for Reliable Communications

Technology in World War II. Hoboken, NJ: John wiley \& Sons, 2007.

TURING, Alan. Computing Machinery and Intelligence. 1950. In: WARDRIP-FRUIN, Noah; MONTFORT, Nick (Ed.). The new media reader. Cambridge, MA: The MIT Press, 2003. p. 49-64.

VAHID, Frank; GIVARDIS, Tony. Embedded System Design: A Unified Hardware/Software Introduction. London: John Wiley \& Sons, 2002.

VALLGARDA, Anna; REDSTROM, Johan. Computational Composites. In: SIGCHI CONFERENCE ON HUMAN FACTOR IN COMPUTING SYSTEMS, 2007, San Jose, CA. Proceedings... New York: ACM, 2007.

VASSÃO, Caio. Arquitetura livre: Complexidade, Metadesign e Ciência Nômade. Tese (Doutorado em Arquitetura e Urbanismo) - Faculdade de Arquitetura e Urbanismo, Universidade de São Paulo, 2008.

YIANNOUDES, Sokratis (2010). Kinetic Digitally-Driven Architectural Structures as

'Marginal' Objects - a Conceptual Framework. Footprint Online Journal: Digitally-Driven Architecture, ed. 6, Spring 2010. pp. 41-54. 
WERTHEIM, Margaret (2001). Uma História do Espaço: de Dante à Internet. Rio de Janeiro: Jorge Zahar Ed, 2001.

WINSTON, Brian (2000). Media Technology \& Society: a History from the Telegraph to the Internet. London: Taylor \& Francis, 2000.

WEISER, Mark. The computer for the 21st century. In: Scientific American, 265, 1991. p.66-75.

ZIZEK, Slavoj. Vivendo no Fim dos Tempos. São Paulo: Editora Boitempo, 2012.

ZOELS, Jan-Christoph. Interaction Design and Architecture. Entrevista concedida a Gabriela Carneiro. Berlim: 28 Mar. 2011.

ZUK, William; CLARK, Roger. Kinetic Genesis. In: REINHOLD, Van Nostrand (ed.). Kinetic Architecture. Van Nostrand Reinhold, New York, 1970. p. 14-21. 